\title{
THE HYDROLOGICAL EFFECTS OF FIRE IN SOUTH AFRICAN CATCHMENTS
}

David Findlay Scott

Submitted in partial fulfilment of the requirements for the degree of

doctor of philosophy

in the Department of Agricultural Engineering

Faculty of Science

University of Natal

Pietermaritzburg

Stellenbosch

January 1994 


\section{ABSTRACT}

Stream-flow and storm-flow in four small catchments were analysed by the paired catchment method for a response to fire. Two of the catchments were vegetated with over-mature fynbos (the indigenous scrub vegetation of the south-western Cape Province, South Africa), one was afforested to Pinus radiata and the fourth to Eucalyptus fastigata. One of the fynbos catchments was burned in a prescribed fire in the late dry season. The other catchments burned in wildfires.

Neither of the fynbos catchments showed a change in storm-flows. Annual total flow increases of around $16 \%$ were in line with predictions, being related to the reductions in transpiration and interception. The manner of stream-flow and storm-flow generation appeared to have remained unaltered despite the fire.

The two timber plantation catchments experienced large and significant increases in stormflow and sediment yields, while total flow increased by $12 \%$ in the pine catchment and decreased marginally in the eucalypt catchment. After fire, storm hydrographs were higher and steeper though their duration was little changed. These fire effects are considered to be due to changes in storm-flow generation consistent with an increased delivery of overland flow to the stream channel. This was caused, in part, by reduced infiltration resulting from water repellency in the soils of the burned catchments.

The inherent wettability of a wide range of soil types and textures from beneath timber plantations and other vegetation types over a broad geographic distribution in South Africa was measured by four methods. Soils with high repellency ratings, unrelated to fire, are common and are most likely to occur beneath plantations of Eucalyptus and Acacia spp. and indigenous forest

Water repellent soils played a role, at two of the three locations, in the generation of overland flow from small plots exposed to simulated rainfall. However, the inherent repellency of the dry soils was extreme, such that fire-induced water repellency was not a factor in the response of the plots. The important role of fire in this experiment was in burning-off of repellency in the surface layer of the soil and in removing ground cover. 


\section{PREFACE}

The experimental work for this thesis was carried out in the experimental catchments of the Jonkershoek Forestry Research Centre near Stellenbosch and the Ntabamhlope research catchments near Estcourt, at field sites near Richmond and Mid-Illovo, Natal, and in the laboratories of the Jonkershoek Forestry Research Centre and the Departments of Agricultural Engineering and Agronomy of the University of Natal, Pietermaritzburg, under the supervision of Professor Roland E. Schulze.

These studies represent my own original research and have not previously been submitted in any form for any degree or diploma to any University. Where use has been made of the work of others this is specifically acknowledged in the text. 


\section{TABLE OF CONTENTS}

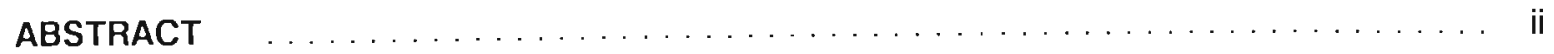

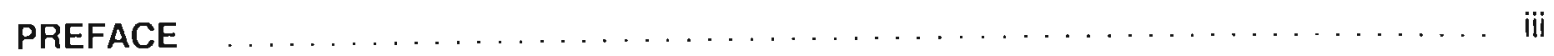

TABLE OF CONTENTS $\ldots \ldots \ldots \ldots \ldots \ldots \ldots \ldots \ldots$

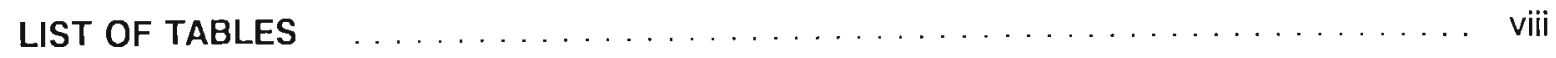

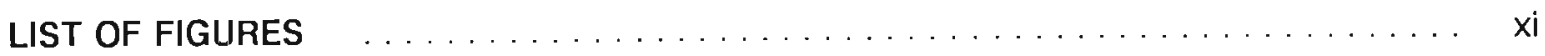

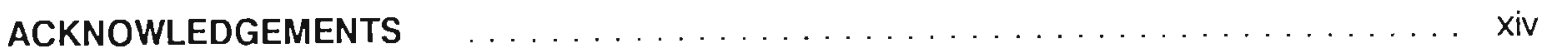

CHAPTER 1

INTRODUCTION

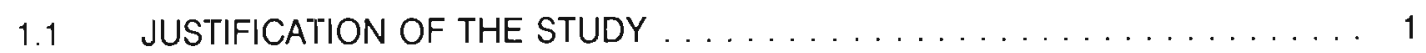

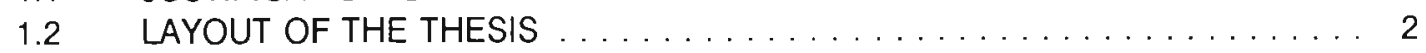

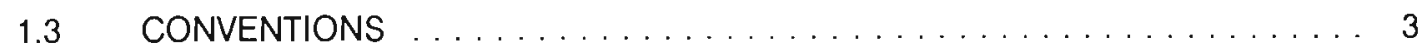

\section{CHAPTER 2}

HYDROLOGICAL EFFECTS OF FIRE

2.1 THE NATURE OF HYDROLOGICAL RESPONSES TO FIRE $\ldots \ldots \ldots \ldots$

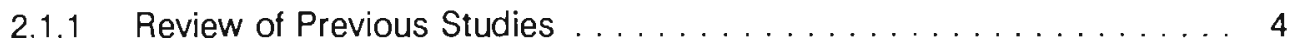

2.1.2 Hydrological Responses Attributable to Reduced Evaporation after

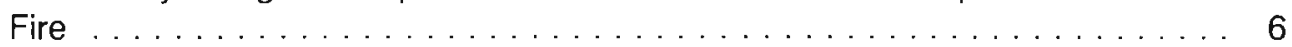

2.1.3 Hydrological Response due to Effects of Fire on the Soil . . . . . . 8

2.1.3.1 The effect of fire on soil temperatures . . . . . . . . . . 8

2.1.3.2 The effect of fire on soil erodibility . . . . . . . . . . . . 12

2.1.3.3 Fire-induced water repellency . . . . . . . . . . . . . . . . . . 12

2.1.3.4 The implications of water repellent soils . . . . . . . . . . . 14

2.2 FORMULATION OF AN HYPOTHESIS AND RESEARCH PLAN $\ldots \ldots \ldots \ldots$

\section{CHAPTER 3}

DESCRIPTION OF THE CATCHMENTS, TREATMENTS AND METHODS

3.1 DESCRIPTION OF THE CATCHMENTS AND TREATMENTS . . . . . . 23

3.1.1 The Jonkershoek Catchments . . . . . . . . . . . . . . . . 24

3.1 .2 The Jonkershoek Fire Treatments . . . . . . . . . . . . . . . 27

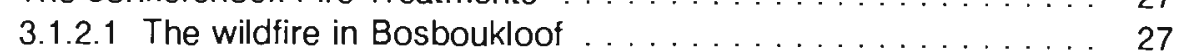

3.1.2.2 The prescribed fire in Swartboskloof . . . . . . . . . . . 27

3.1.2.3 The wildfire in Langrivier ... . . . . . . . . . . . . . . . 28

3.1.3 The Ntabamhlope Catchments . . . . . . . . . . . . . . . . . . 29

3.1.3.1 Geology and Soils ... . . . . . . . . . . . . . . . . . . 29

3.1 .3 .2 Climate and Hydrology .................... 29

3.1.3.3 Vegetation ........................ 30

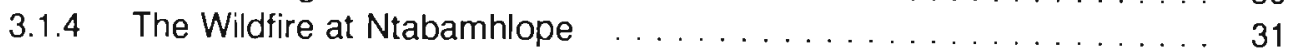

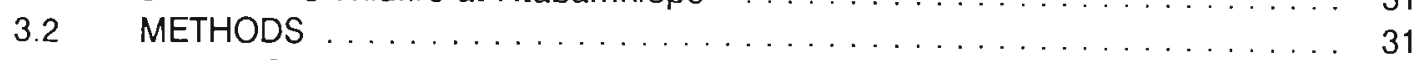

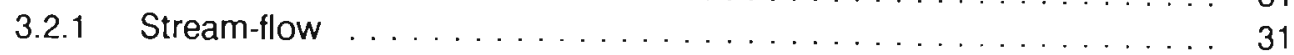

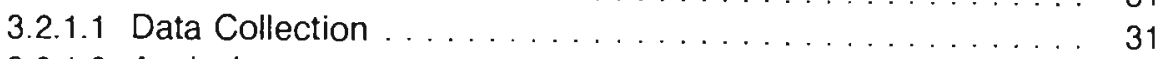

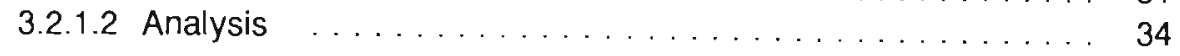




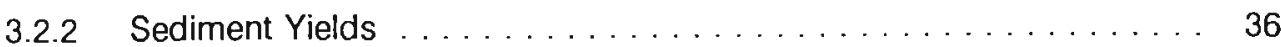

3.2 .3 Water Repellent Soils . . . . . . . . . . . . . . . . . . . . . 37

3.2 .4 Plot Studies . . . . . . . . . . . . . . . . . . 38

\section{CHAPTER 4}

\section{THE BOSBOUKLOOF STUDY}

4.1 STUDIES OF SOIL WEITABILITY $\ldots \ldots \ldots \ldots \ldots \ldots \ldots$

4.1.1 Design and Analysis of the Soil Wettability Study . . . . . . . . . . . . 40

4.1 .2 Results of the Soil Wettability Study . . . . . . . . . . . . . . . . . 41

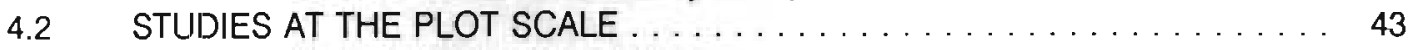

$4.2 .1 \quad$ Soil Erosion from Small Plots . . . . . . . . . . . . . . . . . . . 43

4.3 STUIDIES AT THE CATCHMENT SCALE . . . . . . . . . . . . . . . . . . 44

4.3 .1 Stream-flow ........................... 44

4.3 .2 Sediment Yields ........................... 48

4.4 THE EFFECTS OF CLEAR-FELLING ON STREAM-FLOW $\ldots \ldots \ldots \ldots$

4.4.1 Data Collection and Analysis . . . . . . . . . . . . . . . . . 50

$4.4 .2 \quad$ Hydrological Effects of Clear-felling . . . . . . . . . . . . . . . 51

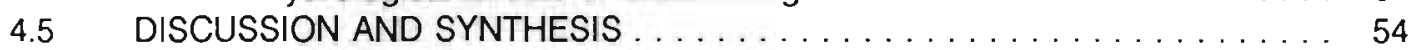

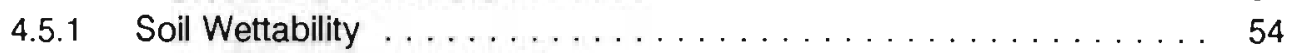

4.5 .2 Overland Flow and Soil Erosion . . . . . . . . . . . . . . . . 55

4.5.3 Stream-flow Generation in the Catchment . . . . . . . . . . . . . 56

4.5.4 Synthesis of the Results: The Process of Effects of Fire . . . . . . . 56

4.5.5 Comparison of Clear-felling and Fire Etfects . . . . . . . . . . . . 57

\section{CHAPTER 5}

THE SWARTBOSKLOOF STUDY

$5.1 \quad$ STUDIES OF SOIL WETTABILITY . . . . . . . . . . . . . . 59

5.1.1 Design and Analysis of the Soil Wettability Study . . . . . . . . 59

5.1 .2 Results of the Soil Wettability Study . . . . . . . . . . . 61

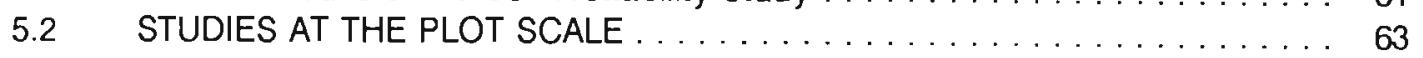

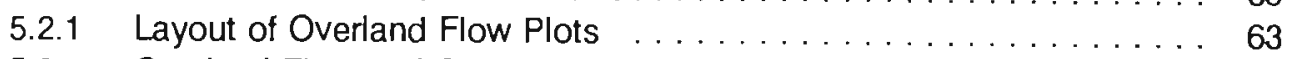

5.2 .2 Overland Flow and Soil Erosion on Small Plots . . . . . . . . 65

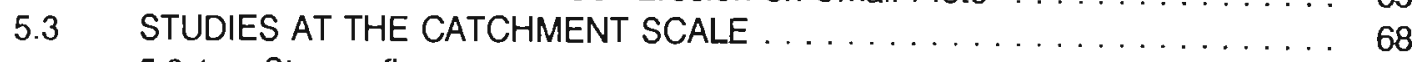

5.3 .1 Stream-flow . . . . . . . . . . . . . . . . . 68

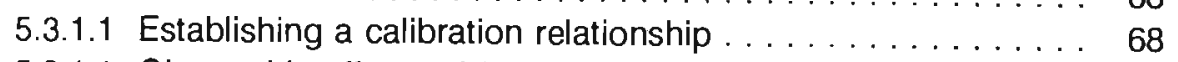

5.3.1.1 Observable effects of fire on stream-flow . . . . . . . . 69

5.3 .2 Sediment Yields ... . . . . . . . . . . . . . . . . 72

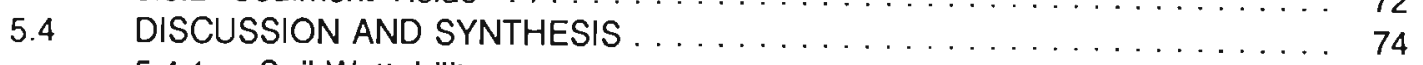

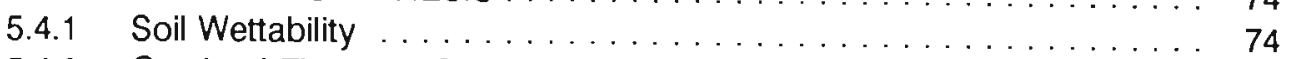

5.4 .2 Overland Flow and Soil Erosion . . . . . . . . . . . . . 75

5.4.2.1 Factors controlling overland flow and soil loss. . . . . . . 75

5.4.2.2 Recovery with time after disturbance $\ldots \ldots \ldots \ldots \ldots \ldots . \ldots 76$

5.4.2.3 Process of overland flow generation $\ldots \ldots \ldots \ldots \ldots \ldots 77$

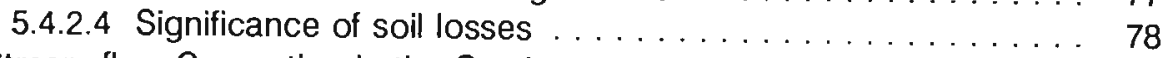

5.4 .3 Stream-flow Generation in the Catchment . . . . . . . . . . . 78

5.4 .4 Synthesis of the Results: The Process of Fire Effects $\ldots \ldots \ldots \ldots \ldots$
60

5.4 .5 Synopsis of Important Findings $\ldots \ldots \ldots \ldots \ldots \ldots \ldots \ldots \ldots \ldots . \ldots \ldots$ 


\section{CHAPTER 6}

\section{THE LANGRIVIER STUDY}

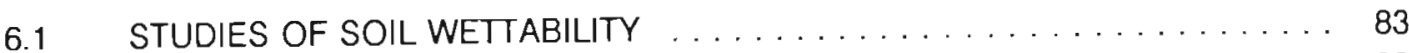

6.1.1 Design and Analysis of the Soil Wettability Study .......... 83

6.1 .2 Results of the Soil Wettability Study . . . . . . . . . . . . 84

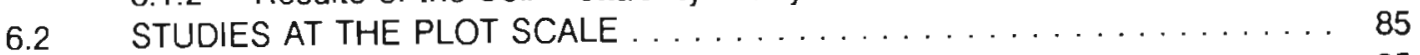

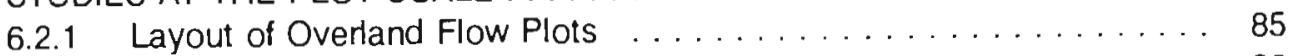

6.2 .2 Results from the Overland Flow Plots Study . . . . . . . . . . 86

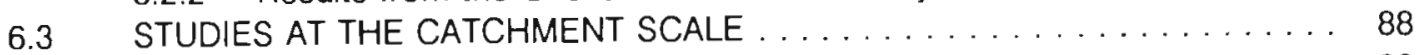

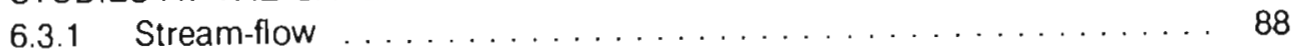

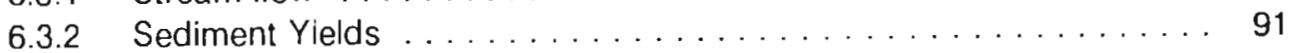

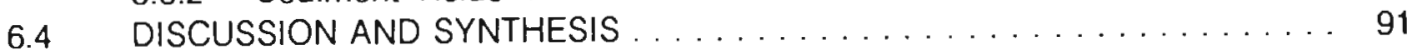

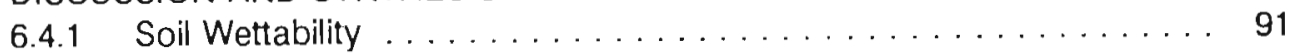

6.4 .2 Overland Flow and Soil Erosion . . . . . . . . . . . . . 92

6.4.3 Synthesis of the Results: The Process of Fire Effects . . . . . . . 93

\section{CHAPTER 7}

THE NTABAMHLOPE STUDY

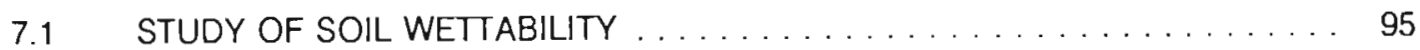

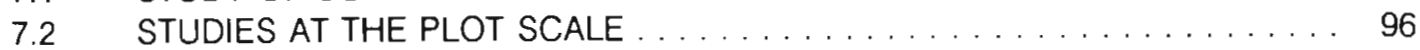

7.2 .1 Soil Erosion from Small Plots $\ldots \ldots \ldots \ldots \ldots \ldots \ldots \ldots . \ldots \ldots$

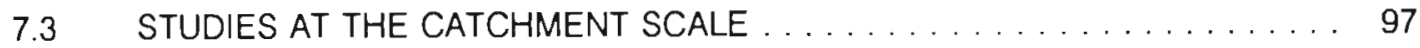

7.3 .1 Stream-flow . . . . . . . . . . . . . . . . . . 97

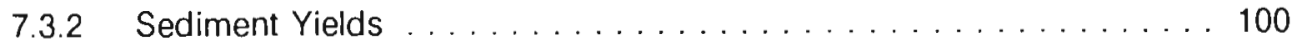

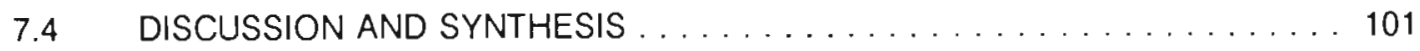

7.4.1 Overland Flow, Soil Erosion and Sediment Yields . . . . . . . . . . 101

7.4.1.1 Soil loss off small plots . . . . . . . . . . . . . . . . 101

7.4.1.2 Sediment yields and the role of the riparian 2uffer strip . . . . 104

7.4.2 Stream-flow Generation in the Catchment . . . . . . . . . . . 103

7.4.2.1 Total stream-flow and base-flow ... . . . . . . . . 103

7.4.2.2 Storm-flows ... . . . . . . . . . . . . . . . . . . 104

7.4.3 Synthesis of the Ntabamhlope Results . . . . . . . . . . . . . 105

7.4.4 A Comparison of Some Results from the Four Catchment Studies . 105

7.4.4.1 Stream-flow characteristics . . . . . . . . . . . . . 105

7.4 .4 .2 Sediment delivery ratios $\ldots \ldots \ldots \ldots \ldots \ldots \ldots \ldots$

\section{CHAPTER 8}

MODELLING THE HYDROLOGICAL EFFECTS OF FIRE

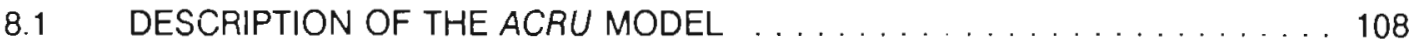

8.2 SETTING UP THE ACRU MODEL . . . . . . . . . . . . . . . . . 111

8.2.1 The ACRU Model in Distributed Mode . . . . . . . . . . . . . 111

8.2.2 The Dynamic Information Menu to Account for the Effects of Fire . . 112

8.3 COMPARISON OF SIMULATED AND OBSERVED STREAM-

FLOWS . . . . . . . . . . . . . . . . . . . . . . . . . . . 114

8.3.1 Observed Stream-flow Effects . . . . . . . . . . . . . . . . . . . 114

8.3.2 Simulated Stream-flow ... . . . . . . . . . . . . . . . . . . . 114

8.3.2.1 Total stream-flow . . . . . . . . . . . . . . 114

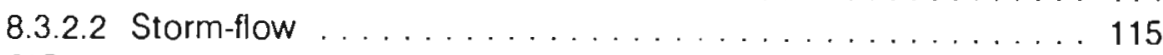

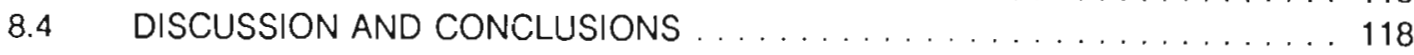




\section{CHAPTER 9}

SOIL WETTABILITY IN FORESTED AND

MOUNTAIN CATCHMENTS

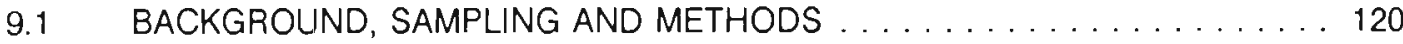

9.1 .1 Background to the Study . . . . . . . . . . . . . . . 120

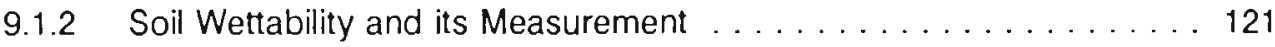

9.1.2.1 Water penetration time ................... 121

9.1.2.2 Liquid-solid contact angle . . . . . . . . . . . . . . . 122

9.1.2.3 Surface tension of the fluid . . . . . . . . . . . . . . 123

9.1.2.4 Sorptivity index . . . . . . . . . . . . . . . . . . 123

9.1.3 Sampling of Soils . . . . . . . . . . . . . . . . . . . . 124

9.2 RESULTS OF THE WETTABILITY TESTS . . . . . . . . . . . . . . . . 126

9.2.1 Correlations Between Variables . . . . . . . . . . . . . . . . . 126

9.2 .2 Analysis of Variance . . . . . . . . . . . . . . . . . . . 128

9.2.3 The Effect of Vegetation Type . . . . . . . . . . . . . . . . . . . 129

9.2.4 The Effect of Soil Texture . . . . . . . . . . . . . . . . . 132

9.2.5 Predicting the Risk of Repellency in Soil . . . . . . . . . . . . 133

9.3 DISCUSSION . . . . . . . . . . . . . . . . . . . . . . . . . 134

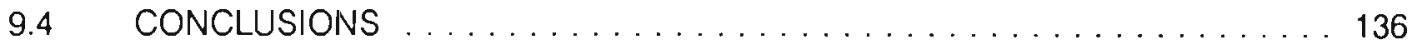

\section{CHAPTER 10}

\section{RAINFALL SIMULATOR STUDY}

10.1 STUDY DESIGN . . . . . . . . . . . . . . . . . . . . . . . . . . 137

10.1.1 The Rainfall Simulator . . . . . . . . . . . . . . . . . . . . 137

10.1.2 Experimental Layout . . . . . . . . . . . . . . . . . . . . . . 137

10.1.2.1 Application of treatments . . . . . . . . . . . . . . . 139

10.1.3 Problems Encountered with the Experiment . . . . . . . . . . . . 141

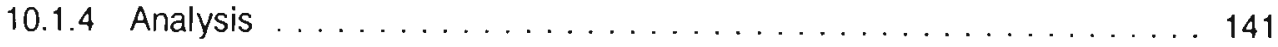

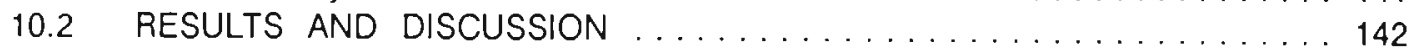

10.2.1 Results of the Split Plot ANOVA . . . . . . . . . . . . . . . . 142

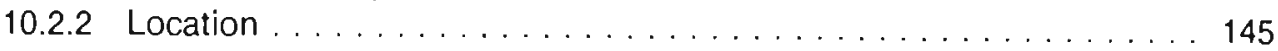

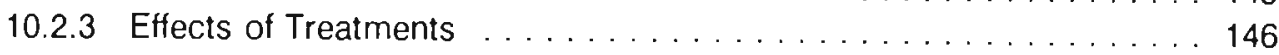

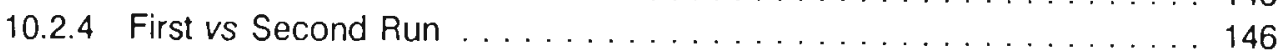

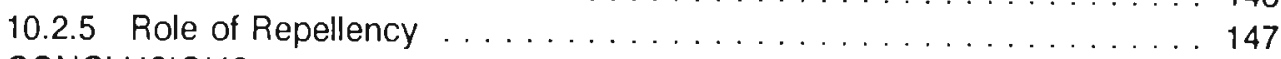

10.3 CONCLUSIONS ........................... 147

\section{CHAPTER 11}

CONCLUSIONS

11.1 REPELLENCY AS AN AGENT FOR HYDROLOGICAL EFFECTS OF

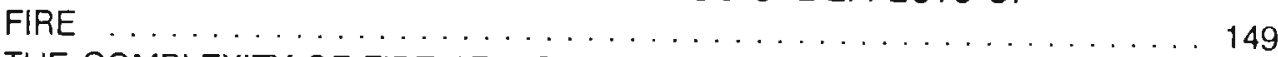

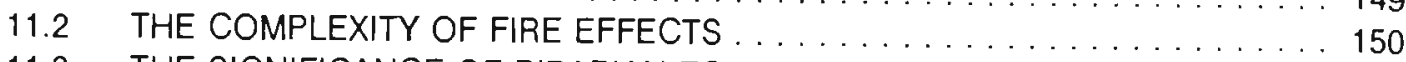

11.3 THE SIGNIFICANCE OF RIPARIAN ZONES AS BUIFFER STRIPS . . . . . . . 152

11.4 PLOTS AS MEANS OF STUDYING STREAM-FLOW GENERATION $\ldots \ldots \ldots . .152$

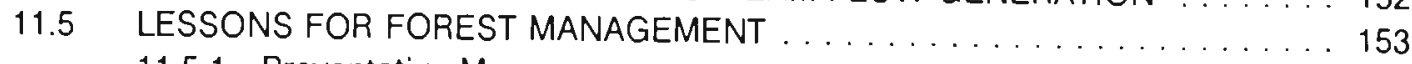

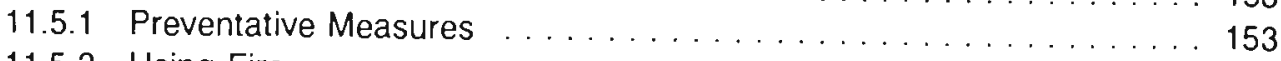

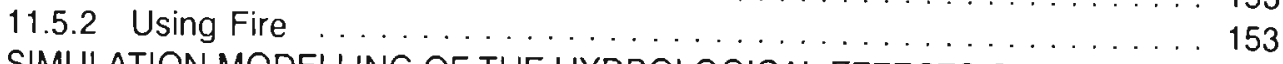

11.6 SIMULATION MODELLING OF THE HYDROLOGICAL EFFECTS OF
FIRE

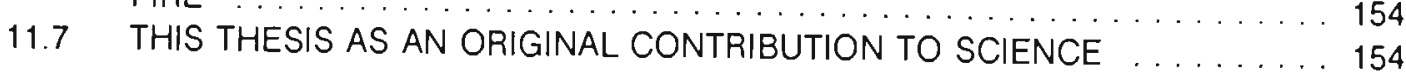




\section{LIST OF TABLES}

Table 2.1 Summary of catchment scale hydrological responses to fire.

Table 2.2 Summary of measurements of overland flow and sediment yield from plots.

Table 3.1 Summary of the physical features of the research catchments used in this study.

Table 3.2 Summary of the vegetation characteristics and treatments of the research catchments.

Table 3.3 Means and standard deviations (s.d.) of oven dry fuel loads $\left(\mathrm{g} \mathrm{m}^{-2}\right)$ in various fuel classes and fuel wetness at the two sites in the Swartboskloof catchment where overland flow plots were installed.

Table 3.4 The mean and standard deviations (s.d.) of the storm-flow variables measured in each research catchment over the pre-fire (calibration) periods.

Table 4.1 Significant $(a<0.05)$ predictor terms in the multiple regression models developed for the pre-fire and full periods of storm-flow data in the Bosboukloof catchment. The presence of the fire dummy variable $(F)$ in the full period models indicates a significant effect of fire.

Table 4.2 Increases in stream-flow variables as a result of the fire in the Bosboukloof catchment.

Table 4.3 Results of the non-parametric Wilcoxon-Mann-Whitney tests on the monthly suspended sediment yield data from the burned Bosboukloof and the control catchment, Lambrechtsbos-B.

Table 4.4 Significant $(a<0.05)$ predictor terms in the multiple regression models for the Bosboukloof catchment developed over the pre-clearing and full periods of streamflow data. The presence of the clear-fell dummy variable $(F)$ in the full models indicates a significant effect of felling.

Table 4.5 Increases in stream-flow variables as a result of clear-felling of timber plantations in the Bosboukloof catchment.

Table 5.1 The characteristic vegetation and soil features of the units in which repellency sampling was performed.

Table 5.2 Overall mean values, on a per storm basis, of the variables measured at the overland flow plots at sites A and B and the unburnt control plot. Standard deviations of the mean are given in brackets.

Table 5.3 Best regression models for explanation of overland flow and soil loss from small plots in the Swartboskloof catchment.

Table 5.4 Pearson correlation coefficients between dependent and independent variables for the single storms on the untreated control plot. The number of storm events in the sample was 35 over one year. 
Table 5.5

Table 5.6

Table 6.1

Table 6.2

Table 6.3

Table 6.4

Table 7.1

Table 7.2

Table 7.3

Tabular summary of fire effects on stream-flow and storm-flow: post-fire mean values and percentage change over expected (predicted) values for several stream-flow and storm-flow variables in the first post-fire year. Change figures in brackets are not significant. Negative percentage change indicates a decrease.

Table 7.4 The mean overland flow and soil loss from small plots (rows 2 - 5) and sediment yields from the whole catchment (rows 6 and 7) for all four burned catchments during the first post-fire year. (Standard deviation, where available, in brackets)

Table 9.1 The origin and some properties of a range of soils from forestry regions in South Africa. The mean value of organic carbon is shown with its standard error in brackets. The location codes cross-refer to Figure 9.1 and the text.

Table 9.2 Pearson correlation coefficients $(\boldsymbol{\rho})$ for a range of measures of water repellency and some potential predictor variables for a sample of South African forestry soils.

Table 9.3 The results of the analysis of variance of three measures of water repellency of a sample of South African forestry soils.

Table 9.4 A preliminary decision-tree to estimate the probability of any particular forest soil in South Africa being or becoming water repellent.

Table 10.1 Site and soil characteristics of the three locations used in the rainfall simulator study of fire effects. (Standard deviation, where available, in brackets) 
Table 10.2 Details of the simulated rain storms at each of two sites (replicates) at three forestry locations in the Natal Midlands.

Table 10.3 Results of the analysis of variance by a split-plot design of three variables measured in the rainfall simulator trial.

Table 10.4 Overland flow and soil loss from the rainfall simulator plots averaged by the four treatments over three sites, two runs and two replicates, i.e. $n=12$. (The mean value is shown with its standard deviation in brackets).

Table 10.5 Overland flow and soil loss from the rainfall simulator plots averaged by three locations over four treatments, two runs and two replicates, i.e. $n=16$.

Table 10.6 Overland flow and soil loss from the rainfall simulator plots averaged by run over four treatments, three locations and two replicates, i.e. $n=24$. 


\section{LIST OF FIGURES}

Figure 2.1 The volumetric heat capacity (a) and thermal conductivity (b) of some soil elements. Note: at $100 \%$ volumetric wetness the soil is saturated; the porosity of the sand and clay is $40 \%$; the properties of organic matter are highly variable but may be approximated by those of peat. Data from Van Wijk and De Vries (1963); Chandler et al. (1983).

Figure 2.2 Temperature-time curves at various depths $(\mathrm{mm})$ in the soil beneath (a) moderate and (b) high intensity grassland burns in New South Wales (Norton and McGarrity, 1965), (c) light (d) moderate and (e) intense burns in Californian chaparral on dry soils (DeBano et al., 1977), and ( $f$ ) eucalypt slash pile burn in New South Wales (Humphreys and Lambert, 1965).

Figure 2.3 Water repellency in soil as altered by fire: (a) before fire hydrophobic substances accumulate in the litter layer and in the mineral soil immediately beneath it; (b) during fire the surface layer is heated, destroying some repellent substances while others are volatilised and move downward into the soil profile along a temperature gradient; and (c) after a fire the water repellent layer is below and parallel to the soil surface (DeBano, 1969b).

Figure 2.4 Idealised sketch of how a water repellent soil below the soil surface impedes percolation and may lead to saturation overland flow (DeBano, 1969c).

Figure 3.1 The location and topography of the Jonkershoek Valley and its research catchments, showing their boundaries and names.

Figure 3.2 Location and topography of the Ntabamhlope catchments, $\mathrm{V}_{1} \mathrm{H} 020$ and $\mathrm{V} 1 \mathrm{H} 028$ catchments.

Figure 3.3 The standardised storm hydrograph classification method of Hewlett and Hibbert (1967).

Figure 4.1 A schematic representation of the soil wettability sampling results from Bosboukloof showing the proportion of 12 samples at each depth in each repellency class.

Figure 4.2 The soil losses measured on three overland flow plots on slopes of 27,35 and $62 \%$ in the Bosboukloof catchment.

Figure 4.3 Time plots of the differences between the observed and expected values of (a) quickflow volume, (b) peak discharge and (c) response ratio in Bosboukloof over the calibration and post-fire periods.

Figure 4.4 The deviations in weekly stream-flow volumes about the calibration regression relationship in Bosboukloof, indicating the declining yield increase in the four hydrological years following fire.

Figure 4.5 Monthly suspended sediment yields in Bosboukloof and its control catchment, Lambrechtsbos-B, before and after the fire in Bosboukloof in February 1986.

Figure 4.6 A time plot of the difference between the observed and expected weekly stream-flow in Bosboukloof over the calibration, felling and post-felling periods.

Figure 5.1 A schematic representation of the soil wettability sampling results from Swartboskloof showing the proportion of 15 profiles at each depth in each repellency class before and after fire.

Figure 5.2 Maximum (open bar) and total (open plus solid bar) soil loss (note log scale), and mean (bar) and maximum (whisker) overland flow from seven plots in Swartboskloof in the first year of measurement. 
Figure 5.3 Mean monthly soil loss and overland flow depth (as percentage of rainfall, P) from six burned plots in Swartboskloof after fire in March 1987, showing marked reductions in the second year.

Figure 5.4 Annual water balance (for hydrological years) for Swartboskloof catchment, estimated by mass balance over the available period of record. Height of the bar indicates annual precipitation, hatched is base-flow, crosshatched is quick-flow volume and dotted is residual (= evaporation).

Figure 5.5 The annual response ratio for Jonkershoek catchments plotted against mean annual rainfall. Data are for the longest period available (mostly in excess of 20 years). Swartboskloof is indicated as a triangle.

Figure 5.6 Weekly stream-flow volumes (log of $\mathrm{mm}$ values) in Swartboskloof $(-)$ and the corresponding week's volume in Tierkloof (---) plotted against the rank of Swartboskloof volumes.

Figure 5.7 Differences between observed quick-flow volumes from the Swartboskloof catchment and predictions from the calibration equation.

Figure 5.8 Monthly suspended sediment export from Swartboskloof: (a) averaged over three years, (b) mean concentration, (c) mass and (d) corresponding stream-flow volume (Scott and Van Wyk, 1992).

Figure 6.1 The proportion of 20 soil sample profiles in three soil wettability classes in Langrivier catchment contrasted against 75 unburned profiles in Swartboskloof.

Figure 6.2 Means of overland flow depth per storm event and mean monthly soil loss from three plots in the burned Langrivier catchment.

Figure 6.3 Time plot of the deviations of weekly stream-flow volume about the fitted calibration model which had an adjusted $R^{2}=0.98$.

Figure 7.1 Sample hydrographs from Ntabamhlope catchments V1H020 (solid line) and V1H028 $(-+-)$ illustrating the change in the relationship between the catchments after the August 1989 fire(a. \& b. before; c. - f. after).

Figure 7.2 Plot of the hydrograph at weir V1H020 (solid line) for 15 December 1989 showing suspended sediment concentrations $(\Delta)$ and electrical conductivity values $(+)$ of water samples taken during the storm.

Figure 8.1 A diagrammatic depiction of the structure of the ACRU agro-hydrological model, Version 2 (Schulze, 1989a).

Figure 8.2 The layout, vegetation types and size of the sub-catchments within catchment $\mathrm{V} 1 \mathrm{H} 020$ at Ntabamhlope for purposes of distributed modelling.

Figure 8.3 The monthly values of four model variables showing how they were set to accommodate before and after fire conditions in the burned sub-catchments at Ntabamhlope.

Figure 8.4 Time-plot of the observed and simulated monthly totals of daily stream-flow for catchment $\mathrm{V}_{1} \mathrm{H} 020$ at Ntabamhlope.

Figure 8.5 Time plots of the observed and simulated daily stream-flow volume in Ntabamhlope catchment $\mathrm{V} 1 \mathrm{HO} 20$ for $\mathrm{dry}$ and wet periods before (Figure 8.5a) and after (Figure $8.5 b)$ the fire. Note the scale differences on the vertical axes Figure 8.6 Time-plot of the observed and simulated storm-flow volumes for individual storms in
catchment $\mathrm{V} 1 \mathrm{H} 020$ at Ntabamhlope. 
Figure 9.1 The approximate locations of the forestry sites in South Africa from which soils were sampled for repellency testing. The location codes cross-refer to Table 9.1 and the text.

Figure 9.2 The results of four different measures of water repellency in soils from beneath four vegetation types from the forestry regions of South Africa. High values of critical surface tension (a), infiltration index (b) and height of capillary rise after 24 hours (c). and low values of apparent contact angle (d) indicate weaker repellency. (Note that only a subset of the vegetation types grow at each location.)

Figure 9.3 The effect of vegetation type on four measures of soil wettability averaged over all sample locations at which soils beneath the vegetation type were sampled.

Figure 9.4 Time plots of the height of rise of water up columns of soil from two locations in Natal - (a) Cathedral Peak and (b) Windy Hill near Wartburg.

Figure 10.1 The temperature of the soil at different depths beneath a eucalypt slash pile during burning (E1, replicate 1, near Richmond, Natal).

Figure 10.2 The mean steady infiltrability of two replicates of four treatments (bare, control, dry burn and wet burn) at three forestry locations in Natal.

Figure 10.3 The mean overland flow depth (as a percentage of simulated rainfall) of two replicates of each of four treatments (bare, control, dry burn and wet burn) at three forestry locations in Natal.

Figure 10.4 The mean soil loss of two replicates of each of four treatments (bare, control, dry burn and wet burn) at three forestry locations in Natal. 


\section{ACKNOWLEDGEMENTS}

The completion of this thesis would not have been possible without the help of many people and institutions, to all of whom I am greatly in debt.

The task of a hydrologist is made much easier by good data. I have been lucky to be provided with an enormous amount of exceltent data and thank field and laboratory staff at Jonkershoek Forestry Research Centre and the Department of Agricultural Engineering of the University of Natal, Pietermaritzburg (UNP) for their efforts to collect and process the hydrological data to which I have had access. In particular, the field and technical assistance of Godfrey Moses and Cobus Pretorius was invaluable.

For assistance and guidance with statistical analyses of the data I am indebted to $\mathrm{Mr}$ Harvey Dicks and Prof Peter Clark of the Department of Statistics and Biometry at UNP. The Computing Centre for Water Research provided me with excellent computing facilities and willing service, without which my task would have been much greater.

I thank the Department of Agricultural Engineering, UNP, for office space, services and companionship during my three-and-a-half year residence at the department while involved in this study. Because of the strong emphasis on soils in this thesis I needed to lean heavily on the hospitality of the Agronomy Department, UNP, who provided encouragement, advice and laboratory facilities. My particular thanks to Mr Mike Johnston of this Department for teaching me all I know about soil physics and making it interesting.

This study started of as an official research project of the South African Forestry Research Institute of the Department of Environment Affairs and was completed under a research contract between my employer, the CSIR Division of Forest Science and Technology, and the Forestry Branch of the Department of Water Affairs and Forestry. I am grateful to these State departments for their sponsorship and the confidence shown in me. I also benefitted, indirectly, from Water Research Commission funding to maintain the Ntabamhlope catchments and the Computing Centre for Water Research. 
For providing field sites and logistic support for the rainfall simulator study I thank Mondi Forests and Wally Keyser of Fred Keyser and Sons of Mid-Illovo. For permission to establish research plots in the Ntabamhlope catchments I thank Masonite Ltd.

A special word of thanks to my academic supervisor, Roland Schulze, and colleagues Jan Bosch and Fred Kruger for helpful advice on the project; and to Roland, Arthur Chapman, Dirk Versfeld, Hans Keller, Brian van Wilgen and anonymous reviewers for critical reading of drafts of thesis material.

Magdel van der Merwe, super-typist, brought a welcome injection of enthusiasm and a large dose of professionalism to the final stages of the preparation of this thesis.

Finally, my heart-felt thanks to my wife, Helene, and my parents who always encouraged me and never doubted my ability. 


\section{CHAPTER 1}

\section{INTRODUCTION}

\subsection{JUSTIFICATION OF THE STUDY}

South Africa is generally a semi-arid country and water is a limiting factor in its further economic development. The mountainous areas that receive higher rainfall are important as the source of the country's rivers. Proper management of these water-yielding catchments is critical therefore in the control of water resources. Apart from the very limited area of indigenous forest $(0.5 \%$ of the-land surface), all the catchments still carrying indigenous vegetation are subject to management by regular burning, and these vegetation types are adapted to fire. In the past century large parts of the more humid catchment areas have been afforested to timber species (Pinus, Eucalyptus and Acacia spp.). This trend of afforestation continues. The timber plantations are at risk of burning as they are surrounded by fire-prone and fire-maintained vegetation. The hydrological response of these afforested catchments to fire may be different from that of the naturally vegetated catchments. It is important therefore to understand the risks and causes of different hydrological responses to fire in all these high rainfall catchments, both natural and afforested.

A review of the international literature (Chapter 2) shows that fire carries with it a risk of downstream flooding, mass failures (landslides, mudslides), increased soil erosion (hence a potential loss of site fertility and productivity), accelerated sedimentation of reservoirs and a consequent loss of storage capacity. Yet not all fires have the same impact and several fire, fuel and vegetation characteristics may influence the effects of a fire.

The role of fire in the hydrology of South African catchments is not well understood and, other than the long-term effect on water yield, has received relatively little research attention. However, some documented instances illustrate that fire can transform the hydrological behaviour of a catchment. The studies on which this thesis is based arose from a need to understand the hydrological processes which cause a response to a fire and the circumstances in which such a response could be expected. In an initial pilot 
study, water repeliency in the soils was observed and it appeared that this phenomenon could be important in the hydrological response of the whole catchment. This observation led to a study of soil wettability in parallel with an analysis of changes in stream-flow response from the catchment as a central objective of this thesis.

\subsection{LAYOUT OF THE THESIS}

In broadest terms this thesis has two major parts. The first is a series of four detailed catchment analyses in which the effects of fire were investigated at point, plot and catchment scales. The second part describes three supplementary studies, namely, runoff modelling, the occurrence of water repellency and rainfall simulator trials, which sought to broaden the applicability of the findings of these detailed studies to a greater geographical range.

Chapter 2 provides a review and analysis of the topic of the hydrological effects of fire, as reported in the scientific literature, and uses this as a basis for formulating a hypothesis to be tested in the thesis. Chapter 3 gives a general introduction to the studies in the gauged catchments, with descriptions of the catchments and of the methods and analyses which were used repeatedly in subsequent chapters. Chapters 4 to 7 are detailed accounts of the results of the studies of the fires in four gauged catchments, with a discussion of the results of each. Each study had some unique aspects which are described in detail within each catchment-specific chapter.

Chapter 8 describes an exercise in which an existing hydrological model was used to simulate the effects of a fire on stream-flow. Chapter 9 reports on a study of the inherent water repellency of soils from beneath timber plantations and indigenous vegetation types over a wide geographical distribution in South Africa. A rainfall simulator was used to study the hydrological effects of fire on small plots, and this study is reported in Chapter 10. Chapter 11 contains the conclusions, discussing the extent to which the initial hypothesis was supported by the studies, and drawing together the general conclusions of the studies. As the requirements of the Ph.D. degree include originality, a section of the conclusions presents an argument in support of the scientific contribution of the studies recorded in these pages. 


\subsection{CONVENTIONS}

The style of referencing literature and expressing units of measure is that specified for the Journal of Hydrology. Spelling is according to Chambers 20th Century Dictionary. Where technical words do not appear in the dictionary the standard convention for hydrology, where one existed, was used. The format follows the requirements of the Faculty of Science, University of Natal, Pietermaritzburg.

Much of the work contained in this thesis has already been published in some form or another. Some of these publications carried co-authors. In this thesis I have referred to these previous publications only where the specific work being referred to was not my original effort. This has notably been in the collection and preparation of the sediment yield data in the Jonkershoek catchments by my colleague Danie Van Wyk. I have benefited from the comments received from various reviewers of papers derived from the thesis work, and many of these have been incorporated into this document, sometimes directly and in some cases through their influence on my approach to the study. 


\section{CHAPTER 2}

\section{HYDROLOGICAL EFFECTS OF FIRE}

In this chapter a literature review of the hydrological effects of fire is presented. This will provide the background and theoretical basis for this study. Firstly the general nature and range of hydrological responses to fire as well as certain effects of fire on soil, as recorded in various parts of the world, are presented, and this is followed by the development of the hypothesis underlying the design of this study. The chapter concludes with an outline of the associated research plan.

\subsection{THE NATURE OF HYDROLOGICAL RESPONSES TO FIRE}

\subsubsection{Review of Previous Studies}

The hydrological response to fire has been the subject of considerable research and a wide range of responses has been recorded, as illustrated in the reviews by Anderson et al. (1976) and Tiedemann et al. (1979). This range in responses is due to the varied characteristics of fire and site encountered in these studies. In this regard the season of burn, rate and amount of energy released, geological and soil factors, basin morphology, vegetation type and climate may all be important. Thus, a uniform hydrological response to fire should not be expected. Tables 2.1 and 2.2 (located at the end of this chapter) summarise some of the findings on fire's effects on stream-flow and sediment yields, at catchment and plot levels respectively.

Some of the hydrological effects of fire that have been reported are,

(i) reduced infiltration rates and associated increases in overland flow (Arend, 1941; Anderson, 1949; DeBano, 1971; and Dyrness, 1976),

(ii) accelerated soil erosion and sedimentation (Hoyt and Troxell, 1934; Sinclair, 1954; Cooper, 1961; DeByle and Packer, 1972; Brown, 1972; Leitch et al., 1983; Van Wyk, 1986; and others cited in Anderson et al., 1976), 
(iii) triggering of debris flows and mass wasting (Mersereau and Dyrness, 1972; DeBano et al., 1977) and

(iv) increased total discharge, peak flows and storm-flows (Hoyt and Troxell, 1934; Rycroft, 1947; Brown, 1972; Campbell et al., 1977).

The hydrological consequences of fire have often been observed as being striking. One of the earliest assessments of the effects of fire was in the chaparral-vegetated San Gabriel Mountains of Southern California and this showed that total water yield, peak discharge and storm-flow volumes increased considerably after fire, and these increases were associated with accelerated soil erosion and sedimentation (Hoyt and Troxell, 1934). In their detailed study these authors also reported shorter response times and higher baseflows in the burned catchment relative to an unburned control.

This fire-flood-erosion sequence in the mountainous chaparral areas of California and Arizona is a well-documented phenomenon (Anderson et al., 1976), through the studies of numerous workers in the area. Several such cases are cited by Colman (1951). For example, a single large rain storm following a wildfire near La Crescenta in California resulted in an extremely high soil loss of $306 \mathrm{t} \mathrm{ha'.} \mathrm{In} \mathrm{another} \mathrm{extreme} \mathrm{case} \mathrm{total} \mathrm{stream-}$ flow increases of up to $800 \%$ were recorded after a wildfire in a ponderosa pine forest in Arizona (Campbell et al., 1977). Similarly, large increases in flooding and erosion followed wildfires in eucalypt forests in those parts of Australia which also have summer fire seasons (e.g. Brown, 1972; Leitch et al., 1983). In the fynbos (macchia-like vegetation) area of the south-western Cape Province of South Africa, in the small $\left(0.12 \mathrm{~km}^{2}\right)$ Abdolskloof catchment in the Jonkershoek Valley, sharp - though short-lived - increases in storm-flow, peak discharge and total stream-flow were recorded in the first three months of the wet season immediately following a wildfire (Rycroft, 1947; Banks, 1964).

The consequences of wildfires may have serious environmental and economic costs, both on the burned site and downstream. In steep mountainous regions there is clearly a real economic threat posed by the possibility of flooding and debris flows which follow some fires.

By contrast to the results cited above, several other studies have reported no perceivable, or only minor, hydrological responses to fire (Biswell and Schultz, 1957; Nänni, 1960; Knighton, 1977; Van Lear et al., 1985; Lindley et al., 1988). For example, the Wheeler 
Springs fire burned 12000 ha of chaparral in California, but led to no detectable increase in flooding and little accelerated erosion (Colman, 1951). Prescribed burning in a pine plantation and a wildfire in eucalypt forest in Australia (Ronan, 1986) and burns in pine woods in the south-eastern USA (Knighton, 1977; Van Lear et al., 1985) caused no marked hydrological change. The above studies, however, were undertaken mainly on prescribed burns. In a review of the hydrological effects of fire in South African ecosystems, Bosch et al. (1984) conclude that with the exception of the study by Rycroft (1947), noted above, the effects of fire on hydrological responses at the catchment scale are minor or not detectable. Again the fires under review were primarily prescribed burns.

\subsubsection{Hydrological Responses Attributable to Reduced Evaporation after Fire}

Hydrological consequences of fire may be assigned to two causes, namely

(i) the reduced evapotranspiration in a burned catchment caused by the removal of most of the vegetation, and

(ii) the direct effects of the heating of the soil by the fire.

Catchment evapotranspiration $(E)$ is the sum of evaporation from the soil surface $\left(E_{s}\right)$ and open water surfaces $\left(E_{o}\right)$, and of transpiration $\left(E_{l}\right)$ and intercepted precipitation $\left(E_{i}\right)$ (Hewlett, 1982), i.e.

$$
E=E_{s}+E_{o}+E_{t}+E_{i}
$$

In a well wooded catchment $E_{s}$ and $E_{o}$ will be very small relative to $T$ and $l$, to the extent that they may be neglected under fully afforested conditions (Hewlett, 1982). After a fire in a wooded catchment, the original major components of the above equation, $E_{1}$ and $E_{i}$, are reduced to almost zero. To a minor extent this is compensated for by an increase in $E_{s}$ as a consequence of increased net solar radiation loading on the ground through reduced albedo of the ash-blackened soil surface and increased wind movement over it. For instance, immediately after a fire in a tall grassland in Natal, South Africa, albedo decreased from $15 \%$ to nearly $3 \%$ at noon, and was associated with soil temperature and net radiation increases (Savage and Vermeulen, 1983). Overall, though, a net reduction in evapotranspiration from the burned catchment can be expected. 
Reduced evaporative losses will translate into increased stream-flows following fire for similar reasons as those caused by clear-felling and would be of a similar magnitude. The size and magnitude of the changed stream-flow response following clearing of the vegetation will depend on the type, age and biomass of vegetation supported by the catchment, the proportion of the catchment affected and the precipitation characteristics of the catchment, as indicated in the review of deforestation and afforestation experiments by Bosch and Hewlett (1982). Reduced evaporative losses can be expected to increase general catchment wetness, and result in generally higher storm-flow volumes and peak discharge. Examples of a deforestation-linked effect of fire are the increases in total flow recorded after fires in the Wilson River catchment in Oregon, the Burns Watershed in Washington, and the Etajima Island catchments in the Hiroshima Prefecture of Japan (Anderson, 1976; Helvey et al., 1976; and Kusaka et al., 1983, respectively; Table 2.1).

The duration of the effects of a fire will depend on the time required to restore pre-fire canopy conditions. In humid montane grassland of the Natal Drakensberg in South Africa fire did not lead to any noticeable change in stream-flows (Nänni, 1960) and caused only minor changes in storm-flows (Bosch et al., 1984). This can be explained by the recovery of full canopy biomass by the burned grasslands within two months into the growing season which is also the wet season (Everson et al., 1989). Prescribed burns in fynbos catchments of the south-western Cape province led to small $(7-15 \%)$ increases in total stream-flow, but of short duration only (1 - 3 years) (Lindley et al., 1988). The proportion of sprouting to seed-regenerating vegetation in a fynbos catchment has been used to model the size and duration of the catchment's response to fire (Bosch et al., 1986); the higher the proportion of sprouting vegetation the quicker the recovery of biomass and hence the shorter the duration of stream-flow increases after fire. Similarly, models based on changes in total evaporation $(E)$ are used to estimate increases in stream-flow following fire in the Pacific Northwest in the USA (Potts et al., 1989).

A notable exception to the general pattern of fire-induced increases in stream-flow is the case of a tall, mature Eucalyptus regnans forest in the Southern Highlands of Victoria, Australia, which burned in a high-intensity fire in 1939. From three to five years after the fire a reduction in stream-flow was recorded which persisted for 21 years and averaged 214 $\mathrm{mm} \mathrm{a}^{1}$ (Langford, 1976). The stream-flow reduction was attributed to increased vigour in the regenerating forest relative to the previous mature forest. 
Reduced evaporative losses will translate into increased stream-flows following fire for similar reasons as those caused by clear-felling and would be of a similar magnitude. The size and magnitude of the changed stream-flow response following clearing of the vegetation will depend on the type, age and biomass of vegetation supported by the catchment, the proportion of the catchment affected and the precipitation characteristics of the catchment, as indicated in the review of deforestation and afforestation experiments by Bosch and Hewlett (1982). Reduced evaporative losses can be expected to increase general catchment wetness, and result in generally higher storm-flow volumes and peak discharge. Examples of a deforestation-linked effect of fire are the increases in total flow recorded after fires in the Wilson River catchment in Oregon, the Burns Watershed in Washington, and the Etajima Island catchments in the Hiroshima Prefecture of Japan (Anderson, 1976; Helvey et al., 1976; and Kusaka et al., 1983, respectively; Table 2.1).

The duration of the effects of a fire will depend on the time required to restore pre-fire canopy conditions. In humid montane grassland of the Natal Drakensberg in South Africa fire did not lead to any noticeable change in stream-flows (Nänni, 1960) and caused only minor changes in storm-flows (Bosch et al., 1984). This can be explained by the recovery of full canopy biomass by the burned grasslands within two months into the growing season which is also the wet season (Everson et al., 1989). Prescribed burns in fynbos catchments of the south-western Cape province led to small $(7-15 \%)$ increases in total stream-flow, but of short duration only (1 - 3 years) (Lindley et al., 1988). The proportion of sprouting to seed-regenerating vegetation in a fynbos catchment has been used to model the size and duration of the catchment's response to fire (Bosch et al., 1986); the higher the proportion of sprouting vegetation the quicker the recovery of biomass and hence the shorter the duration of stream-flow increases after fire. Similarly, models based on changes in total evaporation $(E)$ are used to estimate increases in stream-flow following fire in the Pacific Northwest in the USA (Potts et al., 1989).

A notable exception to the general pattern of fire-induced increases in stream-flow is the case of a tall, mature Eucalyptus regnans forest in the Southern Highlands of Victoria, Australia, which burned in a high-intensity fire in 1939. From three to five years after the fire a reduction in stream-flow was recorded which persisted for 21 years and averaged 214 $\mathrm{mm} \mathrm{a}^{\prime}$ (Langford, 1976). The stream-flow reduction was attributed to increased vigour in the regenerating forest relative to the previous mature forest. 


\subsubsection{Hydrological Response due to Effects of Fire on the Soil}

The second source of an altered hydrological response to fire is the direct effect of heating the soil during the fire. In order to understand this effect it is necessary to examine briefly the heating process in soil.

\subsubsection{The effect of fire on soil temperatures}

Of the energy of combustion released during a fire, about $75 \%$ is as convection (transfer of energy as the flow of a heated body) and the remainder as radiation: conduction is only important in transferring energy within single logs (Luke and McArthur, 1977). Heat transfer from the fire to the soil is principally by radiation and constitutes roughly $5 \%$ of total energy releases (King, 1962; Packham, 1970). Soil temperatures during a fire would therefore never be as high as near-ground air temperatures.

The downward heating of soil is further limited by the generally poor thermal conductivity of soil. Soil temperatures do vary greatly under fires both in terms of degree and depth of heating, resulting in fire effects which range from insignificant to highly marked. The factors controlling the response of soil temperature to fire are

(i) fire intensity, which is defined by Albini (1976, cited by Wells et al., 1979) as the amount and rate of energy release,

(ii) the presence or absence of plant litter as an unincorporated insulating layer on the soil surface, and

(iii) soil characteristics, of which soil wetness is most important.

Although the intensity of fire is seldom given accurately (Alexander, 1982), a distinction is made typically between prescribed burns and wildfire. Fires prescribed to meet management goals are usually characterised by a low fire intensity. Herbaceous vegetation types such as grassland typically have low fuel loads and consequently lower fire intensities. Scrub and shrub vegetation types may approach the ground fuel loads of forests, but the highest fuel loads are those which are formed artificially, such, slash piles in felled forests. Fires which occur when fuels are dry will release more energy as radiation and convection and less as latent heat (vaporisation of fuel moisture). The higher rate of combustion of dry fuels will further increase fire intensity. 
Typical values of the volumetric heat capacity and thermal conductivity of some soil constituents are shown in Figures 2.1a and 2.1b. From these it can be seen that an increase in soil wetness greatly increases the soil heat capacity and conductivity. By contrast, a higher proportion of air-filled soil pores and an increase in humus content will have the opposite effect because of the low thermal conductivity of both air and organic matter and the low heat capacity of air relative to other soil components.

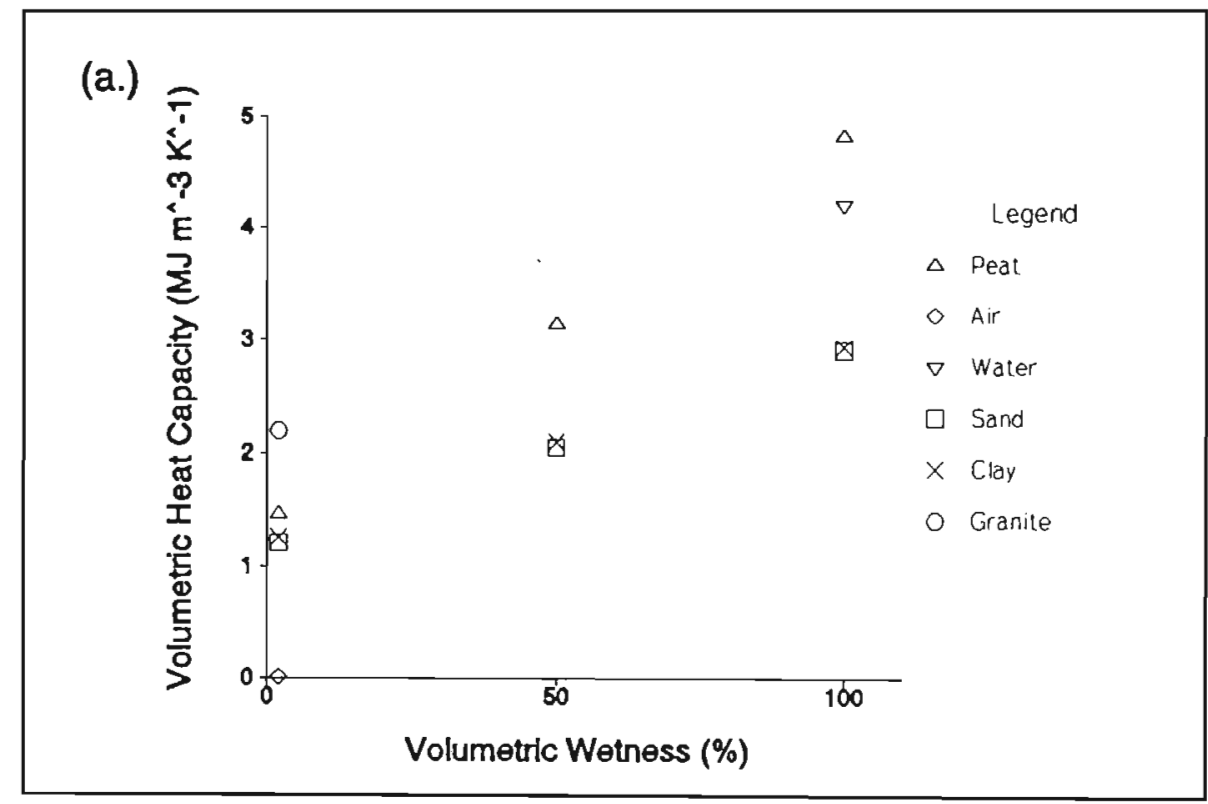

(b.)

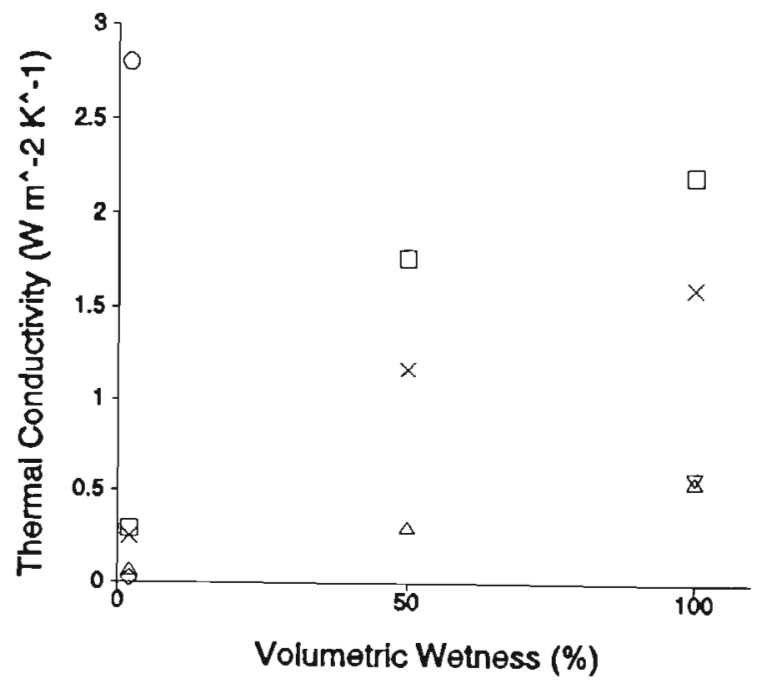

Figure 2.1 The volumetric heat capacity (a) and thermal conductivity (b) of some soil elements. Note: at $100 \%$ volumetric wetness the soil is saturated; the porosity of the sand and clay is $40 \%$; the properties of organic matter are highly variable but may be approximated by those of peat. Data from Van Wijk and De Vries (1963); Chandler et al. (1983). 
The implication of these thermal properties is that dry soil, with a low bulk density, will tend to heat to higher temperatures and transfer less of the heat to soil deeper in the profile. In any case, moisture in a soil must be driven off before the soil temperature will rise above $100^{\circ} \mathrm{C}$ (Scotter, 1970).

The low thermal conductivity of organic matter (Figure 2.1b) makes unincorporated litter or duff an excellent insulator of the underlying soil (Heyward, 1938; Kozlowski and Ahlgren, 1974; Chandler et al., 1983). For example, a litter layer of $10 \mathrm{~mm}$ over the soil prevented heating of the soil during a grass fire (Bentley and Fenner, 1958). The typically deep, fine and moist litter mats in coniferous forests Nan Wagner, 1972) can provide considerable insulation against heating during fire. The litter layer provides insulation even when reduced to ash (Scholl, 1975).

More important than maximum soil temperatures experienced during a fire are temperature-duration data (Brown and Davis, 1973; DeBano et al., 1979; Pritchett, 1979). The six temperature versus time plots in Figure 2.2 illustrate the typical soil heating patterns at different depths in the soil for different fuel types in grassland, shrubland and the very heavy fuel load of a forest slash pile (windrow). The grassland and slash pile graphs are from measurements of single fires, while the shrubland curves are synthesised from data collected from numerous chaparral fires by DeBano et al. (1977).

Of particular significance in Figures $2.2 \mathrm{a}-\mathrm{f}$ are the lagging of heat penetration to greater depths in the soil profile as well as the steep temperature gradient with depth, both of which are due to the low thermal conductivity of soil. Also notable are the greatly increased temperatures and durations under the high fuel loads and/or more intense fires. Wells et al. (1979) give the following reasons why soil temperatures generated during a shrubland (chaparral) fire usually exceed those during prescribed burns in forests:

(i) more of the shrubland fuel is on the ground,

(ii) burns in forests are usually implemented under moister conditions, and

(iii) shrublands are likely to have less insulating organic material on the ground. 


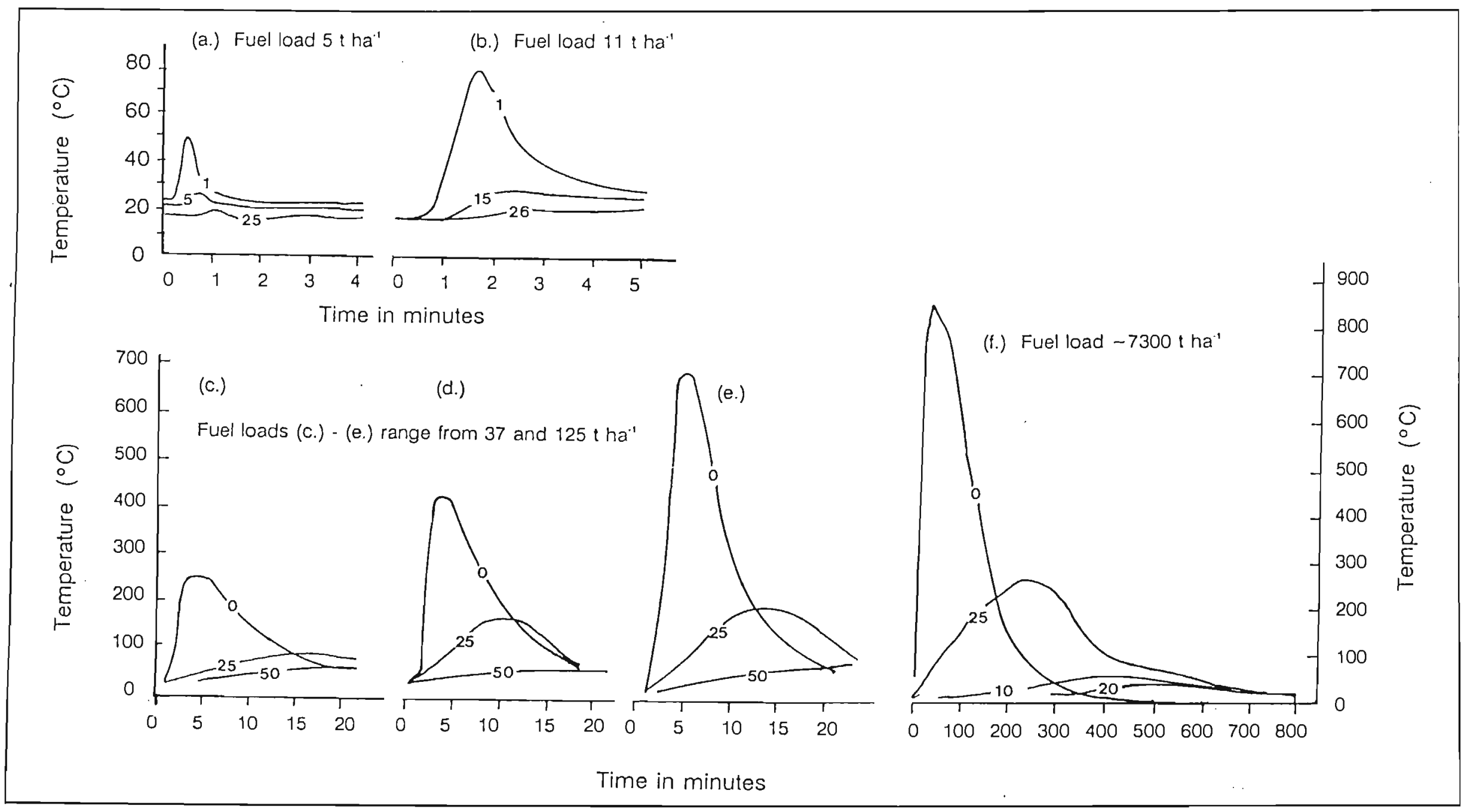

Figure 2.2 Temperature-time curves at various depths $(\mathrm{mm})$ in the soil beneath (a) moderate and (b) high intensity grassland burns in New South Wales (Norton and McGarrity, 1965), (c) light (d) moderate and (e) intense burns in Californian chaparral on dry soils (DeBano et al., 1977), and (f) eucalypt slash pile burn in New South Wales (Humphreys and Lambert, 1965). 
Conditions for fire in forests and timber plantations are highly variable, and ultimately soil temperatures will depend on fire intensity, the amount of insulating organic material on the soil surface and on soil wetness. Where management operations have concentrated fuels into slash piles the risk of high fire intensities will be greatest.

\subsubsection{The effect of fire on soil erodibility}

Numerous studies report an increase in soil erosion rates following fire in forest, shrubland and grassland sites (Wells et al., 1979), yet few are specific as to the cause of the increased erosion rate. Two of the primary variables which control erosion rates, namely vegetal cover (including canopy and ground cover) and the soil's intrinsic erodibility, are affected by fire. Several studies, for example by Mersereau and Dyrness (1972) and Campbell et al. (1977), have indicated that a reduction in erosion rates is associated with recovery of vegetal cover. Plant litter on the soil surface improves conditions for infiltration and reduces surface runoff (Lowdermilk, 1930).

Certain soils, when exposed to extreme heating, are capable of being baked to a state of improved aggregation with improved hydraulic properties (Scott and Burgy, 1955). More usually severe heating of the soil will increase its erodibility (DeBano, 1981; Giovannini and Lucchesi, 1983; Watson and Poulter, 1987). The mechanism for this action seems to be the combustion of organic matter which is incorporated in the soil, where it is important in aiding micro-aggregation of the soil. Temperatures as low as $250^{\circ} \mathrm{C}$ can break down organic matter (Hosking, 1938) and result in a soil which is powdery and friable. Soil left more erodible by the passage of a fire will be prone to increases in erosion by wind, gravity, raindrop impact and surface wash.

\subsubsection{Fire-induced water repellency}

Soils are usually completely wettable; water repellency is an abnormality in soils resulting from the coating of soil particles with hydrophobic organic substances which reduce the attraction between soil particles and water (DeBano et al., 1967). The source of these hydrophobic substances is undecomposed and decomposed plant materials present in the soil (Savage et al., 1972). The degree of repellency is related positively to the age of the vegetation, and hence time of contact between plant litter and soil (Teramura, 1980). Finally, soil heating, such as may occur during fire, has been found to intensify water repellency in the soil (DeBano and Krammes, 1966; Dyrness, 1976; John, 1978; WJ Bond, 
1989, personal communication ${ }^{1}$ ). Fire-induced water repellency in soils has been observed mostly in chaparral areas in southern California (Krammes and DeBano, 1965; DeBano and Krammes, 1966; DeBano et al., 1970), but also in the states of Montana, Arizona, Oregon and Michigan (respectively, DeByle, 1973; Salih et al., 1973; Scholl, 1975; Dyrness, 1976; McNabb et al., 1989; and Reeder and Jurgensen, 1979) as well as in New Zealand, Australia and Chile (John, 1978; Leitch et al., 1983; Ellies, 1983, respectively).

Work by DeBano, Krammes, Savage and Scholl on fire-induced repellency in California and Arizona (Krammes and DeBano, 1965; DeBano, 1966; DeBano and Krammes, 1966; Savage et al., 1969; DeBano et al., 1970; Savage, 1974; Scholl, 1975; DeBano et al., 1976) has provided a good model of the process involved. Sufficient heating of the soil during a fire may denature or vaporise the existing hydrophobic organic coatings (Krammes and DeBano, 1965; DeBano, 1966) leaving the surface soil wettable. Krammes and DeBano (1965) found that both temperature and the duration of heating were important factors, and that, for instance, temperatures in excess of $300^{\circ} \mathrm{C}$ for 30 minutes would remove a hydrophobic effect. Where less heating occurs incipient repellency can be intensified (Krammes and DeBano, 1965; DeBano, 1966). Also, vaporised repellent substances from overlying soil and litter layers can move downward in the soil profile, in response to a temperature gradient, and there distil onto the soil particles (DeBano, 1966), thereby thickening the band of repellency in the soil (Figure 2.3). Dyrness (1976) reported water repellent soils as resulting from a wildfire in a lodgepole pine forest in the Cascade Mountains in Oregon, where the degree of water repellency was positively related to the severity of the fire. Savage (1974) postulates that, through heating, the aliphatic hydrocarbons responsible for repellent effects become polar and thus strongly bonded to the soil particles. Deeper in the soil profile, heating by the fire may not be sufficient to have any effect on the wettability of the soil (DeBano, 1966; Figure 2.3).

This process of fire-induced repellency outlined here and illustrated in Figure 2.3 produces a distinctly layered wettability in affected soil profiles. "Dusty footprints in the mud", a phenomenon observed by American researchers, aptly describes the obviously layered repellency in the field after rain on a burned site, where wet surface soil came away on one's boots exposing dusty dry soil immediately below (DeBano, 1981). The descriptive term "tin-roof effect" was coined by American researchers to describe this situation of layered wettability, where water runs out of the saturated surface layer in an exposed soil profile and over the dry sub-surface layer without wetting it (DeBano, 1981). 


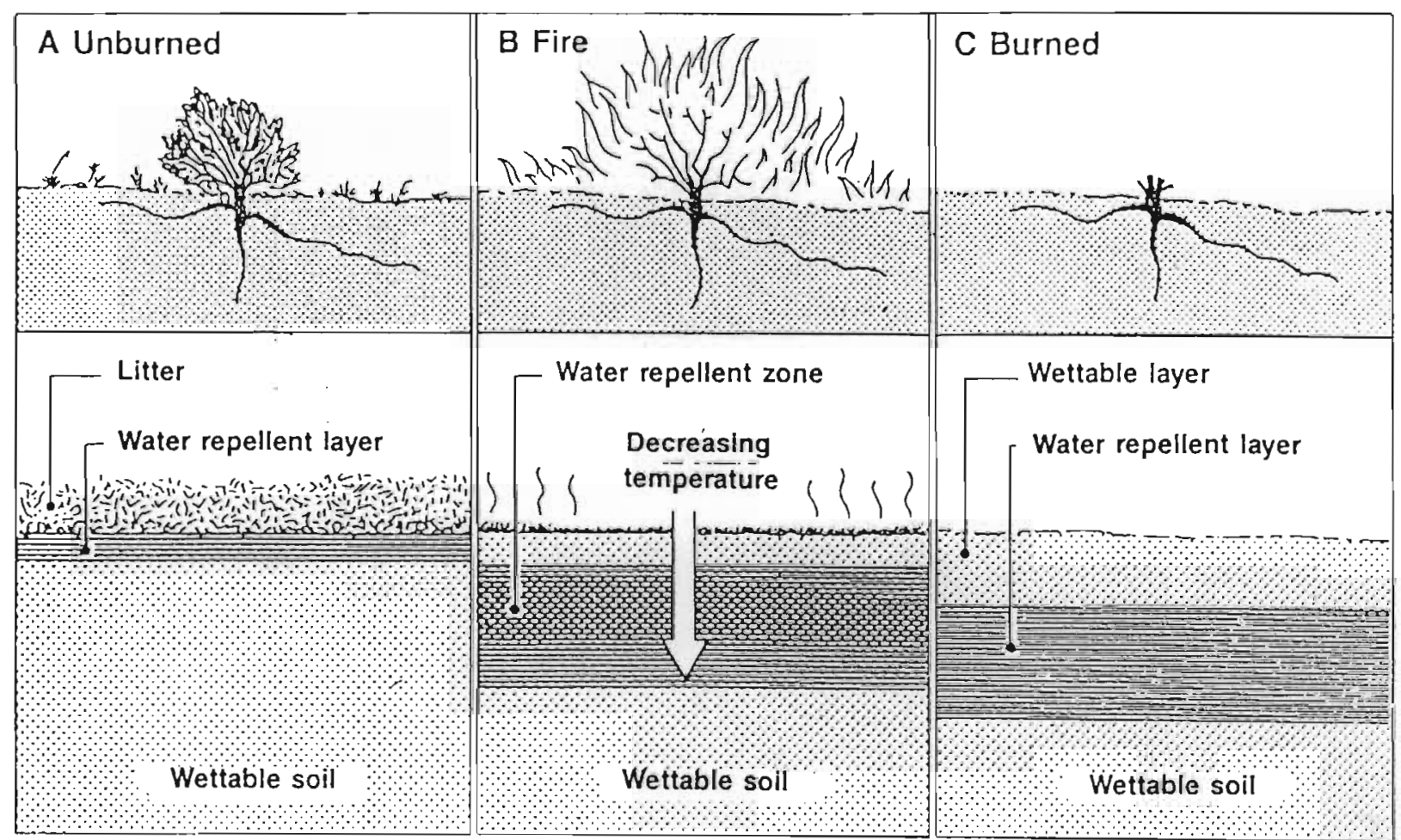

Figure 2.3 Water repellency in soil as altered by fire: (a) before fire hydrophobic substances accumulate in the litter layer and in the mineral soil immediately beneath it; (b) during fire the surface layer is heated, destroying some repellent substances while others are volatilised and move downward into the soil profile along a temperature gradient; and (c) after a fire the water repellent layer is below and parallel to the soil surface (DeBano, 1969b).

\subsubsection{The implications of water repellent soils}

Water repellency is important because it affects

(i) the hydraulic properties of the soil, and thereby the distribution of water and its availability to plant roots, and

(ii) as a consequence of (i) the hydrological behaviour of the entire catchment.

The most obvious effect of water repellent soils is that they impede infiltration and percolation in the soil, which may result in the generation of overland flow (Jamison, 1947; DeBano, 1969a and 1971) and the restriction of percolation to preferred pathways in the soil profile (Burch et al., 1989; Van Dam et al., 1990). Preferred paths may be wettable zones or macro-pores in the soil profile, or they may be channels or rills on the surface. Gullying, resulting from increased overland flow, may be associated with vegetation types causing water repellent soils (McGhie, 1981). In an unburned eucalypt forest in Australia, 
soils which were water repellent during the dry season caused greater runoff from the forest relative to an adjacent grassland, while the reverse was the case when the soils were wettable (Burch et al., 1989). Repellency causes patchy wetting of the soil profile, and despite a considerable amount of rainfall, blocks of soils near the surface may remain markedly dry (Adams et al., 1969; Van Dam et al., 1990). Hydraulic conductivity of the soil will also be reduced (DeBano, 1971; Bishay and Bakhati, 1976; Van Dam et al., 1990).

Water repellent soil which, as a consequence, is abnormally dry may inhibit seed germination and also reduce the chances of seedling survival, preventing colonisation of these soils by plants (Osborn et al., 1967; Adams et al., 1969). This may be the ecological "purpose" of water repellent soils; to act in the same way as allelopathy to reduce competition close to the parent plant.

Dyrness (1976) reported water repellency following fire in a lodgepole pine forest in the Cascade Mountains in Oregon. Repellency increased with "severity" of the fire, and reduced the infiltration rate of the soil. Impeded infiltration and percolation (as a result of water repellent soils) may lead to the changed hydrological behaviour of a catchment because more rainfall reaches the stream as overland flow or rapid interflow. This mechanism is illustrated in Figure 2.4, which also shows that the repellent layer is not continuous, allowing some percolation to deeper depths.

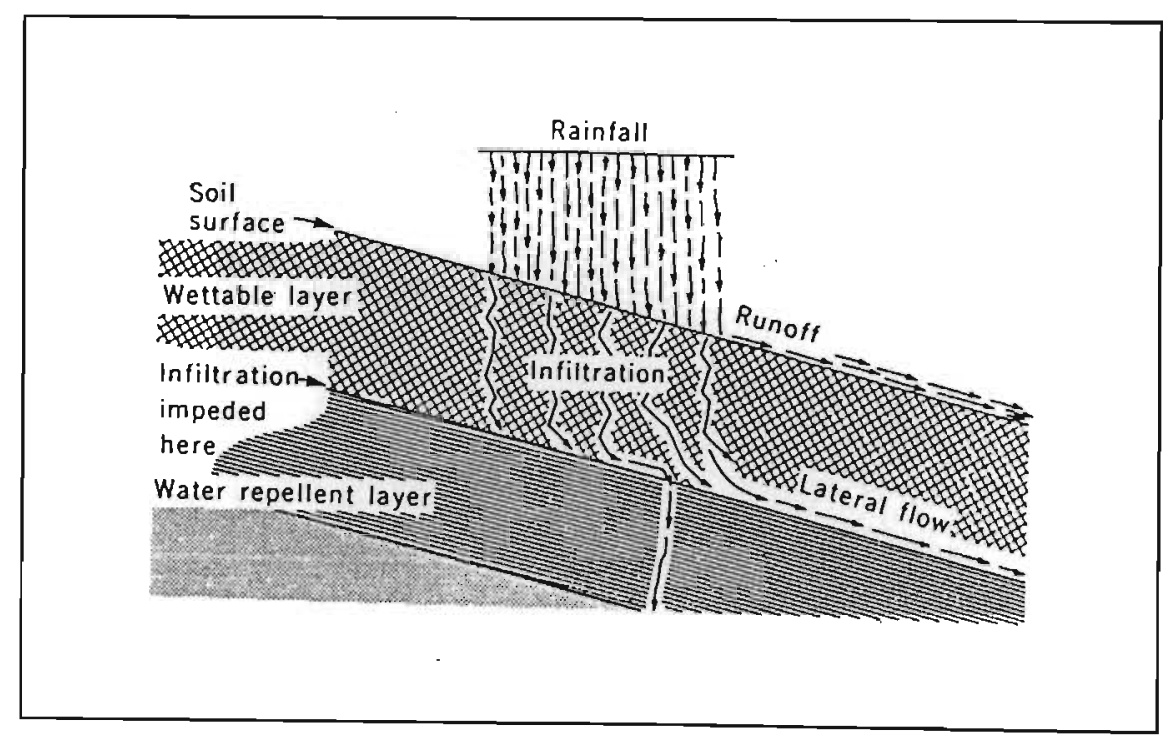

Figure 2.4 Idealised sketch of how a water repellent soil below the soil surface impedes percolation and may lead to saturation overland flow (DeBano, 1969c). 
Osborn et al. (1964) showed experimentally that fire-induced repellency in the soil increased overland flow and soil loss on small plots. A "severe" burn in a ponderosa pine forest in Arizona induced repellency in the soil and reduced its infiltration rate by $66 \%$ (Campbell et al., 1977). This was associated with an $800 \%$ increase in stream-flow and a $450 \%$ increase in "runoff efficiency" from the catchment in the first wet season following the fire. Water repellent soils were also associated with wildfire-initiated flooding and erosion from a eucalypt afforested area in the Victorian Central Highlands of Australia (Leitch et al., 1983). It was estimated that roughly $22 \mathrm{t}$ ha' of soil was eroded from the burned site and that losses of nitrogen and phosphorus, through erosion and volatilisation, amounted to roughly one third of the previously available quantities.

\subsection{FORMULATION OF AN HYPOTHESIS AND RESEARCH PLAN}

Based on the above literature review and observations of a wildfire site, it was hypothesised that the occasionally marked hydrological effects of fire in South African catchments, such as those recorded by Rycroft (1947) in Jonkershoek, could be linked to the presence of fire-induced repellency in the soils. By inhibiting infiltration and/or percolation in a burned catchment, water repellent soils, though unlikely to be continuous over an entire catchment, could increase the probability of overland flow and hence the amount of energy available for soil erosion. Through an increased contribution of overland flow to the channel flow, greater storm-flow volumes and peak discharges would result. Soil losses on the hill-slopes and sediment yields from the catchment would be increased in response to the greater erosive forces in the catchment.

The following research plan was therefore drawn up to test the above hypothesis for hydrological responses to fire:

(i) at the catchment scale, to quantify the responses, if any, of some stream-flow variables to fire, and to contrast these responses (in one catchment) to responses to clear-felling;

(ii) at the intermediate (i.e. hill-slope) scale, overland flow plots would be used to measure the generation of overland flow and soil loss on hill-slopes in the burned catchments to confirm that infiltration was impeded and that overland flow was the likely cause of increased storm-flows and some of the soil loss, and

(iii) at the point (i.e. at the level of the soil profile) scale, to determine whether the 
wettability of the soils of the burned catchments could be related to fire, and hence to any effect which may be seen on the overland flow plots.

(iv) Finally, in order to extrapolate the results of this study, an attempt would be made to determine the prevalence (i.e. risk) of non-wettable soils in mountain catchments and forestry sites in South Africa, and a rainfall simulator would be used to replicate fire treatments in additional forestry areas.

It was thus decided to undertake this project at the three scales of catchment, small overland flow plot and soil profile all within a single catchment in an effort to link the wettability of soils to the observed hydrological behaviour of the catchment.

In the next chapter the gauged research catchments in which the effects of fire were studied are described along with the research methods which were common to each study. 
Table 2.1 Summary of catchment scale hydrological responses to fire.

\begin{tabular}{|c|c|c|c|c|c|c|c|}
\hline Catchment and location & $\begin{array}{l}\text { Area } \\
\text { (ha) }\end{array}$ & $\begin{array}{c}\text { MAP } \\
\text { (MAR) } \\
\text { mm }\end{array}$ & Description & Treatment & Stream-flow responses & $\begin{array}{l}\text { Sediment yleld responses } \\
\text { (t ha"-1 unless specified) }\end{array}$ & Reference \\
\hline \multicolumn{8}{|l|}{ South Africa } \\
\hline $\begin{array}{l}\text { 1. Abdolskoof, } \\
\text { Jonkershoek, SW Cape }\end{array}$ & 12 & $\begin{array}{r}1275 \\
(385)\end{array}$ & $\begin{array}{l}\text { Deep gravelly loams; } \\
\text { mountain fynbos }\end{array}$ & $\begin{array}{l}\text { High intensity wildfire } \\
\text { (Apr. 1945) }\end{array}$ & $\begin{array}{l}\text { TF \& PF: } 133 \% \text { \& } 400 \% \\
\text { increases in } 1 \text { st wet season } \\
\text { respectively }\end{array}$ & & $\begin{array}{l}\text { Rycroft 1947; } \\
\text { Van Wyk } 1987\end{array}$ \\
\hline $\begin{array}{l}\text { 2. Kasteelskloof and } \\
\text { Zachariashoek, SW } \\
\text { Cape }\end{array}$ & $\begin{array}{l}324 \\
287\end{array}$ & $\begin{array}{l}1443 \\
(694) \\
1003 \\
(379)\end{array}$ & $\begin{array}{l}\text { Quartzitic sandstones; } \\
\text { shallow to deep sandy } \\
\text { loams; mountain fynbos }\end{array}$ & $\begin{array}{l}\text { Prescribed burns at } 6 \text { and } \\
12 \text { year cycles }\end{array}$ & $\begin{array}{l}\text { IF: increases of up to } 85 \\
\mathrm{~mm}(15 \%) \text { in first year } \\
\text { reducing to zero by } 4 \text { th } \\
\text { year }\end{array}$ & $\begin{array}{l}\text { SS: up to } 0.97 \times 10^{-3} \text { in } 1 \mathrm{st} \\
\text { year B: } 6-7 \times 10^{-3} ; \text { sediment } \\
\text { yields normal within } 10 \\
\text { months }\end{array}$ & $\begin{array}{l}\text { Van Wyk 1982; } \\
\text { Lindley et al. } \\
1988\end{array}$ \\
\hline $\begin{array}{l}\text { 3. Langrivier, Jonkershoek, } \\
\text { SW Cape }\end{array}$ & 246 & $2261(1603)$ & $\begin{array}{l}\text { Deep gravelly loams; } \\
\text { overmature mountain } \\
\text { fynbos }\end{array}$ & $\begin{array}{l}\text { Wildfire at the end of the } \\
\text { wet season (Oct. 1987) }\end{array}$ & , & $\begin{array}{l}\text { SS: } 0.148 ; \text { sediment yield } \\
\text { normal by the first wet } \\
\text { season }\end{array}$ & $\begin{array}{l}\text { Van Wyk and } \\
\text { Lesch } 1989\end{array}$ \\
\hline $\begin{array}{l}\text { 4. Cathedral Peak, } \\
\text { Drakensberg, Natal }\end{array}$ & 44,139 & $1257-1564$ & $\begin{array}{l}\text { Dense short grasslands; } \\
\text { soils as for } 5 \text {. below }\end{array}$ & $\begin{array}{l}\text { Various wildfires and } \\
\text { prescribed burns }\end{array}$ & $\begin{array}{l}\text { Low flows unaffected by } \\
\text { burning }\end{array}$ & & Nänni, 1960 \\
\hline $\begin{array}{l}\text { 5. Cathedral Peak, } \\
\text { Drakensberg, Natal }\end{array}$ & $\begin{array}{c}72,95 \\
139 \\
64\end{array}$ & $\begin{array}{l}1427 \\
1564 \\
1257\end{array}$ & $\begin{array}{l}\text { Deep basalts; clay loam } \\
\text { soils; moderate to steep } \\
\text { slopes }\end{array}$ & $\begin{array}{l}\text { 1. Biennially burned } \\
\text { grassland } \\
\text { 2. Wildfire in pine } \\
\text { plantation } \\
\text { 3. Unburned grassland }\end{array}$ & $\begin{array}{l}\text { TF: no change } \\
\text { SF: minor increases } \\
\text { Not measured on account } \\
\text { of high sedimentation } \\
\text { damage } \\
\text { TF: no change }\end{array}$ & $\begin{array}{l}\text { SY: } 1.8 \\
\text { SYY: at least } 37 \text { in 1st year } \\
\text { SY: } 0.4\end{array}$ & $\begin{array}{l}\text { Bosch, 1980; } \\
\text { Bosch et al. } \\
1984 \text {; Van Wyk, } \\
1986\end{array}$ \\
\hline \multicolumn{8}{|l|}{ Australla } \\
\hline $\begin{array}{l}\text { 5. Yarrangobilly River and } \\
\text { Wallaces Creek, SE } \\
\text { NSW }\end{array}$ & $\begin{array}{r}22450 \\
4310\end{array}$ & $\begin{array}{l}(0.520) \\
(c .550)\end{array}$ & $\begin{array}{l}\text { All-year rainfall; wet to dry } \\
\text { eucalypt forests }\end{array}$ & $\begin{array}{l}\text { High intensity wildfire } \\
\text { (March 1965) }\end{array}$ & $\begin{array}{l}\text { TF \& PF: large Increases. A } \\
\text { sharp additional peak in } \\
\text { storm hydrographs }\end{array}$ & $\begin{array}{l}\text { SS: } 25000 \text { and } 100000 \% \\
\text { increases in peak sediment } \\
\text { loads; recovery within } 2 \text { years }\end{array}$ & Brown 1972 \\
\hline 6. Kosciusko N.P., NSW & & c. 500 & $\begin{array}{l}\text { Alpine and sub-alpine } \\
\text { forest and shrubland }\end{array}$ & $\begin{array}{l}\text { Mid-summer wildfires } \\
\text { after long dry periods }\end{array}$ & & $\begin{array}{l}\text { SS: } 250-350 \% \text { increases at } \\
\text { peak discharge }\end{array}$ & Good 1973 \\
\hline
\end{tabular}




\begin{tabular}{|c|c|c|c|c|c|c|c|}
\hline Catchment and location & $\begin{array}{l}\text { Area } \\
\text { (ha) }\end{array}$ & $\begin{array}{l}\text { MAP } \\
\text { (MAR) } \\
\text { mm }\end{array}$ & Descriptlon & Treatment & Stream-flow responses & $\begin{array}{l}\text { Sediment yleld responses } \\
\text { (t ha' } a^{\prime \prime} \text { unless specifled) }\end{array}$ & Reference \\
\hline \multicolumn{8}{|l|}{ Australia continued... } \\
\hline $\begin{array}{l}\text { 7. } 7 \text { large catchments, } \\
\text { Southern Highlands, } \\
\text { Victoria }\end{array}$ & $\begin{array}{l}1430- \\
12800\end{array}$ & c. 1450 & $\begin{array}{l}\text { Deep clay loams; high } \\
\text { (70m) Eucalyptus regnans } \\
\text { forest }\end{array}$ & $\begin{array}{l}\text { High intensity wildfire } \\
\text { (Jan. 1939) }\end{array}$ & $\begin{array}{l}\text { IF: reductions in flow } \\
\text { averaging } 214 \mathrm{~mm}(24 \%) \text { for } \\
21 \text { years. }\end{array}$ & & Langford 1976 \\
\hline 8. Eden, NSW & & c. .900 & $\begin{array}{l}\text { Grey sandy loams; dry } \\
\text { sclerophyllous forest }\end{array}$ & $\begin{array}{l}\text { Mid-summer wildfire, } \\
\text { after long dry period }\end{array}$ & $\begin{array}{l}\text { SF: Increased by } 100 \text { - } \\
300 \% \text {. } \\
\text { PF: increased by } 100- \\
900 \% \text {. Efrects dependent } \\
\text { on \% area burned and } \\
\text { severity of burn. }\end{array}$ & & $\begin{array}{l}\text { MacKay and } \\
\text { Cornish } 1982\end{array}$ \\
\hline 9. Bushrangers, ACT & 97.5 & 1230 & $\begin{array}{l}\text { Deep soils; all year rainfall; } \\
\text { sub-alpine forest }\end{array}$ & $\begin{array}{l}\text { High intensity prescribed } \\
\text { fire }\end{array}$ & $\begin{array}{l}\text { Summer base-flow } \\
\text { increased by } 32 \mathrm{~mm} \\
(106 \%) \text { in 1st year only. }\end{array}$ & & $\begin{array}{l}\text { O'Loughlin et al. } \\
1982\end{array}$ \\
\hline $\begin{array}{l}\text { 10. Warburton, Victorian } \\
\text { Central Highlands }\end{array}$ & 35 & & $\begin{array}{l}\text { Shallow, gravelly loams; } \\
\text { mixed eucalypt forest; } \\
\text { moderately steep slopes. }\end{array}$ & $\begin{array}{l}\text { High intensity wildfire in } \\
\text { late summer }\end{array}$ & $\begin{array}{l}\text { PF: estimated maximum of } \\
51 \cdot 103 \mathrm{~mm} \mathrm{~h} \mathrm{~h}^{-1} \text { from } \\
\text { single, } 17 \mathrm{~mm} \text {, storm }\end{array}$ & $\begin{array}{l}\text { SY: estimated net loss of } 22 \mathrm{t} \\
\text { ha" from single storm }\end{array}$ & Leitch et al. 1983 \\
\hline \multicolumn{8}{|l|}{ USA } \\
\hline $\begin{array}{l}\text { 11. Montrose - La } \\
\text { Crescenta, California }\end{array}$ & & & Mountain chaparral & $\begin{array}{l}\text { Wildfire followed by } \\
\text { severe ralnstorm }\end{array}$ & & $\begin{array}{l}\text { SY: estimated } 306 \mathrm{tha} \text { ' from } \\
\text { the single event }\end{array}$ & Colman 1951 \\
\hline 12. Yucaipa, California & 253 & & Mountain chaparral & $\begin{array}{l}\text { Wildfire in July; high } \\
\text { intensity thunderstorm }\end{array}$ & & $\begin{array}{l}\text { SY: estimated } 25 \text { tha. from } \\
\text { the single event }\end{array}$ & Colman 1951 \\
\hline $\begin{array}{l}\text { 13. Wheeler Springs Fire, } \\
\text { California }\end{array}$ & 10625 & & Chaparral & Wildfire (1948) & no floods & little erosion & Colman 1951 \\
\hline $\begin{array}{l}\text { 14. San Gabriel } \\
\text { Mountains, California }\end{array}$ & & & Steep slopes; chaparral & Fire & $\begin{array}{l}\text { PF: increases of between } \\
100 \cdot 4400 \% \text {, depending on } \\
\text { storm size, in 1st year. }\end{array}$ & & Rowe ot al. 1954 \\
\hline
\end{tabular}




\begin{tabular}{|c|c|c|c|c|c|c|c|}
\hline Catchment and location & $\begin{array}{c}\text { Area } \\
\text { (ha) }\end{array}$ & $\begin{array}{c}\text { MAP } \\
\text { (MAA) } \\
\text { mm }\end{array}$ & Descriptlon & Treatment & Stream-flow responses & $\begin{array}{l}\text { Sediment yleld responses } \\
\text { (t ha" a" unless specified) }\end{array}$ & Reference \\
\hline \multicolumn{8}{|l|}{ USA continued... } \\
\hline $\begin{array}{l}\text { 15. Wilson River, } \\
\text { Tillamook Burns, } \\
\text { Oregon }\end{array}$ & 40800 & & $\begin{array}{l}\text { Temperate; coastal rain- } \\
\text { forest }\end{array}$ & $\begin{array}{l}\text { Three wildfires between } \\
1933 \text { and } 1945\end{array}$ & $\begin{array}{l}\text { TF: increase of } 229 \mathrm{~mm} \mathrm{a}^{-1} \\
\text { (c. } 11 \%) \text { over } 15 \text { years; } \\
\text { base-flows Increased by } \\
16 \% \text {. } \\
\text { PF: } 45 \% \text { higher } \\
\text { immediately after fire, } \\
\text { declining over } 8 \text { years. }\end{array}$ & $\begin{array}{l}\text { SY: } 400-700 \% \text { increase, } 3 \mathrm{t} \\
\mathrm{ha}^{\prime \prime} \mathrm{a}^{-1} 17 \text { years after first fire }\end{array}$ & Anderson 1976 \\
\hline $\begin{array}{l}\text { 16. Burns Watershed, } \\
\text { Washington State }\end{array}$ & & $\begin{array}{l}579(112- \\
175)\end{array}$ & & $\begin{array}{l}\text { Wildfire in summer (Aug. } \\
\text { 1970) }\end{array}$ & $\begin{array}{l}\text { TF: increase over the 1st } 3 \\
\text { years of about } 200 \mathrm{~mm} \mathrm{a."} \\
(120 \%)\end{array}$ & $\begin{array}{l}\text { SY: Massive debris, rock and } \\
\text { soil flows }\end{array}$ & $\begin{array}{l}\text { Helvey et al. } \\
1976\end{array}$ \\
\hline $\begin{array}{l}\text { 17. Rattle Burn, Coconino } \\
\text { N.F., Arizona }\end{array}$ & 8.1 & c.737 & $\begin{array}{l}\text { Stoney soils; }<20 \% \\
\text { slopes; open pine forest }\end{array}$ & $\begin{array}{l}\text { High intensity wildfire } \\
\text { (May 1972) }\end{array}$ & $\begin{array}{l}\text { TF: } 700 \text { and } 280 \% \\
\text { increases in } 1 \text { st } \& \text { 2nd } \\
\text { years. Response increased } \\
357 \%, \text { to } 3.8 \% \text { of ralnfall }\end{array}$ & $\begin{array}{l}\text { SY: } 1.7 \text { t ha }{ }^{-1}(c .40000 \% \\
\text { increase) in first } 2 \text { years }\end{array}$ & $\begin{array}{l}\text { Campbell et al. } \\
1977\end{array}$ \\
\hline $\begin{array}{l}\text { 18. Three Bar Watersheds, } \\
\text { Arizona }\end{array}$ & & $620-750$ & $\begin{array}{l}\text { Deep, coarse soils; sparse } \\
\text { deep-rooted chaparral }\end{array}$ & Wildfire (June 1959) & $\begin{array}{l}\text { TF: } 276 \mathrm{~mm} \text { (900\%) } \\
\text { increase in 1st year } \\
\text { Base-flows increased }\end{array}$ & & $\begin{array}{l}\text { Pase and Ingebo } \\
1965\end{array}$ \\
\hline
\end{tabular}

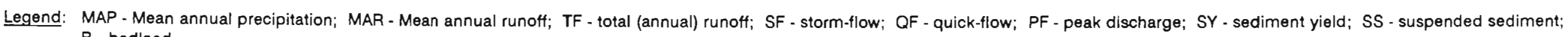
$B$ - bedload. 
Table 2.2 Summary of measurements of overland flow and sediment yield from plots.

\begin{tabular}{|c|c|c|c|c|c|c|c|c|}
\hline Location & $\begin{array}{l}\text { Plot } \\
\text { size }\end{array}$ & $\begin{array}{l}\text { MAP } \\
(\mathrm{mm})\end{array}$ & Description & Treatment & $\begin{array}{l}\text { Overland flow } \\
\text { (as \% of } \\
\text { rainfall) }\end{array}$ & $\begin{array}{l}\text { Sediment yield } \\
\left(t \mathrm{ha}^{-1} \mathrm{a}^{-1}\right)\end{array}$ & Notes & Reference \\
\hline \multicolumn{9}{|l|}{ South Africa } \\
\hline $\begin{array}{l}\text { 1. Ntabamhlope, } \\
\text { Natal }\end{array}$ & $1 \times 23 \mathrm{~m}$ & 718 & $\begin{array}{l}\text { Clay loams; } \\
\text { slopes of } 8 \% \text {; dense } \\
\text { sub-tropical grassland }\end{array}$ & $\begin{array}{l}\text { Unburnt } \\
\text { Annual winter burn }\end{array}$ & $\begin{array}{l}12.6 \\
9.2\end{array}$ & $\begin{array}{l}0.088 \\
0.514\end{array}$ & $\begin{array}{l}\text { Seven year } \\
\text { averages; high } \\
\text { runoff due to } \\
\text { thatching effect }\end{array}$ & Scott 1951 \\
\hline $\begin{array}{l}\text { 2. Jonkershoek, } \\
\text { SW Cape }\end{array}$ & 0.08 ha & 1156 & $\begin{array}{l}\text { Deep sandy loams; } \\
25 \% \text { slope; fynbos and } \\
\text { pine }\end{array}$ & $\begin{array}{l}\text { Various, including hoe } \\
\text { and burn }\end{array}$ & $\begin{array}{l}\text { Mean } 0.01- \\
0.07 \% ; \max \\
0.65 \%\end{array}$ & Negligible & $\begin{array}{l}\text { No treatment } \\
\text { effects }\end{array}$ & Versfeld 1981 \\
\hline $\begin{array}{l}\text { 3. Bosboukloof, } \\
\text { Jonkershoek, } \\
\text { SW Cape }\end{array}$ & $3 \times 18 \mathrm{~m}$ & 1296 & $\begin{array}{l}\text { Deep sandy loams; } \\
29-62 \% \text { slopes; } \\
\text { pine plantation }\end{array}$ & $\begin{array}{l}\text { Late summer (dry } \\
\text { season) } \\
\text { wildfire }\end{array}$ & & 9.9 to 25.9 & $\begin{array}{l}\text { Increasing with } \\
\text { slope }\end{array}$ & $\begin{array}{l}\text { Scott and Van } \\
\text { Wyk } 1990\end{array}$ \\
\hline \multicolumn{9}{|l|}{ Australia } \\
\hline 4. Canberra, ACT & $\begin{array}{c}.0006 \\
\text { ha }\end{array}$ & $\begin{array}{l}\text { Simulated } \\
\text { rain }\end{array}$ & $\begin{array}{l}7 \% \text { slope; Pinus radiata } \\
\text { plantation }\end{array}$ & $\begin{array}{l}\text { Prescribed fire; rain of } \\
20 \mathrm{~mm} \text { at } 80 \mathrm{~mm} \mathrm{~h}^{.1}\end{array}$ & & None & $\begin{array}{l}\text { Non-significant } \\
\text { decrease in } \\
\text { infiltration }\end{array}$ & $\begin{array}{l}\text { Gilmour and } \\
\text { Cheney } 1968\end{array}$ \\
\hline $\begin{array}{l}\text { 5. Narrabeen } \\
\text { Lagoon, NSW }\end{array}$ & $2 \times 4 \mathrm{~m}$ & c. 1200 & $\begin{array}{l}\text { Deep sandy topsoil; } \\
21 \% \text { slope; dry forest }\end{array}$ & $\begin{array}{l}\text { Moderate intensity } \\
\text { wildfire }\end{array}$ & $\begin{array}{l}\text { Mean } 3-5 \% \\
\max 9.6 \%\end{array}$ & $2.5-8.2$ & $\begin{array}{l}40 \% \text { of soil loss } \\
\text { from } 1 \text { event }\end{array}$ & $\begin{array}{l}\text { Blong et al. } \\
1982\end{array}$ \\
\hline $\begin{array}{l}\text { 6. Royal National } \\
\text { Park, Sydney, } \\
\text { NSW }\end{array}$ & & $\begin{array}{l}340 \text { in } 3 \\
\text { months }\end{array}$ & $\begin{array}{l}\text { Shallow sandy soils; } 6 \text { - } \\
13 \% \text { slopes; dry } \\
\text { bushland }\end{array}$ & $\begin{array}{l}\text { High intensity wildfire } \\
\text { (Jan. 1983) }\end{array}$ & & $\begin{array}{l}30-48 \text { in } 3 \\
\text { months }\end{array}$ & $\begin{array}{l}35 \% \text { organics in } \\
1 \text { st debris }\end{array}$ & Atkinson 1984 \\
\hline $\begin{array}{l}\text { 7. Wallaby Creek, } \\
\text { NE Victoria }\end{array}$ & .002 ha & 1220 & $\begin{array}{l}\text { Stoney clay loams; } \\
36 \% \text { slope; dry forest }\end{array}$ & $\begin{array}{l}\text { Hot prescribed fuel- } \\
\text { reduction burns }\end{array}$ & $\begin{array}{l}\text { Doubled to } \\
2.5 \% \text { after high } \\
\text { intensity burn }\end{array}$ & $\begin{array}{l}\text { Doubled to } 0.1- \\
0.35\end{array}$ & $\begin{array}{l}\text { Recovery: runoff } \\
3-5 \text { yrs; erosion } \\
1-5 \text { yrs }\end{array}$ & Ronan 1986 \\
\hline
\end{tabular}




\begin{tabular}{|c|c|c|c|c|c|c|c|c|}
\hline Location & $\begin{array}{l}\text { Plot } \\
\text { size }\end{array}$ & $\begin{array}{l}\text { MAP } \\
(\mathrm{mm})\end{array}$ & Description & Treatment & $\begin{array}{l}\text { Overland flow } \\
\text { (as \% of } \\
\text { rainfall) }\end{array}$ & $\begin{array}{l}\text { Sediment yield } \\
\left(t h a^{-1} a^{-1}\right)\end{array}$ & Notes & Reference \\
\hline \multicolumn{9}{|l|}{ Americas } \\
\hline $\begin{array}{l}\text { 8. North Fork, } \\
\text { Madera Co., } \\
\text { California }\end{array}$ & $3 \times 33 \mathrm{~m}$ & 840 & $\begin{array}{l}\text { Deep sandy clay } \\
\text { loams; } 36 \% \text { slope; } \\
\text { chaparral-woodland }\end{array}$ & $\begin{array}{l}\text { 1. undisturbed } \\
\text { 2. twice burned } \\
\text { 3. annually burned }\end{array}$ & $\begin{array}{c}0.04 \% \\
1.87 \% \\
14.2 \%\end{array}$ & $\begin{array}{l}0.014 \\
9.1 \\
257\end{array}$ & $\begin{array}{l}\text { Averaged over } 9 \\
\text { years; majority of } \\
\text { yields in 1st year }\end{array}$ & $\begin{array}{l}\text { Rowe (in } \\
\text { prep.) cited by } \\
\text { Adams et al. } \\
1947\end{array}$ \\
\hline $\begin{array}{l}\text { 9. San Gabriel } \\
\text { Mountains, } \\
\text { California }\end{array}$ & Various & & $\begin{array}{l}\text { Non-cohesive soils; } 55- \\
95 \% \text { slopes; unburned } \\
\text { chaparral }\end{array}$ & $\begin{array}{l}\text { No treatment: base-line } \\
\text { measurements }\end{array}$ & & $0.4-7.8$ & $\begin{array}{l}\text { Majority as dry } \\
\text { ravel }\end{array}$ & $\begin{array}{l}\text { Anderson et } \\
\text { al. } 1959\end{array}$ \\
\hline $\begin{array}{l}\text { 10. Twelve } \\
\text { contrasting } \\
\text { areas in USA }\end{array}$ & $\begin{array}{l}0.004- \\
2.2 \text { ha }\end{array}$ & $500-1750$ & $\begin{array}{l}\text { Humid sites suitable for } \\
\text { agriculture; } \\
2-30 \% \text { slopes }\end{array}$ & $\begin{array}{l}\text { No treatment, plots } \\
\text { under good cover }\end{array}$ & $0.03-13.8$ & $0.22-1.4$ & $\begin{array}{l}\text { Considered to be } \\
\text { natural erosion } \\
\text { rates }\end{array}$ & $\begin{array}{l}\text { Smith and } \\
\text { Stamey } 1965\end{array}$ \\
\hline $\begin{array}{l}\text { 11. W. San Gabriel } \\
\text { and Santa Ana } \\
\text { Mntns, } \\
\text { California }\end{array}$ & & $\begin{array}{l}773 \\
949\end{array}$ & $\begin{array}{l}\text { Gravelly } \\
\text { granitic loams }\end{array}$ & $\begin{array}{l}\text { Wildfire } \\
\text { Wildfire }\end{array}$ & $\begin{array}{l}9.7 \\
9.9\end{array}$ & $\begin{array}{c}346 \\
52\end{array}$ & & $\begin{array}{l}\text { Krammes and } \\
\text { Osborn } 1969\end{array}$ \\
\hline $\begin{array}{l}\text { 12. Los Padres NF, } \\
\text { Santa Maria, } \\
\text { California }\end{array}$ & $3 \times 12 \mathrm{~m}$ & & $\begin{array}{l}\text { Gravelly loams; } 20 \text { \& } \\
50 \% \text { slopes; mature } \\
\text { chaparral }\end{array}$ & $\begin{array}{l}\text { Hot prescrlbed burn, } \\
66 \% \text { of fuel consumed }\end{array}$ & & $\begin{array}{l}2.8 \text { gentle \& } 7.3 \\
\text { steep slopes }\end{array}$ & & $\begin{array}{l}\text { DoBano and } \\
\text { Conrad } 1976\end{array}$ \\
\hline $\begin{array}{l}\text { 13. Siguatepeque, } \\
\text { Honduras }\end{array}$ & $1 \times 10 \mathrm{~m}$ & 1130 & $\begin{array}{l}\text { Sandy loams; } \\
\text { high intensity rains; } \\
\text { tropical pine savanna }\end{array}$ & $\begin{array}{l}\text { Low intensity } \\
\text { prescribed burns; } \\
\text { slopes } 18 \text { to } 84 \% \text {; Feb. } \\
\& \text { June burns }\end{array}$ & $\begin{array}{l}5 ; 3 \times \text { control: } \\
\text { negatively } \\
\text { related to slope; } \\
\text { recovery over } 2 \\
\text { years }\end{array}$ & $\begin{array}{l}0.8 ; 20 x \\
\text { control; } \\
\text { Feb. burn } 5 \times \\
\text { June; recovery } 1 \\
\text { yr }\end{array}$ & $\begin{array}{l}\text { Heavy rains in } \\
\text { May; losses } \\
\text { relate to recovery } \\
\text { rates of } \\
\text { vegetation }\end{array}$ & $\begin{array}{l}\text { Hudson et al. } \\
1983\end{array}$ \\
\hline $\begin{array}{l}\text { 14. El Oso Creek, } \\
\text { Arizona }\end{array}$ & Various & & Chaparral & $\begin{array}{l}\text { Wildfire; reduced } \\
\text { canopy to almost zero }\end{array}$ & $3-90 \%$ & $0.005-1.47$ & Semi-arid & $\begin{array}{l}\text { Heede et al. } \\
1988\end{array}$ \\
\hline
\end{tabular}




\section{CHAPTER 3}

\section{DESCRIPTION OF THE CATCHMENTS, TREATMENTS AND METHODS}

The principal studies were undertaken within four gauged research catchments. The first of these catchments was subject to a wildfire and it was observations of the effects of this fire that prompted the initiation of this study. The second catchment was selected as it was to receive a planned experimental burn. The final two catchments burned in wildfires during the course of this study. These were fortuitous events and the catchments were included in the study to broaden the applicability of the findings.

This chapter provides the description of the research catchments (both burned and control) as well as the treatments to which they were subjected and the common methods used on the four catchments. Three of the catchments are in the Jonkershoek Valley near Stellenbosch in the south-western Cape and the fourth is at Ntabamhlope in the foothills of the Natal Drakensberg. In each catchment a similar research approach was taken and for this reason the common methods are described in this chapter, and only details of methods specific to individual catchments are dealt with in subsequent chapters. In each study different degrees of detail were studied at each scale and there were unique aspects to each study, and thus, for the sake of clarity, the results of each catchment study are treated separately. Chapters 4 to 7 contain descriptions of the catchment specific experiments and results.

\subsection{DESCRIPTION OF THE CATCHMENTS AND TREATMENTS}

The catchments studied are all small (Figures 3.1 and 3.2) and well-watered (mean annual precipitation in excess of $830 \mathrm{~mm}$ ). The Ntabamhlope catchments are less steep, with gentler channel and hill-slopes than the three Jonkershoek catchments. The names and physical features of the four burned catchments and the three gauged catchments which served as control catchments are given in Table 3.1. 
Table 3.1 Summary of the physical features of the research catchments used in this study.

\begin{tabular}{|c|c|c|c|c|c|c|}
\hline Name and location & $\begin{array}{l}\text { Area } \\
\text { (ha) }\end{array}$ & $\begin{array}{c}\text { Elevation } \\
\text { of weir } \\
\text { (m) }\end{array}$ & $\begin{array}{l}\text { Relief } \\
\text { (m) }\end{array}$ & $\begin{array}{c}\text { Mean } \\
\text { channel } \\
\text { slope } \\
(\%)\end{array}$ & $\begin{array}{l}\text { MAP * } \\
(\mathrm{mm})\end{array}$ & $\begin{array}{l}\text { MAR } \\
(\mathrm{mm})\end{array}$ \\
\hline $\begin{array}{l}\text { Swartboskloof, } \\
\text { Jonkershoek }\end{array}$ & 180 & 362 & 833 & 46 & 2270 & 1060 \\
\hline $\begin{array}{l}\text { Tierkloof, } \\
\text { Jonkershoek }\end{array}$ & 157 & 277 & 1230 & 39 & 1810 & 1128 \\
\hline $\begin{array}{l}\text { Langrivier, } \\
\text { Jonkershoek }\end{array}$ & 245 & 369 & 1492 & 59 & 2261 & 1603 \\
\hline $\begin{array}{l}\text { Bosboukloof, } \\
\text { Jonkershoek }\end{array}$ & 200 & 270 & 637 & 13 & 1296 & 593 \\
\hline $\begin{array}{l}\text { Lambrechtsbos-B, } \\
\text { Jonkershoek }\end{array}$ & 65 & 292 & 828 & 26 & 1473 & 531 \\
\hline $\begin{array}{l}\text { V1Ho20 }{ }^{+}, \\
\text {Ntabamhlope }\end{array}$ & 132 & 1424 & 121 & 8 & n.m. & n.m. \\
\hline $\begin{array}{l}\text { V1H028 }{ }^{+}, \\
\text {Ntabamhlope }\end{array}$ & 41 & 1460 & 85 & 11 & 838 & 140 \\
\hline
\end{tabular}

- $\quad$ MAP = mean annual rainfall, MAR = mean annual runoff (from Van Wyk, 1987)

$+\quad$ data from Schmidt and Schulze (1989); catchment V1H028 is nested within V1H020 (Figure 3.2); MAP \& MAR estimated from nine years of record only, $1979-1987 ; 29$ year MAP measured at nearby Ntabamhlope Agricultural Research Station is $1092 \mathrm{~mm}$.

The vegetation of the catchments and their treatments are summarised in Table 3.2. Two of the treated research catchments, Bosboukloof and Ntabamhlope V1H02O, are afforested and both burned in wildfires, in hot conditions, towards the end of the dry season. The other two treated catchments, Swartboskloof and Langrivier are covered in fynbos, the indigenous, fire-maintained climax scrub of the south-western Cape province of South Africa. Swartboskloof burned in a prescribed fire towards the end of the dry season, while Langrivier burned in a wildfire at the end of the wet season.

\subsubsection{The Jonkershoek Catchments}

The location of these research catchments and topography are illustrated in Figure 3.1. The catchments are in Jonkershoek State Forest, in the south-western Cape region of South Africa ( $33^{\circ} 57^{\prime} \mathrm{S}, 18^{\circ} 15^{\prime} \mathrm{E}$ ). The climate is mediterranean, with hot, dry summers and cool, wet winters. Approximately $83 \%$ of the rain falls in a seven month wet season between April and October (Wicht et al., 1969) usually in long duration, low intensity, frontal events. 


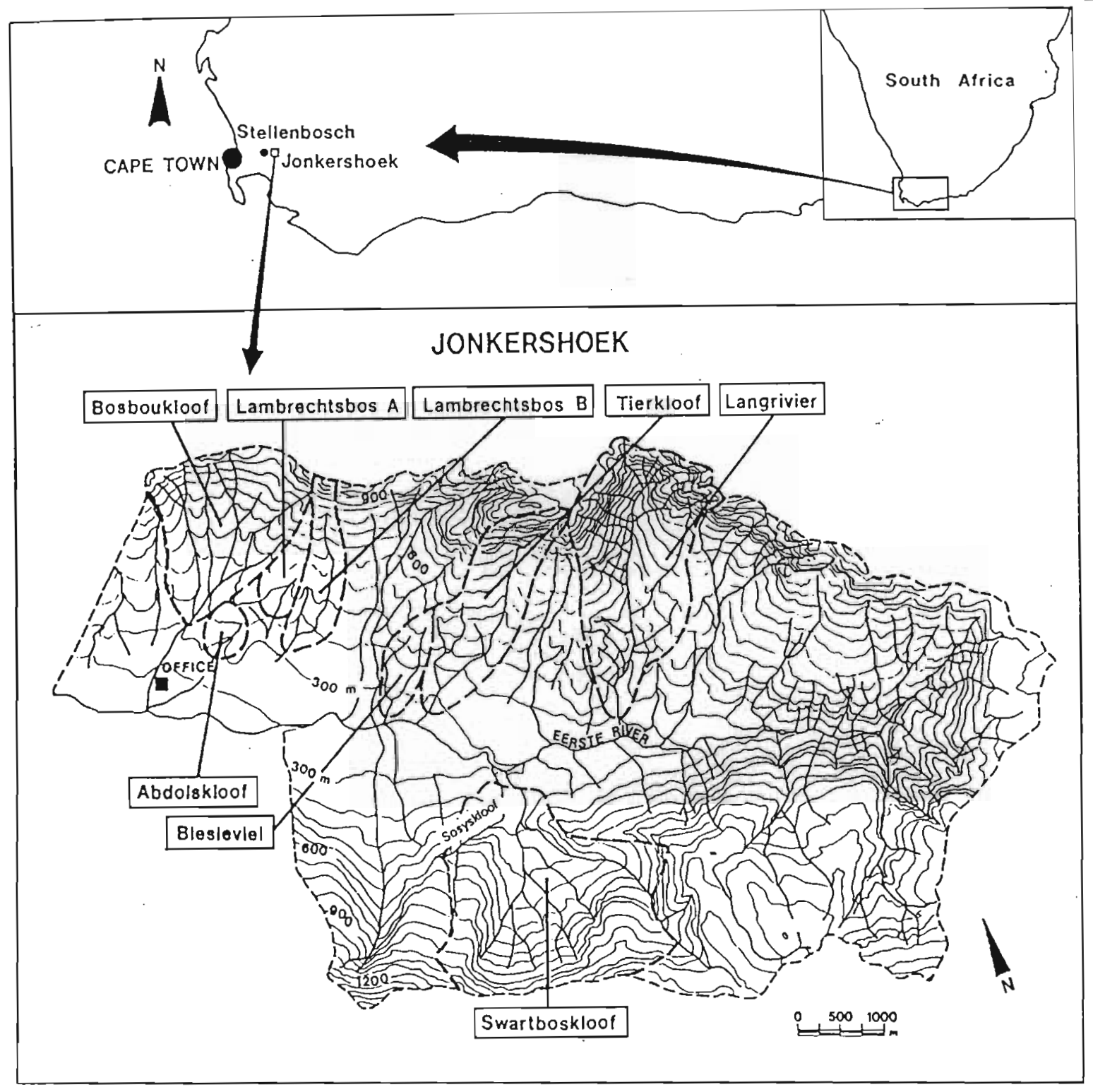

Figure 3.1 The location and topography of the Jonkershoek Valley and its research catchments, showing their boundaries and names.

The indigenous vegetation of the area is fynbos, a sclerophyllous scrub dominated by species of the Proteaceae, Ericaceae and Restionaceae. Along stream courses there are naturally occurring belts of native riparian forest. One of the treatment catchments, Bosboukloof, and both the control catchments, Lambrechtsbos-B and Tierkloof, have been afforested with Pinus radiata which is managed as a saw-timber crop on a 35 - 40 year rotation. Over the periods of comparison used in this study the forest cover in the control catchments has been stable, affording good experimental control. 
Table 3.2 Summary of the vegetation characteristics and treatments of the research catchments.

\begin{tabular}{|c|c|c|c|c|c|}
\hline $\begin{array}{l}\text { Name and } \\
\text { location }\end{array}$ & $\begin{array}{l}\text { Native } \\
\text { vegetation }\end{array}$ & $\begin{array}{c}\% \\
\text { Afforested }\end{array}$ & $\begin{array}{l}\text { Species } \\
\text { Afforested }\end{array}$ & $\begin{array}{c}\text { Age at } \\
\text { time of } \\
\text { fire } \\
\text { (years) }\end{array}$ & Treatment applied \\
\hline $\begin{array}{l}\text { Swartboskloof, } \\
\text { Jonkershoek }\end{array}$ & $\begin{array}{l}\text { tall, } \\
\text { mountain fynbos }\end{array}$ & 0 & - & 29 & $\begin{array}{l}\text { Prescribed burn, dry } \\
\text { season } \\
\text { March } 1987\end{array}$ \\
\hline $\begin{array}{l}\text { Tierkloof, } \\
\text { Jonkershoek }\end{array}$ & $\begin{array}{l}\text { tall, } \\
\text { mountain tynbos }\end{array}$ & 36 & $\begin{array}{l}\text { Pinus } \\
\text { radiata }\end{array}$ & 31 & $\begin{array}{l}\text { Control for Swartboskloof } \\
\text { and Langrivier }\end{array}$ \\
\hline $\begin{array}{l}\text { Langrivier, } \\
\text { Jonkershoek }\end{array}$ & $\begin{array}{l}\text { tall, } \\
\text { mountain fynbos }\end{array}$ & 0 & - & 40 & $\begin{array}{l}\text { Wildfire, wet season } \\
\text { October } 1987\end{array}$ \\
\hline $\begin{array}{l}\text { Bosboukloof, } \\
\text { Jonkershoek }\end{array}$ & $\begin{array}{l}\text { tall, } \\
\text { mountain fynbos }\end{array}$ & 57 & $\begin{array}{l}\text { Pinus } \\
\text { radiata }\end{array}$ & 5 & $\begin{array}{l}\text { Wildfire, dry season } \\
\text { February } 1986\end{array}$ \\
\hline $\begin{array}{l}\text { Lambrechtsbos-B, } \\
\text { Jonkershoek }\end{array}$ & $\begin{array}{l}\text { tall, } \\
\text { mountain fynbos }\end{array}$ & 82 & $\begin{array}{l}\text { Pinus } \\
\text { radiata }\end{array}$ & 22 & Control for Bosboukloof \\
\hline $\begin{array}{l}\text { V1H020, } \\
\text { Ntabamhlope }\end{array}$ & $\begin{array}{l}\text { short, } \\
\text { dense grassland }\end{array}$ & 27 & $\begin{array}{l}\text { Eucalyptus } \\
\text { tastigata }\end{array}$ & 7 & $\begin{array}{l}\text { Wildfire, dry season } \\
\text { August } 1989\end{array}$ \\
\hline $\begin{array}{l}\text { V1H028, } \\
\text { Ntabamhlope }\end{array}$ & $\begin{array}{l}\text { short, } \\
\text { dense grassland }\end{array}$ & 0 & - & - & Control for $\mathrm{V} 1 \mathrm{H} 020$ \\
\hline
\end{tabular}

The research catchments are geologically similar. The Peninsula Sandstone Formation of the Table Mountain Group covers most of the catchments and outcrops as cliffs in the upper elevations. It is highly folded and faulted. Underlying the sandstone and outcropping occasionally, particularly in the lower parts of the valleys, is deeply weathered Cape Granite (Söhnge, 1988). Two aspects of particular hydrological significance are,

(i) the highly decomposed state of the outcropping granite material which allows deep penetration of roots and water, and

(ii) particularly within the more northerly inclined Swartboskloof, the extreme fracturing and faulting of the overlying sandstone which implies that it can convey relatively large amounts of soil-water into the groundwater store. The groundwater moves along these fracture and fault lines, much of it resurfacing along the granite contact at lower altitudes in the main Jonkershoek Valley (Söhnge, 1988).

The soils of the Jonkershoek catchments are derived from hard ortho-quartzitic sandstone (with occasional shale lenses) and coarsely porphyritic granite. Weathering, soil creep and colluviation have resulted in a complex and varied distribution pattern of soil parent materials. The influence of a granite admixture in the soils at lower altitudes is seen in the 
coarse quartz gravel, a higher clay fraction $(6-12 \%$ as opposed to $2-8 \%$ in primarily sandstone derived soils) and, frequently, in a high humus content in the topsoils (Lambrechts et al., 1986). The soils are friable and deep, with the texture class being mainly sandy loams. Their high gravel and rock content, low bulk density and high pore volume result in a high infiltrability and percolation rate (Versfeld, 1981).

\subsubsection{The Jonkershoek Fire Treatments}

\subsubsection{The wildfire in Bosboukloof}

On 18 February 1986, towards the end of a particularly long, dry summer (1.4 mm of rain in the previous month and $54.1 \mathrm{~mm}$ in the previous three months) and under adverse conditions (maximum temperature for the day of $38^{\circ} \mathrm{C}$, minimum relative humidity of $12 \%$ and windspeed at $14: 00$ of $13 \mathrm{~km} \mathrm{~h}^{-1}$ ), a wildfire swept through $80 \%$ of the Bosboukloof catchment. Fuel loads were high because logging slash from some five to eight years previously had been left on site. Most of the slash had been concentrated into windrows, roughly $1.5 \mathrm{~m}$ wide every $10 \mathrm{~m}$, and had been added to by a first pruning of the young second-rotation pine (Pinus radiata) crop. Mean dry fuel loads measured subsequently in adjacent unburnt plantation were $15 \mathrm{~kg} \mathrm{~m}^{-2}$ and $1.1 \mathrm{~kg} \mathrm{~m}^{-2}$ on and between the slash piles respectively. Actual fuel loads varied considerably as felling and re-planting of the catchment had been spread over four years. Many of the old pine stumps from the previous rotation were also consumed in the fire. The result was a fire characterised by a very high absolute amount of energy release and a high rate of energy release.

\subsubsection{The prescribed fire in Swartboskloof}

At the time of the prescribed fire in Swartboskloof the vegetation was 29 years old, which implies that it was "over-mature", with large areas of the dominant shrubs (2 - $4 \mathrm{~m}$ tall) in a state of early senescence. By contrast to the wildfire in Bosboukloof, the fire in Swartboskloof was a carefully planned and executed prescribed burn started on 17 March 1987. Although it was expected to be a hot, late summer burn, soils and fuels had gained considerable moisture from unseasonably high rainfalls in February $(70 \mathrm{~mm})$ and in the week before the fire $(40+\mathrm{mm})$. Soils sampled before the March rainfall had a mean gravimetric wetness in the top $50 \mathrm{~mm}$ of $13.8 \%$. These rains mitigated against a particularly hot fire. 
Fuels were sampled in the immediate vicinity of two sites where overland flow plots were to be established. At each of those two sites, all fuel on eight randomly located plots of either 0.5 or $1 \mathrm{~m}^{2}$ was collected, divided into the fuel classes shown in Table 3.3, and its moisture content and dry mass measured. The larger plots (i.e. $1 \mathrm{~m}^{2}$ ) were used where, visually, fuel loads appeared to be low. The sampling results are given in Table 3.3. There was a large absolute and relative amount of dead and down woody fuel throughout the catchment, but particularly in the lower half of the catchment, which was dominated by tall and over-mature proteoid shrubs.

Table 3.3 Means and standard deviations (s.d.) of oven dry fuel loads $\left(\mathrm{g} \mathrm{m}^{\cdot 2}\right.$ ) in various fuel classes and fuel wetness at the two sites in the Swartboskloof catchment where overland flow plots were installed.

\begin{tabular}{|c|c|c|c|c|c|c|c|c|c|}
\hline & & & & \multicolumn{6}{|c|}{ Fuel class } \\
\hline & & \multirow{2}{*}{\multicolumn{2}{|c|}{ Herbaceous }} & \multicolumn{2}{|c|}{ Living material } & \multicolumn{2}{|c|}{ Dead material } & \multirow{3}{*}{$\begin{array}{l}\text { Total } \\
\text { mass }\end{array}$} & \multirow{3}{*}{$\begin{array}{c}\text { Mean } \\
\text { wetness } \\
\text { (\% of dry } \\
\text { mass) }\end{array}$} \\
\hline & \multirow[b]{2}{*}{ n } & & & \multicolumn{2}{|c|}{ Woody } & \multicolumn{2}{|c|}{ Woody } & & \\
\hline & & & & $\begin{array}{c}\text { diameter } \\
<6 \mathrm{~mm}\end{array}$ & $\begin{array}{c}\text { diameter } \\
>6 \mathrm{~mm}\end{array}$ & $\begin{array}{c}\text { diameter } \\
<6 \mathrm{~mm}\end{array}$ & $\begin{array}{l}\text { diameter } \\
>6 \mathrm{~mm}\end{array}$ & & \\
\hline \multirow[t]{2}{*}{ Site A } & 8 & mean & 24.8 & 102.0 & 90.2 & 808.4 & 496.3 & 1470.6 & 30.6 \\
\hline & & s.d. & 38.1 & 46.3 & 58.2 & 262.1 & 534.2 & 704.4 & 11.5 \\
\hline \multirow[t]{2}{*}{ Site B } & 8 & mean & 88.6 & 188.4 & 400.2 & 1530.6 & 1595.2 & 3777.5 & 28.9 \\
\hline & & s.d. & 89.6 & 201.4 & 652.0 & 438.2 & 1419.0 & 1776.1 & 12.9 \\
\hline
\end{tabular}

The prescribed burn was started at day-break along the upper watershed and allowed to burn slowly downward through the catchment. By mid-afternoon the fire had made little progress, and incendiary devices were dropped from an aircraft into the middle of the catchment to speed up the burn. After nightfall, when conditions were considerably cooler and atmospheric humidity higher, the fire was lit along the access road along the bottom of the catchment, with the result that the lower third of the catchment burned in a higher intensity head-fire. The major patches of riparian forest did not burn. Further detail of the fire is given in Van Wilgen et al. (1992).

\subsubsection{The wildfire in Langrivier}

The Langrivier catchment is a fynbos catchment which serves as a control for experiments to determine the hydrological effects of afforestation in the Jonkershoek Valley. The 
vegetation consists of a mesic mountain fynbos which, owing to the cooler southerly aspect (Figure 3.1), tends to be taller and moister, with larger areas of riverine forest than Swartboskloof. At the time of the fire the vegetation was 45 years old, and contained a large proportion of dead, down woody plant material. On 5 October 1987, fire escaped from a fire-break burning operation, and burned the 245 ha Langrivier catchment in a highintensity fire in a matter of hours. As in Swartboskloof, the moist riparian forest, located in the central part of the catchments did not burn.

Despite the high fuel loads and the fact that it was a wildfire, fuel and soil wetness would have been high because the rainy season had just finished and because of the cool aspect of the catchment. Rainfall in the previous week was $44 \mathrm{~mm}$, in the previous month 180 $\mathrm{mm}$ and in the past three months totalled $673 \mathrm{~mm}$. The riparian forest patches largely escaped burning. Thus it is not likely that soil heating was extreme.

\subsubsection{The Ntabamhlope Catchments}

\subsubsection{Geology and Soils}

The two nested catchments are at the Ntambamhlope Agricultural Research Station in the foothills of the Drakensberg mountain range, near Estcourt in Natal (29. $50^{\prime} \mathrm{S}, 29^{\circ} 50^{\prime} \mathrm{E}$; Figure 3.2) and they form part of the hydrological research network maintained by the Department of Agricultural Engineering of the University of Natal through funding from the Water Research Commission. The catchments are situated on gently sloping terrain (Figure 3.2) in alternating sandstones and mudstones of the Beaufort Group (Karoo Supergroup) of late-Permian to mid-Triassic age. The soils are shallow, highly leached and apedal with a low erodibility (Schmidt and Schulze, 1989). The texture classes are fine silty clay to clay loam, both of which tend to harden when dry. Infiltrability is generally high and permeability is rapid except in the immediate vicinity of the stream where both ratings reduce to moderate because of the clayier soil textures (Schmidt and Schulze, 1989).

\subsubsection{Climate and Hydrology}

The climate at Ntabamhlope is typical of many high altitude summer rainfall areas of South Africa. Summers are wet and hot while winters are dry and sunny with frequent night frosts and mild day temperatures. Around $80 \%$ of the rain falls between October and March, most of this in high intensity convectional rainstorms. Mean annual precipitation and A-pan evaporation at the nearby Ntabamhlope Research Station is $1092 \mathrm{~mm}$ (29 year record) and 


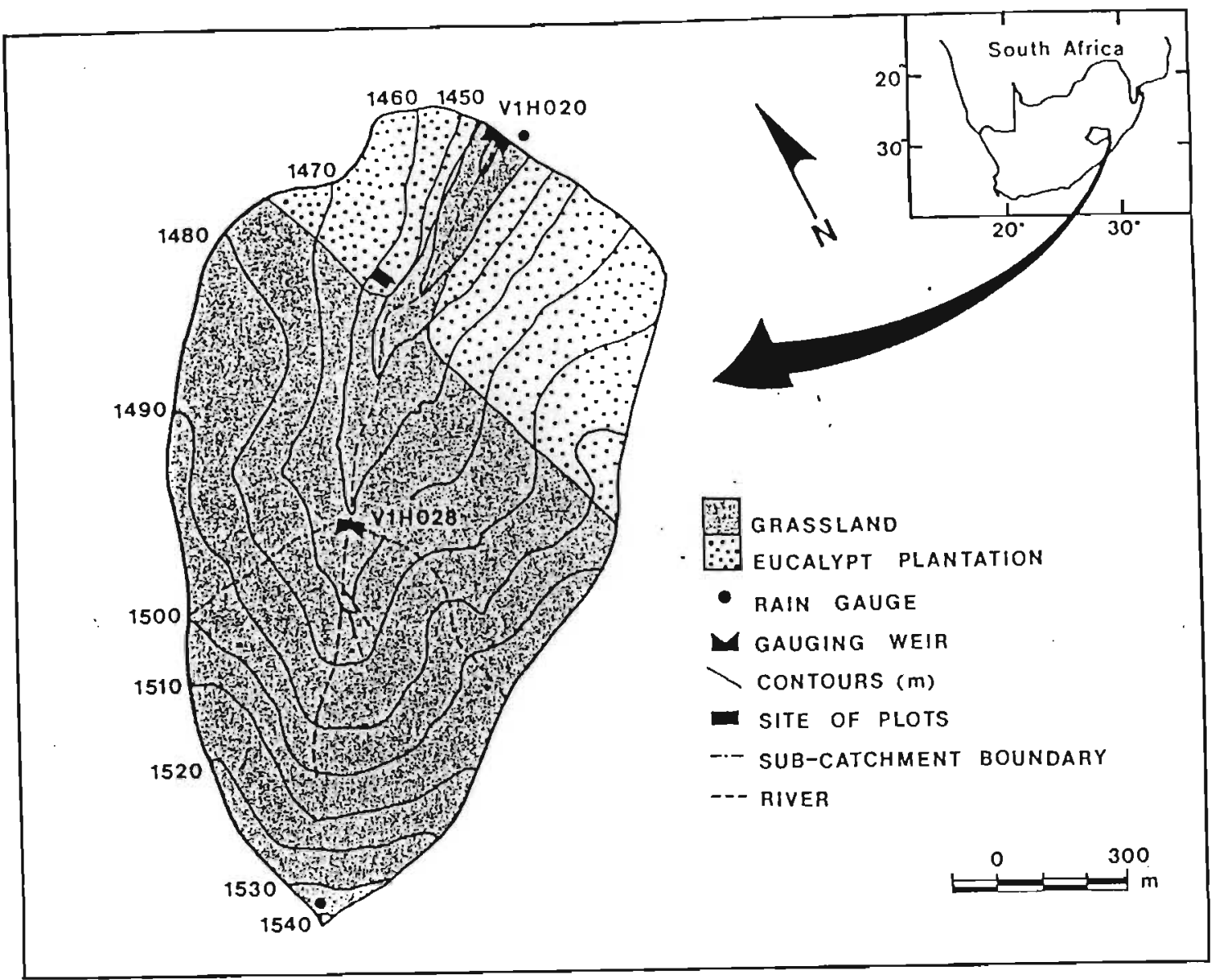

Figure 3.2 Location and topography of the Ntabamhiope catchments, V1H02O and V1H028 catchments.

$.1543 \mathrm{~mm}$ (13 year record), respectively (Schmidt and Schulze, 1989). Over the period 1979 to 1987 the mean annual runoff (MAR) from the upper part of the catchment, used as the control here, was $140 \mathrm{~mm}$ ( $16.7 \%$ of rainfall over the same period) of which $48 \%$ was quick-flow (Schmidt and Schulze, 1989).

\subsubsection{Vegetation}

The native vegetation of the catchments is classified as Highland Sourveld by Acocks (1975). This knee-high grassland is a fire-maintained dominant, usually burned every second year in early spring (September/October). The flanks of the lower catchment were planted to Eucalyptus fastigata (Figure 3.2) in 1976/77 for production of pulp wood on a 10 year cycle. This plantation covers 35 ha in the catchment, a mere $26.5 \%$ of the entire catchment. A broad riparian buffer strip was left unplanted along the channel where slopes steepen towards the stream. This strip is maintained with a healthy grass cover 
burned along with the rest of the grassland catchment. The plantation was felled in $1986 / 87$ and regenerated from coppice.

\subsubsection{The Wildfire at Ntabamhlope}

The fuel load in the eucalypt plantation was high as slash from the felling and thinning operations had been left on site in slash piles roughly $10 \mathrm{~m}$ apart running up and down the slope. Between the slash piles fuel was a lighter and more evenly spread load of leaves, twigs and bark. The lower third of the catchment (roughly the plantation area and the intervening riparian zone, Figure 3.2) was burned in a high-intensity wildfire on 25 August 1989. The wildfire was driven by a warm, dry north-westerly wind and occurred after a prolonged dry (winter) season, at a time when soils and fuels had very low water contents. Maximum air temperature on the day of the fire was $26.5^{\circ} \mathrm{C}$; maximum and minimum relative humidities were $54 \%$ and $20 \%$ respectively. No rainfall had been recorded in the preceding 55 days and total rainfall in the preceding six months had been a mere $44 \mathrm{~mm}$. The result was a hot fire with a high absolute, and high rate of, energy release. All fuels were consumed and the soil surface was left completely exposed beneath dying trees. The soil surface was heated to an ashed condition in those places where fuel loads had been high, and these slash pile sites consequently displayed a higher soil erodibility.

\subsection{METHODS}

\subsubsection{Stream-flow}

\subsubsection{Data Collection}

The catchments used in this study are all established hydrological research catchments, equipped with weirs fitted with compound $90^{\circ} \mathrm{V}$-notch gauges. Stream-flow stage height through the notches was monitored continuously using chart recorders (Belfort in the case of the Jonkershoek catchments, and Ott at Ntabamhlope). Stream-flow charts were digitised and stream-flow volumes summed over weekly periods.

The effects of fire on storm-flow were assessed from an analysis of storm hydrographs which were separated using the standard method of Hewlett and Hibbert (1967; Figure 3.3). The variables

(i) storm-flow volume, i.e. the total volume of runoff over the period of storm-flow), 
(ii) quick-flow volume, i.e. that portion of storm-flow above the fixed-slope separation line of Hewlett and Hibbert (1967),

(iii) peak discharge, i.e. the highest flow rate during the storm,

(iv) initial discharge and

(v) storm-flow duration were measured from each storm hydrograph.

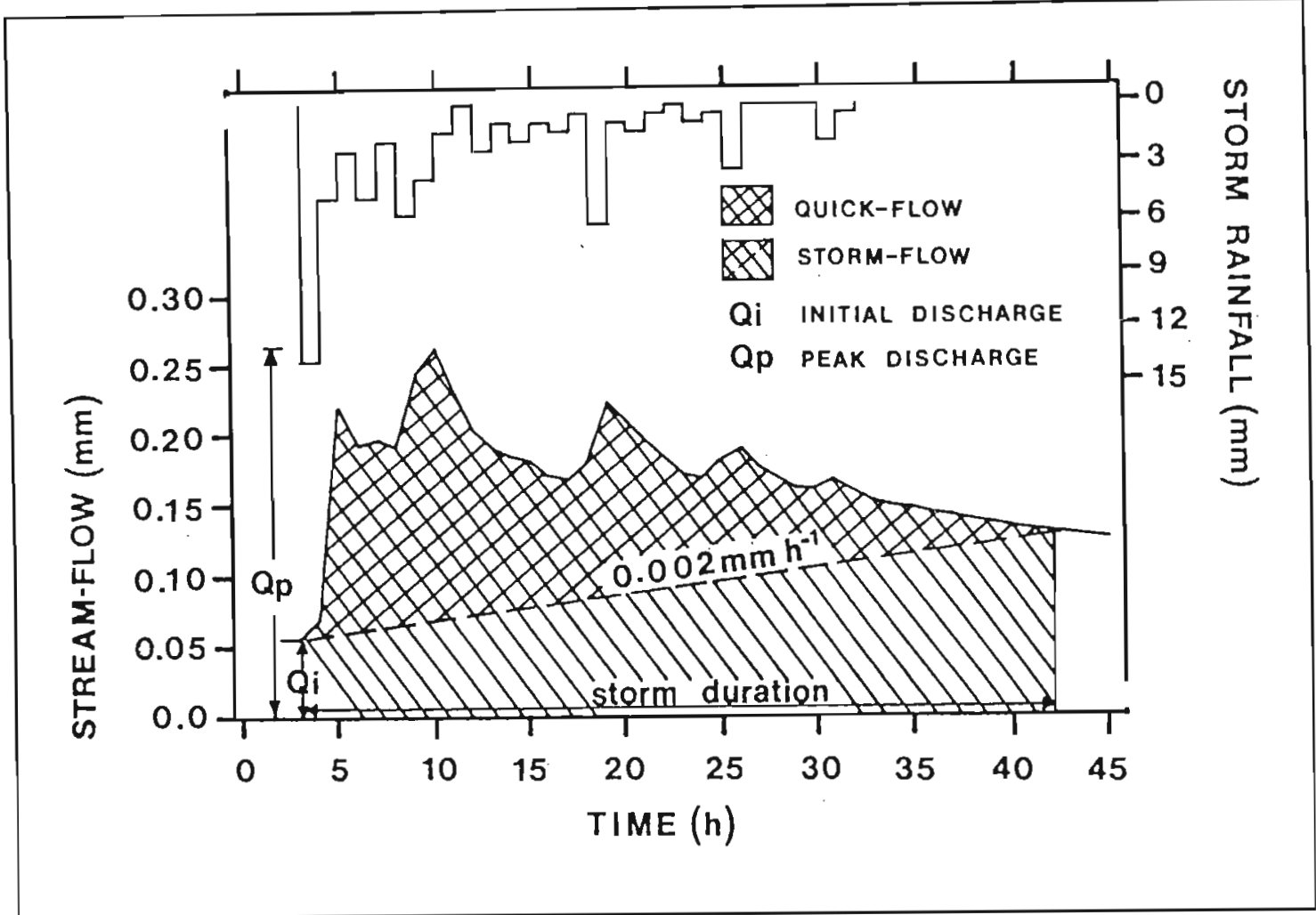

Figure 3.3 The standardised storm hydrograph classification method of Hewlett and Hibbert (1967) applied to an actual storm event (18 July 1988) in the Bosboukloof catchment.

The associated storm rainfall depth, duration and maximum 1-hour and 2-hour rainfall depths were derived from recording Casella rain gauges located in each catchment. The same criteria for the inclusion of storms applied by Hewlett and Bosch (1984) were followed, i.e. at least $20 \mathrm{~mm}$ of rainfall without an interruption of more than six hours. In the case of the Ntabamhlope catchments the minimum storm rainfall was lowered to 15 $\mathrm{mm}$ to increase the sample size. In both Jonkershoek and Ntabamhlope, these cut-off levels excluded few storms which produced distinct hydrographs, i.e. hydrographs which could reasonably be separated. The lower cut-off level in Ntabamhlope was appropriate because of the higher intensity of rain-storms in this part of the country. The calibration period means of the variables generated for the storm-flow analysis are shown in Table 3.4. 
Table 3.4 The mean and standard deviations (s.d.) of the storm-flow variables measured in each research catchment over the pre-fire (calibration) periods.

\begin{tabular}{|c|c|c|c|c|c|c|c|c|c|c|c|}
\hline \multirow[t]{2}{*}{ Catchment } & \multirow[t]{2}{*}{$n$} & & \multirow[t]{2}{*}{$\begin{array}{l}\text { Storm' } \\
\text { rainfall }(P) \\
(\mathrm{mm})\end{array}$} & \multirow[t]{2}{*}{$\begin{array}{c}\text { Storm } \\
\text { duration } \\
\text { (h) }\end{array}$} & \multicolumn{2}{|c|}{$\begin{array}{l}\text { Maximum } \\
\text { rainfall } \\
\text { intensities }\end{array}$} & \multirow[t]{2}{*}{$\begin{array}{c}\text { Initial } \\
\text { discharge } \\
\left(\mathrm{mm} \text { day }^{-1}\right)\end{array}$} & \multirow[t]{2}{*}{$\begin{array}{c}\text { Peak } \\
\text { discharge } \\
(\mathrm{mm} \text { day })\end{array}$} & \multirow[t]{2}{*}{$\begin{array}{l}\text { Storm-flow } \\
(\mathrm{mm})\end{array}$} & \multirow[t]{2}{*}{$\begin{array}{l}\text { Quick-flow } \\
\begin{array}{c}(a) \\
(\mathrm{mm})\end{array}\end{array}$} & \multirow[t]{2}{*}{$\begin{array}{c}\text { Response } \\
\text { ratio (Q/P) } \\
(\%)\end{array}$} \\
\hline & & & & & $\begin{array}{c}\mathrm{mm} \text { in } \\
1 \mathrm{~h}\end{array}$ & $\begin{array}{c}\mathrm{mm} \text { in } \\
2 \mathrm{~h}\end{array}$ & & & & & \\
\hline \multirow{2}{*}{$\begin{array}{l}\text { Swartboskloof } \\
\text { (burned) }\end{array}$} & \multirow[t]{2}{*}{51} & mean & 44.9 & 39.4 & 9.4 & \multirow[t]{2}{*}{ n.m. } & 3.5 & 19.0 & 15.8 & 7.4 & 12.6 \\
\hline & & s.d & 34.4 & 33.3 & 4.0 & & 2.7 & 21.8 & 23.2 & 14.1 & 14.2 \\
\hline \multirow{2}{*}{$\begin{array}{l}\text { Tierkloof } \\
\text { (control) }\end{array}$} & \multirow[t]{2}{*}{50} & mean & 44.7 & 35.2 & 9.1 & \multirow[t]{2}{*}{ n.m. } & 2.2 & 27.5 & 16.4 & 11.5 & 18.6 \\
\hline & & s.d. & 30.7 & 18.8 & 4.2 & & 1.2 & 34.3 & 31.8 & 29.3 & 21.8 \\
\hline \multirow{2}{*}{$\begin{array}{l}\text { Langrivier } \\
\text { (burned) }\end{array}$} & \multirow[t]{2}{*}{65} & mean & 55.4 & 56.6 & 10.3 & 14.7 & 2.3 & 34.7 & 36.6 & 24.5 & 38.6 \\
\hline & & s.d. & 36.8 & 32.9 & 4.0 & 5.3 & 1.6 & 27.1 & 39.7 & 31.6 & 30.2 \\
\hline \multirow{2}{*}{$\begin{array}{l}\text { Bosboukloof } \\
\text { (burned) }\end{array}$} & \multirow[t]{2}{*}{34} & mean & 47.6 & 24.6 & 10.3 & 15.0 & 1.56 & 6.62 & 3.69 & 1.40 & 2.4 \\
\hline & & s.d. & 27.6 & 14.3 & 4.2 & 5.6 & 5.04 & 5.04 & 3.81 & 1.74 & 1.8 \\
\hline \multirow{2}{*}{$\begin{array}{l}\text { Lambrechtsbos-B } \\
\text { (control) }\end{array}$} & \multirow[t]{2}{*}{31} & mean & $40.4^{2}$ & 23.8 & $9.9^{2}$ & $14.7^{2}$ & 0.98 & 4.46 & 3.07 & 1.45 & $1.9^{2}$ \\
\hline & & s.d. & 23.8 & 14.4 & 3.9 & 5.0 & 0.75 & 4.46 & 3.77 & 2.10 & 2.0 \\
\hline \multirow{2}{*}{$\begin{array}{l}\text { V1H020, } \\
\text { Ntabamhlope } \\
\text { (burned) }\end{array}$} & \multirow[t]{2}{*}{31} & mean & 35.5 & 24.4 & $22.7^{3}$ & \multirow[t]{2}{*}{ n.m. } & \multirow[t]{2}{*}{ n.m. } & 43.4 & \multirow[t]{2}{*}{ n.m. } & 4.69 & 3.4 \\
\hline & & s.d & 20.4 & 17.1 & 17.0 & & & 76.4 & & 7.36 & 2.6 \\
\hline \multirow{2}{*}{$\begin{array}{l}\text { V1H028, } \\
\text { Ntabamhlope } \\
\text { (control) }\end{array}$} & \multirow[t]{2}{*}{31} & mean & 34.0 & 29.4 & $22.7^{\circ}$ & \multirow[t]{2}{*}{ n.m. } & \multirow[t]{2}{*}{ n.m. } & 69.3 & \multirow[t]{2}{*}{ n.m. } & 8.11 & 4.8 \\
\hline & & s.d & 24.9 & 25.3 & 17.0 & & & 112.1 & & 14.28 & 2.4 \\
\hline
\end{tabular}

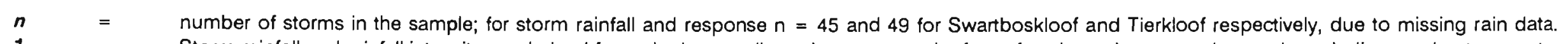

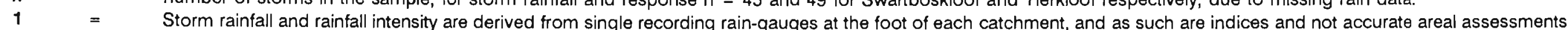
of these variables. Hence response ratio is exaggeratedly high, as $P$ has a low bias.

2 = Rainfall data for 11 larger storms during the earlier period of record were missing owing to instrument malfunction.

$3=$ Maximum 30-minute intensities $\left(\mathrm{mm} \mathrm{h}^{-1}\right)$

n.m. = not measured 
Storm-flow is a function of both rain-storm characteristics and the antecedent soil water status. Soil water status can be approximated using an antecedent precipitation index (API). This was calculated (after Dunne and Leopold, 1978) for the studies at Swartboskloof, Langrivier and Ntabamhlope as follows:

$$
\mathrm{API}_{\mathbf{i}}=\mathrm{API}_{\mathrm{i}-1} \mathrm{~K}+\mathrm{P}
$$

where $\quad \mathrm{API}_{\mathbf{i}}=$ the index for the $i^{\text {th }}$ day (or week)

$A P I_{i-1}=$ the index for the previous day (or week)

$\mathrm{K}=$ an arbitrarily determined decay factor

$\mathrm{P}_{\mathrm{i}-1}=$ the rainfall on the previous day (or week).

Upon analysis of the stream-flow variables it was found that initial discharge gave an equally good measure of general catchment wetness to API. Response ratio for individual storms was derived by dividing quick-flow (expressed as a volume in rainfall equivalents, i.e. $\mathrm{mm}$ ) by storm rainfall.

The separation of hydrographs has been criticised as artificial (Beven, 1987) in that it does not indicate sources of storm water as originally conceived by Horton (1933), i.e. that quick-flow represents the surface and near-surface runoff generated by storm rainfall. Its use here does not imply an assumption that the separated quick-flow represents surface runoff and interflow. Chemical separation of hydrographs has confirmed that relatively little of the storm-flow of humid catchments is "new" water or surface runoff (Pearce et al., 1986). The separation of hydrographs is nonetheless a useful tool for the study of the behaviour of small catchments. Hewlett and Hibbert (1967) proposed a standard slope of the separation line which is independent of catchment area (viz. $1.13 \mathrm{~mm}$ day ${ }^{1}$ day ${ }^{-1}$ ) which allows comparison of storm-flows in different catchments. In the smallish, humid catchments used in this study, this slope, though of itself arbitrary, produced intuitively realistic results, i.e. comparable to graphical methods (e.g. Figure 3.3). This method is consistent, objective and allows comparison of storm-flow response from disparate areas (Hewlett and Hibbert, 1967; Ward, 1975).

\subsubsection{Analysis}

The paired catchment approach was used on the stream-flow data to test for possible effects of fire. This method requires the pre-treatment calibration of the stream-flow in the catchment to be treated against observations from a similar control catchment. The 
calibration relationship is then used as a base-line against which possible treatment effects can be measured.

For individual storm events the multiplicative regression model of the general form

$$
T=\exp ^{\beta_{0}} C^{\beta_{1}} P^{\beta_{2}} I_{60}^{\beta_{3}} I_{120}^{\beta_{4}} Q_{1}^{\beta_{5}} D^{\beta_{6}} \epsilon
$$

was developed for each of the dependent (treatment catchment) storm-flow variables, using the REG and STEPWISE procedures of the SAS statistical package (SAS Institute, 1985)

where $\quad \begin{array}{ll}T \text { and } C & \text { the corresponding treatment and control catchment } \\ \text { variables }\end{array}$
$\begin{array}{ll}\mathrm{P} & \text { storm rainfall }(\mathrm{mm}) \\ \mathrm{I}_{60} \text { and } \mathrm{I}_{120} & =\begin{array}{l}\text { maximum } 1 \mathrm{~h} \text { and } 2 \mathrm{~h} \text { rainfall depths }(\mathrm{mm}) \\ \text { respectively }\end{array} \\ \mathrm{Q}_{i} & \text { initial discharge }\left(\mathrm{mm} \text { day }{ }^{-1}\right) \\ \mathrm{D} & =\text { storm duration }(\mathrm{h}) \\ \epsilon & \text { the model errcr term and } \\ \beta_{0}-\beta_{6} & =\text { fitted regression coefficients }\end{array}$

By taking the logarithm of each variable and introducing a dummy variable, $F$, which assumes the value 0 for the pre-fire condition and 1 for the post-fire condition, the following intrinsically linear, full model which accounts for the fire treatment results:

$$
\begin{gathered}
T^{\prime}=\beta_{0}+\alpha_{0} F^{\prime}+\beta_{1} C^{\prime}+a_{1} F^{\prime}+\beta_{2} P^{\prime}+\alpha_{2} F P^{\prime}+\beta_{3} I_{60}^{\prime}+\alpha_{3} F_{60}+ \\
\beta_{4} I_{120}^{\prime}+a_{4} F_{120}^{\prime}+\beta_{5} Q_{1}^{\prime}+\alpha_{5} F Q_{1}^{\prime}+\beta_{6} D^{\prime}+\alpha_{6} F^{\prime}+\epsilon^{\prime}
\end{gathered}
$$

where the accent (") indicates the logarithm of the variable in each case and $a_{0}-a_{6}$ are the additional fitted regression coefficients for the full model.

The coefficients $\beta_{0}$ and $\beta_{1}-\beta_{6}$ respectively give the intercept and "slope" of the calibration relationship (i.e. pre-fire state) between the catchments, i.e. when $F=0$. The coefficients $a_{0}-a_{6}$ adjust the relationship for a post-fire state, i.e. when $F=1$. The rejection of the null hypothesis $\left(\mathrm{H}_{0}: a_{i}=0\right)$ for any coefficient, $i$, indicates that the fire term explains a significant part of the variation in the dependent storm-flow variable. The test of the null hypothesis, 
$H_{0}: a_{i}=0$, is performed with the t-test for entry of the associated term into the model. This t-statistic can be shown to be the equivalent of an F-test for the extra sum of squares due to entry of an additional term to the model (Kleinbaum and Kupper, 1978).

The weekly stream-flow volume was analysed by the same procedure except that the model contained fewer predictor terms. The independent variables in the best reduced model were chosen from control catchment stream-flow, weekly rainfall and API (as defined in Section 3.2.1.1). The full model had, in addition, the necessary fire dummy variable terms.

In a few cases where a seasonally changing relationship between control and treatment catchments appeared to exist, a dummy variable for season (S) was introduced into the fitting of the regression models. A limited number of these season-specific models provided improved explanation of the variation in the dependent variable, although never to a large extent.

The reduced (i.e. calibration) regression models were used to predict values of each of the dependent variables of interest for the post-fire period. Where a significant effect was found, the difference between these predicted values and the actual measured values (i.e. the deviations from the calibration relationship) were generated to indicate the nature and extent of any response in the dependent variables to the fire.

\subsubsection{Sediment Yields}

As an indication of the amount of soil lost in each catchment following fire, the suspended sediment yields were measured. Base-flow grab samples were taken weekly, upstream of the gauging weir in a turbulent section of the stream where water was well mixed. In Jonkershoek spate flow water samples were taken by automatic rising and falling stage samplers developed by Van Wyk (1983). At Ntabamhlope, samples were taken with an ISCO automatic sampler, set to extract a water sample from the stilling pond at every movement past $50 \mathrm{~mm}$ stage intervals. From the water samples and associated streamflow data, monthly suspended sediment yields were determined. The electrical conductivity (EC) of the water samples collected at Ntabamhlope was also measured. 
Suspended sediment concentrations were determined by vacuum filtering of the water samples through a pre-dried and weighed Whatman glass-fibre filter with a 0.45 micron pore size. Base-flow sediment yield was obtained by multiplying the base-flow for a week by the corresponding grab sample concentration. Storm hydrographs were divided into segments to correspond with the storm-flow samples, and the volume of each multiplied by the associated sediment concentration to give storm-flow sediment yields. Event by event sediment yields were totalled over a month.

In Bosboukloof and Swartboskloof, the wet volume of bedload trapped in the weir stilling ponds was measured and its dry mass estimated by sampling, as described by Van Wyk (1983). At none of the other treatment or control catchments was bedload measured.

\subsubsection{Water Repellent Soils}

It was hypothesised that a major effect of fire on hydrology was through fire-induced water repellency in the soils. The water repellency of soils was determined in the field by the water drop penetration time (WDPT) and critical surface tension (CST) tests as described by DeBano (1981). WDPT is simply the time taken for a drop of water to be absorbed by the soil. The mean time taken (to a maximum of $120 \mathrm{~s}$ ) by 10 drops was used as the WDPT at each sampling point. The CST is the highest surface tension $\left(\mathrm{N} \mathrm{m}^{-1}\right)$, determined using a range of aqueous alcohol solutions of different surface tensions, which readily wets the soil. The values obtained from these tests were combined into a simple water repellency index

$$
\mathrm{RI}=\text { WDPT/CST }
$$

the units of which are meaningless (DeBano, 1981). According to the value of $R I$ the soils were classed as

$$
\begin{aligned}
& \text { repellent }(>1000) \text {, } \\
& \text { somewhat repellent }(1000>\mathrm{Rl}>100) \text { or } \\
& \text { wettable }(<100) \text {. }
\end{aligned}
$$

In Bosboukloof and Swartboskloof twelve and fifteen soil profiles, respectively, in each of the major vegetation types were studied at four depth intervals to assess the influence of the fire on soil wettability. In the Langrivier and Ntabamhlope catchments cursory field surveys were carried out after the fires to determine the extent of water repellency in the soils, these yielding a more qualitative description of repellency at each site. 
It was assumed that the pattern of repellency under the unburnt vegetation was the "norm" and the pattern after fire was compared with this, by using the Chi-squared test, to determine whether fire had changed the situation. In the case of Swartboskloof where the fire was planned, the same sites were visited before and after the fire. For the wildfire sites, nearby unburnt areas were tested to obtain a measure of the wettability of unburnt soils.

\subsubsection{Plot Studies}

The significance of water repellent soils, in terms of the hypothesis being tested, is that they can lead to overland flow during rainstorms. To test this concept, standard overland flow plots ( $3 \mathrm{~m}$ wide $\times 22 \mathrm{~m}$ in length down a slope) were established after the fires to act as large infiltrometers. The plots were enclosed on the sides and top by flat sheet iron, $1 \mathrm{~mm}$ thick, pushed into the soil to a depth of between 50 and $100 \mathrm{~mm}$. At the bottom of the plots different methods were used in each catchment to measure soil loss and/or overland flow.

In both Swartboskloof (six plots) and Langrivier (three plots) the plots were located on steep mid-slope sites where any overland flow was expected to reflect a likely delivery of surface runoff to the stream channel. Results from these plots were compared to those from an unburned control site on a comparable slope situated between the catchments. At each of these 10 plots rainfall, depth of overland flow and total sediment yield were measured. All plots had a slope gradient around 53\%. A multiple regression approach similar to that applied to the catchment analysis, was used on these plot data, using the dummy variable method to test for treatment effects.

In Bosboukloof and Ntabamhlope similar overland flow plots were established, but only the total soil loss was measured. In Bosboukloof the study had not been planned fully and a crude measurement of soil loss was thought to be adequate, while the Ntabamhlope plots could not be visited frequently enough to measure individual storm events. In Bosboukloof, three plots were used to measure soil losses off slopes of 29,35 and $62 \%$. At Ntabamhlope measurements from three adjacent plots on a slope of $30 \%$ were compared with those from a single unburnt plot in a nearby eucalypt plantation. Three plots were thought to be a minimum number to give a rough estimate of soil loss. Two of the three burned plots were on the lines of slash piles while the third was on the interrow between them. 
In this chapter the research catchments and the common measurement and analysis methods used in them have been described. The next four chapters present and discuss the results of the studies in each of the four burned catchments in turn. 
CHAPTER 4

\section{THE BOSBOUKLOOF STUDY}

This chapter documents the results of the studies in the partially (57\%) afforested Bosboukloof catchment which burned in a wildfire in February 1986. The catchment and study methods have been described in the previous chapter. Hence only the details of catchment-specific study methods are given here, along with a presentation and discussion of the results. The chapter concludes with a synopsis which attempts to draw together the findings of the studies at the various scales.

\subsection{STUDIES OF SOIL WETTABILITY}

\subsubsection{Design and Analysis of the Soil Wettability Study}

The Bosboukloof field study of soil wettability was designed as a randomized block experiment. Three vegetation types were designated as three blocks, namely

(i) pine plantation,

(ii) eucalypt plantation (which occurred as two narrow belts, one within the catchment and the other adjacent to it) and

(iii) fynbos (which occurs between and around the pine compartments).

The eucalypt belts were sampled although they only covered a limited area in the catchment $(<0.5 \%)$, as it was suspected that these soils were particularly resistant to wetting. The three treatments were

(i) no fire,

(ii) low fuel-load burn and

(iii) high fuel-load burn.

Water repellency tests were done at four depths in the soil profile $(0-10,10-30,30-100$ and $>100 \mathrm{~mm}$ ). The soil profile was cut to form four flattish steps at the above depth intervals, and the tests were performed up to 10 times on each step. A single score, that which best 
attempt to account for the typically high spatial variability of soil wettability, though in hindsight repeated sampling at each depth at each profile would have been more acceptable from a statistical point of view. Twelve sample points were selected in each experimental unit giving $3 \times 3 \times 4 \times 12$ soil wettability determinations.

The two tests used were water drop penetration time (WDPT) and critical surface tension (CST) which were combined to give a repellency index, RI (DeBano, 1981; see also Sections 3.2.3 and 9.1.2 for detail).

The results of the water repellency tests were evaluated with an analysis of variance (ANOVA) for a split plot design (GENSTAT, 1987). This allowed for testing of differences due to depth, vegetation type, fire and their interactions, using the WDPT and CST measures of repellency for separate analyses. Soils tended to score towards the extremes of the scale of repellency - wettability, producing a bimodal distribution of the WDPT and CST values. As a result the ANOVA produced a skewed residual plot. For these reasons it was decided that a non-parametric test of repellency was more appropriate. Therefore, the frequency of the three RI classes at each depth were compared between vegetation types and treatments using the Chi-squared test for comparison of frequency distributions (Steel and Torrie, 1960).

\subsubsection{Results of the Soil Wettability Study}

The results of the water repellency tests are shown schematically in Figure 4.1, from which the pattern of occurrence of repellent soils can be seen. Both the vegetation type and the treatments had significant effects.

Soils under unburnt fynbos vegetation were largely wettable; repellency was weak and occurred only on the soil surface. Fire in the fynbos generated some repellency at shallow depths below the surface, while destroying any repellent effects in the surface soils (Figure 4.1).

In the unburnt pine plantation repellent soils were not frequent but occurred at all depths. Field observations showed that they were associated with deep litter accumulations and obvious (white) fungal mycelia development in the needle litter. The fire destroyed any repellency there may have been in surface soil layers. Strongly repellent soils were 


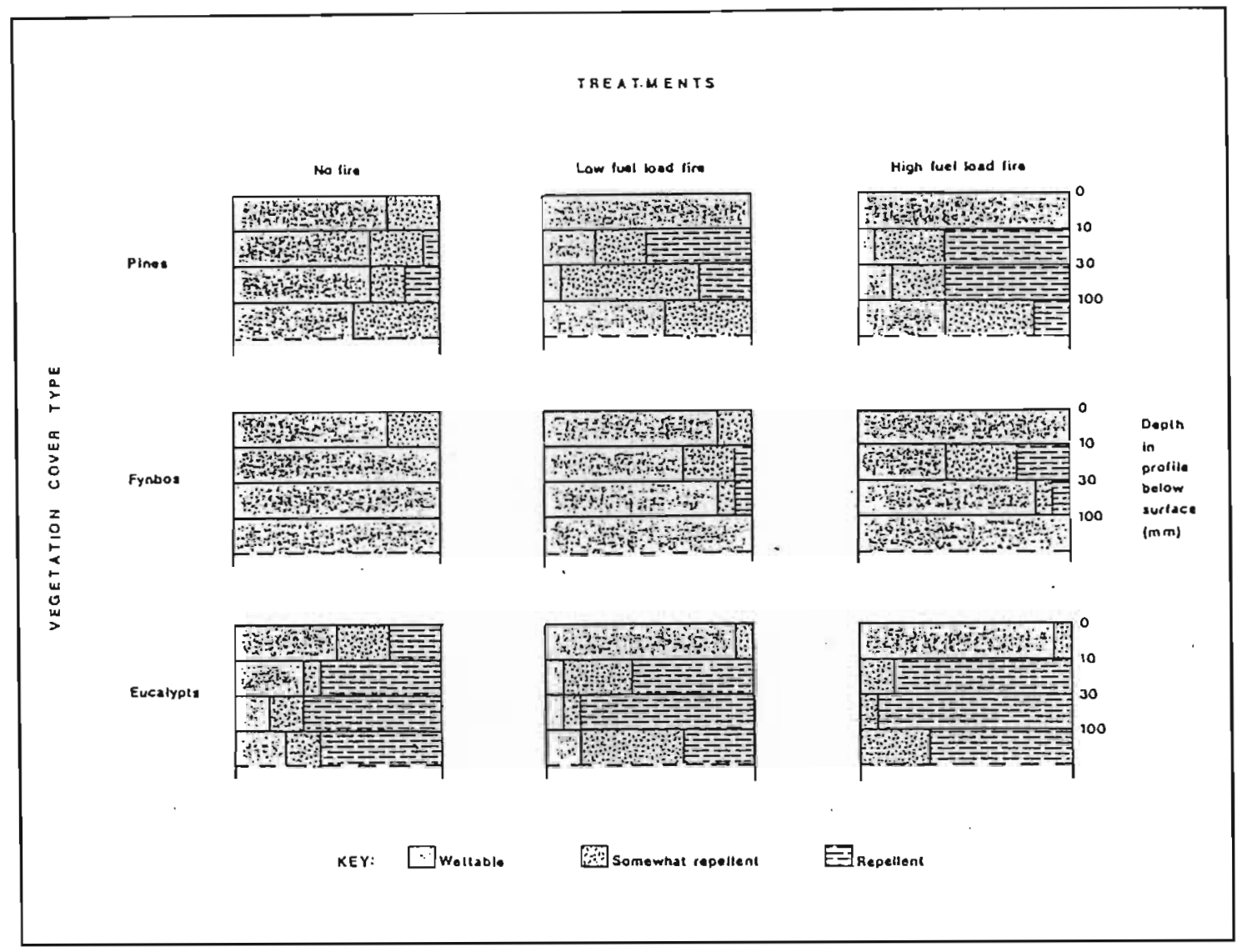

Figure 4.1 A schematic representation of the soil wettability sampling results from Bosboukloof showing the proportion of 12 samples at each depth in each repellency class.

developed below the surface to depths of up to $150 \mathrm{~mm}$. Greater repellencies, to a greater depth in the soil profile, were found under the high fuel load conditions. The repellent layer was seldom continuous over a large area; it being broken frequently by deeply burned patches, burnt-out root channels and rocks.

Soils beneath the small area of eucalypt trees in the Bosboukloof catchment were the most repellent of all the soils, in both the burned and unburned condition (Figure 4.1). Without the influence of fire the soils were highly repellent at all depths down to 100 to $150 \mathrm{~mm}$. The effect of fire was to burn off some repellency on the surface, but overall there was an increase in the frequency of repellency in the sub-surface layers. 


\subsection{STUDIES AT THE PLOT SCALE}

\subsubsection{Soil Erosion from Small Plots}

Overland flow plots were installed on mid-slope sites in Bosboukloof only after it was suspected that there had been a fire effect. Two plots were completed in May 1986, well after the start of the winter rainfall season, and the third plot was completed in June. Soil losses measured on the three overland flow plots are shown in Figure 4.2. Soil loss increased with increasing slope angle (29 - 62\%), ranging from 9.9 to 25.9 t ha $^{-1}$ over the six to seven months of measurement (Scott and Van Wyk, 1990). This underestimates actual soil losses on these sites, as the early part of the wet season (April and May) following the fire was not sampled.

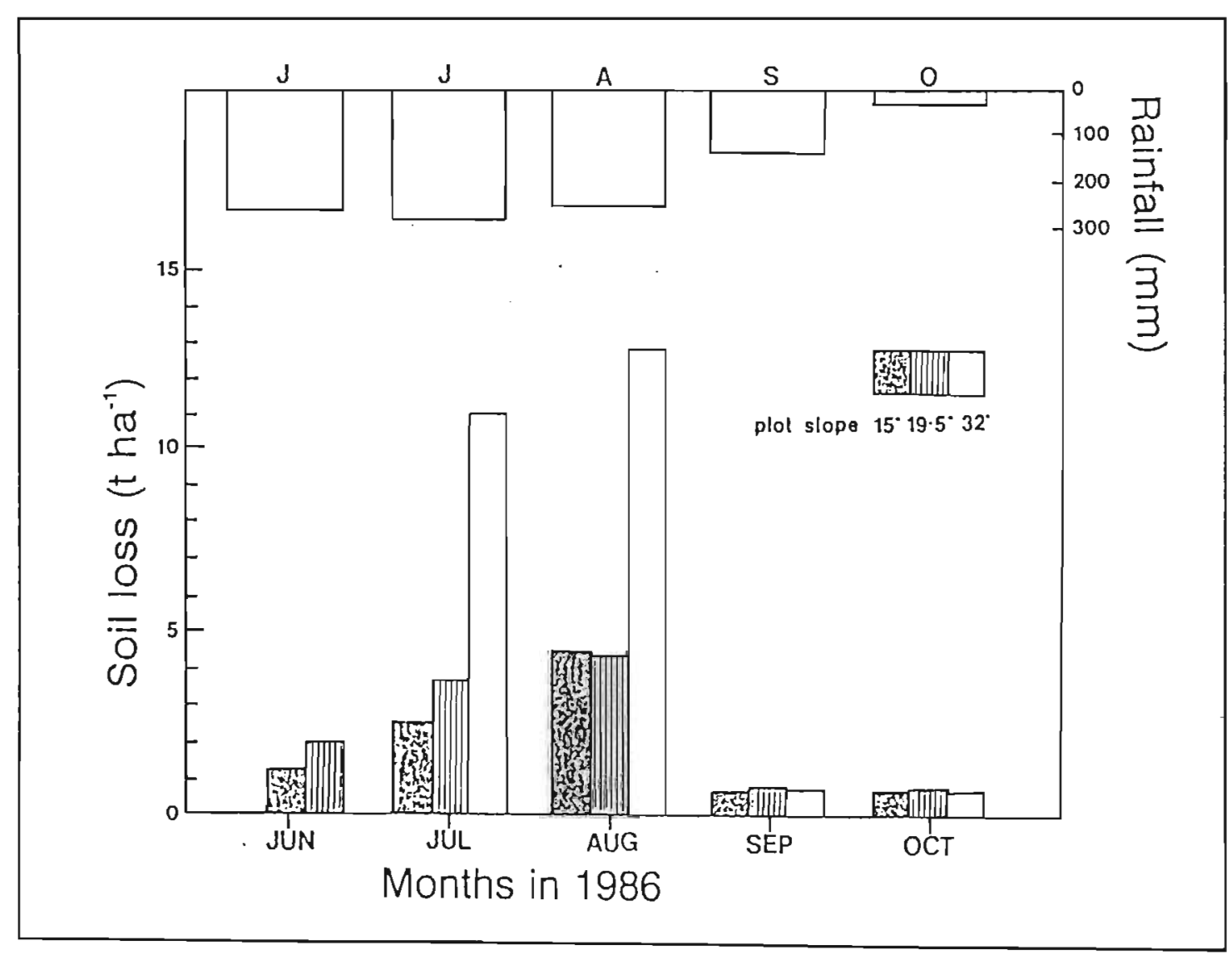

Figure 4.2 The soil losses measured on three overland flow plots on slopes of 27, 35 and $62 \%$ in the Bosboukloof catchment. 


\subsection{STUDIES AT THE CATCHMENT SCALE}

\subsubsection{Stream-flow}

The Bosboukloof catchment burned in February 1986. The stream-flow variables measured over the three hydrological years (April - March) 1983 to 1985 were used to develop calibration relationships against which the variables measured in the first two years after the fire (1986 and 1987) were compared. The fire caused a marked increase in stream-flow and, particularly, in the various storm-flow components (Tables 4.1 and 4.2, Figures $4.3 \mathrm{~b}$, $d$ and $f$. The mean pre-treatment values of the variables used in the stream-flow analysis are shown in Table 3.4. These show the low storm response of the Bosboukloof catchment, with quick-flow representing only $2.3 \%$ of storm rainfall in the three-year calibration period.

Table 4.1 Significant $(\alpha<0.05)$ predictor terms in the multiple regression models developed for the pre-fire and full periods of storm-flow data in the Bosboukloof catchment. The presence of the fire dummy variable $(F)$ in the full period models indicates a significant effect of fire.

\begin{tabular}{lllllll}
\hline \multirow{2}{*}{$\begin{array}{l}\text { Dependent } \\
\text { variable }\end{array}$} & \multicolumn{2}{l}{ Calibration period } & \multicolumn{5}{l}{ Full measurement period } \\
\cline { 2 - 8 } & $\begin{array}{l}\text { Significant } \\
\text { predictor } \\
\text { terms }\end{array}$ & $\begin{array}{l}\text { Error } \\
\text { d.f. }\end{array}$ & Adjusted $\mathrm{A}^{2}$ & $\begin{array}{l}\text { Significant } \\
\text { predictor terms }\end{array}$ & $\begin{array}{l}\text { Error } \\
\text { d.f. }\end{array}$ & Adjusted $\mathbf{R}^{2}$ \\
\hline Weekly stream-flow & $\mathrm{C}, \mathrm{R}, \mathrm{S}$ & 94 & 0.89 & $\mathrm{C}, \mathrm{S}, \mathrm{F}$ & 198 & 0.97 \\
Storm-flow volume & $\mathrm{C}, \mathrm{Q}, \mathrm{D}$ & 28 & 0.98 & $\mathrm{C}, \mathrm{I}_{80}, \mathrm{Q}_{11}, \mathrm{D}, \mathrm{F}$ & 62 & 0.98 \\
Quick-fiow volume & $\mathrm{C}, \mathrm{P}$ & 30 & 0.96 & $\mathrm{C}, \mathrm{I}_{80}, \mathrm{P}, \mathrm{D}, \mathrm{F}$ & 62 & 0.98 \\
Peak discharge & $\mathrm{C}, \mathrm{I}_{120}$ & 30 & 0.96 & $\mathrm{C}, \mathrm{I}_{80}, \mathrm{I}_{120}, \mathrm{~F}$ & 63 & 0.97 \\
Response ratio & $\mathrm{Pd}, \mathrm{I}_{80}$ & 31 & 0.94 & $\mathrm{Pd}, \mathrm{I}_{80} \mathrm{I}_{120}, \mathrm{D}, \mathrm{F}$ & 62 & 0.94 \\
\hline
\end{tabular}

$\begin{array}{lll}\text { Key: } \quad \text { R } & \text { weekly rainfall }(\mathrm{mm}) \\ \mathrm{C} & = & \text { the corresponding control catchment variable } \\ \mathrm{F}, \mathrm{S} & = & \text { dummy variables for fire and season, respectively } \\ \mathrm{D} & = & \text { storm duration }(\mathrm{h}) \\ \mathrm{P} & = & \text { storm precipitation }(\mathrm{mm}) \\ \mathrm{I}_{80,120} & = & \text { maximum rainfall }(\mathrm{mm}) \text { over } 1 \mathrm{~h} \text { and } 2 \mathrm{~h} \text { periods } \\ \mathrm{Q}_{1} & = & \text { initial discharge }(\mathrm{mm} \text { day') or antecedent precipitation index }(\mathrm{mm}) \\ \mathrm{Pd} & = & \text { peak discharge }(\mathrm{mm} \text { day') in control catchment; used to predict response ratio } \\ & & \text { because of missing rainfall data in the control catchment }\end{array}$

The results of the regression analyses for fire effects are shown in Table 4.1 The fire caused a significant increase in all the stream-flow variables, as indicated by the presence 
of a fire dummy variable in each full model. The effect of the fire on the storm-flow components is clearly visible in the time trend plots of deviations in the burned catchment's actual quick-flow volume, peak discharge and response ratio about the calibration regression curves (Figure 4.3b, $d$ and $f$, respectively). The pattern of deviations in stormflow volume was much the same as for quick-flow volume. It can be seen that deviations are greatest during the winter season when stream-flows and storm-flows are highest.

The observed means of the stream-flow variables and the estimated increases following fire are given in Table 4.2. Storm-flow volume increased by means of $2.4 \mathrm{~mm} \mathrm{(62 \% )} \mathrm{and}$ $0.9 \mathrm{~mm}(20 \%)$ in the first and second post-fire years, respectively. These increases were composed mainly of observed mean quick-flow volume increases of $2.2 \mathrm{~mm}(201 \%)$ and $0.8 \mathrm{~mm}(47 \%)$ in the first and second post-fire years, respectively. Peak discharge increased by means of 17.3 (290\%) and $6.8 \mathrm{~mm}^{-1}$ day $^{-1}(108 \%)$. Response ratio increased from a pre-fire mean of $2.3 \%$ to means of $7.5 \%$ ( $242 \%$ increase) and $4.1 \%$ ( $88 \%$ increase) over the two years. Annual stream-flow volume (total flow) showed small but significant $(\alpha<0.01)$ increases of $70(12 \%)$ and $61 \mathrm{~mm}(11 \%)$ in the first and second years respectively.

The first year increase in total flow was composed largely (57\%) of increased quick-flow. This implies that only $30 \mathrm{~mm}$ in the year could be attributed to an increase in base-flows, and hence the overall wetness of the catchment. In the second year quick-flows composed only $25 \%$ of the total flow increase. This indicates the rapid return toward prefire stream-flow generation in the burned catchment, which is also clear in the plot of stream-flow deviations about the calibration regression (Figure 4.4). 

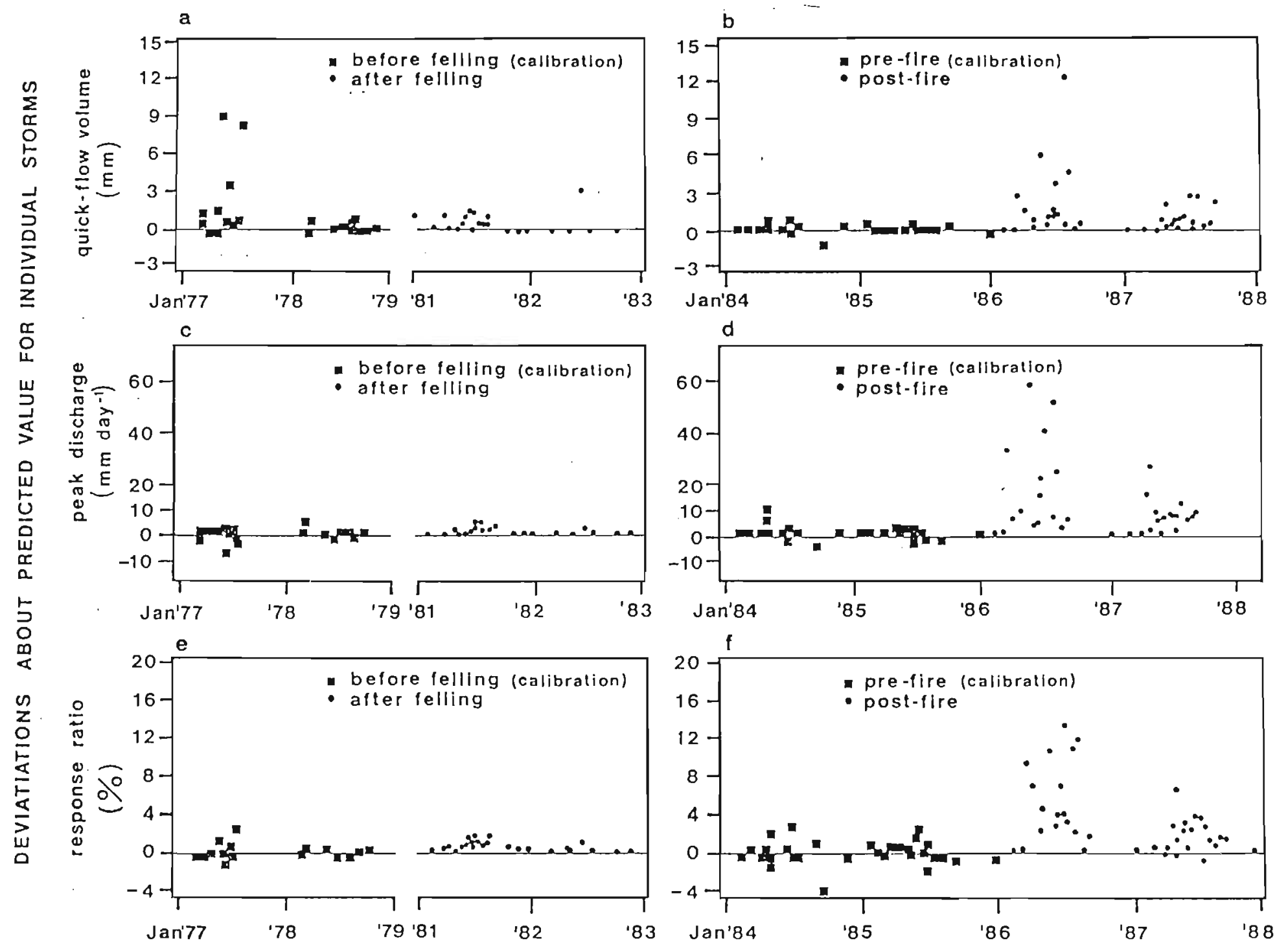

Figure 4.3 Time plots of the differences between the observed and expected values of quick-flow volume (a \& b), peak discharge (c \& d) and response ratio (e \& f in Bosboukloof over the calibration and treatment perlods for both clear-felling and wildfire. 


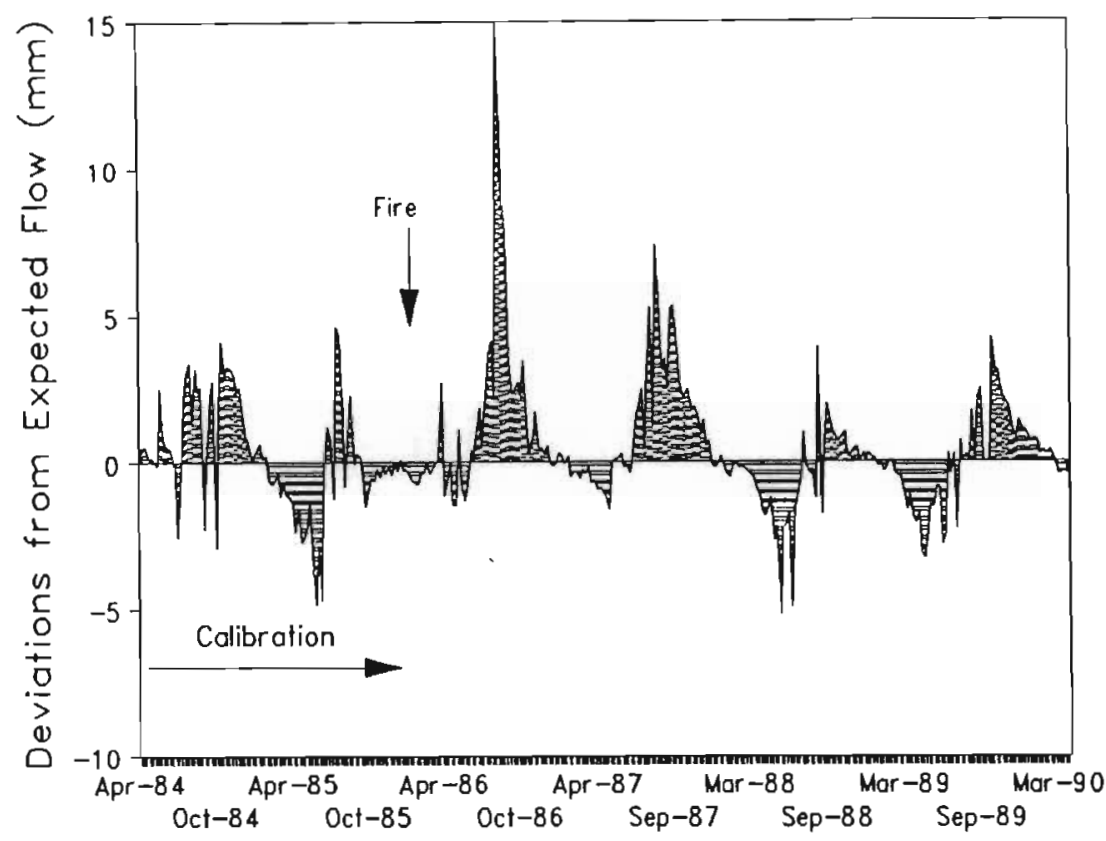

Figure 4.4 The deviations in weekly stream-flow volumes about the calibration regression relationship in Bosboukloof, indicating the declining yleld increase in the four hydrological years following fire.

Table 4.2 Increases in stream-flow variables as a result of the fire in the Bosboukloof catchment.

\begin{tabular}{|c|c|c|c|c|c|c|c|c|}
\hline \multirow[t]{2}{*}{$\begin{array}{l}\text { Stream-flow } \\
\text { variables }\end{array}$} & \multicolumn{2}{|c|}{$\begin{array}{l}\text { Recorded pre- } \\
\text { fire }\end{array}$} & \multicolumn{2}{|c|}{$\begin{array}{l}\text { Recorded in } \\
\text { first post-fire } \\
\text { year }\end{array}$} & \multirow[t]{2}{*}{$\begin{array}{c}\text { Change over } \\
\text { expected } \\
\text { value } \uparrow\end{array}$} & \multicolumn{2}{|c|}{$\begin{array}{c}\text { Recorded } \\
\text { in second } \\
\text { post-fire } \\
\text { year }\end{array}$} & \multirow[t]{2}{*}{$\begin{array}{l}\text { Change } \\
\text { over } \\
\text { expected } \\
\text { value }\end{array}$} \\
\hline & mean & $\mathbf{n}$ & mean & $\mathbf{n}$ & & mean & $n$ & \\
\hline $\begin{array}{l}\text { Weekly stream-flow } \\
\text { (mm) }\end{array}$ & 9.9 & 112 & 14.1 & 44 & $12 \%$ increase & 11.4 & 53 & $\begin{array}{l}11 \% \\
\text { increase }\end{array}$ \\
\hline Storm-flow (mm) & 3.4 & 36 & 6.4 & 18 & $62 \%$ increase & 5.1 & 19 & $\begin{array}{l}20 \% \\
\text { increase }\end{array}$ \\
\hline $\begin{array}{l}\text { Quick-flow volume } \\
\text { (mm) }\end{array}$ & 1.4 & 34 & 3.6 & 18 & $201 \%$ increase & 2.2 & 19 & $\begin{array}{l}47 \% \\
\text { increase }\end{array}$ \\
\hline $\begin{array}{l}\text { Peak discharge } \\
\left(\mathrm{mm} \text { day') }\left\{\mathrm{m}^{3} \mathrm{~s}^{-1}\right\}\right.\end{array}$ & $\begin{array}{l}6.6 \\
\{0.2\}\end{array}$ & 34 & $\begin{array}{l}22.5 \\
\{0.75\}\end{array}$ & 18 & $290 \%$ increase & $\begin{array}{l}12.0 \\
\{0.40\}\end{array}$ & 19 & $\begin{array}{l}108 \% \\
\text { increase }\end{array}$ \\
\hline Response ratio (\%) & 2.3 & 23 & 7.5 & 18 & $242 \%$ increase & 4.1 & 19 & $\begin{array}{l}88 \% \\
\text { increase }\end{array}$ \\
\hline
\end{tabular}




\subsubsection{Sediment Yields}

Suspended sediment was sampled at the weirs of the treatment and control (Lambrechtsbos-B) catchments both by weekly grab sampling and by automatic rising and falling stage samplers developed by Van Wyk (1983). From these samples and associated stream-flow data, monthly suspended sediment yields were determined for the 13 full months prior to, and the 10 months immediately after the Bosboukloof fire.

For comparison of suspended sediment yields the monthly yield from the treatment catchment was expressed as a proportion of the yield from the control catchment. The post-fire increases in suspended sediment yield from Bosboukloof were tested for significance by the non-parametric Wilcoxon-Mann-Whitney test (Steel and Torrie, 1960). A non-parametric test was considered appropriate because of the small sample size and the non-independence of sequential samples.

Monthly suspended sediment yields from Bosboukloof and Lambrechtsbos-B for 1985 and 1986 are plotted in Figure 4.5. The increased sediment loss after the fire in Bosboukloof is apparent when compared to the pre-fire and control catchment yields. The mean suspended sediment yield from Bosboukloof for the period March to December increased, as a result of the fire, from $1.6 \mathrm{t} \mathrm{ha}^{-1}$ in 1985 to $6 \mathrm{t} \mathrm{ha}^{-1}$ in 1986 (Scott and Van Wyk, 1990). The bedload loss from Bosboukloof in 1985 was estimated at $0.45 \mathrm{t} \mathrm{ha}^{-1}$ while that for 1986 was $1.83 \mathrm{tha} \cdot{ }^{1}$. Thus both suspended and bedload yields increased roughly four-fold (Scott and Van Wyk, 1990).

The results of the non-parametric Wilcoxon-Mann-Whitney tests on the sediment yield data are given in Table 4.3. The post-fire increases in monthly suspended sediment yields from Bosboukloof were highly significant $(\alpha<0.01)$, while there was no significant change ( $\alpha$ $>0.05$ ) in sediment yields from the control catchment over the same period (Scott and Van Wyk, 1990). 


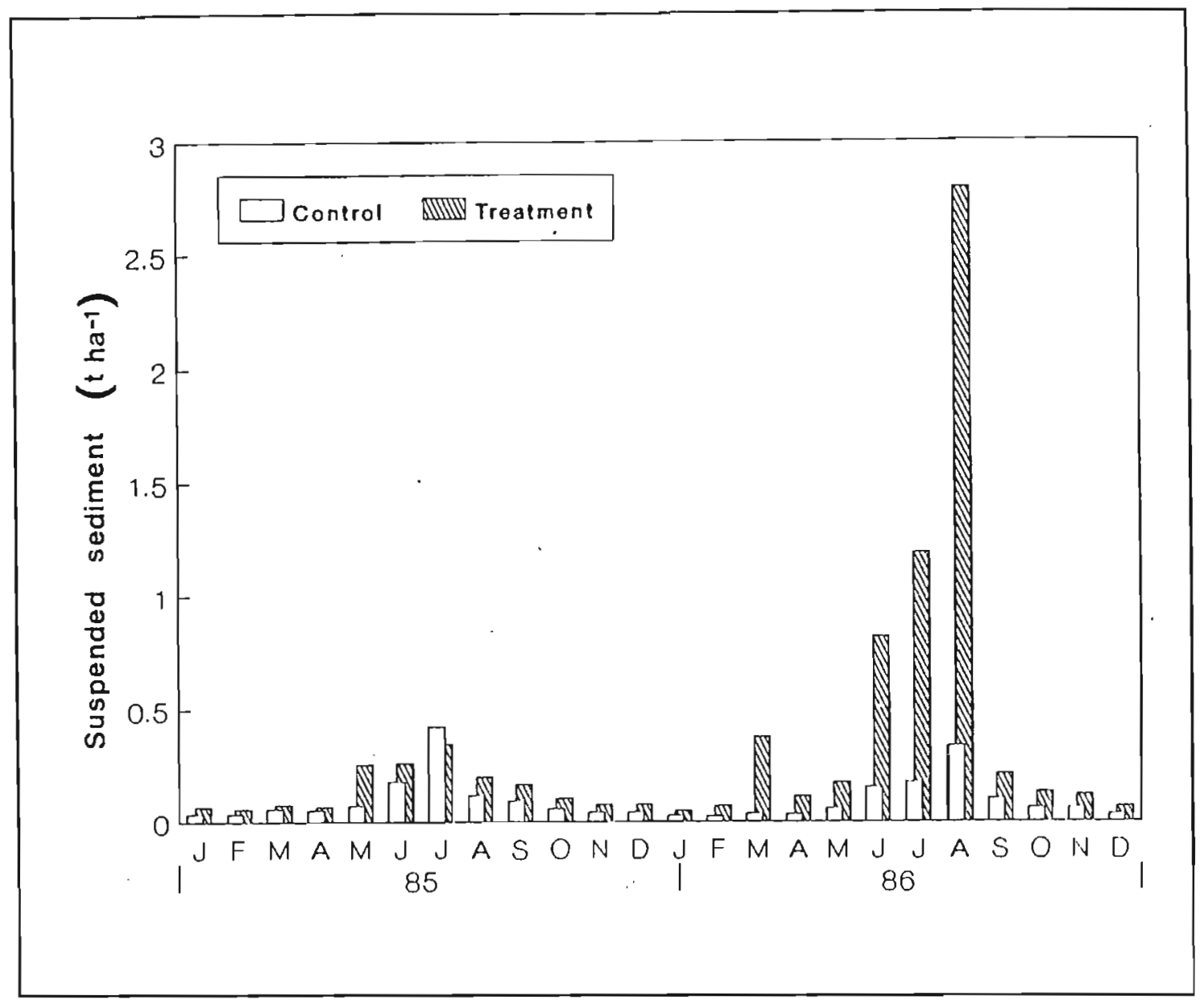

Figure 4.5 Monthly suspended sediment yields in Bosboukloof and its control catchment, Lambrechtsbos-B, before and after the fire in Bosboukloof in February 1986.

Table 4.3 Results of the non-parametric Wilcoxon-Mann-Whitney tests on the monthly suspended sediment yield data from the burned Bosboukloof and the control catchment, Lambrechtsbos-B.

\begin{tabular}{|c|c|c|c|c|c|}
\hline & $\begin{array}{l}\text { Pre-fire } \\
\text { period: Jan. } \\
85 \text { - Jan. } 86\end{array}$ & $\begin{array}{l}\text { Post-fire } \\
\text { period: Mar. } \\
86 \text { - Dec. } 86\end{array}$ & $\begin{array}{l}\text { Value of } Z \\
\text { approximation }\end{array}$ & \multicolumn{2}{|c|}{$\begin{array}{l}\text { Significance } \\
\text { level for } \\
\text { rejection of } H_{0} \text { : } \\
\text { no change }\end{array}$} \\
\hline Sample size & 13 & 10 & & & \\
\hline $\begin{array}{l}\text { Expected rank sums under } \\
H_{\sigma}: \text { no change }\end{array}$ & 156 & 126 & & & \\
\hline Actual rank sums - Bosboukloof & 122 & 154 & 2.08 & 0.02 & * \\
\hline $\begin{array}{l}\text { Actual rank sums - } \\
\text { Lambrechtsbos-B }\end{array}$ & 150 & 126 & 0.34 & 0.367 & NS \\
\hline $\begin{array}{l}\text { Actual rank sums for the ratio } \\
\text { (Bosboukloof/Lambrechtsbos-B) }\end{array}$ & 97 & 179 & 3.63 & 0.0001 & 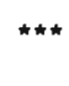 \\
\hline
\end{tabular}

NS = not significant; ${ }^{\star}=\mathrm{P}<0.05 ;^{\star \star \star}=\mathrm{P}<0.01$ 


\subsection{THE EFFECTS OF CLEAR-FELLING ON STREAM-FLOW}

To establish that there was a specifically fire-related effect in the response of the Bosboukloof catchment to burning, it was necessary to show that the observed response was different from that which resulted from simply clearing the standing biomass in the catchment. The pine plantation in the Bosboukloof catchment had been clear-felled a few years before the fire. The opportunity therefore existed to compare the hydrological effects of fire and clear-felling in the same catchment.

\subsubsection{Data Collection and Analysis}

Clear-felling of the pine plantation in Bosboukloof was spread over four years, commencing in 1979 and completed in 1982. This meant that, unlike the fire which could be conceived as a virtually instantaneous treatment, there was a long period when Bosboukloof was neither cleared nor fully planted. For this reason some storm-flow data had to be omitted from the analysis during the treatment period. The pre-treatment period was taken as the hydrological years (April to March) of 1977 and 1978, and post-treatment as the period after $70 \%$ of plantation was cleared (in effect the hydrological years of 1981 and 1982). For the analysis of total flow the continuous flow record was used, so as to determine at what stage clearing began to have an effect. Cleared compartments were replanted, on average, within a year. Over the short period of comparison in this study the second rotation crop was not expected to influence stream-flow noticeably, as Van Wyk (1987) had detected stream-flow reductions only seven years after the initial planting of this same catchment. The Lambrechtsbos-B catchment was again used as a control for Bosboukloof. At the commencement of clear-felling in Bosboukloof the Pinus radiata plantation in Lambrechtsbos-B was 15 years old by which age its water use characteristics, according to the findings of Van Wyk (1987), can be expected to have been relatively stable.

The same storm-flow variables were generated by hydrograph separation as for the study of the effects of fire (ct. Chapter 3.2.1.1 and Figure 3.4). The weekly stream-flow volumes were also analysed. The test for the clear-felling effect was the same as used to test for effects of fire (Chapter 3.2.1.2), namely the dummy variable method of multiple regression analysis. 


\subsubsection{Hydrological Effects of Clear-felling}

Clear-felling caused significant increases in all the measured storm-flow variables: stormflow and quick-flow volumes, peak discharge and response ratio (Tables 4.4 and 4.5; Figure 4.3). In the two hydrological years (1981 and 1982) storm-flow volumes increased by a mean of $0.45 \mathrm{~mm}$ per storm (23\%) which was composed largely of quick-flow volume increases of $0.30 \mathrm{~mm}(53 \%)$; while peak discharge and response ratio increased by means of 46 and $60 \%$ respectively.

Actual means of the storm-flow variables shown in Table 4.5 declined in the two postclearing years, which were drier. But relative to the expected values after felling (based on the calibration relationships) there were clear, significant increases in all the variables measured. By the wet season of 1982 all the timber plantations had been cleared but some re-planted timber stands were well established by this time, and the increase in storm-flow variables is consequently smaller in this second year (Figure 4.3).

Table 4.7 shows the significant predictor terms and the fit of the models for the calibration and full periods of data. The pre-clearing models, except for storm-flow volume, are simple, containing only the control catchment equivalent of the independent variable as predictor. After clear-felling initial discharge (an indicator of catchment wetness) and precipitation became significant predictors in the models for the storm-flow variables. This indicates that the catchment was more responsive to antecedent wetness and rainfall.

As would be expected, weekly stream-flow was also significantly increased by clear-felling (Table 4.4). Clear-felling caused a significant increase in total flow as early as 1979 when less than half the plantation had been felled (Figure 4.6). In this year the increase over the expected flows was $94 \mathrm{~mm}$ (19\%) and the increase became steadily larger, peaking over the three years 1981 to 1983 when the annual increase averaged $237 \mathrm{~mm}$ (a $96 \%$ increase). By 1985 water yield was still significantly greater than expected, but clearly approaching the pre-treatment condition. The magnitude of the total flow increases following clear-felling agree closely with the yield decreases measured following initial afforestation. The water yield decline in Bosboukloof between the 16th and 39th years after afforestation was estimated to average $201 \mathrm{~mm}$ per year (Nan Wyk, 1987). 
Table 4.4 Significant $(a<0.05)$ predictor terms in the multiple regression models for the Bosboukloof catchment developed over the pre-clearing and full periods of streamflow data. The presence of the clear-fell dummy variable $(F)$ in the full models indicates a significant effect of felling.

\begin{tabular}{|c|c|c|c|c|c|c|}
\hline \multirow{2}{*}{$\begin{array}{l}\text { Dependent } \\
\text { variable }\end{array}$} & \multicolumn{3}{|c|}{ Calibration period (before clearing) } & \multicolumn{3}{|c|}{ Full measurement period } \\
\hline & $\begin{array}{l}\text { Significant } \\
\text { predictor } \\
\text { terms }\end{array}$ & $\begin{array}{l}\text { Error } \\
\text { d.t. }\end{array}$ & $\begin{array}{l}\text { Adjusted } \\
\mathbf{R}^{\mathbf{2}}\end{array}$ & $\begin{array}{l}\text { Significant } \\
\text { predictor } \\
\text { terms }\end{array}$ & $\begin{array}{l}\text { Error } \\
\text { d.f. }\end{array}$ & $\begin{array}{l}\text { Adjusted } \\
\mathbf{R}^{\mathbf{2}}\end{array}$ \\
\hline Weekly stream-flow & $\mathrm{C}, \mathrm{S}$ & 108 & 0.98 & $C, S, F$ & 470 & 0.89 \\
\hline Storm-flow volume & $C, P, Q_{1}$ & 24 & 0.98 & $C, P, Q_{1}, F$ & 53 & 0.98 \\
\hline Quick-flow volume & $\mathrm{C}$ & 24 & 0.97 & $C, P, Q_{i}, F$ & 53 & 0.97 \\
\hline Peak discharge & $\mathrm{C}$ & 24 & 0.89 & $C, Q_{i n} F$ & 54 & 0.91 \\
\hline Response ratio & C & 24 & 0.94 & $C, Q_{i,} F$ & 53 & 0.91 \\
\hline
\end{tabular}

Key: $\mathrm{C}=$ the corresponding control catchment variable

$\begin{array}{lll}\mathrm{S}, \mathrm{F} & = & \text { dummy variables for season and clear-felling respectively } \\ \mathrm{P} & = & \text { storm precipitation }(\mathrm{mm}) \\ \mathrm{Q}_{1} & = & \text { initial discharge }\left(\mathrm{mm} \text { day }{ }^{\prime}\right)\end{array}$

The total flow increases following clear-felling were larger than those measured following the fire. This resulted from the fact that the fire burned a young plantation which did not have the full water consumption of the mature plantation which was logged. It can be seen from Figure 4.6 that stream-flow in Bosboukloof over the period 1984 and 1985 was above that expected from a mature plantation. Yet this was the period used as calibration for the fire treatment and hence stream-flow increases as a result of fire were being measured against a fairly high base level.

It is postulated that the significant increases in storm-flow variables following clear-felling relate to the generally higher wetness of the catchment during and following clearing (Figure 4.6), and the consequently larger variable source area during rainstorms. In contrast to the effect of fire on storm-flow variables, however, clear-felling caused only small increases. After fire the storm-flows were both larger and showed larger increases: three to four fold in the first post-fire year, and roughly double in the second year (Table 4.2). After clear-felling the equivalent increases were of the order of a half and a third larger than expected (Table 4.5). 


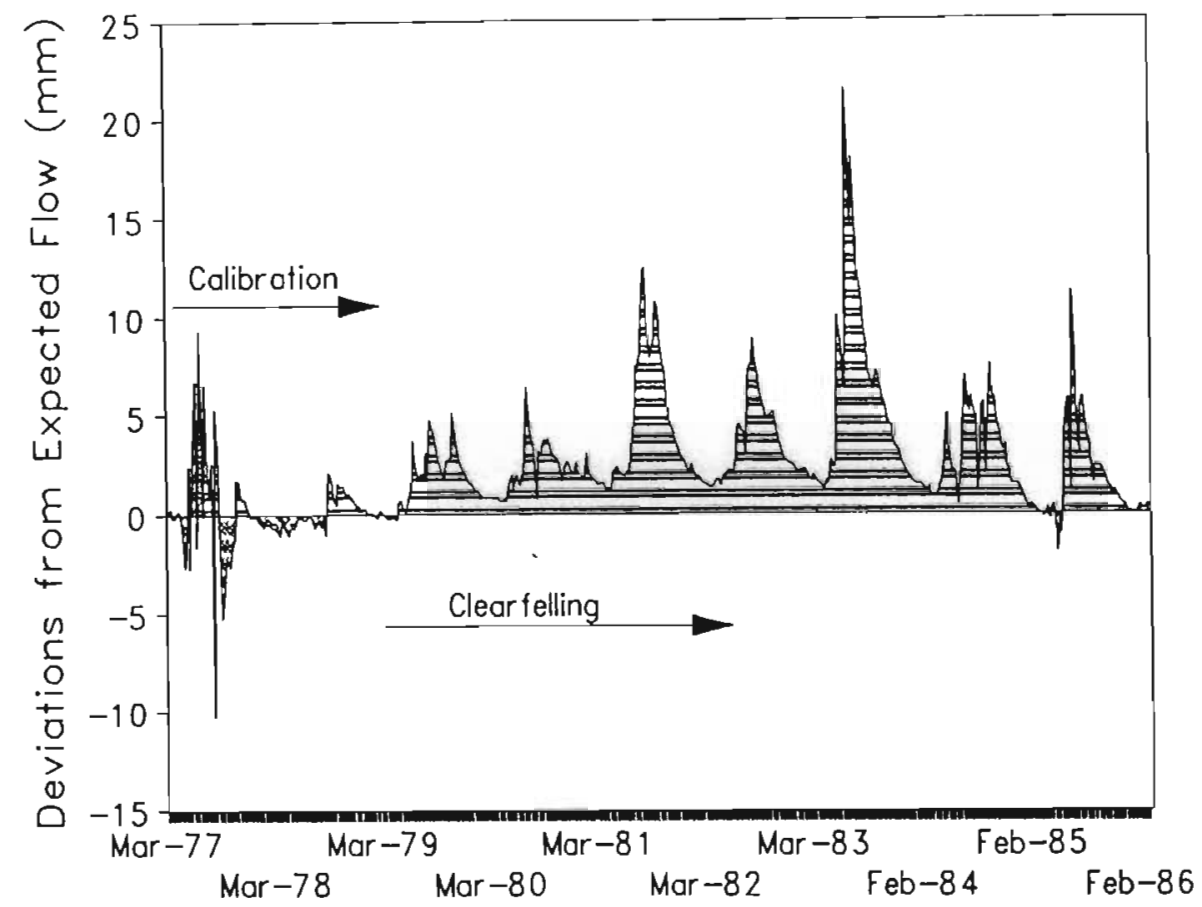

Figure 4.6 A time plot of the difference between the observed and expected weekly stream-flow in Bosboukloof over the calibration, felling and post-felling periods.

Table 4.5 Increases in stream-flow variables as a result of clear-felling of timber plantations in the Bosboukioof catchment.

\begin{tabular}{lcccccccc}
\hline $\begin{array}{l}\text { Stream-flow } \\
\text { variables }\end{array}$ & $\begin{array}{c}\text { Recorded pre- } \\
\text { felling } \\
(1977,78)\end{array}$ & $\begin{array}{c}\text { Recorded in } \\
\mathbf{1 9 8 1}\end{array}$ & $\begin{array}{c}\text { Change over } \\
\text { expected value }\end{array}$ & $\begin{array}{c}\text { Recorded in } \\
\mathbf{1 9 8 2}\end{array}$ & $\begin{array}{c}\text { Change over } \\
\text { expected } \\
\text { value }\end{array}$ \\
\cline { 2 - 9 } & mean & $\mathbf{n}$ & mean & $\mathbf{n}$ & & mean & $\mathbf{n}$ & \\
\hline $\begin{array}{l}\text { Weekly stream-flow } \\
\text { (mm) }\end{array}$ & 11.1 & 112 & 8.9 & 52 & $97 \%$ increase & 6.8 & 52 & $102 \%$ increase \\
Storm-flow (mm) & 6.9 & 29 & 2.7 & 20 & $25 \%$ increase & 1.8 & 13 & $18 \%$ increase \\
$\begin{array}{l}\text { Quick-flow volume } \\
(\mathrm{mm})\end{array}$ & 1.8 & 29 & 0.9 & 20 & $62 \%$ increase & 0.6 & 13 & $37 \%$ increase \\
$\begin{array}{l}\text { Peak discharge } \\
\text { (mm/day) }\left(\mathrm{m}^{3} / \mathrm{s}\right\}\end{array}$ & $\begin{array}{l}6.8 \\
\text { (0.16\} }\end{array}$ & 29 & 5.8 & 20 & $53 \%$ increase & 3.1 & 13 & $30 \%$ increase \\
Response ratio $(\%)$ & 2.5 & 29 & 2.3 & 20 & $70 \%$ increase & 1.2 & 13 & $36 \%$ increase \\
\hline
\end{tabular}




\subsection{DISCUSSION AND SYNTHESIS}

\subsubsection{Soil Wettability}

The layered appearance of water repellency in the soils of Bosboukloof after fire was quite marked, and agreed with descriptions of fire-induced repellency reported in California and Oregon (DeBano, 1981; Dyrness, 1976). The terms "dusty footprints in the mud" and "tinroof effect" (explained in Section 2.1.2.3) aptly describe the obviously layered repellency seen in the burnt site. Soil profiles exposed during or after rain showers clearly showed the water running out of the saturated surface soil and trickling over the dry sub-surface layer without wetting it, while lower in the profile the soil appeared to be normal (moist and wettable).

The layering of wet, dry and then wet soils is explained by the theory of the process of fireinduction of repellency of DeBano and Krammes (1966) as detailed in Section 2.1.2.3 and illustrated in Figure 2.3. The low frequency of occurrence of repellency in the surface layers of the burned soils (Figure 4.1) results from sufficient heating of the soil during a fire, which denatured or vaporised the hydrophobic, organic coatings (DeBano, 1966), leaving the soil wettable. Field observations showed that soil which was ashed (blackened by the fire) was especially wettable. Below the surface $10-30 \mathrm{~mm}$, soils were severely repellent (Figure 4.1), presumably due to intensification of incipient repellency and distillation of repellent substances which had been vapourised higher up in the profile (cf. Section 2.1.3.3). The decreasing frequency of repellency below $100 \mathrm{~mm}$ (Figure 4.1) probably results from the fact that at these depths in the profile heating was not sufficient to have any effect on the wettability of the soil.

The amount of soil heating which occurred during the Bosboukloof fire appears to have been a controlling factor in the development of water repellent soils. There are a number of variables which determine soil heating. First among these is antecedent soil wetness with its effect on the heat capacity and conductivity of the soil (Hillel, 1980). When a soil is dry, as was the case before the Bosboukloof fire, it has a relatively low heat capacity and conductivity, so that the same amount of energy can raise its temperature to a much greater extent. Also significant in the Bosboukloof fire were the high fuel loads and low fuel moisture. These factors all contributed to greater soil heating which is postulated to have caused the widespread inducement of serious repellency. 


\subsubsection{Overland Flow and Soil Erosion}

The large amounts of hillslope soil erosion measured in the burned catchment were caused by overland flow generated by long duration, low intensity rain-storms. Water readily infiltrated the wettable surface soil but further percolation was impeded by the repellent layer. Percolation was active down gaps (e.g. burned-out roots and alongside rocks) in the layer of repellent soil. When the net water entry rate was lower than rainfall intensity, the surface soil layer eventually became saturated and, under such conditions, saturation overland flow was observed in Bosboukloof. This is the mechanism by which overland flow arose on soils which would otherwise appear to have an infiltrability well in excess of local rainfall intensities. A short spate of rainfall, of as little as $3 \mathrm{~mm}$, in the middle of an average rainstorm of $\sim 20 \mathrm{~mm}$ was enough to initiate overland flow.

The Bosboukloof fire consumed not only the overlying organic matter but also that which was incorporated in the top 2 to $15 \mathrm{~mm}$ of soil. This action of high-intensity fires is known to break down soil aggregates, thereby increasing the erodibility of the soils (DeBano et al., 1977; Giovannini and Lucchesi, 1983). Where the soil heating was greatest, as under the slash piles, fine roots in the surface soil and the root-stocks of sprouting plants (fynbos remnants), which would have impeded the removal of soil, were frequently consumed in the fire. In Bosboukloof this loose mixture of soil and ash was readily entrained by overland flow.

Overland flow tended to concentrate on the compacted logging paths which had resulted from the clear-felling operation, and on the road system where drains and culverts soon became blocked with sediment and organic debris. This concentrated flow probably exacerbated the erosion problem.

Catchment sediment yields had been known to increase after prescribed burning in fynbos catchments elsewhere in the south-western Cape mountains (Nan Wyk, 1982), but at orders of magnitude less than yields measured in Bosboukloof (cf. Table 2.1, row 2). The difference is seen as a consequence of a high-intensity as opposed to prescribed (lowintensity) burn, and of the greater erodibility of granite-derived as opposed to sandstonederived soils. 


\subsubsection{Stream-flow Generation in the Catchment}

The stream-flow results show that the fire caused a marked deterioration of the catchment's "control" of rainfall. The increase in peak discharge was greater than the increase in quickflow, indicating a steepening of the hydrograph. This inference is supported by an analysis of storm duration which showed that storm-flow duration was no longer after the fire than before. The increase in total stream-flow volume was mainly due to the increased stormflow, which in turn was composed largely $(92 \%)$ of increased quick-flow volumes; in short, a change to a more responsive catchment behaviour.

There is a striking similarity between the results of this study and one by Rycroft (1947) of stream-flow in the fynbos-covered Abdolskloof catchment in the Jonkershoek Valley (Figure 3.1). He found that in the three wet season months (May to July) following a fire in April, storm-flow volume, peak discharge, total stream-flow volume and flood heights were all significantly higher than pre-fire levels. The increases in total stream-flow were proportionately much smaller than the increases in storm-flow. Duration of storm-flows in the burnt catchment decreased, indicating a steepening of the hydrograph similar to that found in the present study. Rycroft (1947) considered autumn fires to be the cause of these dramatic storm-flow changes: "By the time winter rains set in, the regrowth of the vegetation is so slight that the plants are more or less ineffective in checking surface runoff". Pre-fire catchment behaviour had been restored by the second wet-season after the fire (Banks, 1964).

Storm-flows in 15 South African catchments were analysed by Hewlett and Bosch (1984). Bosboukloof had the lowest storm response ratio (a $2.2 \%$ mean from 204 storms), and they noted that the catchment appeared "to be almost bottomless in its capacity to store rain". In the first year after the 1986 fire the mean storm response was $7.5 \%$, a more than three-fold increase.

\subsubsection{Synthesis of the Results: The Process of Effects of Fire}

The magnitude of the observed storm-flow increase in Bosboukloof, and the steepening of the storm hydrograph, support the hypothesis of an increased overland flow contribution to total storm-flow. Water repellency in the burned soils caused overland flow under relatively low-intensity, buttong duration rain storms. The fire had cleared the soil surface 
of litter and other barriers to surface flow. The overland flow thus generated was able to collect, in many cases, on the roads and skid paths which, by contributing to the rapid delivery of surface water, became an extension of the channel system. On the other hand, surface water and associated sediment was stored in localised surface depressions, behind unburned logs and in burnt-out root and stump cavities.

Although only $80 \%$ of the catchment was burned, its hydrological behaviour changed markedly. Stream channels were widened and deepened. A forestry workshop and store were flooded twice. Roads were gullied and drains blocked. Resultant road and drain rehabilitation costs within the catchment were considerable. The potential for flood damage following larger fires thus has been amply demonstrated.

\subsubsection{Comparison of Clear-felling and Fire Effects}

The comparison between the effects of fire and clear-felling on the hydrological behaviour of the Bosboukloof catchment provides crucial support of the central hypothesis of this thesis. The much larger storm-flow increases after fire indicate the change in the streamflow generating mechanism in the catchment. The first year increase in total flow after fire was $70 \mathrm{~mm}$, of which $40 \mathrm{~mm}$ was an increase in quick-flow volume. Following clear-felling the overall increase in stream-flow was greater, but quick-flow volume formed a minor part of the increase. These results support the hypothesis that stream-flow generation changed after the wildfire and that surface runoff became an important component of storm-flow.

In this chapter the marked hydrological response to fire in the normally unresponsive Bosboukloof catchment has been quantified. Associated with the hydrological response was clear evidence of fire-induced water repellency in the pine afforested areas of the catchment. Comparison of the effects of clear-felling and fire has supported the hypothesis that water repellency in the soils caused the change in hydrological behaviour after fire. In none of the other catchment studies described later in this thesis was the evidence of fire-induced repellency as distinct or widespread. 


\section{CHAPTER 5}

\section{THE SWARTBOSKLOOF STUDY}

Unlike the other catchment studies described in this thesis, Swartboskloof burned in a carefully planned and executed prescribed fire. The Swartboskloof catchment had been set aside as a fynbos reserve after it burned in a wildfire in 1958. When it was planned to burn the catchment for the first time since its proclamation as a nature reserve, a cooperative study was set up to research the effects of a prescribed fire on numerous aspects of the catchment's ecology. Thus, an excellent opportunity to study the hydrological effects of fire, and water repellency in the soils as a possible mechanism for any response, was presented by the experimental burning of the Swartboskloof catchment. Fire-induced water repellency had already been recorded in the nearby Bosboukloof catchment (Chapter 4). Given

(i) that Swartboskloof had fairly coarse textured soils (see Section 3.1.1),

(ii) the intended season of burn (late summer = dry season), and hence the anticipated dry condition of the soil and fuels,

(iii) the amount of organic litter and humus on and in the soil, and the length of time litter had been in contact with the soil (i.e. the time since the last fire), and

(iv) the high fuel loads and high proportion of dead, down fuels,

it was expected that water repellent soils would develop on this catchment too. All the above factors would pre-dispose a soil to the development of water repellency (DeBano, 1981).

The hypothesis for hydrological response to fire as proposed in Chapter 2 was to be tested: water repellent soils in a steep catchment bared by fire would increase the probability of overland flow, causing increased storm-flows and water yield in general, and would be associated with increased sediment yields. This chapter reports on the findings of studies undertaken to test this hypothesis. Once again investigations were performed at three different scales:

(i) at the most detailed scale, soils were tested in situ for water repellency before and after fire; 
(ii) rainfall-generated overland flow was measured on small plots as a realistic measure of infiltration rates; and

(iii) stream-flow, storm-flow and sediment yield variables were analysed to assess the response of the whole catchment to fire.

\subsection{STUDIES OF SOIL WETTABILITY}

\subsubsection{Design and Analysis of the Soil Wettability Study}

Soil testing was performed in five vegetation - soil association units, which were selected by superimposing the Swartboskloof vegetation map (MacDonald, 1985) on the soils map by Lambrechts et al. (1986). Each of the five units covered a large area in the central and lower catchment, had high fuel loads and was in reasonable proximity to a perennial stream. These factors signify the hydrological importance of the units, as serious repellency was expected to ensure delivery of surface runoff to the stream channel. The basic features of the sampled vegetation-soil units are summarised in Table 5.1.

Within each of the five units, 15 sample points were visited in the two months before and the first six weeks after the fire, and on each visit soil wettability was measured at four depths in the soil profile, namely 5, 15, 75 and $150 \mathrm{~mm}$ (a total of 600 determinations). The same two tests, i.e. water drop penetration time (WDPT) and critical surface tension (CST), used in the Bosboukloof assessment of repellency were used here, the same field procedures were applied and repellency index (RI) classification performed (Section 4.1.1).

The results of the water repellency testing were analysed with an ANOVA for a split plot design (GENSTAT, 1987). This allowed for testing of differences due to depth, vegetationsoil type, fire and their interactions, using the WDPT and CST measures of repellency for separate analyses. For reasons set out in Chapter 4 (Section 4.1.1) the analysis was also repeated with the non-parametric Chi-squared test by comparing the frequency distributions of the RI scores for each depth, across treatments and vegetation-soil types. 
Table 5.1 The characteristic vegetation and soil features of the units in which repellency sampling was performed.

\begin{tabular}{|c|c|c|c|c|c|}
\hline $\begin{array}{l}\text { Vegetation/Soils types } \\
\text { Number and name }\end{array}$ & $\begin{array}{c}1 . \\
\text { Tall protea on Magwa }\end{array}$ & $\stackrel{2 .}{\text { Tall protea on Nomanci }}$ & $\begin{array}{c}3 . \\
\text { Tall protea on } \\
\text { sandstone Clovelly }\end{array}$ & $\begin{array}{l}4 . \\
\text { Tall protea on sand }\end{array}$ & $\begin{array}{l}5 . \\
\text { Riparian forest }\end{array}$ \\
\hline Physiognomy ${ }^{\circ}$ & high closed shrubland & high closed shrubland & high closed shrubland & $\begin{array}{l}\text { high closed } \\
\text { shrubland }\end{array}$ & $\begin{array}{l}\text { riparian high } \\
\text { forest }\end{array}$ \\
\hline Floristic dominants & $\begin{array}{l}\text { Protea nitida, } \\
\text { Cliffortia ruscifolia (1), } \\
\text { Cymbopogon marginatus (2), } \\
\text {.... plus those in next column }\end{array}$ & $\begin{array}{l}\text { Protea neriifolia (3), } \\
\text { Pteridium aquilinum, } \\
\text { Restio gaudichaudianus (4), } \\
\text { Aristea major, } \\
\text { Mexmuellera stricta }\end{array}$ & $\begin{array}{l}\text { Protea neriifolia, } \\
\text { P. repens, } \\
\text { Diospyros glabra, } \\
\text { Restio triticeus, } \\
\text { plus spp. } 1,2,3,4\end{array}$ & $\begin{array}{l}\text { as in adjacent } \\
\text { column left }\end{array}$ & $\begin{array}{l}\text { Brabejum stellatifolium, } \\
\text { Cunonia capensis, } \\
\text { llex mitis, } \\
\text { Rapanea melanophloeos }\end{array}$ \\
\hline Parent material $^{+}$ & mixed granite and sandstone & mixed granite and sandstone & sandstone (quartzite) & sandstone (quartzite) & Mixed alluvial material \\
\hline $\begin{array}{l}\text { Soil form and } \\
\text { series }^{+}\end{array}$ & $\begin{array}{l}\text { Magwa } \\
\text { (series undefined) }\end{array}$ & $\begin{array}{l}\text { Nomanci } \\
\text { Nomanci }\end{array}$ & $\begin{array}{l}\text { Clovelly } \\
\text { Mossdale }\end{array}$ & $\begin{array}{l}\text { Fernwood } \\
\text { Fernwood }\end{array}$ & $\begin{array}{l}\text { Unspecified } \\
\text { with high rock content }\end{array}$ \\
\hline Soil texture ${ }^{+}$ & sandy loam & sandy loam & loamy sand & sand & sand \\
\hline$\%$ Gravel in top $100 \mathrm{~mm}^{*}$ & $<10$ & $<5$ & $<50$ & $<10$ & $>50$ \\
\hline $\begin{array}{l}\text { \% Organic carbon in top } \\
100 \mathrm{~mm}\end{array}$ & 5.0 & 10.0 & 4.2 & 3.6 & 8.8 \\
\hline
\end{tabular}

Notes: - From MacDonald (1985)

- From Lambrechts et al. (1986) 


\subsubsection{Results of the Soil Wettability Study}

The results of the water repellency testing are presented schematically in Figure 5.1, from which the pattern of occurrence of repellent soils can be seen. The proportions of the 15 samples which fell into each of the three repellency classes at a specific depth in each vegetation-soil type are shown. The split plot ANOVA indicates that vegetation-soil type, fire, depth in the soil, and their interactions were significant effects. The pre-fire survey of soil wettability in mid-to-late summer shows that there was considerable water repellency in the soils (Figure 5.1). This was concentrated in the upper two layers sampled, in which the majority of soils were at least somewhat repellent. In the riparian forest (vegetation-soil type 5) repellency was more or less evenly distributed with depth below the surface, probably as a result of an even mixing of organic matter throughout the sampled depth. Repellency in the protea-on-Nomanci soil (vegetation-soil type 2), with its granite-influenced soils and high organic matter content, was significantly greater than on the other sampling units.

Fire burnt-off repellency in the upper $15 \mathrm{~mm}$ of soil in all but vegetation-soil type 4 , which was unchanged (Figure 5.1). Repellency increased at between 15-50 mm below the surface in vegetation-soil types 1 and 4, but was no worse at this depth in the other types. Below $50 \mathrm{~mm}$ in the soil, there was less water repellency after fire in vegetation-soil types $2,3,4$ and 5. At these levels reductions in repellency were minor. In short, the effect of the fire was to increase the wettability of surface soils, but overall there was limited evidence of increased repellency beneath the surface.

Field observations on the extent of soil heating by the fire, using guidelines given by Wells et al., (1979), indicated that relatively little serious heating of the soil had occurred during the fire, presumably because of high soil and litter water contents. In a majority of sites the insulating ground litter and duff had been consumed only partially. However, localised patches of soil had been burned and the incorporated organic matter consumed. After the first low-intensity rains these points showed the typical fire-induced repellency phenomenon termed the "tin-roof effect", where wettable surface soils lie on top of soils which are now strongly repellent (Section 2.1.2.3). Water saturates the upper soil but runs off when rainfall intensity exceeds the percolation rate. 


\section{Site number Before fire}

1

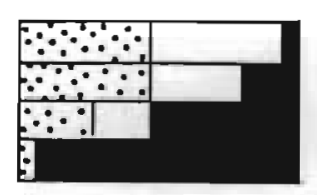

2

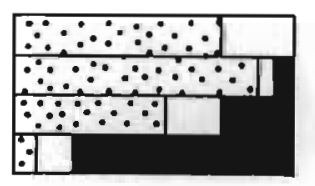

3

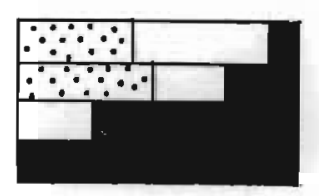

4

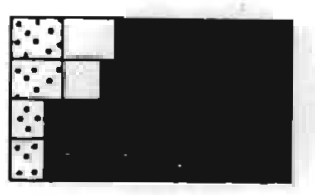

5

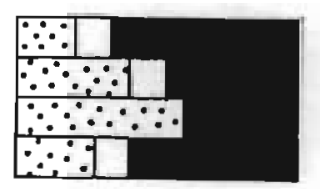

After fire
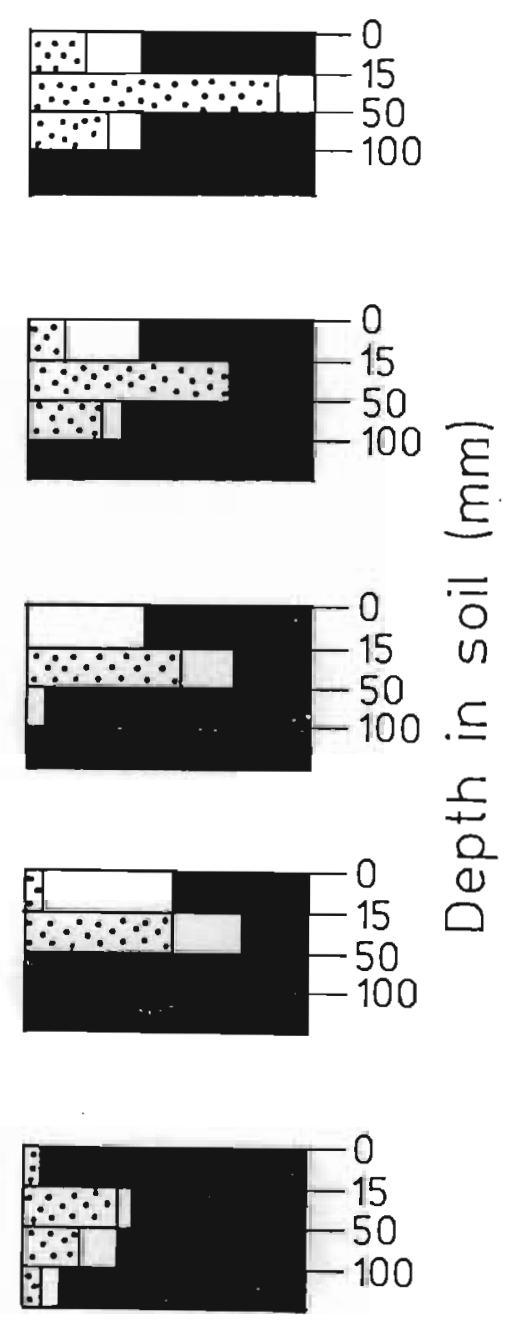

$\because \because$ Repellent

$\square$ Somewhat repellent

Wettable

Figure 5.1 A schematic representation of the soil wettability sampling results from Swartboskloof showing the proportion of 15 profiles at each depth in each repellency çlass before and after fire. 


\subsection{STUDIES AT THE PLOT SCALE}

\subsubsection{Layout of Overland Flow Plots}

At two hill-slope sites in Swartboskloof, each with gradients of 53\%, three adjacent plots of $3 \times 22 \mathrm{~m}$ were laid lengthwise down the slope. The sides and tops of each plot were formed by $1 \mathrm{~mm}$ thick flat sheet-iron hammered into the soil to a depth of 50 to $100 \mathrm{~mm}$. At the bottom of each plot, surface runoff was collected in a gutter and led to storage drums. Both sites were in tall proteoid shrubland, but site $A$ was on sandstone derived soils with a lower fuel load, while site $B$ was on granite derived soils (vegetation-soils types 3 and 1 respectively in Table 5.1) and had a higher fuel load (Table 3.3). In January 1988 a single unburned control plot was added to the experiment. This control plot was in 12 year old fynbos on a site in the adjacent Sosyskloof, similar to site A.

To test for the influence of soil heating on infiltration in the plots three fuel load treatments were applied to each set of three plots. All fuel on one plot was placed on to a second plot, so that on the first only fine ground fuels remained, while the second had almost a double fuel load. The third, and remaining, plot was left with its normal fuel load. Allocation of treatments was random. The total dry fuel load on the double fuel load treatment at site A was $3 \mathrm{~kg} \mathrm{~m}^{-2}$ whereas at site $B$ it was $7.5 \mathrm{~kg} \mathrm{~m}^{-2}$ of dry mass, with a mean fuel wetness at both sites of around 30\% (Table 3.3). The fuel loading treatments were completed a week before the fire, and in retrospect it appears that the fuel bed had not settled much before burning, so that the transfer of heat to the soil was very inefficient. All plots, however, were burned clean of all but the largest live fuels and some unincorporated organic matter on the soil surface.

The construction of the plots was completed after the fire and the plots were operating before the first major storms of the wet season. After each major rainfall event the plots were visited and the depth of rainfall and volume of overland flow were measured, and from a sample the suspended sediment was determined. Heavier sediments which collected in the gutter were collected by hand and their dry mass added to the sediment yield on a monthly basis. Maximum rainfall intensity over a 30 -minute period was measured with a single-day Casella recording raingauge maintained at the weather station at the foot of the Swartboskloof catchment. The variables used in the overland flow plot study and their mean values over the full study period are shown, by site, in Table 5.2. 
Table 5.2 Overall mean values, on a per storm basis, of the variables measured at the overland flow plots at sites $A$ and $B$ and the unburnt control plot. Standard deviations of the mean are given in brackets.

\begin{tabular}{lccccccc}
\hline Site & $\mathbf{n}$ & Rainfall & $\begin{array}{c}\text { Maximum } \\
\text { rainfall in } \\
\mathbf{3 0} \\
\text { minutes }\end{array}$ & $\begin{array}{c}\text { Depth of } \\
\text { overland } \\
\text { flow }\end{array}$ & $\begin{array}{c}\text { Overland } \\
\text { flow as } \\
\text { percentage } \\
\text { of rainfall }\end{array}$ & Soil loss & $\begin{array}{c}\text { Soil loss per } \\
\text { unit of rainfall }\end{array}$ \\
\hline Site A & 204 & 42.5 & 6.0 & 0.9 & 2.2 & 16.4 & \\
(3 plots) & & $(23.8)$ & $(2.8)$ & $(1.1)$ & $(2.1)$ & $(54.5)$ & $(8.92)$ \\
Site B & 201 & 43.2 & 5.9 & 1.8 & 4.5 & 57.4 & 8.80 \\
(3 plots) & & $(26.6)$ & $(2.8)$ & $(1.7)$ & $(3.5)$ & $(271.8)$ & $(38.09)$ \\
Control & 35 & 43.0 & 6.0 & 0.5 & 0.8 & 0.4 & 0.04 \\
& & $(25.4)$ & $(3.0)$ & $(0.8)$ & $(0.9)$ & $(1.3)$ & $(0.10)$ \\
\hline
\end{tabular}

After one year it was realised that an unburnt plot was required to serve as a control because the low-fuel load treatment had not fulfilled this function. For this reason the Sosyskloof plot was established.

The overland flow plot data were analysed by a multiple regression method using the SAS statistical package (SAS Institute, 1985). The intrinsically linear multiplicative model employed separately for the two dependent variables of overland flow depth and suspended sediment yield was

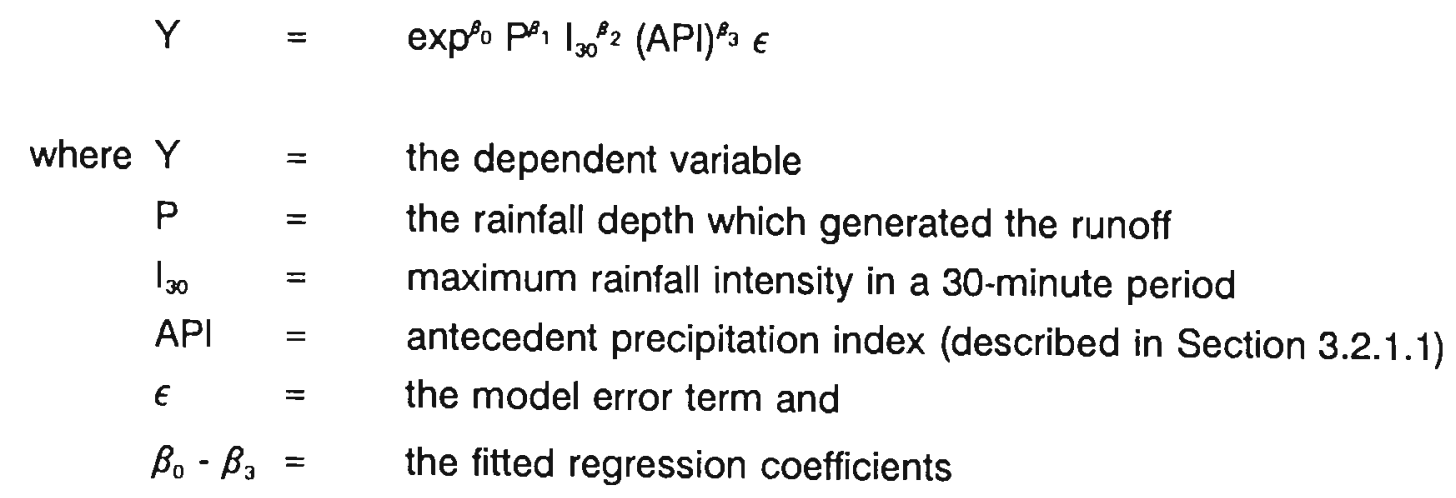

The test of treatment and site differences was done by means of the dummy variable technique (Section 3.2.1.2). 


\subsubsection{Overland Flow and Soil Erosion on Small Plots}

The prescribed fire caused marked increases in overland flow and sediment yield from the small plots. In the first year after the fire, mean runoff was 3.6 and $7.1 \%$ of rainfall and total sediment yield was 3.3 and $11.2 t$ ha $^{-1}$ for sites $A$ and $B$ respectively (Figure 5.2). In the single year of measurement in the unburned plot the corresponding figures were $0.8 \%$ runoff and $0.014 \mathrm{t} \mathrm{ha}^{-1}$. Increases due to the fire were therefore 342 and $782 \%$ for runoff, and 23800 and $81945 \%$ for sediment yield at sites $A$ and $B$ respectively.

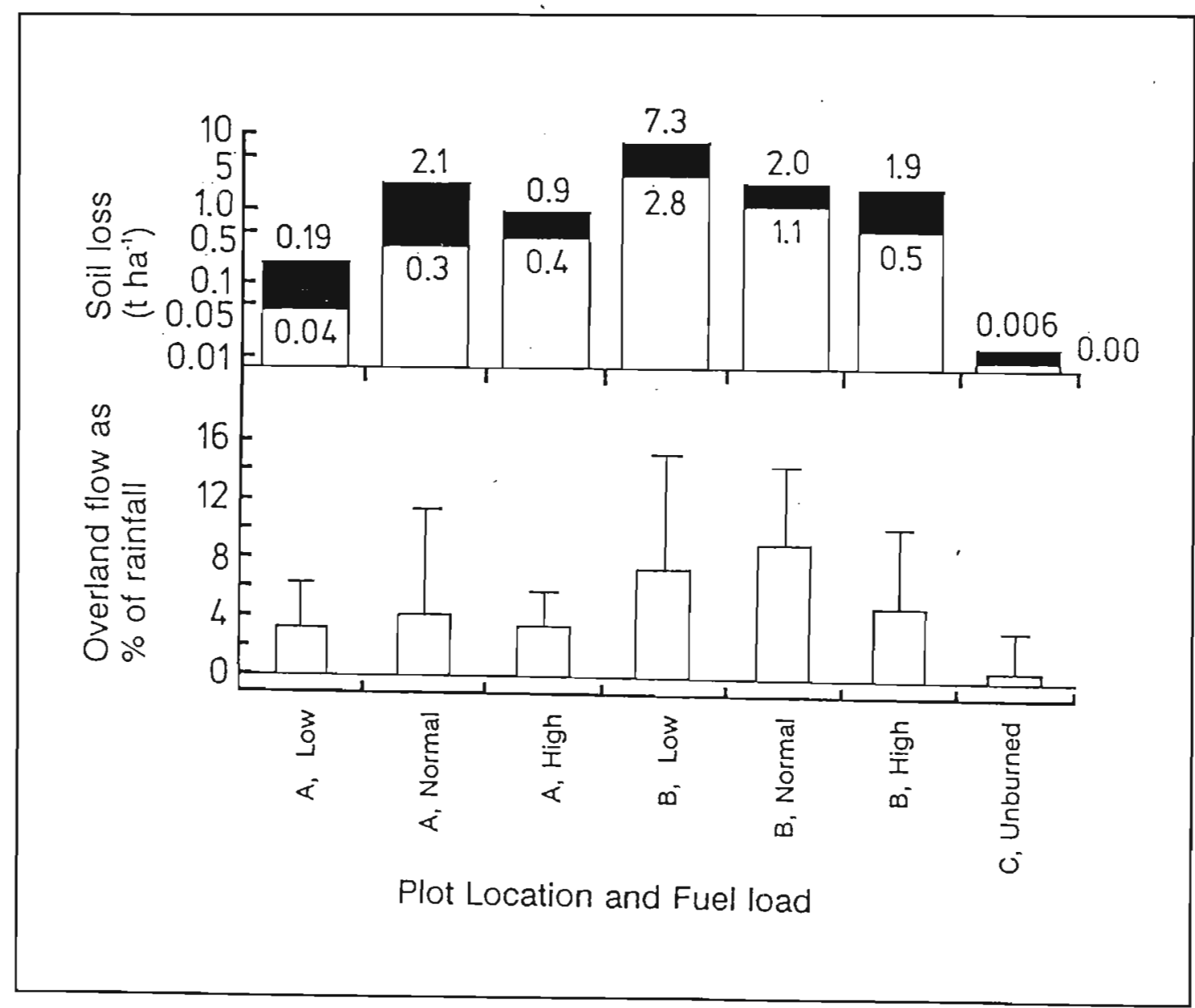

Figure 5.2 Maximum (open bar) and total (open plus solid bar) soil loss (note log scale), and mean (bar) and maximum (whisker) overland flow from seven plots in Swartboskloof in the first year of measurement.

On site B, with gravelly Magwa soils derived predominantly from granite and with higher clay and humus contents, there were significantly greater overland flow depths and sediment yields than at site $A$, in both years of measurement (Table 5.2). Runoff at site 
B was 97 and 165\% higher than at site A and sediment yield was 240 and $270 \%$ higher, in the first and second years after fire respectively, indicating a more rapid recovery at site A. Soils at site B showed greater water repellency, which had been induced in patches by fire, than did the sandstone-derived Clovelly soils at site A.

There were significant differences between responses on individual plots and, in the first year, between different fuel load treatments (Figures 5.2). But the differences were not in relation to fuel-loads (and hence the energy released during the fire), nor were they consistent for the same fuel-load treatment at the other site. It is therefore concluded that overland flow and sediment response from the small plots was related to characteristics of the specific plot and independent of the fuel loading treatments.

Water and sediment yields from the plots were significantly reduced in the second year after fire (Figure 5.3). Taken over the six plots jointly, the means were reduced from 5.6 to $1.2 \%$ overland flow (down $78 \%$ ), and from 2.4 to $0.06 \mathrm{t}$ ha.1 of sediment yield (down $97 \%$ ). In the second year overland flow from site $A$ was not significantly different from that of the unburnt control.

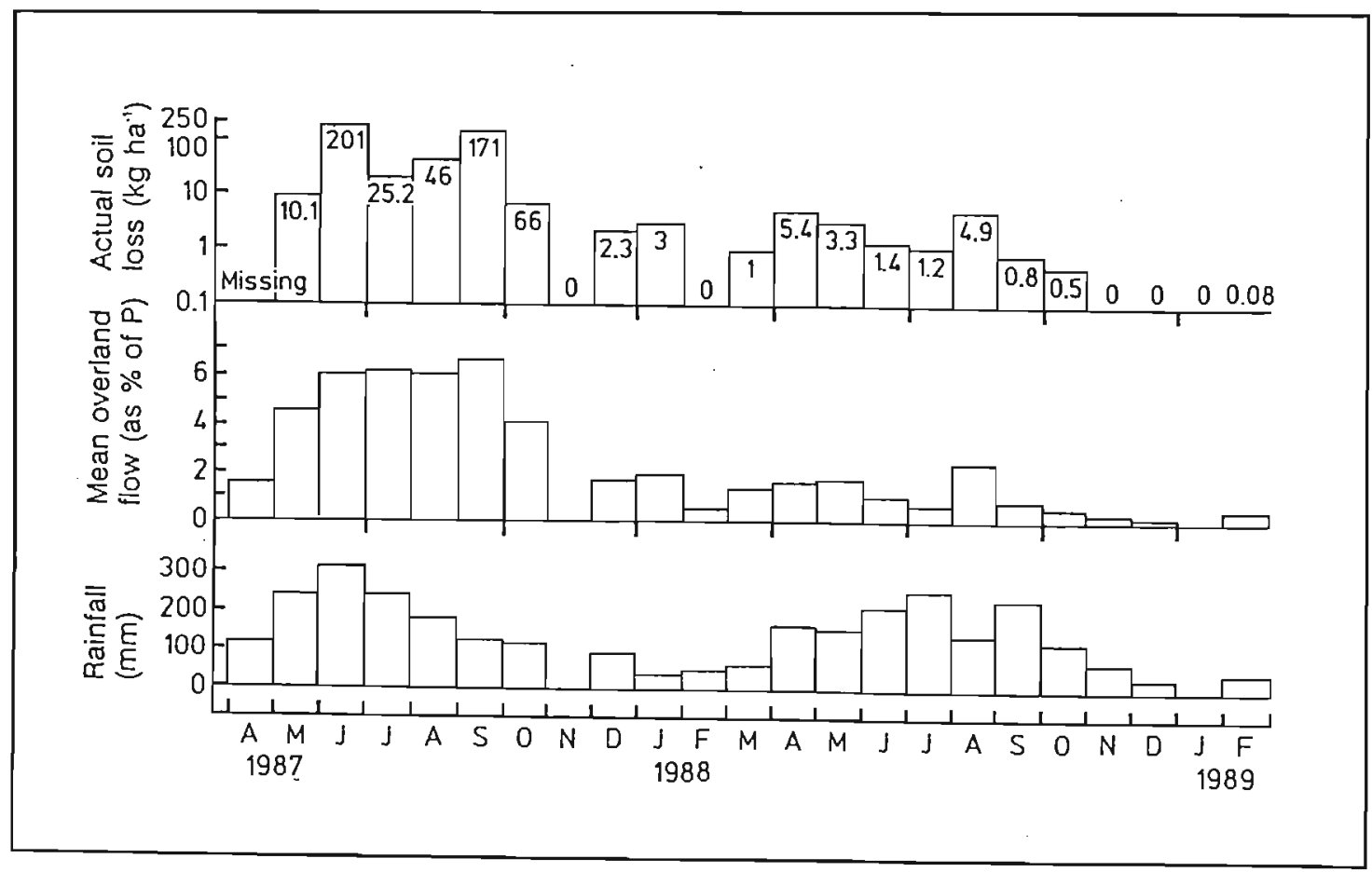

Figure 5.3 Mean monthly soil loss and overland flow depth (as percentage of rainfall, P) from six burned plots in Swartboskloof after fire in March 1987, showing marked reductions in the second year. 
The results of the regression analysis are summarised in Table 5.3 showing the poor fit of the models (low $R^{2}$ values), as well as the most useful predictors of overland flow and soil loss in order of importance. The correlations between the dependent and independent variables measured on the unburned plot are presented as an example of the relationships found in this study (Table 5.4). The significant positive relationships between rainfall depth and intensity, on the one hand, and overland flow and sediment yield for the unburned plot on the other, are typical. The unusual feature of the unburned plot was the negative relationship between antecedent wetness and runoff. On the burned plots this relationship was positive, as would be expected according to infiltration theory. The explanation for this unexpected behaviour of the unburned plot is that under dry conditions (low API) the soils are most water repellent, and this repellency causes a higher proportion of rainfall to be lost as surface runoff. This phenomenon has been recorded in sclerophyllous eucalypt forest in Australia by Burch et al. (1989) who noted that relatively more runoff was produced in a small catchment from rainfall events during dry periods.

Table 5.3 Best regression models for explanation of overland flow and soil loss from small plots in the Swartboskloof catchment.

\begin{tabular}{llccl}
\hline Dependent & Variable & $\begin{array}{c}\text { Error } \\
\text { df }\end{array}$ & $\begin{array}{c}\text { Adjusted } \\
\mathbf{R}^{2}\end{array}$ & $\begin{array}{l}\text { Significant predictor } \\
\text { variables }(\alpha<0.05)\end{array}$ \\
\hline First year & Overland flow & 161 & 0.77 & $\begin{array}{l}\text { rainfall, rainfall intensity, antecedent } \\
\text { wetness, plot }\end{array}$ \\
& Soil loss & 162 & 0.60 & $\begin{array}{l}\text { rainfall, rainfall intensity, antecedent } \\
\text { wetness, plot }\end{array}$ \\
Second year & Overland flow & 205 & 0.72 & $\begin{array}{l}\text { rainfall, rainfall intensity, antecedent } \\
\text { wetness, plot, season } \\
\text { rainfall, rainfall intensity, antecedent } \\
\text { wetness, plot }\end{array}$ \\
\hline
\end{tabular}

Table 5.4 Pearson correlation coefficients between dependent and independent variables for the single storms on the untreated control plot. The number of storm events in the sample was 35 over one year.

\begin{tabular}{lccc}
\hline \multirow{2}{*}{ Independent variables } & \multicolumn{3}{c}{ Dependent variables } \\
\cline { 2 - 4 } & $\begin{array}{c}\text { Depth of overland } \\
\text { flow }(\mathbf{m m})\end{array}$ & $\begin{array}{c}\text { Depth of overland } \\
\text { flow as \% of rainfall }\end{array}$ & Soil loss $(\mathrm{g})$ \\
\hline Rainfall depth & $0.71^{\cdots}$ & $0.49^{\cdots}$ & $0.48 \cdots$ \\
Max. 30-minute rainfall & $0.64 \cdots$ & $0.70^{\cdots}$ & $0.60 \cdots$ \\
Antecedent wetness & $-0.31^{\cdots}$ & $-0.48^{*}$ & $-0.33^{\circ}$ \\
\hline
\end{tabular}

$\because \cdot, \cdots$ indicates significance at the $\alpha<0.1,0.01$ and 0.001 probability levels respectively. 


\subsection{STUDIES AT THE CATCHMENT SCALE}

\subsubsection{Stream-flow}

\subsubsection{Establishing a calibration relationship}

The catchment water balance for the four years of record is shown as Figure 5.4, which shows the distribution of annual precipitation into quick-flow and base-flow. The low proportion of quick-flow (18.2\% of total stream-flow) is due to high infiltration rates, deep soils and low intensity rainstorms. The highest quick-flows are associated with large $(100+$ $\mathrm{mm}$ ) rain events in mid-winter, when the catchment is likely to be close to saturation. The percentage catchment response on an annual basis (mean annual runoff (MAR)/mean annual precipitation (MAP) $\times 100$ \} at $40 \%$ is fairly high, as would be expected of wellwatered mountain catchments in the winter rainfall region.

Compared to other Jonkershoek streams though, Swartboskloof's percentage response appears somewhat low, as shown in Figure 5.5. Two factors may explain this lower than expected catchment response. The stream in the vicinity of the gauging weir is expected to be highly influent as, firstly, there is a very steep hydraulic gradient (roughly $1: 15$ ) to the nearby, lower-lying Jubilee Creek and, secondly, the stream at this point traverses unsorted colluvial and alluvial boulder and rock deposits. Thus, an unaccounted leak from the catchment seems quite likely and would introduce an error into the calculation of the catchment water balance shown in Figure 5.4. In addition, the northerly (equatorial) aspect of Swartboskloof will cause a greater evaporative loss compared to the predominantly south-westerly aspects of the other gauged catchments in Jonkershoek. Both the aspect and leakage factors may contribute to the seasonally changing relationship between Swartboskloof and Tierkloof (Figure 5.6). 


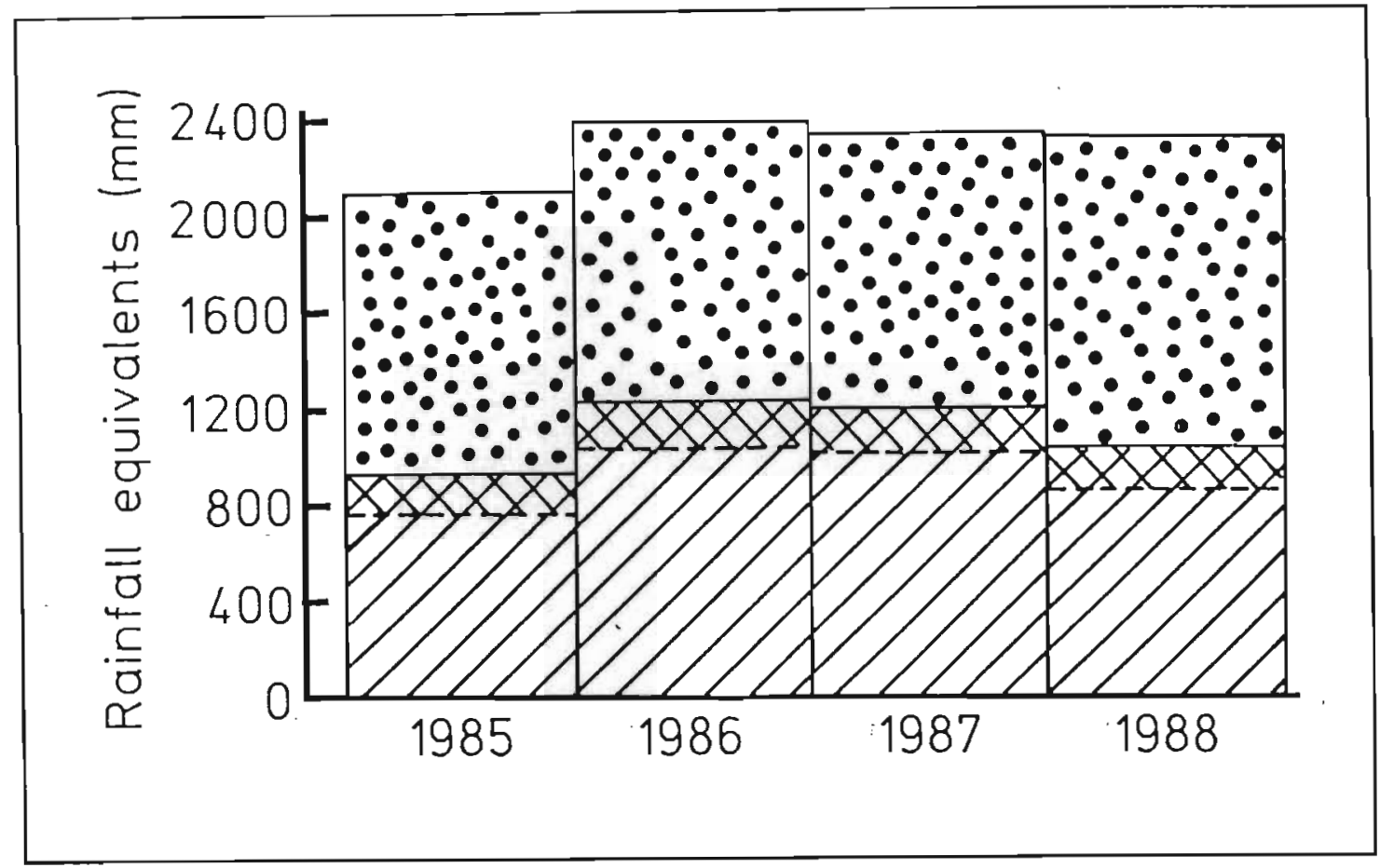

Figure 5.4 Annual water balance (for hydrological years) for the Swartboskloof catchment, estimated by mass balance over the available period of record. Height of the bar indicates annual precipitation, hatched is base-flow, crosshatched is quick-flow volume and dotted is residual (= evaporation).

The paired catchment method requires the pre-treatment calibration of the catchment to be treated (in this case Swartboskloof) against a similar but untreated catchment which serves as a control (Tierkloof). The stream-flow in Swartboskloof did not correlate particularly well with that in the potential control catchments (Tierkloof and LambrechtsbosB; Figure 5.6). Relative to these catchments, the dry season stream-flows in Swartboskloof are lower and the wet season flows are greater. Both Tierkloof and Lambrechtsbos-B were tested as control catchments and Tierkloof was selected as the better option. To account for the seasonal disparity between flows in the treatment and control catchments mentioned earlier, a dummy variable for season was also included in the stream-flow regression models. This dummy variable improved the fit of most of the models. Summing stream-flow over fortnightly periods reduced some of the difference between stream-flow in the two catchments seen over shorter summation intervals (Figure 5.6).

\subsubsection{Observable effects of fire on stream-flow}

Hydrograph components of 51 storm events in the two years after the fire were compared to results from 52 storms in the two years prior to the fire. The mean pre-fire values of the variables generated for thè storm-flow analysis are shown in Table 3.4. 


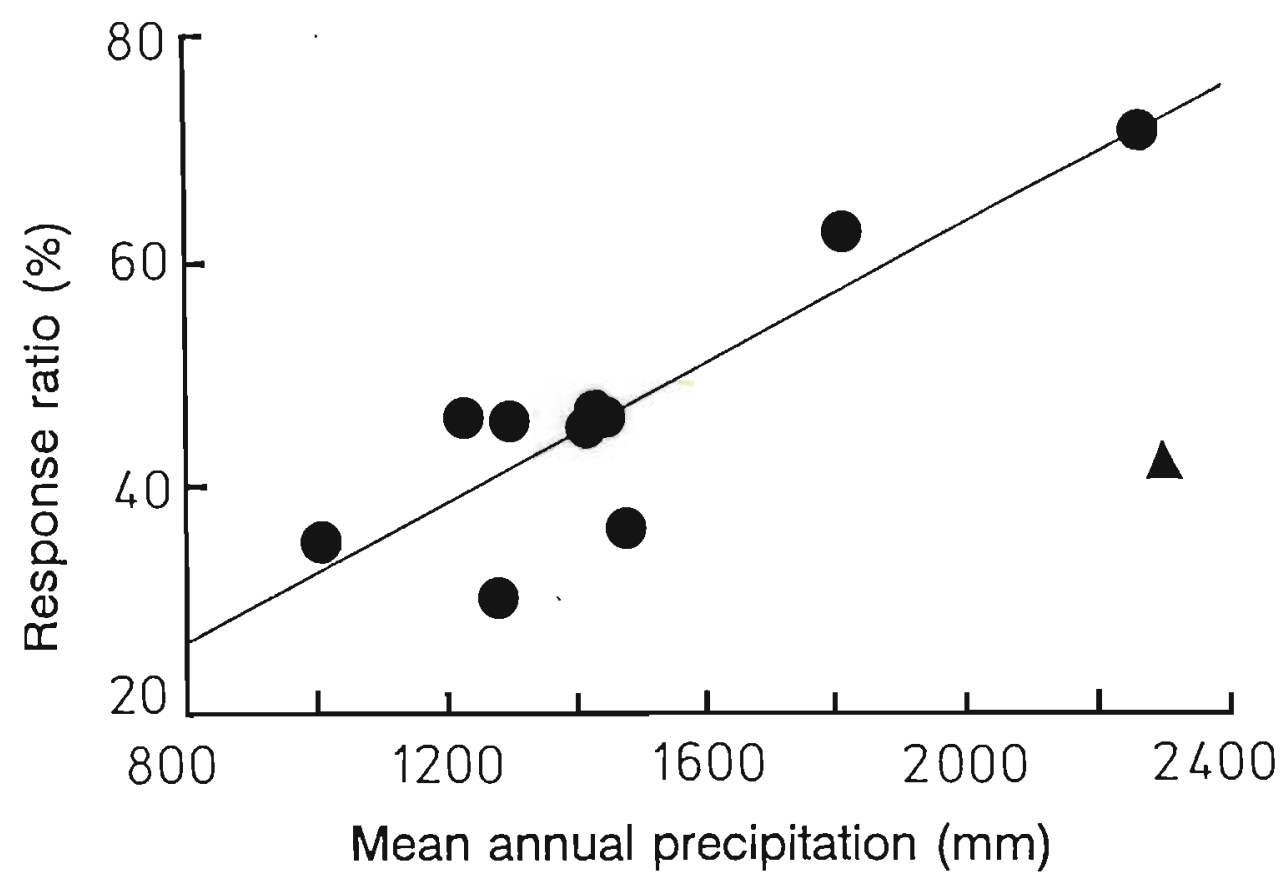

Figure 5.5 The annual response ratio for Jonkershoek catchments plotted against mean annual rainfall. Data are for the longest period available (mostly in excess of 20 years). Swartboskloof is indicated as a triangle.

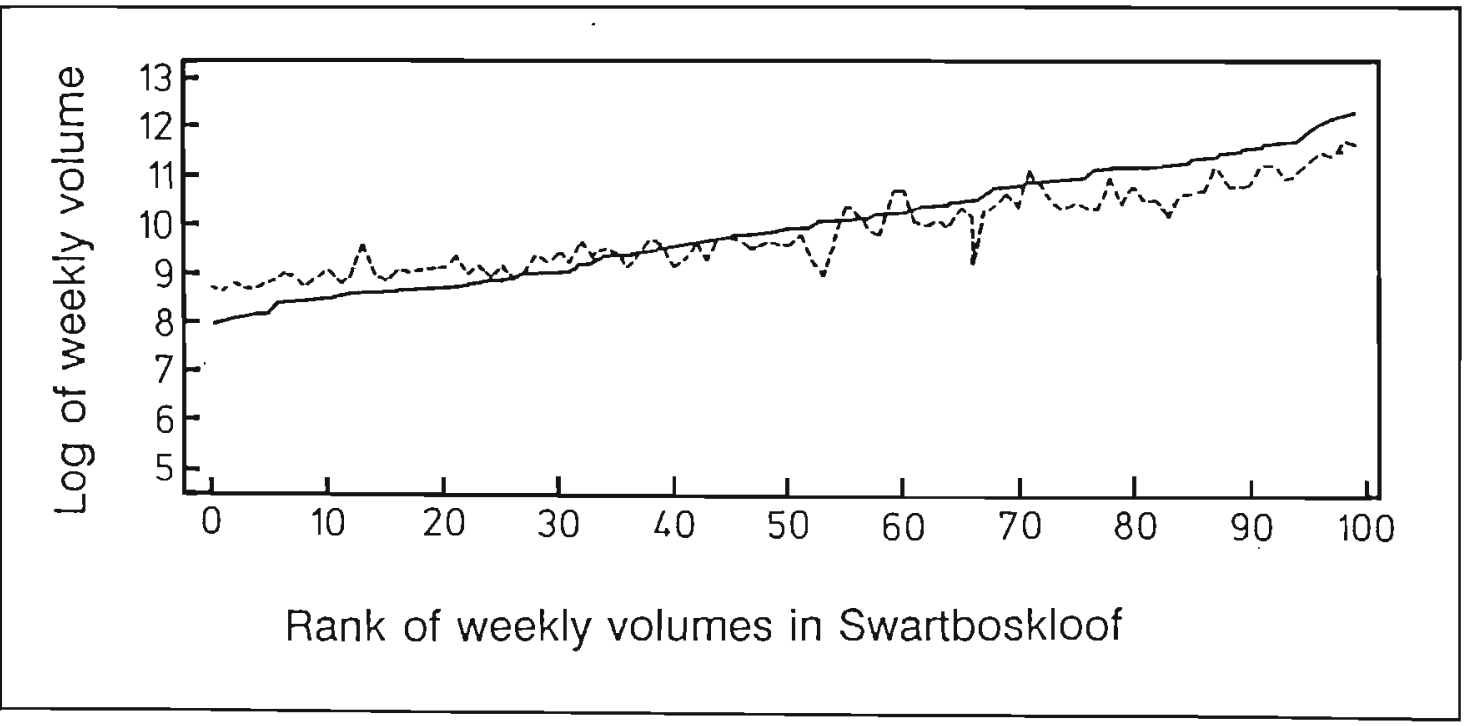

Figure 5.6 Weekly stream-flow volumes (log of $\mathrm{mm}$ values) in Swartboskloof ( - ) and the corresponding week's volume in Tierkloof (-) plotted against the rank of Swartboskloof volumes.

The total stream-flow showed a significant increase of $16 \%$ above the expected volume over the two years after the fire; $15 \%(79 \mathrm{~mm})$ in the first year and $17 \%(77 \mathrm{~mm})$ in the second. Catchment water yields in the two post-fire years were not different from each 
other. None of the storm-flow variables analysed showed a significant change after the fire. Deviations of, for example, the larger quick-flows in Swartboskloof about the calibration regression (Figure 5.7) show, firstly, a rather weak calibration model and, secondly, that though there are fairly large quick-flows above and below those expected, the pattern and size of these deviations is not changed by the fire.

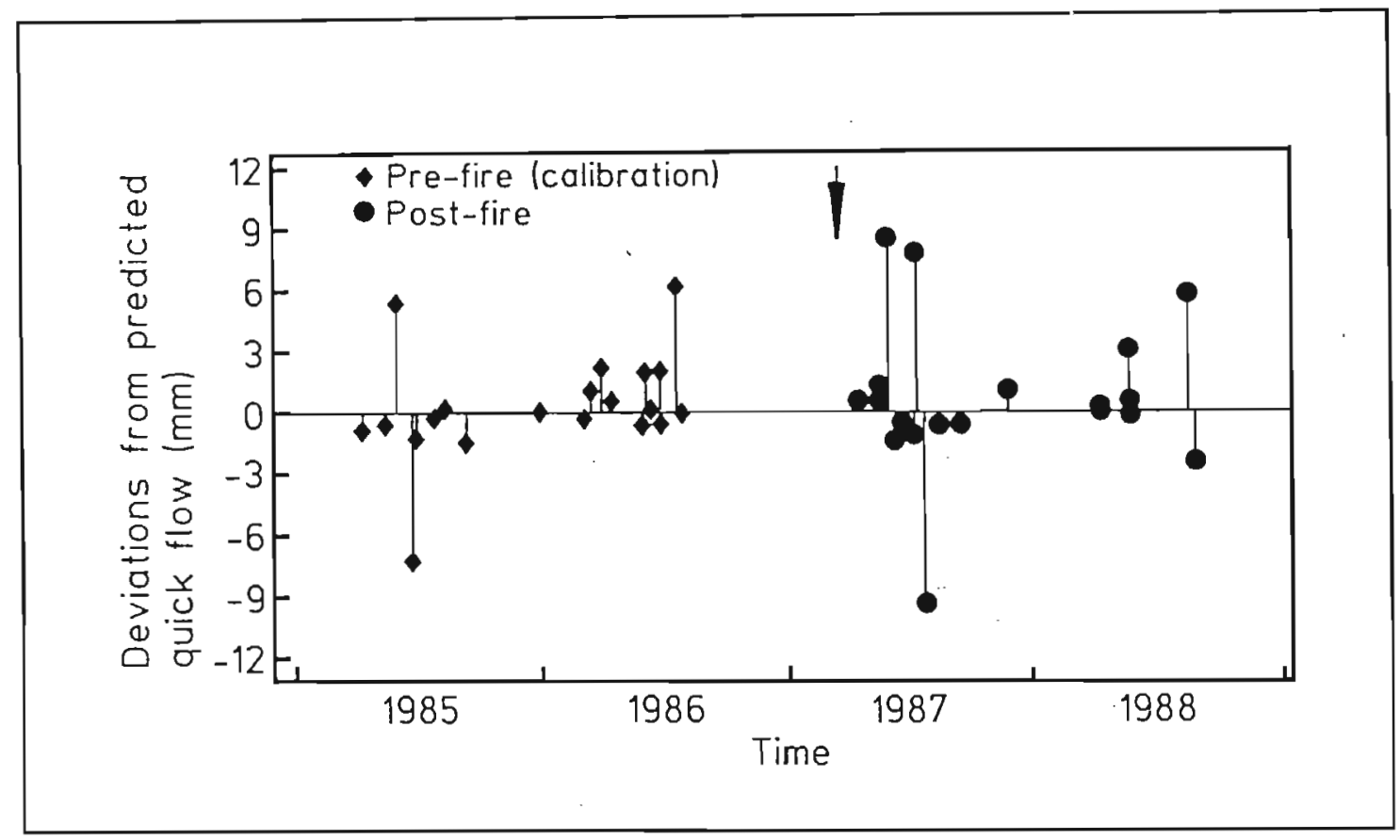

Figure 5.7 Differences between observed quick-flow volumes from the Swartboskloof catchment and predictions from the calibration equation.

The general fit of the calibration models is not particularly good (adjusted $R^{2}$ values from 0.80 to 0.95 ; Table 5.5). Consequently, small changes in the storm-flow variables as a result of fire could not have been shown as significant.

The control catchment (Tierkloof) provided relatively little explanation of storm-flows in Swartboskloof. The best calibration regression models all included storm duration, storm rainfall, rainfall intensity (over a 1 hour period rather than a 30 minute period) and the dummy variable for season (Table 5.5). Initial discharge was a significant "predictor" of storm- and quick-flow and response ratio both before and after the fire. 
Table 5.5 Details of the calibration (i.e. pre-fire), reduced and full multiple regression models for the stream-flow data in Swartboskloof.

\begin{tabular}{|c|c|c|c|c|c|c|c|}
\hline \multirow{2}{*}{$\begin{array}{l}\text { Dependent variable } \\
\text { (treatment catchment) }\end{array}$} & \multicolumn{3}{|c|}{ Calibration model } & \multicolumn{2}{|c|}{$\begin{array}{l}\text { Reduced model } \\
\text { (No fire terms) }\end{array}$} & \multicolumn{2}{|c|}{$\begin{array}{l}\text { Full model } \\
\text { (Fire terms included) }\end{array}$} \\
\hline & $\begin{array}{l}\text { Error } \\
\text { df }\end{array}$ & $\begin{array}{l}\text { Adjusted } \\
\mathbf{R}^{2}\end{array}$ & $\begin{array}{l}\text { Significant } \\
\text { predictors } \\
(P<0.05)\end{array}$ & $\begin{array}{l}\text { Error } \\
\text { df }\end{array}$ & $\begin{array}{l}\text { Adjusted } \\
\mathbf{R}^{2}\end{array}$ & $\begin{array}{l}\text { Error } \\
\text { df }\end{array}$ & $\begin{array}{l}\text { Adjusted } \\
\mathbf{R}^{2}\end{array}$ \\
\hline $\begin{array}{l}\text { Fortnightly stream-flow } \\
\text { volume }\end{array}$ & 48 & 0.94 & $\mathrm{C}, \mathrm{s}$ & 100 & 0.92 & 98 & 0.93 \\
\hline Storm-flow & 34 & 0.95 & $\begin{array}{l}D, P, Q, I_{000} \\
S\end{array}$ & 62 & 0.96 & 49 & 0.96 \\
\hline Quick-flow & 34 & 0.91 & $\begin{array}{l}D, P, Q_{1}, b_{80} \\
S\end{array}$ & 62 & 0.91 & 49 & 0.92 \\
\hline Peak discharge & 35 & 0.85 & $I_{s o l}, D, P, S$ & 62 & 0.85 & 49 & 0.86 \\
\hline Response ratio & 37 & 0.80 & $D_{1} b_{80}, Q$ & 64 & 0.82 & 52 & 0.83 \\
\hline
\end{tabular}

$\begin{array}{lll}\text { Key: } \quad \text { C } & = & \text { the corresponding control catchment variable } \\ \text { S } & = & \text { dummy variable for season } \\ D & = & \text { storm duration }(\mathrm{h}) \\ \mathrm{P} & = & \text { storm precipitation }(\mathrm{mm}) \\ \text { lo }_{80} & = & \text { maximum rainfall }(\mathrm{mm}) \text { over } 1 \mathrm{~h} \text { period } \\ \mathrm{O}_{i} & = & \text { initial discharge }(\mathrm{mm} \text { day }\end{array}$

\subsubsection{Sediment Yields}

Monthly sediment yields (Figure 5.8) for 21 months after the fire were compared with those for 15 months before the fire by the non-parametric Wilcoxon-Mann-Whitney test. There was no significant difference in total or storm-flow generated sediment yield due to burning (Table 5.6), though there was a significant increase in sediment yield during base-flows (Scott and Van Wyk, 1992). Since sediment export occurs mainly during spates (95\% in the three years of this study), an ANOVA was performed on the trend of sediment concentrations in storm-flows in Swartboskloof. The test indicated that there was no significant increase in the sediment concentration after the fire (Scott and Van Wyk, 1992). Sediment yields were dominated by single events or clusters of closely-spaced storm events; for example, the sediment yield in the particularly wet August $1986\left(0.57 \mathrm{t} \mathrm{ha} \mathrm{a}^{-1}\right)$ contributed $81 \%$ of the annual total and was greater than subsequent annual totals $(0.41$ and $0.15 \mathrm{tha}^{-1}$ ).

Bedload was measured once a year by determining the volume and bulk density of material accumulated in the stilling pond above the weir. From 1986 to 1988 annual yields were estimated as 11.8, 11.6 and $15.1 \mathrm{~kg} \mathrm{ha}{ }^{-1}$ respectively (Scott and Van Wyk, 1992), which is in the range of one fortieth to one tenth of the suspended sediment yields. 


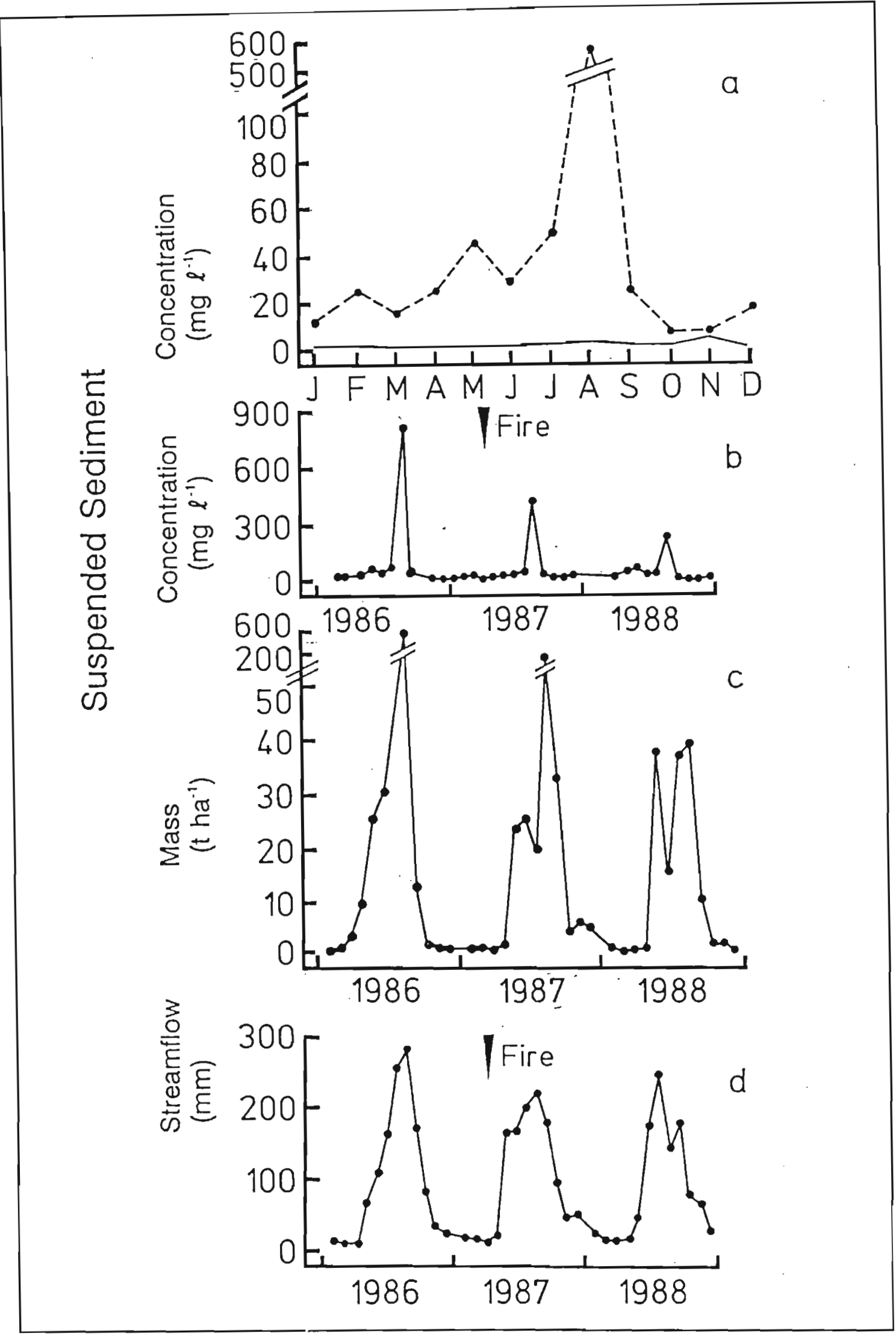

Figure 5.8 Monthly suspended sediment export from Swartboskloof: (a) averaged over three years, (b) mean concentration, (c) mass and (d) corresponding streamflow volume (Scott and Van Wyk, 1992). 
Table 5.6 Results of the non-parametric Wilcoxon-Mann-Whitney test of pre-fire (January 1986 to February 1987) against post-fire (April 1987 to December 1988) monthly sediment yield (Scott and Van Wyk, 1992).

\begin{tabular}{lcccc}
\hline & $\mathbf{Z}$ & Prob. $>|\mathbf{Z}|$ & $\begin{array}{c}\text { Pre-fire mean } \\
(\mathrm{kg} \mathrm{ha})\end{array}$ & $\begin{array}{c}\text { Post-fire mean } \\
(\mathrm{kg} \mathrm{ha})\end{array}$ \\
\hline Base-flow & -2.278 & 0.023 & 1.04 & 2.16 \\
Storm-flow & -0.706 & 0.480 & 45.57 & 24.18 \\
Total flow & -1.187 & 0.235 & 46.34 & 26.34 \\
\hline
\end{tabular}

\subsection{DISCUSSION AND SYNTHESIS}

\subsubsection{Soil Wettability}

Water repellency occurred generally in the upper $50 \mathrm{~mm}$ soil in the late summer before burning, when the pre-fire sampling was undertaken. This was not unexpected, given the pre-disposing factors of coarse texture, dry conditions, high organic matter content, and time since the last fire. While there is good ground cover and, other than repellency, favourable physical conditions for infiltration, the inherent repellency is unlikely to influence hydrological behaviour on a large scale.

Plant litter is the source of hydrophobic substances which transfer into soil by incorporation of organic matter, by leaching downward over time, or by vapour transport during burning (DeBano and Krammes, 1966; Savage et al., 1972). Thus it was to be expected that the soils with a organic matter content, in this sample the Magwa and Nomanci forms, would show more repellency than those with a lower organic matter content, e.g. the Clovelly soil. As organic matter content decreases at greater depths in the soil so water repellency will become less too, causing the significant differences due to depth in the profile. The lower frequency of fire in the riparian forest and the incorporation of partially decomposed plant matter to greater depths in the soil profile, explain the high repellency ratings to greater depths than under the more regularly burned vegetation types.

The heating of the soils is reflected most in the increased wettability of the surface layer. The organic compounds responsible for hydrophobic behaviour of the soil are destroyed or denatured by excessive heating. The cause of layering of water repellency in the soils through heating of the soils is explained in Sections 2.1.3.3 and 4.5.1. The results show 
that typical fire-induced repellency occurred more obviously in the Magwa, Nomanci and Fernwood soil forms, though in the field we observed that this pattern, though never continuous, was present in most of the cleanly burned sites.

Soil wetness is critical in determining the amount and spread of soil heating which takes place during a fire. Dry soils are heated more than wet soils because water greatly increases their heat capacity and conductivity (Hillel, 1980). The unseasonably high rainfalls in February and March would have greatly reduced the potential for soil heating during the fire on March 17. The riparian zones were little affected by the fire, as a result of their more mesic nature and the higher moisture levels of their soils. Minimising damage to riparian areas may be an important key in controlling fire effects.

As water repellent soils gain in soil water content so they become more wettable (DeBano et al., 1967; Gilmour, 1968). The lower post-fire repellency ratings below $50 \mathrm{~mm}$ in the soil (Figure 5.1) may be an artefact of the moister soil conditions prevailing during the post-fire soil survey. This factor may also explain the apparent absence of fire-induced repellency in the $15 \mathrm{~mm}$ to $50 \mathrm{~mm}$ depth layer in the soil. Regardless of the degree of repellency present in any vegetation-soil type, there were frequent patches of soil which showed no repellency, and these could have accommodated water from areas where percolation was impeded.

\subsubsection{Overland Flow and Soil Erosion}

\subsubsection{Factors controlling overland flow and soil loss.}

The high overland flow rates after fire on steep slopes, ranging in response from 3.1 to $8.8 \%$ of rainfall (Figure 5.2), are greater than would be expected from an examination of the physical soil properties (texture, porosity, bulk density), plot slope and rainfall intensities. These runoff rates were, as expected from theory, positively related to the rainfall depth and intensity, as well as to antecedent wetness. Similarly, sediment yields were related to these factors, but were an exponential function of the amount of runoff produced on the plot. The high levels of overland flow indicate that infiltration and/or percolation on steep slopes was inhibited, most likely by water repellent soils.

The high overland flow measured in this study, even off the control plot, are in sharp contrast to the almost negligible runoff response $(0.05 \%$ of rainfall) recorded from gentler 
sloping (25\%) plots elsewhere in the Jonkershoek Valley Nersfeld, 1981) where none of the treatments of hoe, slash and burn, or thinning of pine plantation had a significant effect. Soil losses off burned plots in this study were similar to the 0.4 to $7.8 \mathrm{tha}^{-1} \mathrm{a}^{-1}$ measured from untreated plots in the San Gabriel Mountains of California by Anderson et al. (1959), the 2.8 to $7.3 \mathrm{t} \mathrm{ha}^{-1} \mathrm{a}^{-1}$ reported from prescription burned plots at Santa Maria, California (DeBano and Conrad, 1976), and the 2.5 to $8.2 \mathrm{t} \mathrm{ha}{ }^{-1}$ measured from gentler (21\%) slopes in New South Wales, Australia by Blong et al. (1982) after a moderate intensity wildfire (Table 2.2). By comparison, the soil losses measured in nearby Bosboukloof (Chapter 4) were considerably higher $\left(10-26 \mathrm{t} \mathrm{ha}^{-1}\right)$. More extreme events have been reported in

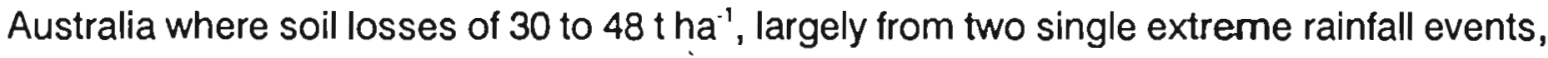
were measured in the first three months after a wildfire (Atkinson, 1984), and in California where a high soil loss of $346 \mathrm{t} \mathrm{ha \cdot 1} \mathrm{a}^{-1}$ was reported from the San Gabriel Mountains (Krammes and Osborn, 1969).

\subsubsection{Recovery with time after disturbance}

The reductions in overland flow and sediment yields in the second year after fire of $78 \%$ and $97 \%$ respectively (Figure 5.3) were almost as marked as the post-fire increases. At site $A$ overland flow in the second year had virtually recovered to a pre-fire state, and was no longer significantly different from the control. Although these reductions were accompanied by a rapid recovery of sprouting vegetation on the plots, mainly bracken, Pteridium aquilinum, and the geophyte Watsonia pyramidalis, this merely provided a low canopy and low $(\sim 1 \%)$ basal area cover. The plot surfaces were still essentially bare one year after the fire. The reductions, in soil loss particularly, appear from observation to result from the establishment of stability on the soil surface, with flow paths developing some armouring against further erosion.

The rapid recovery of soil loss and, to a lesser extent, overland flow to pre-fire levels are typical of results reported in the literature (Table 2.2). Similar short recovery periods are reported for burned chaparral in California and eucalypt forest in Victoria, Australia (Rowe et al., 1951; Ronan, 1986, respectively). A definite picture emerges of high soil losses immediately following a de-stabilising event. A linear reduction of surface flow would be expected to cause an exponential reduction in soil loss, so it is not surprising that soil loss recovers to pre-fire levels sooner than overland flow. A somewhat different picture emerges from some studies done in California and Oregon where steep and dry (equatorial aspect) slopes with poorly aggregated surface soils may be eroded as much by dry ravel 
(mass flow) in the dry season as by rainfall events (Anderson et al., 1959; Mersereau and Dyrness, 1972). In these situations erosion may continue over a greater period of time, and recovery from disturbance is slower.

Comparable to the high overland flow and soil yields obtained immediately after fire is the large contribution to total yields of single extreme events. Individual large storms following wildfire have been recorded to as causing catastrophic levets of flooding and sedimentation, both in California and Oregon (Colman, 1951; Helvey et al., 1976, respectively) and Australia (Brown, 1972; Leitch et al., 1983; Blong et al., 1982; Atkinson, 1984). Sediments eroded off the slopes in such events may be deposited in the stream channel or lower slopes until subsequent flood events.

\subsubsection{Process of overland flow generation}

Another notable feature of the overland flow plot results in this study was the high variability within and between plots (Table 5.2). The within plot variability is common, and expected because of the high variability of rainstorms and the control these have over yields from plots. The two burned sites differed in soil type, degree of repellency in the soil and in micro-topography. Site B had convex slopes so that the steeper parts of the plot occurred immediately above the collection gutters. The failure of the fuel load treatments to produce consistent effects from the plots is most probably due to inefficient transfer of heat on the double fuel load plots (caused by elevated packing of the fuel), and the insulating effects of moist litter and soil. Plot response was therefore dominated by inherent inter-plot differences. The low overland flow and sediment yields measured elsewhere in Jonkershoek by Versfeld (1981) may be a reflection of the large size of the plots. If yield is produced only from close to the collection point then larger plots will produce proportionately smaller yields. Comparable differences in response between adjacent plots was found by Blong et al. (1982).

Ronan (1986) advances the concept of transient runoff on small plots, analogous to the variable source area concept at the catchment scale. Rain water which cannot infiltrate at a particular point will move downslope until it can infiltrate or percolate in some soil pore which has greater capacity for infiltration. As the capacity of more soil pores is reached under larger storms or higher rainfall intensities, so this surplus water must travel greater distances before infiltrating. Thus during a large rainfall event a progressively larger area would be contributing to the collected overland flow and soil loss on plots. This concept 
would also explain the effect of discontinuous water repellent layers on or near the soil surface. Profiles cut into the soil after rainfalls showed blocks or patches of dry (repellent) soils flanked by wet zones where infiltration had been concentrated.

The effect of the fire in Swartboskloof was to reduce water repellency in the surface soil and increase repellency shallowly below the surface $(10-30 \mathrm{~mm}$; Figure 5.1). Each of the treated plots would have had a complex distribution of surface and below surface patches of water repellent soil, depending on the original distribution of vegetation and litter and the localised effects of the fire. More such impeding layers closer to the collection gutter would have increased the probability of overland flow from a particular plot. An extension of the transient runoff concept also explains the fact that high overland flow and soil loss on steep mid-slopes is not reflected in similar increases at the catchment scale. 'The gentler foot-slopes nearer the streams, other sites of coarse deposits and the largely unburned riparian zones must intercept and absorb much of the overland flow, and with it the transported soil. Steep mid-slopes of the gradients sampled by the plots seldom occur directly above the gauged Swartboskloof stream and are not representative of the catchment as a whole. Overland flow appears to be a powerful process in moving soil and nutrients off mid-slope sites following disturbance.

\subsubsection{Significance of soil losses}

Averaged over a likely burning period for the mountain fynbos ( $>10$ years), the soil losses recorded off burned slopes will be well within the $10 \mathrm{t} \mathrm{ha}^{-1}$ limit used as a guideline for arable land in South Africa (Russell, 1983) though higher than the natural erosion rates measured on undisturbed plots (Smith and Stamey, 1965). Once the burned site is stabilised, which seems to occur largely in the first year, soil losses drop to orders of magnitude less than tolerable levels for cultivated land. This marked difference between actual and tolerable soil losses is, of course, desirable because mountain catchment land cannot be managed, as agricultural lands are, to ameliorate soil loss.

\subsubsection{Stream-flow Generation in the Catchment}

The $16 \%$ increase in annual stream-flow in the two years after fire in Swartboskloof (165 $\mathrm{mm}$ in the first year and $157 \mathrm{~mm}$ in the second) can be explained in terms of reductions in rainfall interception and transpiration following the removal of plant biomass in the catchment. Increases of this magnitude are expected and confirm the numerous findings 
in the south-western Cape and the world regarding the water use of shrub vegetation. After prescribed burns of six-year-old, low fynbos in the Zachariashoek catchments of the south-western Cape, increases of $85 \mathrm{~mm}, 11 \mathrm{~mm}$ and $31 \mathrm{~mm}$ were recorded sequentially in the first three years after the fire in the first cycle, and $68 \mathrm{~mm}$ in the first year of a second cycle (Lindley et al., 1988). Protection of the Langrivier fynbos catchment, across the valley from Swartboskloof, resulted in a net reduction of annual stream-flow of $187 \mathrm{~mm}$ once the shrubland was around 30 years of age ( Van Wyk, 1977). The increases recorded in this study are within the range of responses reported from shrub clearance experiments world-wide (Bosch and Hewlett, 1982).

The tall protea shrubs which dominate vegetation in the lower elevations of Swartboskloof catchment are mainly deep-rooted and regenerate from seed (Higgins et al., 1987). By killing these shrubs, fire would have caused the death of most root mass in the catchment. The persistence of fire-related stream-flow increases in fynbos catchments is postulated to depend on the proportion of seed-regenerating relative to resprouting plants, the so-called seeder:sprouter ratio. The greater the ratio the longer it will take a catchment to return to pre-fire transpiration rates (Bosch et al., 1986). The high proportion of seeders should cause a longer recovery period in Swartboskloof than the roughly two years recorded in Zachariashoek (Lindley et al., 1988) which, being more regularly burned, has a low seeder:sprouter ratio.

The hydrologically most striking of fire effects, namely storm-flows and sedimentation, were virtually unaffected by the Swartboskloof fire. This is an important finding though not altogether unusual. In general it appears that the process of stream-flow generation in the catchment was not altered by the passage of fire. High rainfall inputs were absorbed into the soil mantle at catchment scale and released as base-flow, without large increases in flooding or sedimentation.

Sediment yields from Swartboskloof are greater than the 0.008 tha. ${ }^{-1}$ yielded in the first year after fire from the Zachariashoek catchment in the southwestern Cape which has a purely sandstone geology Nan Wyk, 1982). No flooding and little erosion resulted from the Wheeler Springs Fire in southern California (Colman, 1951). A wildfire in eucalypt forest at Wallaby Creek, Victoria similarly produced no significant sediment concentration increases (Ronan, 1986). Absence of hydrological effects of fire may not have been recorded in other cases simply because of their unremarkabilty. 
The absence of significant fire effects on storm-flows in Swartboskloof may be partly due to the weak pre-fire calibrations (Table 5.5), but it is clear that there was no marked response to fire of the order seen in the nearby Abdolskloof (Rycroft, 1947; Table 2.1) and Bosboukloof (Chapter 4) following late dry season wildfires.

\subsubsection{Synthesis of the Results: The Process of Fire Effects}

Adequate heating can consume organic matter incorporated in the soil, thereby breaking down soil aggregates and increasing erodibility (DeBano et al., 1977; Giovannini and Lucchesi, 1983). This fire effect is important in determining soil loss after fire. In Jonkershoek the soils have a low erodibility so the role of heating may be crucial in controlling the availability of sediments for erosion.

The Bosboukloof catchment is very similar to Swartboskloof in terms of geology, soils, morphology and size. A comparison of other aspects of the catchments gives a basis for explaining their different responses to fire. Bosboukloof is afforested to Pinus radiata over the lower half of the catchment. Soils under pine were found to have a much higher frequency of water repellency than those under fynbos vegetation. Fuel loads in the plantation in Bosboukloof were higher at 1.1 to $15 \mathrm{~kg} \mathrm{~m}^{-2}$ as opposed to 1.2 to $3.5 \mathrm{~kg} \mathrm{~m}^{-2}$ in Swartboskloof. Bosboukloof was burnt in a wildfire with much greater fire intensity, associated with which was the lower fuel and soil moisture levels in Bosboukloof late in a long, hot and dry summer. These conditions would have caused greater heating of soil in Bosboukloof, with resultant increases in soil erodibility and fire-induced water repellency. The Bosboukloof catchment has a well-developed road system and skid paths, which assisted in delivering surface water to the stream channel during rain-storms. In Swartboskloof, by contrast, overland flow off mid-slopes had to cross flatter foot-slopes where it must have entered the soil mantle. Finally, the riparian forest in Bosboukloof was destroyed in the fire while that in Swartboskloof was not. A combination of some or all the above factors could have caused the greater hydrological response in Bosboukloof.

\subsubsection{Synopsis of Important Findings}

The prescribed fire in Swartboskloof had a relatively minor effect on the catchment's hydrological behaviour. Stream-flow from the catchment increased by $16 \%$ in the two years after the fire; giving a total increase of $323 \mathrm{~mm}$. The size of this increase was expected 
from the age and type of vegetation which had occupied the site, and is in agreement with the results from similar studies of shrub vegetation removal or aging elsewhere in the south-western Cape and the world. Quick-flow, storm-flow, peak discharge and storm response ratio did not increase significantly as a result of the fire. In general, it appears that the process by which stream-flow is generated in the catchment was not altered by the passage of fire. High rainfall inputs were absorbed into the soil mantle at catchment scale and released as base-flow, without large increases in flooding or sedimentation.

Large increases in overland flow (from less than $1 \%$ to a mean first year figure of $5.4 \%$ of rainfall) and sediment loss (from 0.013 to a first year mean of $7.5 \mathrm{t} \mathrm{ha} \mathrm{a}^{-1}$ ), on steep midslope plots resulted from burning. These increases are thought to reflect the thorough burning of the plots and a patchwork of water repellency in the soils of the plots. The removal of surface litter and, in places, the consumption of incorporated soil organic matter by the fire, removed surface obstructions to overland flow and resistance to soil movement.

In the second year after fire, overland flow was reduced to a fifth of that measured in the first year, and soil loss was reduced by more than an order of magnitude. Sediment yields on the burned plots, and overland flow on one of the two sites, were still significantly greater in the second year than on an unburned plot. Increases in overland flow led to exponential increases in soil loss. Fire appeared to result in a brief pulse of soil movement on the steep slopes, which should be followed by a period of stability and low soil loss between fires.

The measured overland flow and soil loss on mid-slope plots was independent of the experimental fuel loads, but there were large differences between sites and between plots within sites. The greater overland flow and soil losses recorded at site $B$ are thought to result from the more general occurrence of water repellency in the soils, higher soil erodibility and the convex slope at this site. Differences between adjacent plots at a single site were probably caused by the patchy distribution of repellent soils and high permeability zones, as well as micro-topographic differences between plots.

Soil heating was limited by the high soil wetness levels which resulted from unseasonably high rainfalls in February and early March, 1987. These factors confined the heating of soils during the fire to localised spots, where soil erodibility increased and the fire intensified water repellency in the soils. Increased erodibility and repellency affected water 
movement on steep mid-slope sites but did not translate to marked changes in overall catchment behaviour.

Water repellency in soils was widespread in the surface soil layers of the catchment before the fire. This did not appear to influence water movement on a large scale while there was still abundant surface litter and soil conditions, other than repellency, were conducive to water infiltration. Heating by the fire destroyed much of the water repellent effect in the surface $5-10 \mathrm{~mm}$ of soil, and there was evidence of some fire-induced repellency deeper in the soil profile.

The Swartboskloof study has shown that despite a complete burn under high fuel loads, and accompanying water repellency and some overland flow on mid-slopes, hydrological impacts at the catchment scale need not be substantial. Although not discounting the hypothesis of the role of water repellency in causing serious storm-flow increases and soil erosion, this study indicates the complexity of the issue, requiring that more variables need be taken into account than was indicated by the clearer picture obtained in the Bosboukloof study. In the next chapter the effects of another fire in a fynbos catchment are presented, although in this case it was a wildfire. 


\section{CHAPTER 6}

\section{THE LANGRIVIER STUDY}

Langrivier, the second fynbos catchment, burned in a wildfire in spring, while the catchment was still wet from winter rainfalls. The high fuel loads and high proportion of dead down fuels, nonetheless, caused the catchment to burn with a high intensity. The Langrivier catchment has a large proportion of high rocky crags and has a high relief. Its storm response ratio is high, partly, because of the large area of bare rock or shallow soil, and partly because of a likely under-estimation of catchment rainfall. A similar but less detailed analysis of the effects of the fire to that undertaken in Swartboskloof was done in Langrivier and the results presented in this chapter.

\subsection{STUDIES OF SOIL WETTABILITY}

\subsubsection{Design and Analysis of the Soil Wettability Study}

Twenty random sample points in the lower half of the Langrivier catchment were tested for soil wettability. The tests used were water drop penetration time (WDPT) and critical surface tension (CST), which were combined to give a single repellency index $(\mathrm{RI}=$ WDPT/CST) (DeBano, 1981; Section 3.2.3). On basis of the RI score a sample was classified as wettable, somewhat repellent or repellent. Testing was performed at four depths within each sample profile namely at $0-15 \mathrm{~mm}, 15-50 \mathrm{~mm}, 50-100 \mathrm{~mm}$ and below $100 \mathrm{~mm}$. The occurrence of repellency in the Langrivier soils was compared to that found in the larger sample of soils (75 profiles) in the Swartboskloof catchment prior to burning. The frequency of repellent soils in Swartboskloof before fire was used as a control - a naturally occurring level of repellent soil which was independent of fire. The significance of differences between the expected frequency (Swartboskloof) and the observed frequency (Langrivier) was tested using a Chi-squared test for enumeration data (Steel and Torrie, 1960). 


\subsubsection{Results of the Soil Wettability Study}

The pattern of occurrence of water repellent soils in Langrivier after the wildfire is illustrated in Figure 6.1. It can be seen that the greatest frequency of repellency was in the surface layer ( $40 \%$ of the samples in the top $15 \mathrm{~mm}$ were repellent). In the next depth layer (15 $50 \mathrm{~mm}$ ) only $30 \%$ of the samples were repellent, and below this there was little repellency. The Chi-squared test showed that, except for the repellent soils in the surface layer, which were no less frequent, the soils in Langrivier were significantly less repellent than those in Swartboskloof before burning.

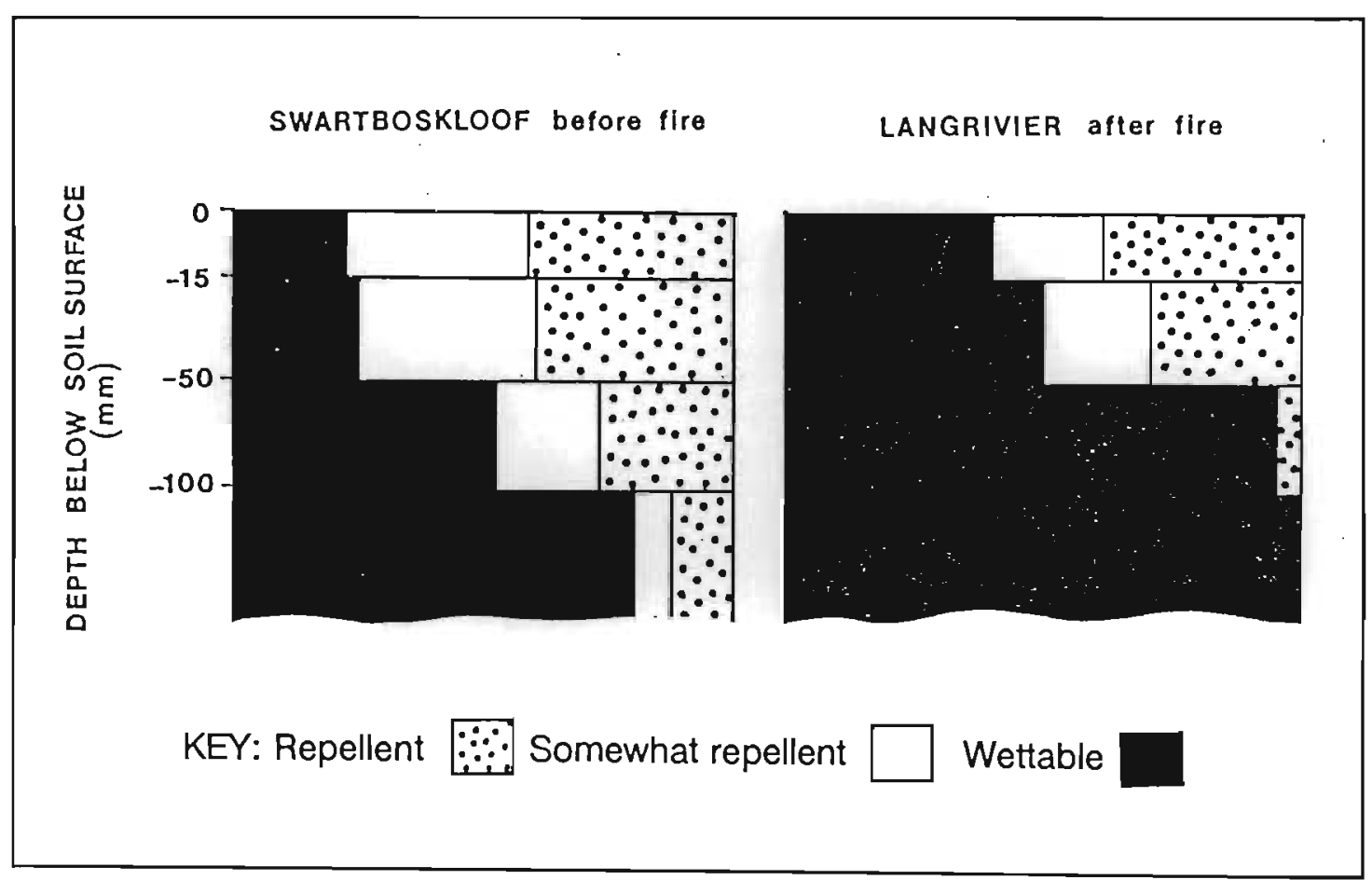

Figure 6.1 The proportion of 20 soil sample profiles in three soil wettability classes in Langrivier catchment contrasted against 75 unburned profiles in Swartboskloof.

Langrivier exhibited the same pattern of repellency as was observed in Swartboskloof: soils near the surface, in close contact with plant residues, were more likely to be repellent, while below $50 \mathrm{~mm}$ depth the repellency phenomenon was rare. At no depth were repellent soils close to forming a continuous layer in the soil profile.

The lower frequency of repellency recorded in Langrivier may be due to the higher soil wetness at the time of the survey. It has been shown that the same soil will exhibit a higher repellency when it is dry than when it is moist (DeBano et al., 1967; Gilmour, 1968). At the time the burned sōils in Langrivier were surveyed (November, 1987) they were 
relatively moist due to the winter rains. Thus the observed pattern, frequency and severity of water repellency in Langrivier is not considered to be meaningfully different from that under unburned conditions.

\subsection{STUDIES AT THE PLOT SCALE}

\subsection{1 . Layout of Surface Runoff Plots}

To test the hypothesis that the Langrivier fire had caused a significant reduction in infiltrability of soils, three overland flow plots were laid out in Langrivier. Two plots (Langrivier 1 and 2) were sited north of the gauging weir on a slope of $53 \%\left(28^{\circ}\right)$ and were operating by the end of October 1987. A further plot (Langrivier 3) was established by the end of December of that year on a site south-east of the weir, with a slope of $59 \%\left(30.5^{\circ}\right)$ and soils which appeared to be somewhat more water repellent than at the first site. A single control plot was established by the end of December (1987) in the mature (12 year old) fynbos of Sosyskloof (see Figure 3.1) at a slope of 53\%. The Langrivier plot sites were chosen to be accessible from the road, have reasonably steep slopes, and be near the stream so that any overland flow and soil erosion recorded on the plots might be reflected in the monitored stream-flow from the catchment.

These rectangular plots were identical to those used in Swartboskloof (Section 5.2.1). The volume of water from overland flow and the amount of sediment collected was measured after each major rain event. Rainfall depth was measured by rain-gauges at each plot site. Maximum 30-minute and 60-minute rainfall intensities were determined from the charts of the Casella recording rain-gauge at the nearby Swartboskloof weather station. The first two rainfall events after the fire, in November and December, were not recorded on the Langrivier 3 and Sosyskloof plots as these plots were not yet in operation.

Responses from an average of 52 storms per plot were measured and analysed. The dependent variables were overland flow (depth) and the soil loss. Independent variables were the rainfall amount and intensity, and for soil loss included the additional term of overland flow. The data were analysed by a multiple regression method, in the same way as the plot data in Swartboskloof (see Section 5.2.1). 


\subsubsection{Results of the Overland Flow Plots Study}

The actual depths of overland flow and soil loss are low in absolute terms, but were significantly greater than on the control plot in both years (Table 6.1 and Figure 6.2). Overland flow on the three burned plots averaged 2.2 and $2.1 \%$ of rainfall in the first and second post-fire years respectively. Soil loss on the plots averaged approximately 1.15 and $1.67 \mathrm{t} \mathrm{ha}^{-1}$ in the first and second post-fire years respectively. The seasonality of the runoff and erosion from the plots, and the change in yields in the second year are illustrated in Figure 6.2. There was significantly $(a<0.01)$ more overland flow generated on the burned Langrivier plots than on the Sosyskloof control plot, though the mean of sediment yields on the single plot (Langrivier 3) was not statistically different from those on the control plot (Table 6.1). There was no significant difference between the means of overland flow on the plots within Langrivier, though sediment yields from the single burnt plot (Langrivier 3) were significantly lower than those of the pair of plots (Langrivier 1 and 2).

Langrivier 3 which was slightly steeper and appeared to have more water repellent soil than the other plots produced the least overland flow and soil loss, though not statistically less, of the three burned plots. This plot also showed the same exponential decline in yields in the second post-fire year as recorded in Swartboskloof. On the other plots (Langrivier 1 and 2) yields were higher in the second year, though not statistically different from the first year. Most of the second year increase can be attributed to a particularly large storm in August 1988 (Figure 6.2). The results illustrate the high individuality of plots, which accounts for a significant part of the variation in overland flow and sediment yields (Table 6.2).

Multiple regression analysis shows that separate models (significant at $a<0.05$ ) can be developed to best explain the response of each of the four plots to rainfall, antecedent wetness and rainfall intensity (Table 6.2). In the second year the single plot (Langrivier 3 ) is marginally different from the control plot. The higher yielding plots (Langrivier 1 and 2) were more responsive to rainfall intensity (i.e. rainfall intensity was a more useful predictor on these plots). 
Table 6.1

Mean overland flow and soil loss per storm and total annual soil loss per plot in the Langrivier study in the first and second post-fire years. Where the value represents a mean its standard deviation is given in brackets.

\begin{tabular}{|c|c|c|c|c|}
\hline Plot & $\begin{array}{l}\text { Overland flow } \\
(\mathrm{mm})\end{array}$ & $\begin{array}{l}\text { Overland flow as } \\
\% \text { of rain }\end{array}$ & $\begin{array}{l}\text { Sediment loss } \\
\left(\mathrm{kg} 100 \mathrm{~mm}^{-1}\right)\end{array}$ & $\begin{array}{l}\text { Sediment yield } \\
\left(t \mathrm{ha}^{-1} \mathrm{a}^{-1}\right)\end{array}$ \\
\hline \multicolumn{5}{|c|}{ Sosyskioof Control } \\
\hline Year 1 & $0.49(0.95)$ & $0.81(0.94)$ & $0.005(0.014)$ & 0.0132 \\
\hline Year 2 & $0.37(0.66)$ & $0.66(0.79)$ & $0.0007(0.0009)$ & 0.0016 \\
\hline \multicolumn{5}{|l|}{ Langrivier 1} \\
\hline Year 1 & $1.20(1.34)$ & $2.33(2.12)$ & $0.70(1.24)$ & 1.80 \\
\hline Year 2 & $1.20(1.86)$ & $2.95(2.50)$ & $1.32(2.95)$ & 3.35 \\
\hline \multicolumn{5}{|l|}{ Langrivier 2} \\
\hline Year 1 & $1.08(1.21)$ & $2.10(1.89)$ & $0.65(1.58)$ & 1.54 \\
\hline Year 2 & $1.48(1.74)$ & $2.24(2.12)$ & $0.64(1.31)$ & 1.63 \\
\hline \multicolumn{5}{|l|}{ Langrivier 3} \\
\hline Year 1 & $1.05(0.75)$ & $2.10(0.68)$ & $0.04(0.06)$ & 0.10 \\
\hline Year 2 & $0.56(0.55)$ & $1.00(0.70)$ & $0.01(0.03)$ & 0.01 \\
\hline
\end{tabular}

Table 6.2 Best regression models for the explanation of overland flow and soil loss from small plots in Langrivier and the unburnt control plot in Sosyskloof.

\begin{tabular}{lcccl}
\hline \multicolumn{2}{l}{ Dependent variable } & Error df & Adjusted $\mathbf{R}^{2}$ & $\begin{array}{l}\text { Significant }(a<0.05) \\
\text { independent variables }\end{array}$ \\
\hline First year & Surface runoff & 69 & 0.66 & $\begin{array}{l}\text { Rainfall, antecedent wetness, } \\
\text { plot }\end{array}$ \\
& Soil loss & 68 & 0.49 & $\begin{array}{l}\text { Rainfall, antecedent wetness, } \\
\text { plot }\end{array}$ \\
Second year & Surface runoff & 82 & 0.68 & $\begin{array}{l}\text { Rainfall, plot, rainfall intensity, } \\
\text { antecedent wetness } \\
\end{array}$ \\
& Soil loss & 82 & 0.81 & $\begin{array}{l}\text { Rainfall, plot, rainfall intensity, } \\
\text { antecedent wetness }\end{array}$ \\
\hline
\end{tabular}

Statistically, the characteristics of each plot are clearly important and the variation between plots accounts for a major share of variation in the dependent variables. Within each plot, most variation in overland flow and sediment yield was explained by the depth of the rainfall and antecedent wetness, with rainfall intensity, while a significant predictor term, adding relatively little to the variances explained. 


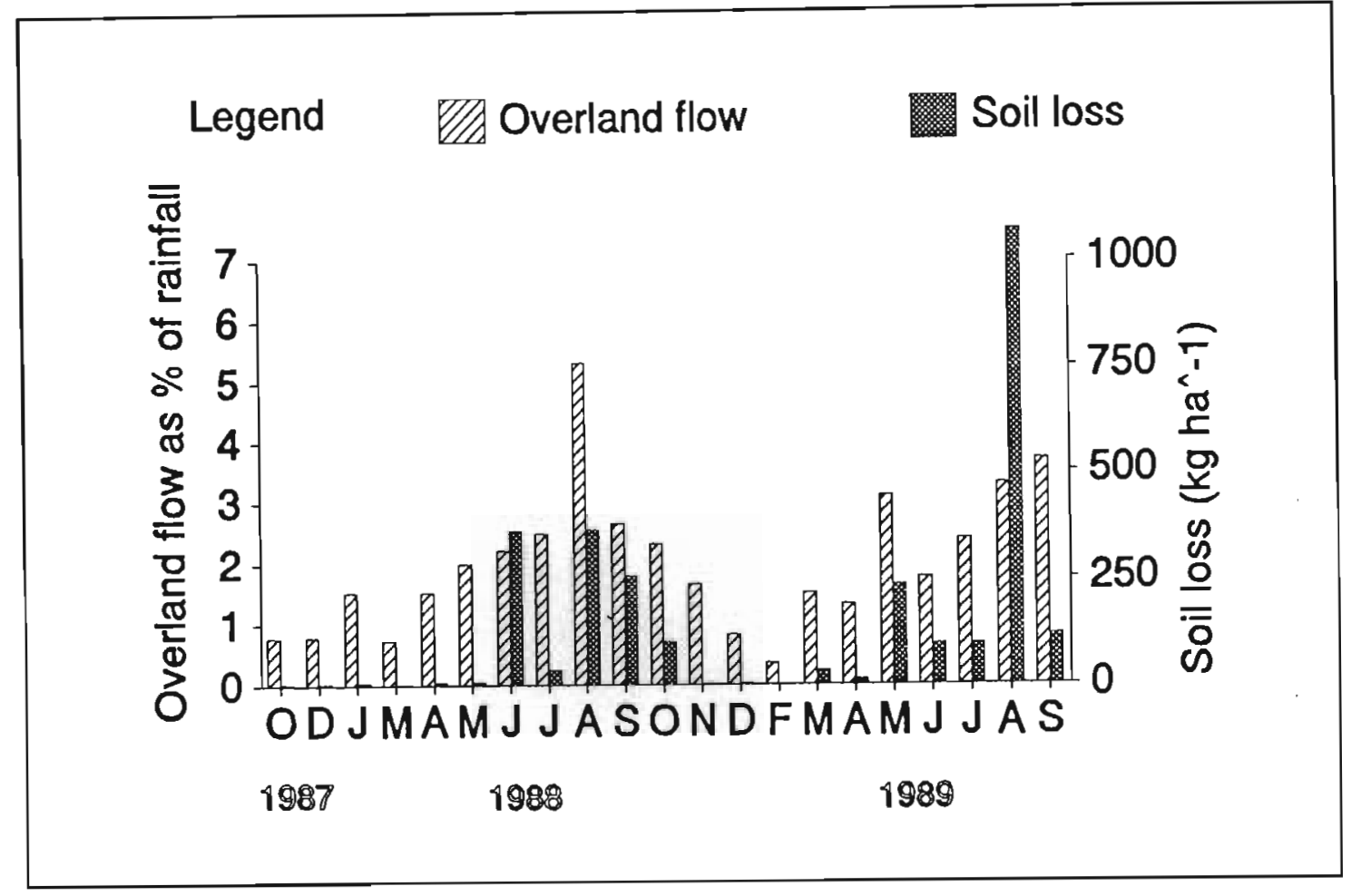

Figure 6.2 Means of overland flow depth per storm event and mean monthly soil loss from three plots in the burned Langrivier catchment.

\subsection{STUDIES AT THE CATCHMENT SCALE}

\subsubsection{Stream-flow}

At catchment scale none of the measured storm-flow variables changed significantly ( $a<$ 0.05) as a result of the fire (Table 6.3). Because the Langrivier catchment has a fairly singular behaviour within the Jonkershoek network of catchments it was not possible to develop tight calibration equations for the storm-flow variables. The highest adjusted $R^{2}$ for any storm-flow regression model being 0.91 for storm-flow volume (Table 6.3). As was the case in Swartboskloof, therefore, only large storm-flow changes could have been shown by the paired catchment method. It is clear from the regression analysis results, however, that the wildfire in Langrivier caused no sharp change in the hydrological response of the catchment (Table 6.4), and any change was in fact smaller than that seen in Swartboskloof. 
Table 6.3

Significant $(a<0.05)$ predictor terms in the multiple regression models developed for the pre-fire and full periods of storm-flow data in the Langrivier catchment. The presence of the fire dummy variable $(F)$ in the post-fire models indicates a significant effect of fire.

\begin{tabular}{|c|c|c|c|c|c|c|}
\hline \multirow[b]{2}{*}{$\begin{array}{l}\text { Dependent } \\
\text { variable }\end{array}$} & \multicolumn{3}{|c|}{ Calibration period } & \multicolumn{3}{|c|}{ Full measurement period } \\
\hline & $\begin{array}{l}\text { Significant } \\
\text { predictor } \\
\text { terms }\end{array}$ & $\begin{array}{l}\text { Error } \\
\text { d.f. }\end{array}$ & Adjusted $\mathbf{R}^{2}$ & $\begin{array}{l}\text { Significant } \\
\text { predictor terms }\end{array}$ & $\begin{array}{l}\text { Error } \\
\text { d.f. }\end{array}$ & Adjusted $\mathbf{R}^{2}$ \\
\hline $\begin{array}{l}\text { Weekly stream- } \\
\text { flow }\end{array}$ & C, R, API & 232 & 0.98 & $C, S, R, A P I, F$ & 332 & 0.98 \\
\hline $\begin{array}{l}\text { Quick-flow } \\
\text { volume }\end{array}$ & $C, D$ & 61 & 0.84 & $C, D$ & 107 & 0.88 \\
\hline Peak discharge & $C, D, Q_{i}$ & 60 & 0.82 & C, D, Q & 107 & 0.78 \\
\hline Response ratio & $C, D$ & 61 & 0.83 & C, D & 108 & 0.76 \\
\hline $\begin{array}{l}\text { Storm-flow } \\
\text { volume }\end{array}$ & $C, Q_{1}, D$ & 60 & 0.91 & $C, Q_{11} D$ & 107 & 0.88 \\
\hline
\end{tabular}

$\begin{array}{lll}\text { Key: } & \mathrm{R} & = \\ \mathrm{C} & = & \text { weekly rainfall } \\ \mathrm{S}, \mathrm{F} & = & \text { the corresponding control catchment variable } \\ \mathrm{D} & = & \text { storm duration } \\ \mathrm{Q}_{\mathrm{i}} & = & \text { initial discharge } \\ \mathrm{API} & = & \text { antecedent precipitation index }\end{array}$

In Langrivier the total water yield increased by $119 \mathrm{~mm}(9.4 \%$ more than the expected 1265 $\mathrm{mm}$ ) in the first year after fire (Table 6.4), but stream-flow had returned to pre-fire levels by the end of the second full year (Figure 6.3). The first-year increase is ascribed to reductions in rainfall interception and transpiration following the removal of vegetation. Increases of this magnitude are expected and confirm the findings in the south-western Cape and elsewhere regarding water use by shrub vegetation (Bosch and Hewlett, 1982; Lindley et al., 1988), though Van der Zel and Kruger (1970) and later Van Wyk (1977) attributed much greater water use $(-400 \mathrm{~mm}$ and $220 \mathrm{~mm}$, respectively) to the tall fynbos of Langrivier in a mature state. Bosch et al. (1986) proposed a model for predicting increases in streamflow following fire in fynbos, based on pre-fire biomass and the expected rate of recovery of the vegetation. The model predicts increases in stream-flow of around 120 and $93 \mathrm{~mm}$ in the first and second years after fire respectively. 
Table 6.4 Changes in stream-flow variables as a result of the wildfire in Langrivier catchment. Percentage change figures in brackets are not statistically significant $(a<0.05)$.

\begin{tabular}{|c|c|c|c|c|c|}
\hline \multirow{2}{*}{$\begin{array}{l}\text { Stream-flow } \\
\text { variables }\end{array}$} & \multicolumn{2}{|c|}{$\begin{array}{l}\text { Recorded pre- } \\
\text { fire }\end{array}$} & \multicolumn{2}{|c|}{$\begin{array}{l}\text { Recorded in } \\
\text { first post-fire } \\
\text { year }\end{array}$} & \multirow[t]{2}{*}{$\begin{array}{l}\text { Change over } \\
\text { expected value }\end{array}$} \\
\hline & mean & $n$ & mean & $n$ & \\
\hline $\begin{array}{l}\text { Weekly stream-flow } \\
(\mathrm{mm})\end{array}$ & 34.5 & 132 & 25.2 & 52 & $9.4 \%$ increase \\
\hline $\begin{array}{l}\text { Quick-flow volume } \\
(\mathrm{mm})\end{array}$ & 24.5 & 65 & 20.6 & 21 & (3.8\% increase) \\
\hline $\begin{array}{l}\text { Peak discharge } \\
\left(\mathrm{mm} \text { day }{ }^{-1}\right)\end{array}$ & 34.7 & 65 & 42.2 & 21 & ( $8.4 \%$ increase) \\
\hline Response ratio (\%) & 38.6 & 65 & 36.0 & 20 & (11\% increase) \\
\hline Storm-flow (mm) & 36.6 & 65 & 30.3 & 21 & (3.8\% increase) \\
\hline
\end{tabular}

$\dagger$ Change is calculated as $\{($ Observed - Predicted $) /$ Predicted $\} \times 100 \%$

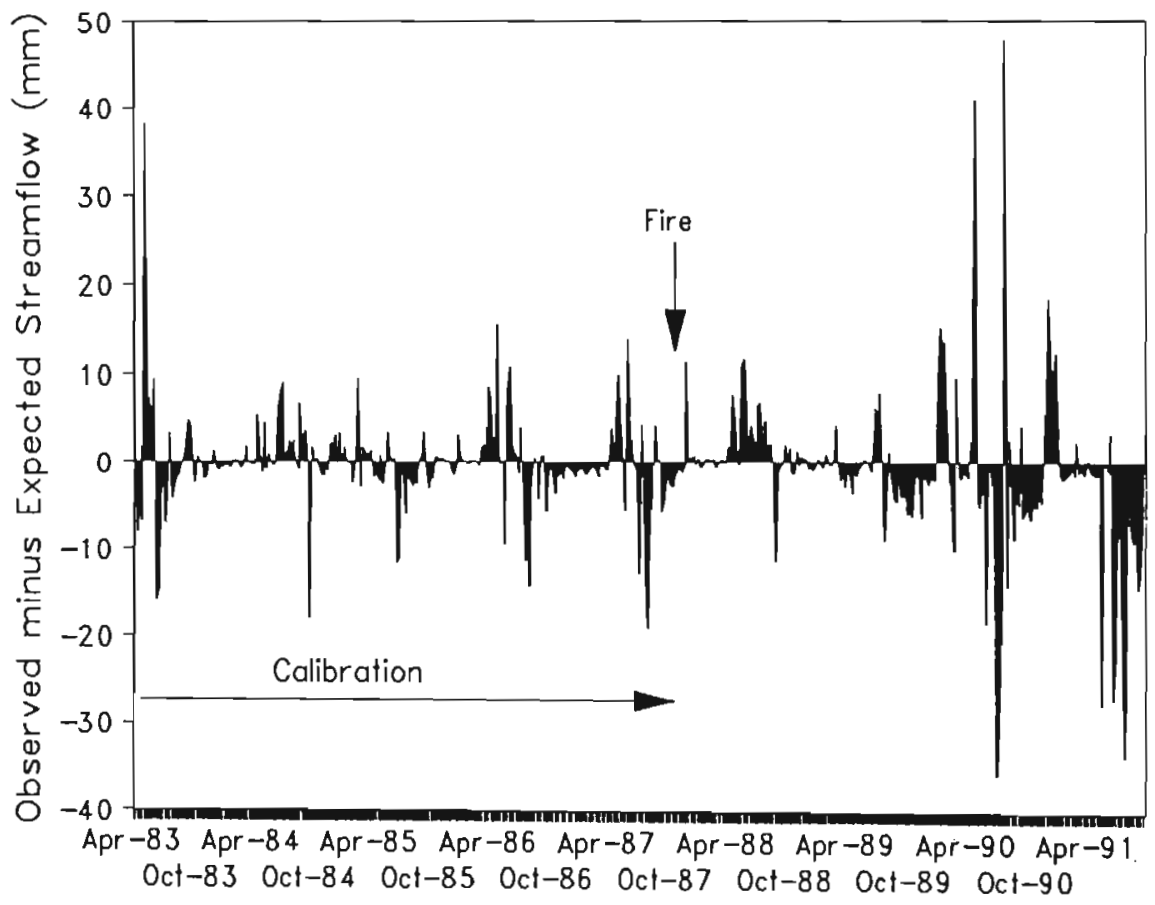

Figure 6.3 Time plot of the deviations of weekly stream-flow volume about the fitted calibration model which had an adjusted $R^{2}=0.98$. 
The absence of a stream-flow increase in the second post-fire year is surprising. It could be ascribed to two causes:

(i) a rapid re-growth of vegetation in the Langrivier catchment, or

(ii) a large error or combination of errors which cover up the expected response.

The first cause is unexpected as the catchment is dominated by seed-regenerating fynbos plants, which would have taken longer than two years to develop a large transpiring leaf area. The second possible cause (that of a large random error) is fairly unlikely because the large sample size (52 weekly totals). Analysis of further post-fire stream-flow showed a progressive downward trend in water yield after the initial fire related increase (Figure 6.3). The most likely explanation therefore is that the very old fynbos (42 years) which burnt was at such an advanced state of senescence that its water use had declined as it aged beyond thirty years, despite the high biomass on the site. According to this hypothesis, therefore, stream-flow would have been at a high level at the time of the fire, from which only the sharp increase in the next 18 months was detectable. Subsequent declines in stream-flow associated with the re-growth of vegetation rapidly negated the water savings resulting from the removal of the old vegetation.

\subsubsection{Sediment Yields}

A minor increase in sediment loss during storms was recorded in the first six months after the fire in Langrivier Nan Wyk and Lesch, 1989) but annual soil loss (0.148 $\left.\mathrm{tha}^{-1} \mathrm{a}^{-1}\right)$ was nonetheless below that in the previous year. Total sediment yield is strongly dominated by sediment yield during storm-flows (Nan Wyk and Lesch, 1989). The lack of notable increases in sediment yields after the fire, these being dependent on available energy in the stream-flow, is therefore thought to be linked to the absence of a storm-flow response to fire.

\subsection{DISCUSSION AND SYNTHESIS}

\subsubsection{Soil Wettability}

The age of the vegetation, and hence time of contact between litter and soil, has been positively related to the degree of repellency shown by the soil (Teramura, 1980). During the long period of fire exclusion from the Langrivier catchment, the surface soils could have 
developed water repellency through prolonged contact with plant litter, similar to that recorded in the unburnt Swartboskloof catchment. In these circumstances fire can intensify water repellency in the soil or remove hydrophobic effects in the surface soils as outlined in Section 2.1.3.3.

Over much of the Langrivier catchment, however, the occurrence of repellency does not appear to have been affected by the passage of the fire. This is probably due to inadequate heating of soils during the Langrivier fire. Fuel loads were high and the consumption of ground fuels almost complete, but the surface litter layer was only partially consumed over a large part of the catchment. Soil and fuel moisture contents were probably too high at the end of the wet season to allow soil temperatures in excess of $100^{\circ} \mathrm{C}$ to develop. As shown in Section 2.1.3.1, the effect of water in soil is to greatly increase its heat capacity and thermal conductivity (Hillel, 1980), and soil temperatures will not exceed $100^{\circ} \mathrm{C}$ until all water has been driven off (Scotter, 1970).

\subsubsection{Overland Flow and Soil Erosion}

In terms of overland flow and sediment yield on hillslopes the effects of the fire in Langrivier are probably within acceptable ecological limits. It is difficult to determine what rate of soil erosion is acceptable, but considering the steepness of the slopes (53\%) on which the plots were located, the measured sediment yields from other land-uses, and the infrequency of fire, a soil loss on these slopes of less than $1 \mathrm{t} \mathrm{ha}^{-1}$ cannot be considered excessive.

It can be expected that with the rapid recovery of a vegetation cover in the catchment, most soils which had been eroded and re-deposited will be held in place until another major fire. In the longer term downward movement of soil may continue in this way until it either reaches the stream or is deposited on gentler slopes, on which overland flow does not occur.

Although the fire in Langrivier consumed much of the plant litter and thus exposed the soil surface, field observations showed that the heat of the fire was seldom great enough to cause combustion of the organic matter which was incorporated into the soil and partly responsible for soil aggregation. This meant that the soil particles were not, generally, in a detached form and available to be transported. Soil particles therefore required to be 
detached first by overland flow before being transported downslope, which necessitated additional energy.

The mean overland flow of $2.5 \%$ of rainfall measured on the Langrivier plots and the $0.6 \%$ from the unburnt control plot are very much higher than values recorded by Versfeld (1981). Part of this effect is due to the steeper slopes of the Langrivier plots, but the discontinuous water repellency in the surface soils was probably necessary before any overland flow would occur. The Sosyskloof control site probably yielded less overland flow because it had less repellency, because of its shorter period of exposure to fynbos litter, and/or because of the surface detention and retention storage capacity provided by litter. In places where steep slopes lie directly above the stream channel such overland flow as was measured, could be expected to become part of the storm-flow. Usually, however, the slopes are gentler towards the stream and any surface water will have a further opportunity to infiltrate into the soil profile.

\subsubsection{Synthesis of the Results: The Process of Fire Effects}

In the Langrivier catchment, as in Swartboskloof, fire did not appear to have changed the mode of stream-flow generation, despite the greatly increased proportion of rainfall which moved overland on mid-slopes relative to an unburned site. The conditions which caused overland flow (bare soil surface, water repellency and slope) were heterogeneous enough to allow most surface runoff to infiltrate before reaching a stream channel. Without surface runoff reaching the stream channel the soil eroded off the mid-slopes must have been deposited on lower elevation and lower gradient slopes in the catchment. Consequently, the effect of fire on hydrology was restricted to a small, immediate increase in total streamflow, resulting from reduced transpiration and interception losses. By the third year after the fire total flow was reduced below pre-fire levels due to the rapid and vigorous regrowth of the shrubby vegetation. 
The study of the effects of fire in the Langrivier catchment has confirmed the results of the Swartboskloof study. Fire in fynbos under circumstances which do not produce extreme soil heating or total combustion of all ground cover had a minor impact on the hydrology of the catchments. In the next chapter the results of a study of wildfire effects in another partially afforested catchment are presented, showing effects which are similar to those recorded for the Bosboukloof catchment (Chapter 4). 


\section{CHAPTER 7}

\section{THE NTABAMHLOPE STUDY}

In this chapter the effects of another wildfire in a partially afforested catchment are discussed. In this case the trees that had been planted were Eucalyptus fastigata and the catchment was in a distinctly different climatic region to the other catchments studied. The Ntabamhlope catchments, described in full in Chapter 3, are in the summer-rainfall area of South Africa with a climate closer in character to that of the major timber-producing areas of South Africa. With rainfall dominated by high-intensity convectional storms the Ntabamhlope catchments are more responsive than the Jonkershoek catchments. For this study the data were supplied by the Department of Agricultural Engineering of the University of Natal, and consequently the range of stream-flow variables that have been analysed is somewhat different and larger from those used in the studies reported on in the previous three chapters. Data from only the first 10 post-fire months have been analysed: after this time the burried plantation was cleared and the whole site ripped and ploughed in preparation for re-planting.

\subsection{STUDY OF SOIL WETTABILITY}

No formal study of soil wettability in the burned catchment was undertaken for reasons of logistic and time constraints. However, field inspection of the soils in the burned catchment using the water drop penetration time and critical surface tension tests indicated:

(i) that in the eucalypt plantation, there was a high frequency of water repellency shallowly below the surface, and more so in the lines where slash had been piled. The observed pattern of wettable surface soils underlain by a repellent layer, matched that recorded in Bosboukloof (Section 4.1.2).

(ii) The grassland soils which had burned were, by comparison to the eucalypt soils, readily wettable.

(iii) As was observed at Bosboukloof, soils in nearby unburned eucalypt plantation at Ntabamhlope were repellent whether burned or not. The shallowly wettable surface 
layer of soil and the absence of surface litter were the distinguishing features of the burned sites.

\subsection{STUDIES AT THE PLOT SCALE}

\subsubsection{Soil Erosion from Small Plots}

In order to measure soil loss from mid-slopes following the fire, three overland flow plots of standard size $(3 \times 22 \mathrm{~m})$ were laid out lengthwise down a slope of $26 \%$ in the burned eucalypt plantation (Figure 3.2) to measure the mass of soil loss. Two plots were established on the line of two adjacent, burned slash piles where the fuel load had been concentrated and one plot placed between them.

As the research site is remote, and it would not be possible to visit the plots more often than once a fortnight, a collection drum was devised which would retain only the waterborne sediment. Below each plot a section of concrete pipe, roughly $1.2 \mathrm{~m}$ long and with a diameter of $0.6 \mathrm{~m}$, was placed on a wooden pallet. Between the open bottom of the pipe and the pallet was a filter made of a double sheet of "bidum" geotextile supported by a flat piece of expanded sheet-metal. Water draining off a plot was collected in a gutter and led into the collection drum where the sediment was filtered out.

The plots were checked at least once a month during the rainy season following the fire, and the mass of soil loss was determined by measuring the volume and bulk density of sediment trapped in the collection drums. A fourth plot, with slightly steeper slope (40\%), was established as a control in a nearby unburned eucalypt plantation to measure the depth of overland flow and its associated sediment load. Because servicing of the site was infrequent and the rainstorms sporadic, the data were not adequate to allow a detailed analysis of the yield response of the plots.

The mean soil loss from the two "slash pile" plots $\left(75 \mathrm{t} \mathrm{ha}^{-1}\right)$ was $64 \%$ higher than the 46 $\mathrm{t} \mathrm{ha} \mathrm{a}^{-1}$ measured from the less severely burned "between-pile" plot. Based on the estimate that slash piles covered a fifth of the plantation area, then a weighted mean soil loss would be around $52 \mathrm{t} \mathrm{ha}^{-1}$. Estimated losses from the undisturbed eucalypt control plot were more than two orders of magnitude lower $\left(0.1 \mathrm{t} \mathrm{ha}^{-1}\right)$ than those off the burned plots, despite steeper slopes. 


\subsection{STUDIES AT THE CATCHMENT SCALE}

\subsubsection{Stream-flow}

Although the actual means of some variables were lower in the generally drier (Section 8.3.2.1) post-fire period, as shown in Table 7.1, relative to their expected size (predicted in terms of the calibration relationships) they had in fact increased markedly (last column in Table 7.1). In the 10 months following the fire the weekly stream-flow yield of the fireaffected catchment $(\mathrm{V} 1 \mathrm{H} 020)$ showed a small $(6 \%)$ but significant decrease over that predicted by the calibration regression model (Tables 7.1 and 7.2). Before the fire the best regression model to fit the weekly stream-flow data contained the upper (control) catchment (V1H028) stream-flow and an antecedent precipitation index (API) as the only significant predictors. After the fire API was supplanted by weekly rainfall as the secondary predictor (Table 7.2). Stream-flow thus became more directly dependent on rainfall as a result of burning.

Table 7.1 The mean pre-fire and post-fire values of the stream-flow and storm-flow variables, and the estimated change as a result of the passage of fire in catchment V1H020 at Ntabamhlope.

\begin{tabular}{|c|c|c|c|c|c|}
\hline $\begin{array}{l}\text { Stream-flow } \\
\text { variables }\end{array}$ & $\begin{array}{l}\text { Recorded pre-fire } \\
\text { mean }\end{array}$ & n & $\begin{array}{l}\text { Recorded post-fire } \\
\text { mean }\end{array}$ & $n$ & $\begin{array}{l}\% \text { Change over } \\
\text { expected value }\end{array}$ \\
\hline Weekly stream-flow (mm) & 5.09 & 84 & 2.10 & 41 & $6 \%$ decrease \\
\hline Weekly base-flow (mm) & 3.47 & 137 & 0.92 & 71 & $48 \%$ decrease \\
\hline Quick-flow volume (mm) & 4.69 & 31 & 2.08 & 13 & $92 \%$ increase \\
\hline Peak discharge $\left(\mathrm{m}^{3} \mathrm{~s}^{-1}\right)$ & 0.66 & 31 & 1.21 & 13 & $1100 \%$ increase \\
\hline Response ratio (\%) & 10.31 & 31 & 6.53 & 13 & $319 \%$ increase \\
\hline Storm duration (min) & 1464 & 28 & 690 & 13 & $12 \%$ increase \\
\hline Time to peak (min) & 193 & 23 & 54.9 & 10 & $53 \%$ decrease \\
\hline $\begin{array}{l}\text { Ratio of recession } \\
\text { limb to rising limb } \\
\text { storm-flow }\end{array}$ & 3.38 & 23 & 22.3 & 10 & $1206 \%$ increase \\
\hline
\end{tabular}

The base-flow component of the total flow (total flow minus storm-flow volume) was found to have decreased significantly after the fire by $45 \mathrm{~mm} \mathrm{a}^{-1}$ (Tables 7.1 and 7.2). Given the relatively dry period after the fire this represented a large (48\%) decrease on expected base-flow. 

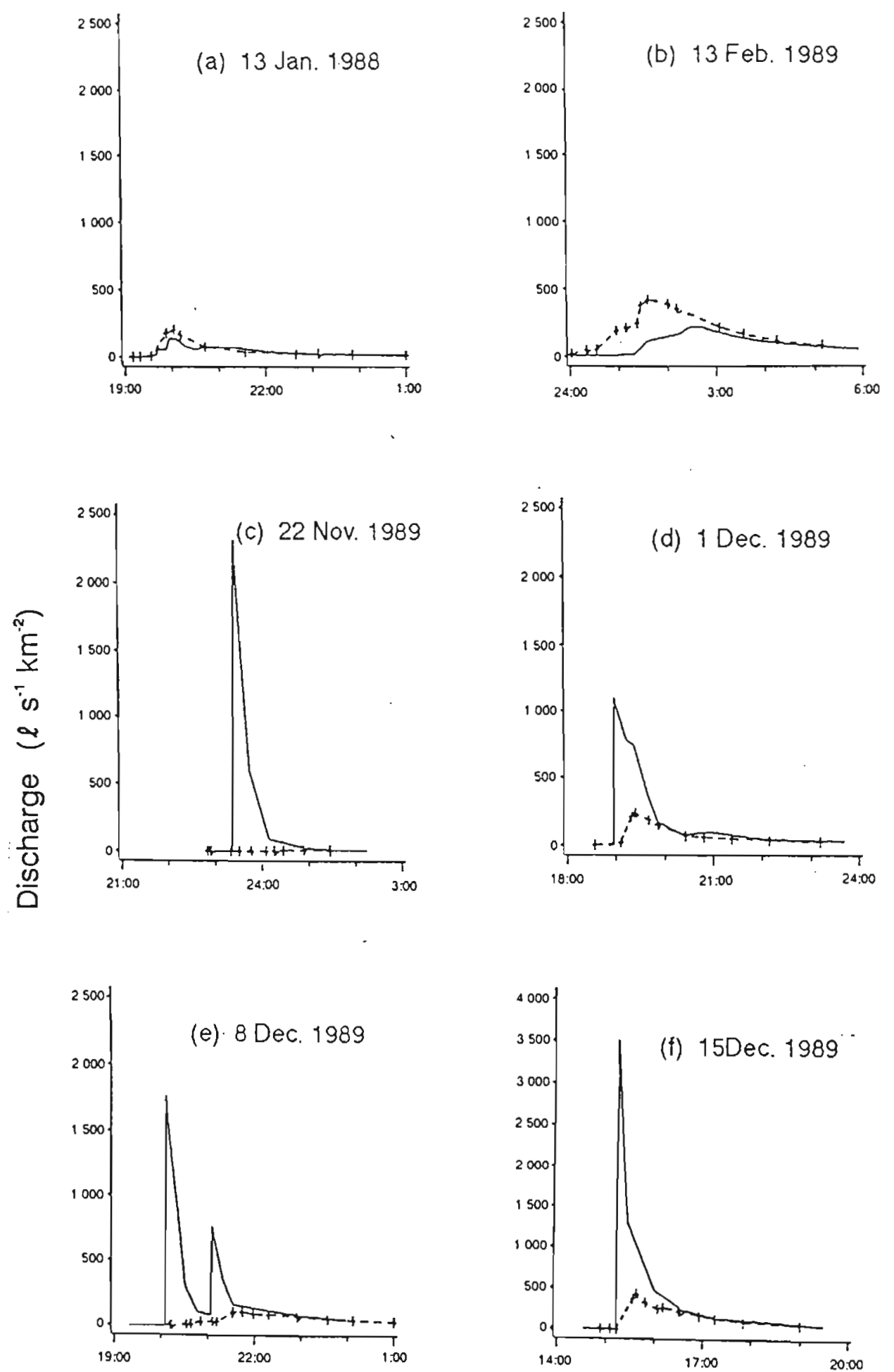

\section{Time of day}

Figure 7.1 Sample hydrographs from Ntabamhlope catchments $V_{1} \mathrm{H} 020$ (solid line) and $\mathrm{V} 1 \mathrm{H} 028(-+-)$ illustrating the change in the relationship between the catchments after the August 1989 fire \{plots (c) - (f) \}. 
The results of the storm-flow analysis show that after the fire rainfall inputs were reaching the stream very quickly, causing a rapid rise in stream levels. It is postulated that this quick delivery of water to the stream channel was by means of overland flow (surface runoff). If the whole of the post-fire increase in storm response is attributed to the plantation area, then after the fire quick-flow volumes from this part of the catchment represented up to $42 \%$ of the rainfall inputs. Given the site conditions and the shortened time-to-rise of the hydrograph (Figure 7.1, Table 7.1), it is clear that a large proportion of this contribution must have been overland flow. Water repellent soils in the burned catchment are thought to have played a part in generating overland flow from the burned areas.

\subsubsection{Sediment Yields}

In the 10 months after the fire, which included the first post-fire wet season, suspended sediment yield from the entire catchment was estimated as $182 \mathrm{t}$. Spread over the entire catchment this is an average of only $1.35 \mathrm{t} \mathrm{ha}^{-1}$, although if all this sediment is assumed to have derived from the burned plantation portion of the catchment, an assumption which agrees with observation ${ }^{1}$, then the loss averages $5.22 \mathrm{t} \mathrm{ha}^{-1}$.

Suspended sediment yields during storms dominated the total suspended yield $(88 \%$ of total). Suspended sediment concentrations tended to peak somewhat ahead of peak discharge (Figure 7.2). This effect of sediment exhaustion is not unusual (Finlayson and Wong, 1982) and has been recorded in other catchments in this network (Schmidt and Schulze, 1989). It indicates that the supply of sediment and dissolved substances, rather than the energy for transport, is the limiting factor. The role of supply in erosion is also illustrated by the higher soil losses off the more severely burned slash pile plots that had a higher soil erodibility (Section 7.2.1). A dilution of electrolytes in the stream water would normally be expected during storm-flows, yet in this catchment electrical conductivity (EC) increased with discharge in phase with suspended sediment. It is postulated that the coincidence of the suspended sediment and EC peaks was caused by the erosion of soils

The sediment yield from $\mathrm{V}_{1} \mathrm{H} 020$ had previously been monitored during 1985 - 1987 and was negligible (RE Schulze, 1991, personal communication; Prof Schulze is leader of the Ntabamhlope research catchments project, Department of Agricultural Engineering, University of Natal, Pietermaritzburg). 
and ash in overland flow, and that the ash, in particular, contained readily soluble compounds which increased EC during storms.

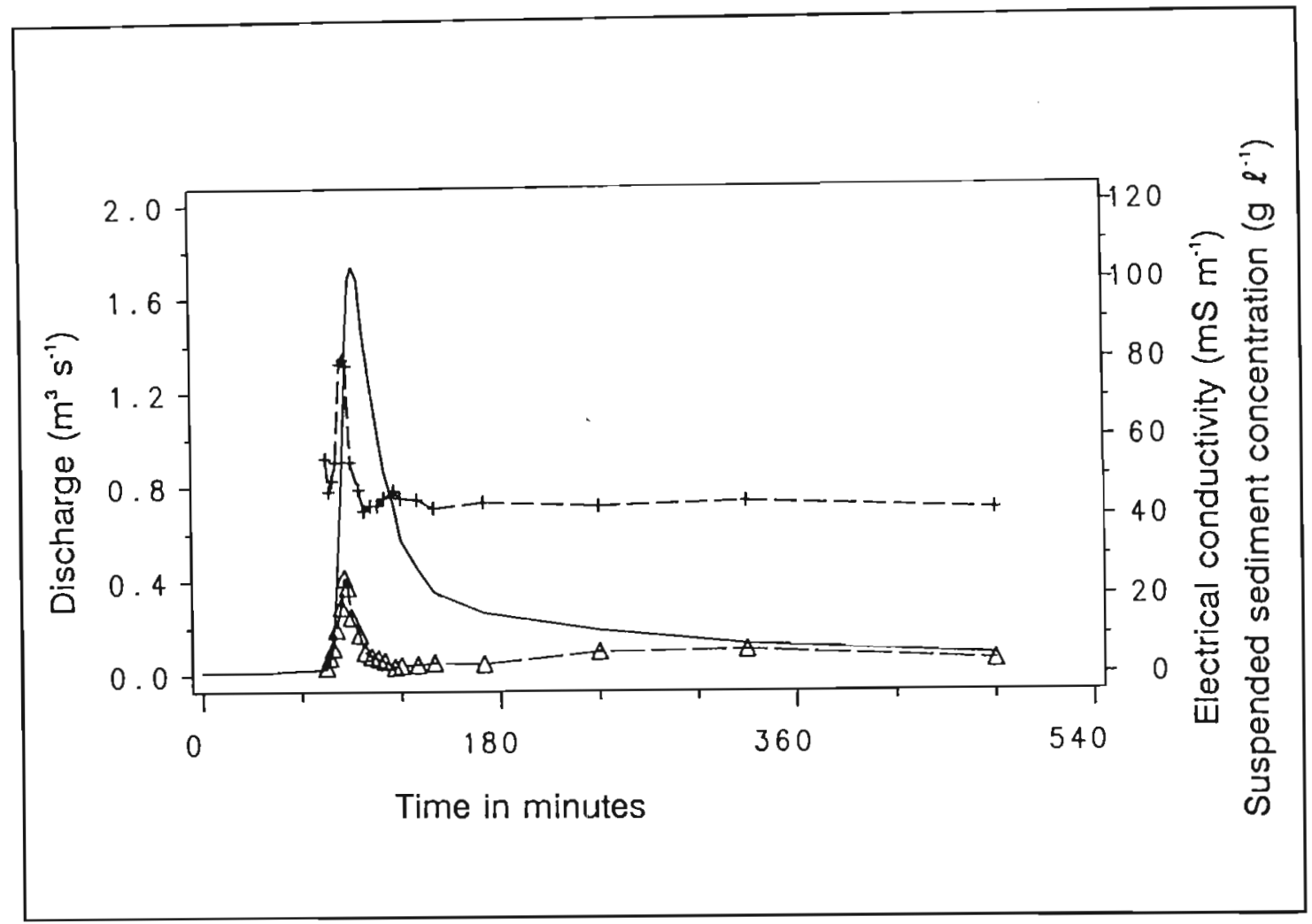

Figure 7.2 Plot of the hydrograph at weir V1H020 (solid line) for 15 December 1989 showing suspended sediment concentrations $(\Delta)$ and electrical conductivity values $(+)$ of water samples taken during the storm.

\subsection{DISCUSSION AND SYNTHESIS}

\subsubsection{Overland Flow, Soil Erosion and Sediment Yields}

\subsubsection{Soil loss off small plots}

An important potential effect of fire is to increase soil erodibility by combusting organic matter which is incorporated into the soil matrix (cf. Section 2.1.3.2). At Ntabamhlope this effect was obvious. Where soil heating was greatest, such as beneath the slash piles, the soils were an ashed black and were powdery to depths of between 5 to $30 \mathrm{~mm}$. Elsewhere the effect of the fire on the soil was less obvious. Hence the greater soil losses from the plots on the slash pile lines ( $75 \mathrm{t} \mathrm{ha} \mathrm{a}^{-1} v s 46 \mathrm{t} \mathrm{ha} \mathrm{a}^{-1}$; Section 7.2.1). There were large 
rills (up to $60 \mathrm{~mm}$ deep) down the lines of the slash pines, while rilling elsewhere was on a smaller scale.

A transport medium is also needed before erosion can take place. Although the sampling apparatus in V1H02O caught primarily water-borne sediments, large amounts of soil, ash and litter appeared to have been eroded by winds in the two dry months immediately following the fire. The presence of fire-induced water repellent soils below the soil surface after fire increased the probability of overland flow occurring during rainstorms. The high soil losses after fire in the eucalypt plantation are believed to have been caused by the combination of bared soil surfaces, higher soil erodibility and the occurrence of overland flow during thunderstorms, due in part to the water repellency in the soils. Soils beneath eucalypt trees seem to be particularly prone to the development of water repellent soils (Gilmour, 1968; McGhie and Posner, 1980; Burch et al., 1989). This was also apparent in the results of the wettability field trial in Bosboukloof (Section 4.1.2), and receives further attention in Chapter 10.

Assuming, for example, a typical topsoil bulk density of $1300 \mathrm{~kg} \mathrm{~m}^{-3}$, then a soil loss of 52 $\mathrm{t}$ ha ${ }^{-1}$ would be equivalent to losing a depth of $4 \mathrm{~mm}$ of soil. Under any conditions this is an unacceptably high soil loss, but in these upland soils which are highly leached, and contain much of their nutrient reserves in the surface layer, such a soil loss probably has serious fertility consequences. An average tolerable soil loss for cultivated land in Natal is $10 \mathrm{t} \mathrm{ha}^{-1} \mathrm{a}^{-1}$ (Russell, 1983). If the high post-fire soil losses are averaged over a forestry rotation length of 10 years, then annual soil losses would most likely be within this limit. However, the forestry soils are shallower on average than agricultural soils and are unlikely to receive erosion control measures and fertilisation that can be expected in intensive agriculture. Thus a high soil loss such as that measured in this study will have to be prevented if forest soils are to maintain their productivity.

\subsubsection{Sediment yields and the role of the riparian buffer strip}

The difference between soil loss on the slopes in the plantation $\left(51.5 \mathrm{t} \mathrm{ha}^{-1}\right)$ and those estimated from suspended sediment samples $\left(5.2 \mathrm{t} \mathrm{ha}^{-1}\right)$ is a remarkable $46.3 \mathrm{t} \mathrm{ha}^{-1}$. It is unlikely that bedload sediment losses would have been as high as the suspended sediment losses, and thus the unmeasured bedload would explain but a minor part of this difference. In the field it was obvious that the healthy tussock grassland which surrounds the stream had trapped an enormous amount of the soil eroded from the plantation. A 
mixture of eroded soil and ash was stacked against the upslope side of the grass plants creating a step-like slope. A considerable depth of soil also was deposited on the roads which run along the contour below the plantation.

The efficiency of the riparian zone in trapping sediment can be appreciated by comparing the net catchment soil loss in this study $\left(\sim 10 \mathrm{t} \mathrm{ha}^{-1}\right)$ with that from the $C$ III research catchment at nearby Cathedral Peak. A wildfire in this pine afforested catchment also burnt the afforested riparian zone, and subsequent soil losses of at least $37 \mathrm{t} \mathrm{ha}^{-1} \mathrm{a}^{-1}$ were measured, roughly 20 times higher than from an adjacent grassland catchment Van Wyk, 1986). Without protection of the riparian zone at Cathedral Peak, it appears that the export of soil from the catchment was more efficient than was the case at Ntabamhlope. This is an important result for the forest industry, where factual justification for protection of riparian zones is needed.

\subsubsection{Stream-flow Generation in the Catchment}

\subsubsection{Total stream-flow and base-flow}

Instead of a post-fire increase in stream-flow as would have been expected as a result of a reduction in transpiring biomass and interception (cf. Section 2.1.2), stream-flows were slightly smaller (6\%) and base-flows much less (48\%) than expected. Increased evaporation from the bared and blackened soil surface after the fire, and transpiration from a vigorous coppice growth in subsequent months may have compensated to a large extent for the savings in canopy interception and transpiration. But this does not account for the reduction in base-flow.

It is postulated that the reduced base-flows had two main causes. Firstly, a large part of rainfall inputs to the burned plantation was lost immediately to storm-flows, with the result that, relative to pre-fire conditions, much less rain-water was available for recharge of soilwater and groundwater; hence, base-flow would have been deprived. Secondly, part of the reduction in base-flow is likely to be the result of the abnormally low rainfall season that followed the fire $(668 \mathrm{~mm}$ vs an average $1068 \mathrm{~mm}$ over the 10 months for which the postfire effects were studied), which rendered the prediction model, developed during more "average" rainfall years, relatively inaccurate for the dry period. This second part of the postulation is necessary as it seems impossible that a fire through less than a half of the catchment could reduce base-flows by as much as $48 \%$. The actual mechanism for this 
could be that the dry conditions caused more rain than normal to go into storage, without much being released as base-flow.

There is considerable anecdotal record of base-flow reductions following fire (Nänni, 1960) but no known documented cases of immediate reductions. The vigorous recovery after fire of tall Eucalyptus regnans forest in Victoria, Australia, caused eventual stream-flow decreases of $24 \%$, but starting only from three to five years after the fire (Langford, 1976).

The soil wetness in the Ntabamhlope catchments was not studied, other than the observations of uneven wetting of water repellent soil profiles in the burned catchment. From the the low storm response and low base-flows recorded after the fire (Table 7.1), it can be deduced that the bulk of the rainfall was retained in the catchment, to recharge soil and groundwater and feed evaporation. Observations of soil wetting beneath the eucalypt plantation in catchment $\mathrm{V} 1 \mathrm{HO} 20$ during a wetter period (Everett, 1990) showed a that there was rapid wetting of the profile after an extreme rainfall event (over $200 \mathrm{~mm}$ ) at depths of up to $1.2 \mathrm{~m}$. Thus it is quite likely that some rainfall was recharging soil-water over the whole depth of the profile, by routes as described in Section 4.1.2. But the levels of stored water in the catchment must have remained too low to restore base-flows to those expected.

\subsubsection{Storm-flows}

The marked change to a steeper, larger hydrograph which resulted from the fire is all the more notable because only 40 ha out of the 132 ha V1H020 catchment burned. An eighth of the burned area is a low grassland which forms a streamside buffer zone. This strip has a high basal cover and is burnt regularly as a fire protection measure. So the fire effects can be ascribed wholly to the 35 ha of eucalypt plantation (i.e. $26 \%$ of catchment) which burnt. It can also be assumed that the impact of the fire would have been proportionately greater had more of the catchment been occupied by burned plantation. Furthermore, the rainfall for the 10 months which followed the fire was much lower than normal $668 \mathrm{~mm} v \mathrm{~s}$ an expected $1068 \mathrm{~mm}$ over the same period). An average or above-average rain year is likely to have resulted in, at least, proportionately greater fire effects.

The sharp increases in storm-flows following wildfire recorded in this study were in the same direction, but more marked, than those recorded after the fire in the Bosboukloof catchment (Table 7.3 and Section 4.3.1). Two important differences may be responsible 
for the greater response to fire seen in Ntabamhlope: the greater repellency of soils under eucalypts as opposed to those under pines (i.e. tending to form more of a continuous layer under the eucalypts), and the higher intensity of the rainfalls in the summer rainfall area in South Africa. Large though they are, the storm-flow increases are comparable to fire effects reported from other parts of the world. Cases of large post-fire increases in flooding and sedimentation from eucalypt forests have been reported from Australia (Brown, 1972; Leitch et al., 1983; Table 2.1) and the mountainous chaparral areas of the western USA (Anderson et al., 1976; and others in Table 2.1).

\subsubsection{Synthesis of the Ntabamhlope Results}

In this chapter it has been shown that a high intensity wildfire through a partially afforested catchment caused marked changes to stream-flow generation and consequently to the storm-flow characteristics. Water repellent soils in the plantation contributed to the increased generation of overland flow, which entrained large amounts of ash and surface soil left in a highly erodible condition by the fire. These soil losses are likely to have significantly reduced the nutrient base in the plantation, and therefore have serious fertility implications.

A riparian buffer strip composed of a healthy, short grassland with a high basal cover provided a very effective trap for soils and ash eroded from the burned plantation. It is estimated that only one fifth of the soil loss on the plantation slopes was exported from the catchment in the first ten months after the fire. The remaining eroded soil went into storage in the riparian strip, on the road surfaces and in the stream channel. It is possible that much of this soil would have been flushed from the catchment during large storms in the second wet season after the fire.

\subsubsection{A Comparison of Some Results from the Four Catchment Studies}

\subsubsection{Stream-flow characteristics}

In Table 7.3 the effects of fire in all four of the burned catchments studied are brought together for convenience of comparison. The changes in annual stream-flow are small relative to the changes observed in the storm-flows, which is to be expected as there is a limit to the impact which re-routing and re-distribution of the annual rainfall can have on the annual runoff. It is also apparent that the greatest changes to storm-flow components were 
recorded in the drier catchments. While larger relative changes would be more easily achieved from a lower base-level, this effect is seen as being largely coincidental rather than a functional relationship.

Table 7.3 Tabular summary of fire effects on stream-flow and storm-flow: post-fire mean values and percentage change over expected (predicted) values for several stream-flow and storm-flow variables in the first post-fire year. Change figures in brackets are not significant. Negative percentage change indicates a decrease.

\begin{tabular}{|c|c|c|c|c|}
\hline & $\begin{array}{c}\text { Ntabamhlope } \\
\text { V1H020 } \\
\end{array}$ & Bosboukloof & Swartboskloof & Langrivier \\
\hline $\begin{array}{l}\text { Annual stream-flow } \\
(\mathrm{mm})\end{array}$ & $\begin{array}{l}109 \\
-6 \%\end{array}$ & $\begin{array}{l}733 \\
12 \%\end{array}$ & $\begin{array}{c}1246 \\
15.3 \%\end{array}$ & $\begin{array}{l}1389 \\
9.4 \%\end{array}$ \\
\hline Storm-flow (mm) & n.m. & $\begin{array}{c}6.4 \\
62 \%\end{array}$ & $\begin{array}{c}16.1 \\
(-2.4 \%)\end{array}$ & $\begin{array}{c}30.3 \\
(3.8 \%)\end{array}$ \\
\hline Quick-flow (mm) & $\begin{array}{c}2.1 \\
92 \%\end{array}$ & $\begin{array}{c}3.6 \\
201 \%\end{array}$ & $\begin{array}{c}7.2 \\
(22 \%)\end{array}$ & $\begin{array}{c}20.6 \\
(0.5 \%)\end{array}$ \\
\hline Peak discharge $\left(\mathrm{m}^{3} \mathrm{~s}^{-1}\right)$ & $\begin{array}{c}1.2 \\
1100 \%\end{array}$ & $\begin{array}{c}0.75 \\
290 \%\end{array}$ & $\begin{array}{c}0.32 \\
(19 \%)\end{array}$ & $\begin{array}{c}1.20 \\
(8.4 \%)\end{array}$ \\
\hline Response ratio (\%) & $\begin{array}{c}6.5 \\
319 \% \\
\end{array}$ & $\begin{array}{c}7.5 \\
242 \% \\
\end{array}$ & $\begin{array}{c}11.9 \\
(6.7 \%) \\
\end{array}$ & $\begin{array}{c}36.0 \\
(11 \%) \\
\end{array}$ \\
\hline
\end{tabular}

n.m. = not measured

\subsubsection{Sediment delivery ratios}

The soil loss and overland flow from small plots relative to the yield from all four burned catchments in this study are summarised in Table 7.4. To enable comparisons to be made a bedload of $20 \%$ of total suspended sediment is assumed for Ntabamilope and Langrivier. The table compares the soil loss measured off plots to estimated sediment yields from the catchment as a whole by means of a sediment delivery ratio (sediment yield as a percentage of soil loss from plots). The highest delivery ratio of any of the catchments is the $50 \%$ recorded in Bosboukloof. In the other catchments, despite the large differences in absolute sediment yields, the delivery ratios were much lower, and similar at around $10 \%$.

These differences can be ascribed largely to the condition of the riparian buffer-strips. The indigenous riparian forest in Swartboskloof and Langrivier did not burn to any great extent and so acted as a buffer between the drier hill-slopes and the river. The grassed riparian zone in Ntabamhlope $\mathrm{V} 1 \mathrm{H} 020$ had a high basal cover at all times and the canopy was quick to recover after the fire. In Bosboukloof the high intensity wildfire through the riparian zones left many streams vulnerable and unprotected, with some erosion also taking place in the riparian zone. 
Table 7.4 The mean overland flow and soil loss from small plots (rows 2 - 5) and sediment yields from the whole catchment (rows 6 and 7) for all four burned catchments during the first post-fire year. (Standard deviation, where available, in brackets)

\begin{tabular}{|c|c|c|c|c|c|}
\hline & Bosboukloof & Swartboskloof & Control & Langrivier & $\begin{array}{l}\text { Ntabamhlope } \\
\text { V1H020 }\end{array}$ \\
\hline Number of plots & 3 & 6 & 1 & 3 & 3 \\
\hline $\begin{array}{l}\text { Overland flow }(\mathrm{mm}) \\
\text { mean per storm }\end{array}$ & n.m. & $\begin{array}{l}1.87 \\
(0.71)\end{array}$ & 0.49 & $\begin{array}{l}1.11 \\
(0.08)\end{array}$ & n.m. \\
\hline As $\%$ of rainfall & n.m. & $\begin{array}{l}4.9 \\
(2.04)\end{array}$ & 0.81 & $\begin{array}{l}2.18 \\
(0.13)\end{array}$ & n.m. \\
\hline Soil loss (t ha $\left.{ }^{-1}\right)$ & $16^{2}$ & $\begin{array}{l}2.42 \\
(2.5)\end{array}$ & 0.013 & $\begin{array}{l}1.15 \\
(0.92)\end{array}$ & $\begin{array}{l}60.0 \\
(13.6)\end{array}$ \\
\hline $\begin{array}{l}\text { Per unit of rainfall } \\
\text { (kg per } 100 \mathrm{~mm} \text { ) }\end{array}$ & $\begin{array}{l}34.23 \\
(42.89)\end{array}$ & $\begin{array}{l}1.00 \\
(3.61)\end{array}$ & 0.005 & $\begin{array}{l}0.48 \\
(1.21)\end{array}$ & $\begin{array}{l}49.0 \\
(11.1)\end{array}$ \\
\hline Suspended sediment $\left(t \mathrm{ha}^{-1}\right)$ & $6^{2}$ & $0.41^{3}$ & n.m. & $0.148^{4}$ & 5.2 \\
\hline Total sediment yield $\left(t \mathrm{ha}^{-1}\right)$ & $7.8^{2}$ & $0.42^{3}$ & n.m. & n.m. & n.m. \\
\hline Approximate delivery ratio ${ }^{5}$ (\%) & 50 & 8 & n.m. & $8^{6}$ & $12^{6}$ \\
\hline
\end{tabular}

1. = single unburnt control plot for both Swartboskloof and Langrivier

2. $=$ from Scott and Van Wyk 1990

3. $=$ from Scott and Van Wyk 1992

4. $\quad=\quad$ Van Wyk and Lesch 1989

5. $\quad=\quad$ Catchment sediment yield as percentage of plot soil loss

6. $\quad=\quad$ assumes bedload is $20 \%$ of suspended sediment

n.m. = not measured

This chapter documents the marked effects of a wildfire in the dry season on the hydrological behaviour of a partially afforested catchment in an area subject to higherintensity thunderstorms. These results confirm the potential of wildfire in conjunction with water repellent soils to change the mode of stream-flow generation, as first demonstrated by the Bosboukloof fire (Chapter 4). If such large changes in hydrological behaviour are possible, then it is important to be able to predict the potential impact of wildfires on the hydrological behaviour of catchments, for reasons of planning and public safety. In an effort to fill this need, the next chapter records an exercise to use an existing model to simulate the large changes in hydrological behaviour that were recorded in this Ntabamhlope catchment following the wildfire. 


\section{CHAPTER 8}

\section{MODELLING THE HYDROLOGICAL EFFECTS OF FIRE}

The high-intensity wildfire which burned the forested portion of the Ntambamhlope catchment in August 1989 caused a marked change in the hydrological behaviour of the catchment during the first subsequent wet season (Chapter 7). The change in stream-flow generation is believed to have been caused by increased overland flow which resulted in shorter times of concentration and higher peak discharges during storms. Increased overland flows were linked to the widespread presence of water repellency in the soils of the plantation, which altered the mode of stream-flow generation in the catchment: This chapter describes the use of the ACRU agro-hydrological model to simulate these hydrological effects in a fairly deterministic manner. The rationale for undertaking a modelling run was to mobilise the findings of the detailed process studies so that catchment-specific results could be generalised for application to a broader geographical area, and to enable the prediction of the impacts of wildfires where no observed hydrological data are available.

\subsection{DESCRIPTION OF THE ACRU MODEL}

The ACRU model is a multi-layer soil water budgeting model based on physical principles. The model uses a daily time step and has been developed into a versatile total evaporation model, which has been structured to be sensitive to land-use changes. The structure of the ACRU model is illustrated in Figure 8.1 and is described in detail by Schulze (1989a). Version 2.15 of $A C R U$, as available in early 1991 to the broad hydrological community through the facilities of the Computing Centre for Water Research, was used for this simulation exercise. The intention was to use a generally available model and not to embark on model development or refinement of the ACRU model.

Two further aspects of $A C R U$ made it attractive for this modelling exercise. Firstly, the model can be run in a semi-distributed mode, whereby the catchment is split into a number of hydrologically interlinked sub-catchments. Secondly, the model can be run with a socalled dynamic input file whereby certain input parameters may be changed over time. 
This capability would enable the simulation of temporal changes, such as a fire on a certain date and forest re-growth, over time in a single run of the model.

Of the potential outputs from the model, I was interested in companing the simulated stream-flow components (total flow and storm-flow volume) with those which had been observed. The following description of the manner in which the model simulates these is taken from Schulze (1989b). In the ACRU model the generated stream-flow comprises base-flow and storm-flow, with the storm-flow consisting of a quick-flow response (i.e. storm-flow released into the stream on the day of the rainfall event) and a delayed stormflow response. Base-flow is derived from a groundwater store which is recharged by drainage out of the lower soil horizon when its water content exceeds field capacity (Figure 8.1).

Storm-flow volume is simulated by a continuous water budget version of the Soil Conservation Service (SCS) of the United States Department of Agriculture (USDA, 1972) hydrograph generating technique as adapted for South African conditions by Schulze (1984). The generation of storm-flow is based on the premise that, after initial abstractions, the runoff produced from a single day's rainfall is a function of the soil-water deficit from a critical response depth in the soil. The soil-water deficit before a rainfall event is simulated by budgeting the water content of the various soil layers (Figure 8.1). The proportion of the simulated storm-flow volume generated on a given day which exits the catchment on subsequent days is controlled by a decay coefficient.

The ACRU model is also able to estimate peak discharge by means of the SCS (USDA, 1972) unit hydrograph concept (Schulze, 1984). When the model is run in distributed mode, a hydrograph is simulated for each cell. As this is a daily model, uniform distribution of the daily rainfall is assumed, and hence a single rather than incremental unit hydrograph is used for computation of the peak (Schulze, 1989a). In the ACRU 2.15 used in this simulation there was no facility to route the peaks from the individual cells in a realistic manner and hence the simulation of peak discharge for the simulation as set up for catchment $\mathrm{V} 1 \mathrm{H} 020$, and bearing in mind the small portion of the catchment which was affected by the fire, would have been inappropriate. The modified universal soil loss equation (MUSLE) has also been imbedded in the ACRU model to estimate sediment yield (Schmidt, 1989). However, as this sub-model is strongly dependent on the estimate of 


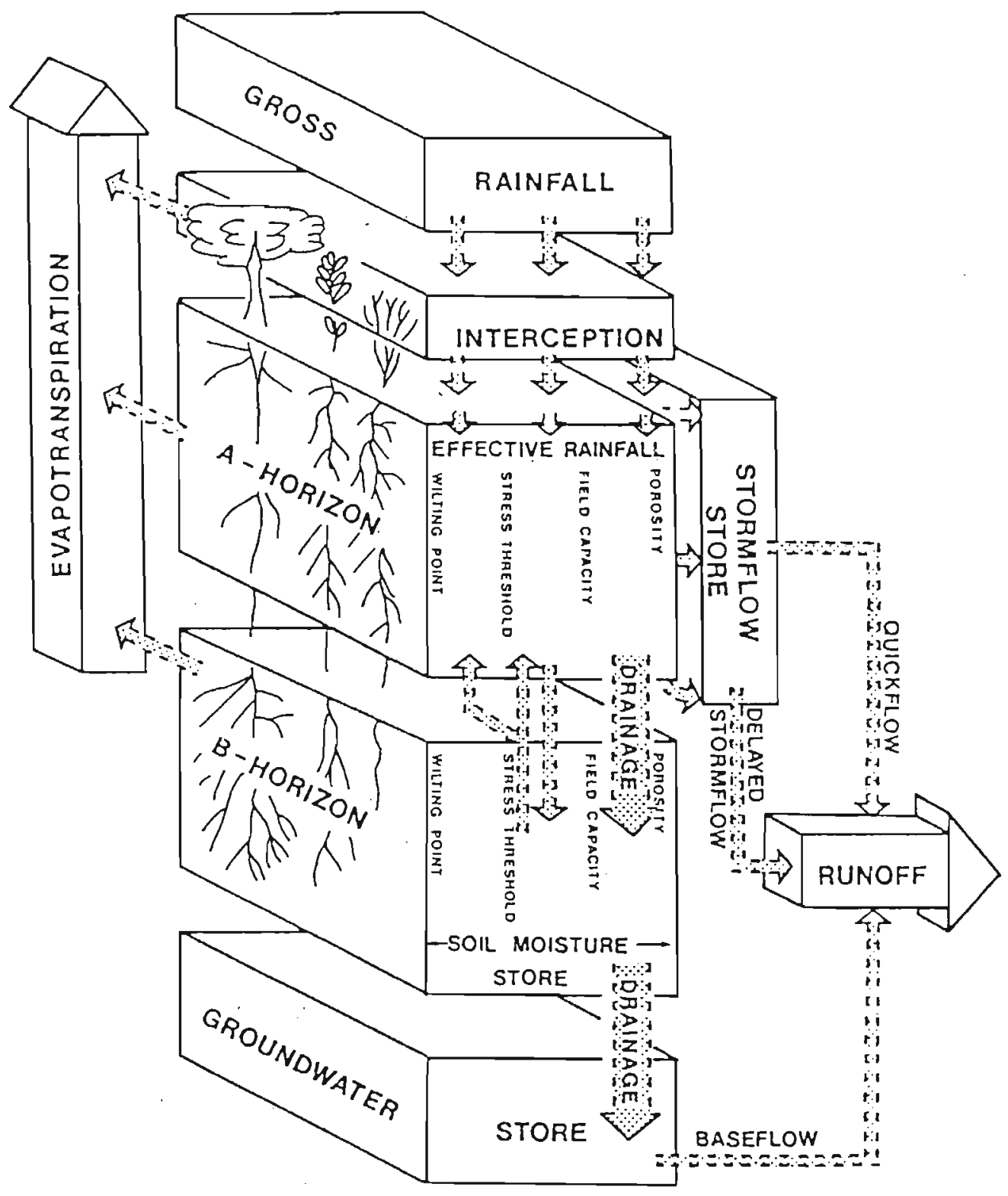

Figure 8.1 A diagrammatic depiction of the structure of the ACRU agro-hydrological model, Version 2

peak discharge as the transport medium its use in this case would also have been inappropriate. Versions of the ACRU model available at the time of writing have none of the above-mentioned limitations, and would make simulation of both peak discharge (with disaggregated rainstorms) and sediment yield possible. 


\subsection{SETTING UP THE ACRU MODEL}

\subsubsection{The ACRU Model in Distributed Mode}

The model was set up to simulate in a distributed mode, with the catchment divided into five sub-catchments as shown in Figure 8.2. This allowed

(i) the sub-division of the catchment into relatively homogeneous segments which had different vegetation types (grassland or timber plantation),

(ii) a check of the simulated flows in the upper, untreated catchment, V1H028, against its actual stream-flow without the compounding effect of a fire, and

(iii) confinement of the effects of the fire to only those sub-catchments which had actually been burned (sub-catchments 3,4 and 5 in Figure 8.2).

The catchment properties (soils, land cover, eg.) are well documented (Schmidt and Schulze, 1989) and consequently accurate values were available for input to the model. The critical driving variable in $A C R U$ is daily rainfall and this was obtained from two recording gauges within the catchment. Daily pan evaporation values were available from the meteorological site at the Ntabamhlope Research Station $2 \mathrm{~km}$ from the catchment.

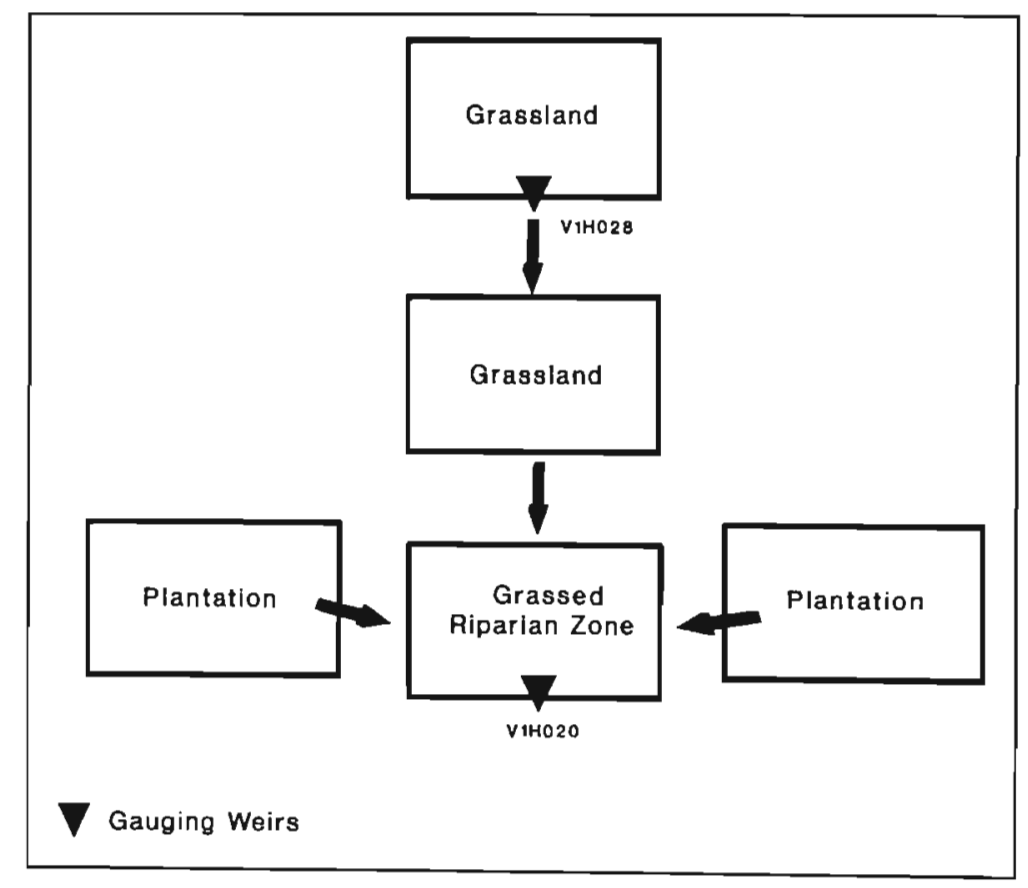

Figure 8.2 The layout and vegetation types of the subcatchments within catchment $\mathrm{V}_{1} \mathrm{H}_{\mathrm{O}} 2 \mathrm{O}$ at Ntabamhlope for purposes of distributed modelling. 


\subsubsection{The Dynamic Information Menu to Account for the Effects of Fire}

To account for the effect of fire within a single run of the model, ACRU's dynamic information input capability was invoked to alter certain variables to new values from September 1989. The first and obvious effect of the fire was to kill all aerial parts of the vegetation, so that canopy and litter interception was removed, and transpiration halted. This was modelled by reducing interception to $0 \mathrm{~mm}$ per rain-day in the first month after the fire (Figure 8.3) and increasing it gradually to account for the rapid re-growth of coppice that was observed in the catchment. Similarly, the crop coefficient was dropped to a minimum value of 0.45 after the fire and its recovery followed that of the canopy (Figure 8.3). All root activity in the model was re-set to be confined to the topsoil where initially only germinating seedlings were actively extracting soil-water for transpiration.

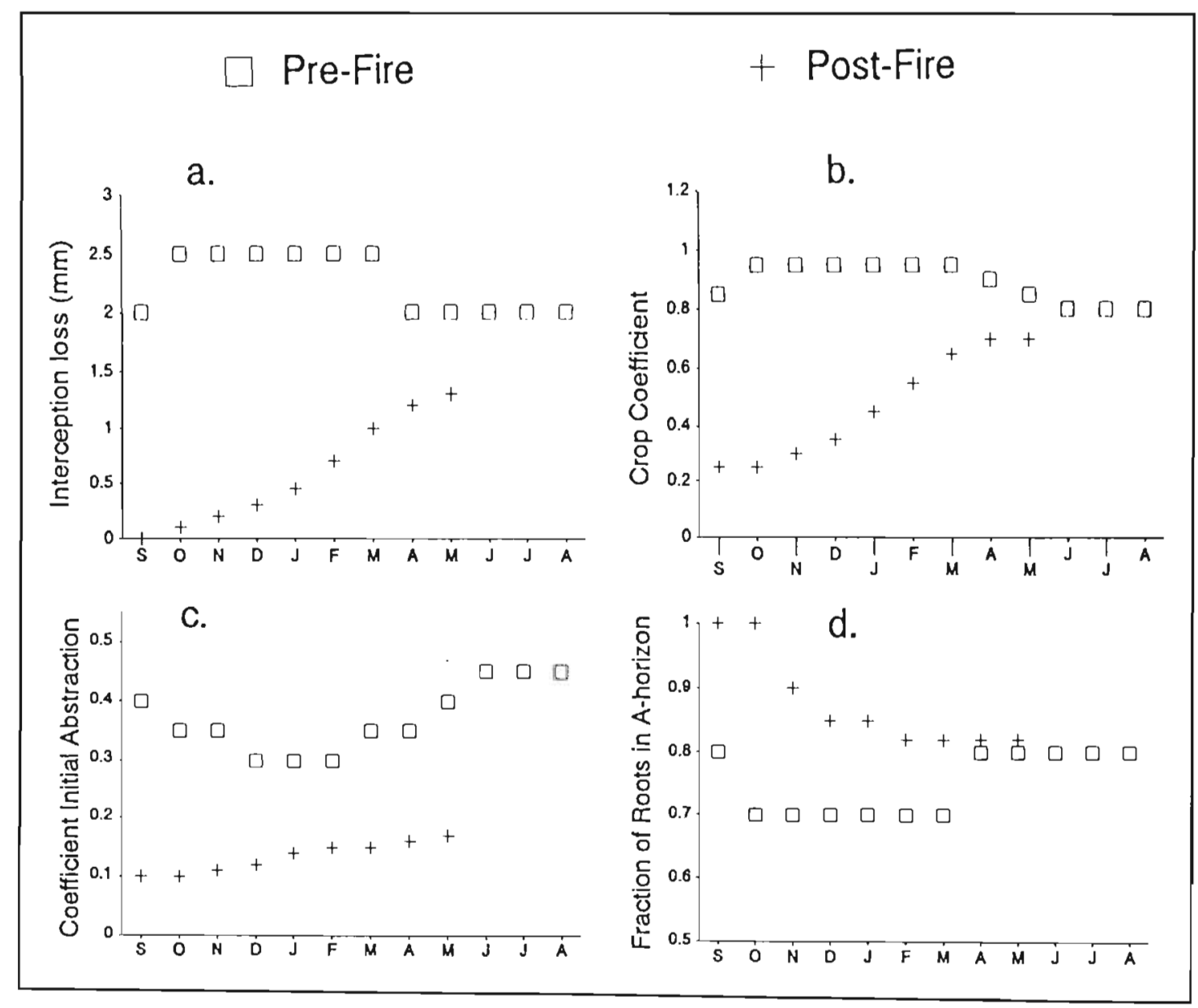

\section{Figure 8.3}

The monthly values of four model variables showing how they were set to accommodate before and after fire conditions in the burned sub-catchments at Ntabamhlope. 
The coefficient of initial abstraction (Figure 8.3), which accounts for rainfall abstractions by litter interception, initial infiltration and depression storage before runoff commences, was reduced to account for the removal of surface storage in the burned catchment (thereby increasing net rainfall). The changes of the monthly values of the above inputs parameters are plotted for the forested sub-catchments in Figure 8.3 to illustrate the means by which $A C R U$ was to account "dynamically" for the hydrological impact of the fire for the first nine months after the fire.

The critical soil depth for which the soil water deficit is calculated for runoff generation procedures in $A C R U$, was reduced from $0.4 \mathrm{~m}$ to $0.15 \mathrm{~m}$ in the burned plantation cells for the post-fire period to account for the influence of water repellency in the soils. Rainfall in excess of the daily water deficit in this critical soil depth parameter (termed SMDDEP) is utilised in stream-flow generating routines by the model. Neither the original value nor post-fire values reflect the actual depth of the water repellent layer in the soil, but are an approximation to account for the spatial average of infiltration and the effect of litter to store water against overland flow over the plantation floor. (While observation had shown that unburned soils were also water repellent, for reasons given elsewhere the effect of this phenomenon has limited impact on runoff generation while ground litter loads are high.)

It should be noted that $A C R U$, as a physical conceptual model, is not calibrated to attain acceptable fits, but that all parameters which were affected were changed for physically accountable reasons. The direction and extent of an adjustment to a model parameter is therefore limited. However, as single parameter values have to be chosen to represent each sub-catchment some averaging is done to account for scale and natural variability and, also, as some model parameters are conceptual rather than physical (such as SMDDEP) a degree of experience is required of the modeller. It can be argued therefore that the selection of appropriate values for some parameters is subjective and is is a form of calibration. 


\subsection{COMPARISON OF SIMULATED AND OBSERVED STREAM-FLOWS}

\subsubsection{Observed Stream-flow Effects}

Fire changed all the storm-flow variables from their expected behaviour based on the relationship with the control catchment (Table 7.1). In essence the storm hydrographs were larger and higher after the fire. The sample hydrographs plotted in Figure 7.1 clearly illustrate the change in relationship between the two catchments which resulted from the fire. Before the fire, discharge per unit area was greater from the smaller, upper catchment, though the shape of the hydrograph was similar in both catchments, with a short delay in peaking at the lower station (Figures 7.1a \& 7.1b). After the fire, the larger catchment, of which the control is a part, had a relatively much greater discharge, with higher peaks and a very rapidly rising limb of the hydrograph. Storm duration was not markedly affected by fire; stream-flow quickly returned to pre-storm levels, despite the greatly increased total storm-flow volume (Figures $7.1 \mathrm{c}-7.1 \mathrm{f}$ ).

\subsubsection{Simulated Stream-flow}

The daily and monthly stream-flow totals were generated with $A C R U$ and compared to the observed values. For all single rainstorms of above $15 \mathrm{~mm}$, the storm-flows simulated in each of the five cells of the model were summed to give a total storm-flow volume from the catchment per storm.

\subsubsection{Total stream-flow}

The monthly totals of simulated daily stream-flow were generally satisfactory (Figure 8.4), although base-flows in the dry winter months were consistently under-simulated, both before and after the fire. Daily stream-flow volumes were also over-simulated during the dry season and during that the early part of the wet season when the catchment is wetting up after the long dry season (Figure $8.5 \mathrm{a}$ and $8.5 \mathrm{c}$ ). This is thought to be largely because of the problems of generally over-simulating flows from a "dry" catchment (a feature which has often been observed in the use of ACRU, according to RE Schulze, 1993, personal communication'). 


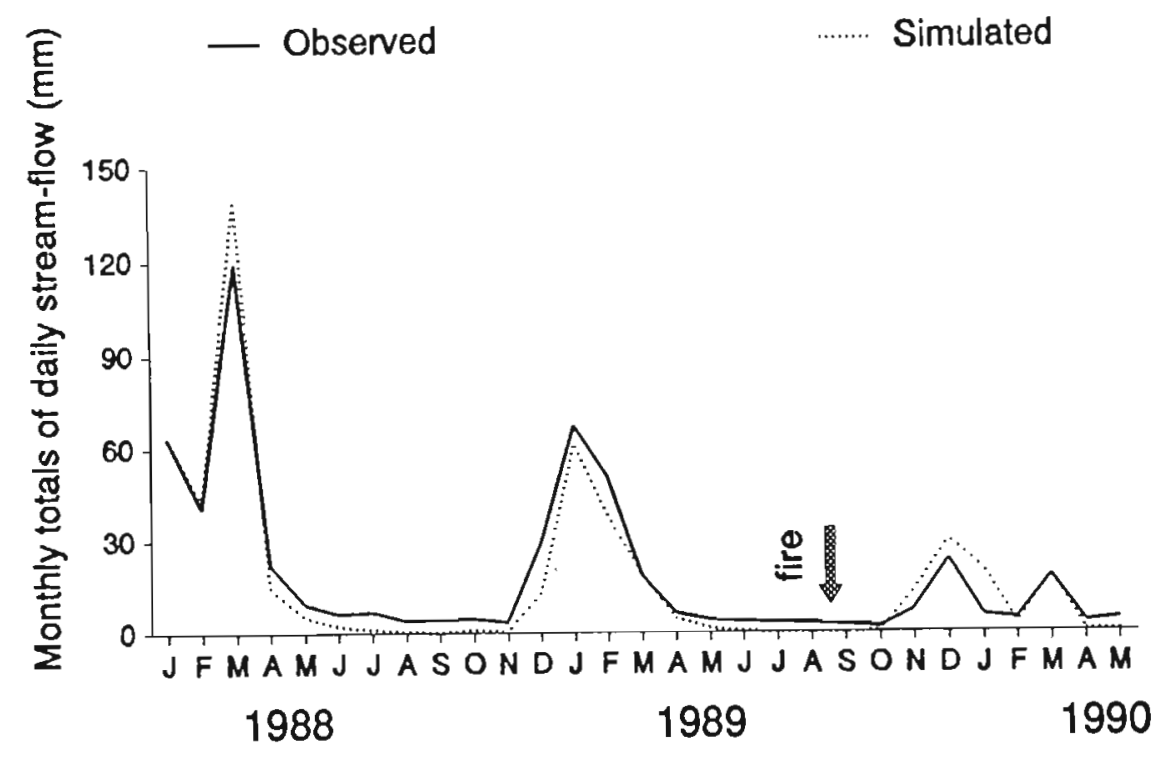

Figure 8.4

Time-plot of the observed and simulated monthly totals of daily streamflow for catchment $\mathrm{V} 1 \mathrm{H} 020$ at Ntabamhlope.

The over-simulations obtained in the post-fire months of December and January (Figure $8.5 d)$ stem from the over-simulation of storm-flows in the period while the catchment was wetting up. A minor part of this error derives from the upstream grassland sub-catchments in the simulation. In the post-fire period base-flows were again over-simulated (Figure $8.5 c)$.

\subsubsection{Storm-flow}

The simulated storm-flow volumes were generally higher than the observed storm-flows, and more so after the fire (Figure 8.6). Before the fire, moderate to large storms (25 - 100 $\mathrm{mm}$ ) seem to have been over-simulated because the actual storm had been generated by low intensity rainfall events (ACRU as a daily model, does not account for rainfall intensity). These storms are of minor importance for planning purposes, and from this perspective such an error is considered acceptable. After the fire almost all the storms were oversimulated. This is thought to be partly because of the afore-mentioned problem of generally over-simulating flows from a "dry" catchment (Section 8.3.2.1), and partly because of over-adjustments to account for the effects of fire. 


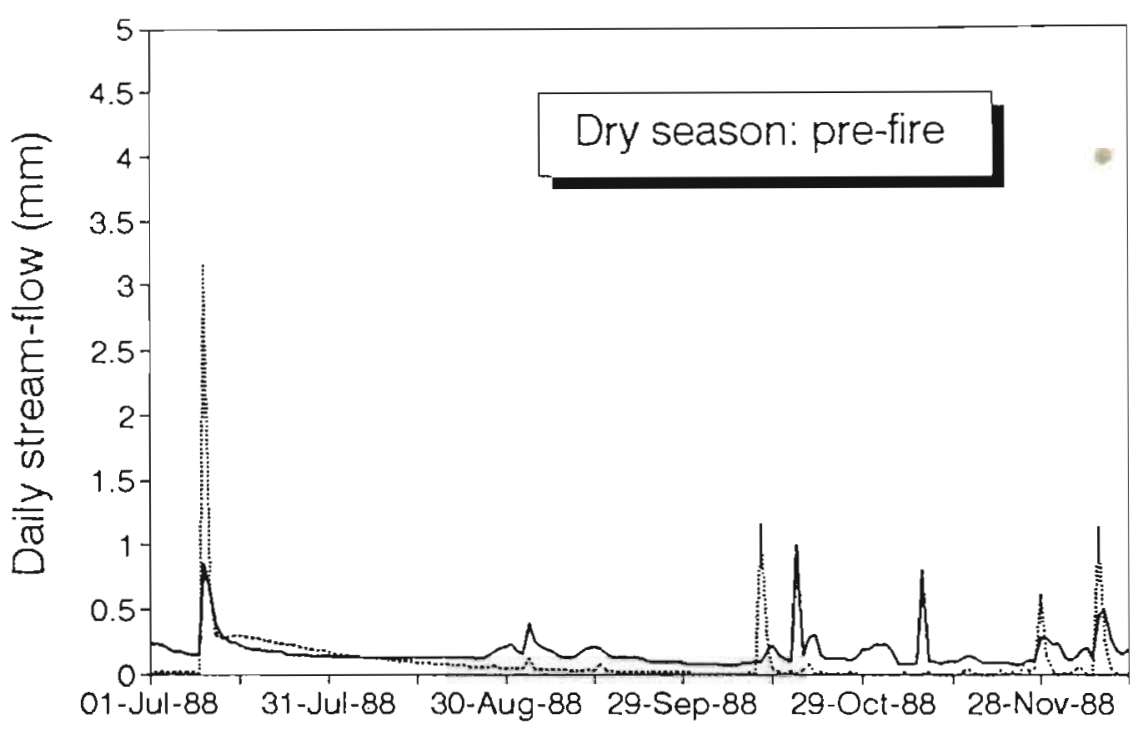

16-Jul-88 15-Aug-88 14-Sep-88 14-Oct-88 13-Nov-88 13-Dec-88

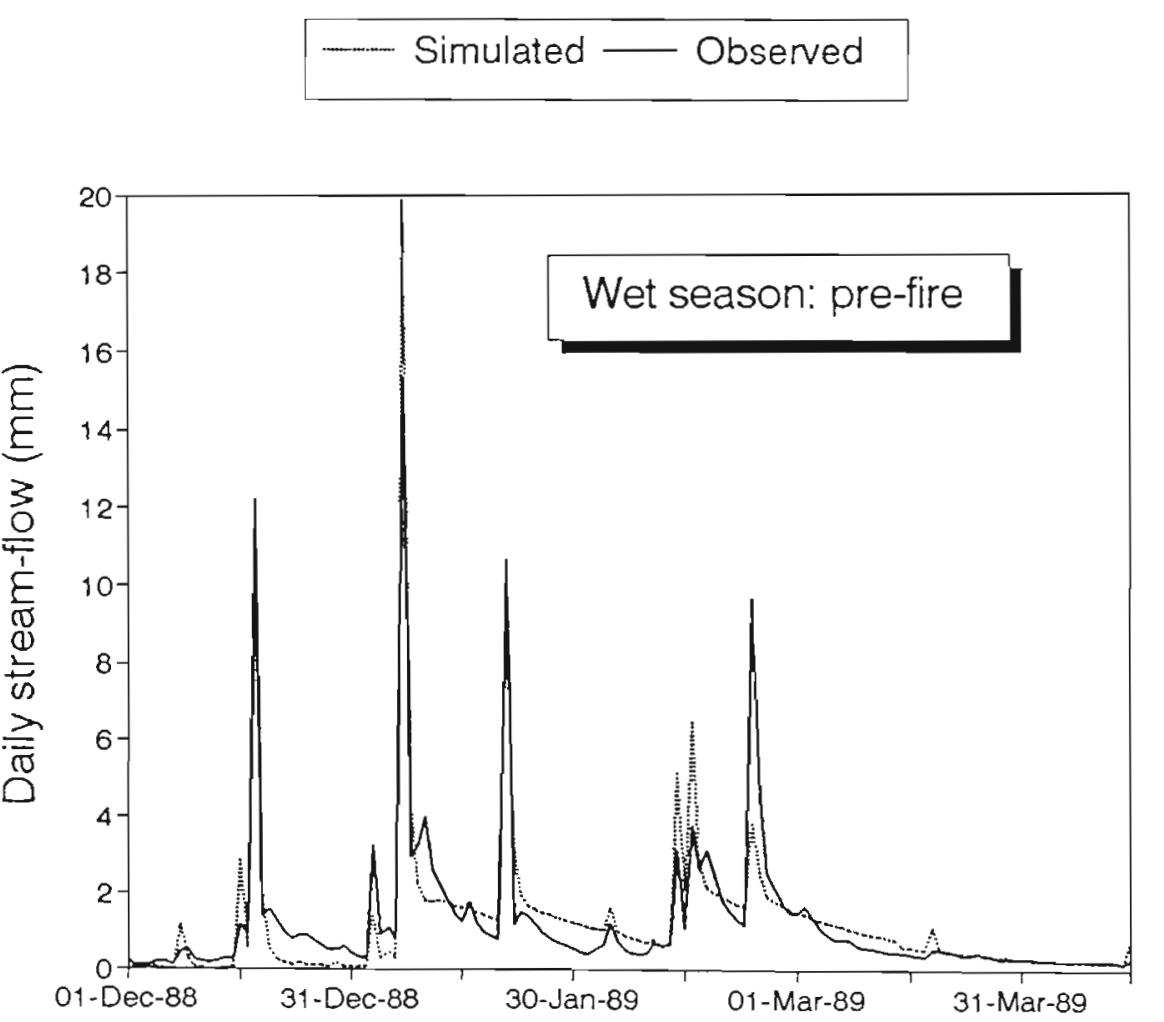

16-Dec-88 15-Jan-89 14-Feb-89 16-Mar-89 15-Apr-89

Figure 8.5a Time plots of the observed and simulated daily stream-flow volume in Ntabamhlope catchment $\mathrm{V}_{1} \mathrm{H}_{02} \mathrm{O}$ for dry and wet periods before the fire. Note the scale differences on the vertical axes. 


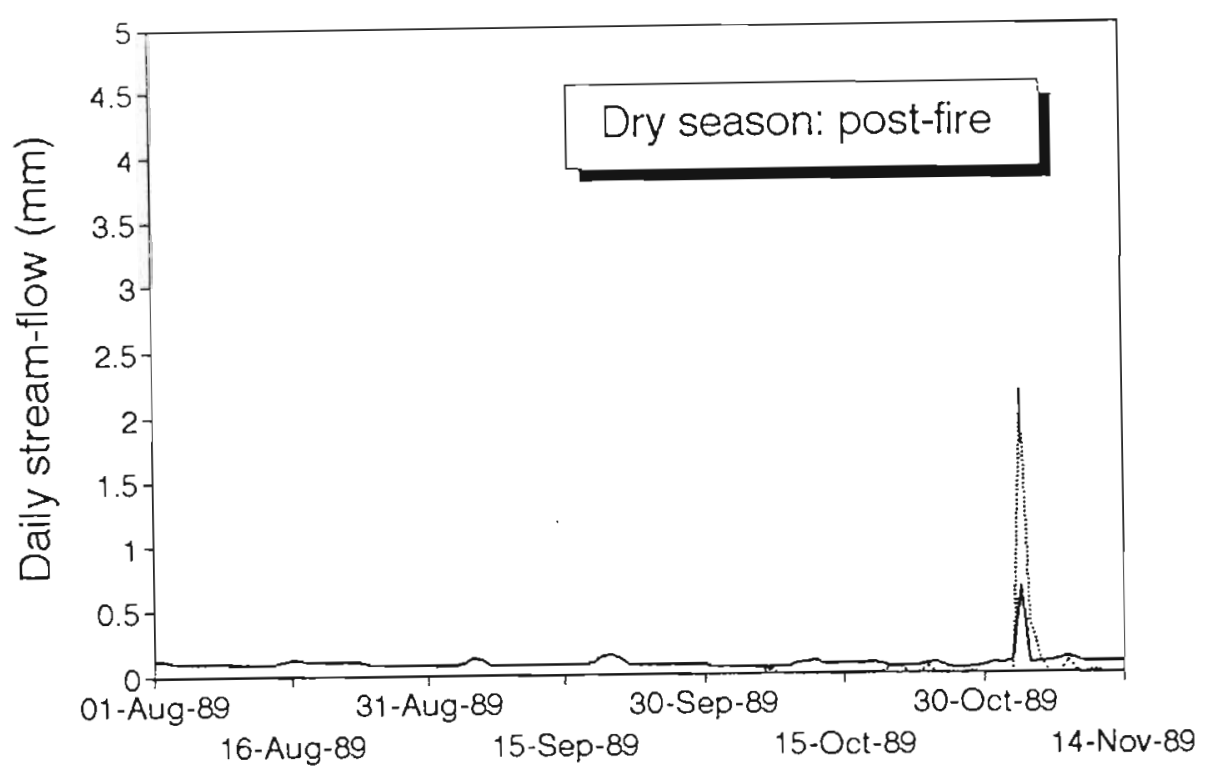

- Simulated - Observed

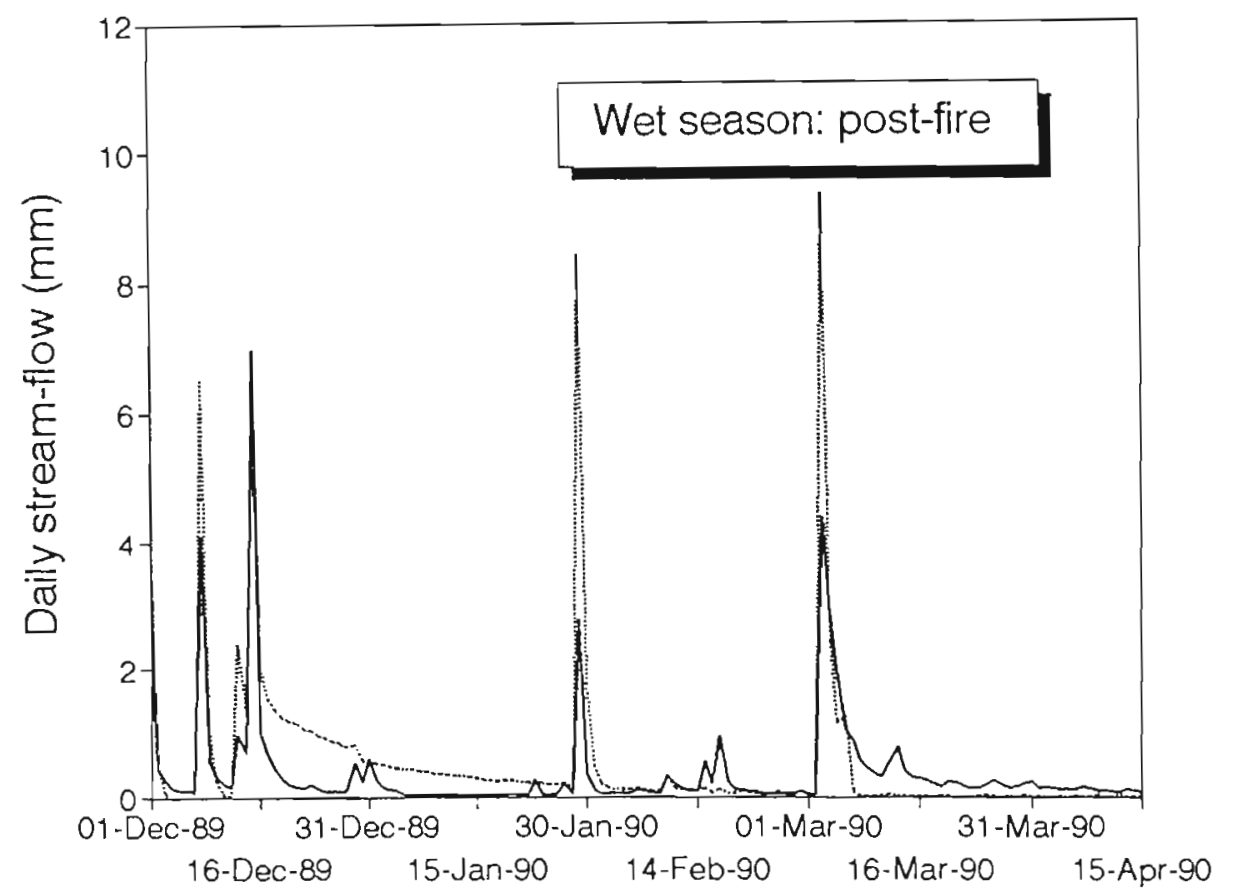

Figure 8.5b Time plots of the observed and simulated daily stream-flow volume in Ntabamhlope catchment $\mathrm{V}_{1} \mathrm{H} 020$ for dry and wet periods after the fire. Note the scale differences on the vertical axes. 


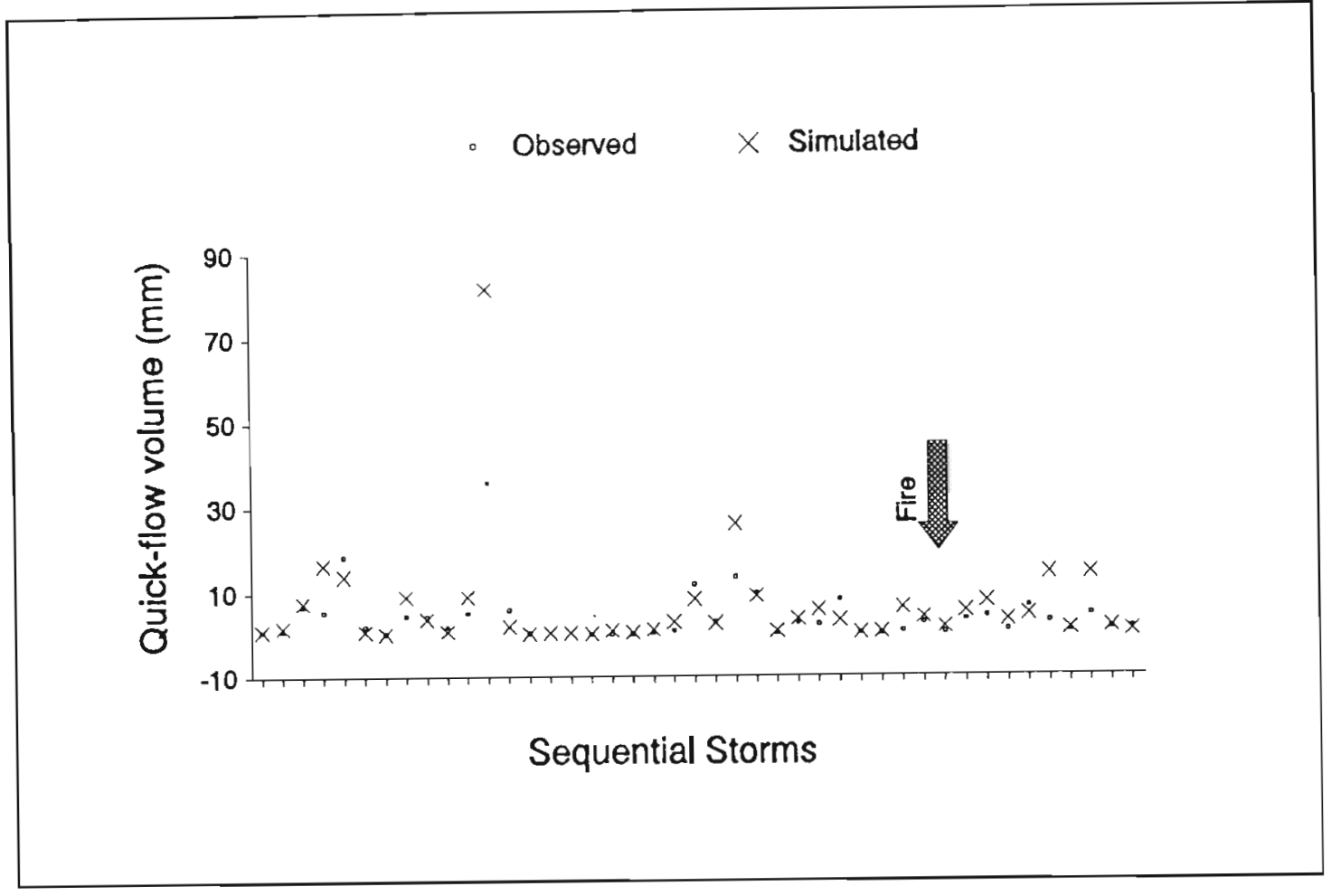

Figure 8.6 Time-plot of the observed and simulated storm-flow volumes for individual storms in catchment $\mathrm{V}_{1} \mathrm{H} 020$ at Ntabamhlope.

\subsection{DISCUSSION AND CONCLUSIONS}

This simulation has illustrated the ACRU model's versatility in that an abrupt hydrological impact such as a fire can be modelled with moderate success, and the impact confined to the actual parts of the catchment which are affected. Consequently, realistic subcatchment values for the hydrological control parameters could be used in the model, i.e. without areal averaging across the largely unaffected catchment.

The results show that the model is fairly sensitive to the relatively minor changes to input parameter values that were made, in that these changes allowed successful modelling of the markedly increased storm-flow volumes recorded after the fire. In particular it seemed that small changes to the critical soil depth for generating storm-flow could easily lead to over-estimates in storm-flow volumes. This finding is probably due to low runoff response to rainfall (in absolute terms) of well-vegetated, humid and highly leached catchments (such as $\mathrm{V} 1 \mathrm{H} 020$ ). Although storm-flow response increased markedly as a result of the fire, the proportion of rainfall which was leaving the catchment as storm-flow was still 
relatively small $(6.5 \%)$, and it was therefore comparatively easy to over-estimate this minor proportion.

The rather unusual rainfall pattern in the wet season after the fire made the modelling somewhat difficult because of simulation errors which occurred during the wetting of the dry catchment and during the long dry periods. However, the realistic way in which total stream-flow from the catchment was simulated after the fire is encouraging. The modelling of storm-flow generation appears to mimic the likely process in the field, in that large rainstorms caused and overland flow and storm runoff without necessarily recharging the whole profile. Consequently base-flows remained low. This lends support to the hypothesis that overland flow contributes to storm-flow generation in those wildfire sites where water repellency occurs in the soils. Before the fire little rain water would have reached the stream as overland flow, but after the fire, water repellent soils in the burned eucalypt plantation would have generated a considerable overland flow contribution to storm-flows. Yet the soil water store was still not fully recharged, and consequently baseflows generally remained low during the wet season. These points are in agreement with the finding in the regression analysis that stream-flow in the post-fire period became more responsive to rainfall depth (Section 7.3.1).

This simulation exercise has demonstrated the potential for using ACRU as a planning tool. The magnitude of floods, or the increased size of floods following wildfire in a catchment, can therefore be predicted with some success. This is of course desirable for catchments for which suitable records are not available, and will find particular application where forested catchments are situated above urban developments.

This chapter has described the use of an existing model to simulate the hydrological effects of fire. Such modelling provides the capability to apply the findings of the catchment studies more generally and, specifically, in areas where hydrological observations are absent. In the next chapter the potential of a wide geographical range of South African soils to develop water repellent characteristics is investigated. The probability of water repellency occurring provides a basis for predicting the flood risk that is associated with fire. 


\section{CHAPTER 9}

\section{SOIL WETTABILITY IN FORESTED AND MOUNTAIN CATCHMENTS}

In Chapters 4 and 7 it was shown that wildfire had a marked impact on the hydrological behaviour of some small catchments, and that water repellent (i.e. non-wettable) soils played a major part in effecting this change. The Swartboskloof and Langrivier fires (Chapters 5 and 6) produced less pronounced and more patchy water repellency in the soils, which was associated with minor overall fire effects. Early on in this study it also became clear that severe water repellency in soils was not confined to burned sites. Therefore it was decided to determine how prevalent water repellent soils were in forestry and mountain catchment areas of South Africa, and to what extent this phenomenon was associated with specific vegetation types.

In this chapter an investigation into the role of different vegetation types, and, to a lesser extent that of the soil characteristics, in controlling soil wettability is reported. Representative soils from several important timber-growing areas in South Africa were sampled from beneath plantations of different timber species and adjacent natural vegetation, and subjected to a range of standard wettability tests. Results from these and other tests are presented below, and the implications of these results are discussed.

\subsection{BACKGROUND, SAMPLING AND METHODS}

\subsubsection{Background to the Study}

Soils are generally assumed to be completely wettable because of the strong attraction between the soil particles and water molecules. It is not uncommon though for some soils to show resistance to wetting, i.e. that they are water repellent, hydrophobic or hard-to-wet. This condition may be noticeable in the dry state only with certain soils or at all stages of wetting. 
In most cases water repellency in soils can be attributed to coatings on the soil particles of hydrophobic substances of organic origin. One of the more common sources of these organic skins are fungal mycelia (Bond and Harris, 1964; Jex et al., 1985), which are particularly noticeable in lawns and pastures as the so-called "fairy-ring" phenomenon, causing dead circles of grass where the soils are non-wettable (DeBano, 1981). Water repellency is also commonly associated with certain vegetation types or plant species, such as citrus orchards (Jamison, 1947; Bishay and Bakhati, 1976) and some Californian desert plants, where repellency is confined within the drip zone of the plants (Adams et al., 1969), to chaparral vegetation (DeBano et al., 1967; Holzhey, 1969) and some eucalypts (Bond, 1964; McGhie and Posner, 1980; Burch et al., 1989).

If water repellency is caused by a coating on soil particles it follows that soils with a low specific surface (surface area per unit of mass), i.e. coarse textured soils, should develop the phenomenon more readily. Thus sand is often particularly repellent, as found in Florida (Jamison, 1947), Australia (Roberts and Carbon, 1972), Egypt (Bishay and Bakhati, 1976), and the Netherlands (Ruyten and de Goede-Hiensch, 1988), and as observed in the coastal sands in Zululand and the Cape Flats in South Africa. Other factors positively related to the degree of water repellency are the amount of organic matter in the soil Nan't Woudt, 1959; Scholl, 1971), the age of the vegetation (period since last fire) through controlling the build-up of plant litter on the soil (Teramura, 1980), and the dryness of the soil (Gilmour, 1968; Singer and Ugolini, 1976; Grelewicz and Plichta, 1983) which may result in the seasonal appearance of water repellency. Finally, as has been described in Chapters 2 and 4 , soil heating, such as may occur during fire, has been found to intensify water repellency in the soil (DeBano and Krammes, 1966; Dyrness, 1976; John, 1978; W. Bond, 1989, personal communication').

\subsubsection{Soil Wettability and its Measurement}

Wetting is a complex phenomenon, the theory of which is dealt with in the chemistry and physics of surfaces. It is not the object of this chapter to present the theory behind this subject, but as background to the study it is useful to understand how some of the methods of measurement are derived. 
Water repellency or soil wettability is not an absolute state; factors such as surface chemistry, surface roughness and porosity may all influence perceived repellency, which also varies according to soil wetness and temperature, and possibly also atmospheric humidity (Hammond and Yuan, 1969; King, 1981). Hence the wettability of a soil is not static.

Consequently, there is no single complete method for measuring repellency. The study objective may also determine the method of measurement that is chosen. There is no universally accepted or absolute measure of repellency, and results obtained from different studies are therefore not necessarily directly comparable. Relative scales (such as the Rl index used in Chapters 4-7) may be set so as to be meaningful for a particular sample of soils, and thus may differ between different studies. Some of the commonly used methods of measuring repellency are described below.

\subsubsection{Water penetration time}

Wettability is most easily conceived by the speed with which a water drop penetrates a soil, or is absorbed. Anything less than immediate absorption indicates less than perfect wettability. This is a quick test suitable for use in the field. The test in reality often measures persistence or stability of repellency, as drops which initially are not absorbed may enter the soil after some period of time (DeBano, 1981). An analogous test is that of a miniature ring infiltrometer as proposed by King (1981). Here the time for a known volume or depth of water to be absorbed is measured, and expressed as an infiltration rate.

\subsubsection{Liquid-solid contact angle}

The wetting angle between a liquid and a solid, formally termed the liquid-solid contact angle, is also used to describe the wettability of the solid's surface. In porous media this contact angle is determined from a capillary tube model and refers to the apparent angle the water meniscus makes with the pore wall (DeBano et al., 1967). In soil-water systems the contact angle is usually assumed to be zero, though laboratory determinations of the apparent advancing contact angle seldom show this for even readily wettable soils. 
The capillary rise equation is

$$
h=\frac{\gamma \cos \theta}{\rho g r}
$$

where $h=$ height of rise

$$
\begin{array}{ll}
r & =\text { surface tension of the liquid } \\
r & =\text { radius of capillary (or pore) } \\
\rho & =\text { density of the liquid } \\
g & =\text { gravity and } \\
\theta & =\text { solid-liquid contact angle. }
\end{array}
$$

This equation has been used to derive the following simple laboratory technique to measure the apparent advancing contact angle (Letey et al., 1962). The method depends on the fact that ethanol wets all solids with a contact angle of zero. Two columns of soil are packed with the same soil to the same density such that $r$ can be assumed to be equal in the two. One column is placed in ethanol and the other in water and the height of capillary rise of the fluids is measured 24 hours later, when it is assumed that they have reached equilibrium. Knowing that the contact angle for ethanol is zero, assuming $r$ and $g$ have been to be the same in both soil columns and substituting known values for the fluid properties of water and ethanol simplifies the capillary rise equation such that the apparent contact angle can now be calculated from

$$
\cos \theta_{w}=0.369 h_{w} / h_{\theta}
$$

where $\quad h_{w}$ and $h_{e} \quad=$ the heights of rise of water and ethanol, respectively, and

$$
\theta_{w} \quad=\text { the apparent advancing contact angle for water. }
$$

\subsubsection{Surface tension of the fluid}

Resistance to wetting can be overcome by reducing the surface tension of the fluid. The wettability of a soil thus can be characterised by its so-called critical surface tension (CST) which is the highest surface tension to readily wet the soil (Watson and Letey, 1970). The same method has been termed the molarity of ethanol droplet (MED) test when the molarity of the aqueous ethanol drop rather than its surface tension is recorded (King, 1981). 


\subsubsection{Sorptivity Index}

More recently, Tillman et al. (1989) developed a technique for describing water repellency in terms of the intrinsic sorptivity of the soil. This method is appropriate for soils with "subcritical levels of repellency", which might not be particularly noticeable normally (Tillman et al., 1989). Apart from the fact that I had not found a reference to this method until after most of the soil testing had been completed, the soils tested in my studies probably had repellency levels which were too extreme for its use to be appropriate.

\subsubsection{Sampling of Soils}

Soil samples were taken from several forestry sites around South Africa. These sites represented most of the major timber-producing soils. At each location a sample was taken from the top $50 \mathrm{~mm}$ of mineral soil under each of the locally predominant plantation tree types as well as grassland or other indigenous vegetation. In the case of plantations, the chosen sites had supported that tree type for at least twenty years. In South Africa the predominant plantation trees are eucalypts (mostly Eucalyptus grandis), pines (Pinus patula, Pinus radiata, Pinus elliottii and Pinus taeda) and black wattle (Acacia mearnsii). The actual pine species grown depends on the geographical location - within any one region there is relatively little variation in species.

At each location, under as many vegetation types as were represented, soil samples were collected as near to each other as possible, so as to reduce the variability in soil properties which was not due to the vegetation supported by that soil. The origin, parent material, organic carbon and texture of the sampled soils are summarised in Table 9.1. The geographic locations of the sample sites are shown in Figure 9.1.

In the laboratory, the soil samples were sieved through a $2 \mathrm{~mm}$ sieve and air-dried. They were then subjected to three soil wettability tests described by DeBano (1981) and a fourth test proposed by King (1981).

(1) Water drop penetration time (WDPT) is the time (here measured in seconds to a maximum of 300 ) which a water drop takes to be absorbed into a smooth surface of the soil. 
Table 9.1 The origin and some properties of a range of soils from forestry regions in South Africa. The mean value of organic carbon is shown with its standard error in brackets. The location codes cross-refer to Figure 9.1 and the text.

\begin{tabular}{|c|c|c|c|c|c|}
\hline $\begin{array}{l}\text { Location } \\
\text { code }\end{array}$ & Location & Geology & (\%) & Texture class & $\begin{array}{l}\text { Specific surface } \\
\left(\mathrm{m}^{2} \mathrm{~g}^{-1}\right)\end{array}$ \\
\hline 1. $M M$ & $\begin{array}{l}\text { MacMac S.F.* } \\
\text { E. Tvl }\end{array}$ & $\begin{array}{l}\text { Lyttleton } \\
\text { Dolomite }\end{array}$ & $\begin{array}{l}11.2 \\
(2.1)\end{array}$ & silty clay loam & 4.92 \\
\hline 2. Cey & $\begin{array}{l}\text { Ceylon S.F. } \\
\text { E. Tvl }\end{array}$ & $\begin{array}{l}\text { Timeball Hill } \\
\text { Shale }\end{array}$ & $\begin{array}{c}4.0 \\
(0.7)\end{array}$ & silty clay loam & 7.08 \\
\hline 3. $\mathrm{Bv}$ & $\begin{array}{l}\text { Berguliet S.F. } \\
\text { E. Tvl }\end{array}$ & $\begin{array}{l}\text { Nelspruit } \\
\text { Granites }\end{array}$ & $\begin{array}{c}7.5 \\
(2.6)\end{array}$ & loam & 2.45 \\
\hline 4. $\mathrm{CP}$ & $\begin{array}{l}\text { Cathedral Peak } \\
\text { Natal Drakensberg }\end{array}$ & $\begin{array}{l}\text { Beaufort } \\
\text { Shale }\end{array}$ & $\begin{array}{c}7.8 \\
(1.1)\end{array}$ & silty clay loam & 6.16 \\
\hline 5. $\mathrm{Nt}$ & $\begin{array}{l}\text { Ntabamhlope } \\
\text { Natal Drakensberg }\end{array}$ & $\begin{array}{l}\text { Beaufort } \\
\text { Shale }\end{array}$ & $\begin{array}{c}6.2 \\
(2.2)\end{array}$ & silty clay & 8.39 \\
\hline 6. $\mathrm{RD}$ & $\begin{array}{l}\text { Richmond } \\
\text { Natal Midlands }\end{array}$ & $\begin{array}{l}\text { Ecca } \\
\text { Shale }\end{array}$ & $\begin{array}{l}10.0 \\
(1.2)\end{array}$ & silty clay & 9.30 \\
\hline 7. WH & $\begin{array}{l}\text { Windy Hill } \\
\text { Natal Midlands }\end{array}$ & $\begin{array}{l}\text { Table Mountain } \\
\text { Sandstone (TMS) }\end{array}$ & $\begin{array}{c}6.2 \\
(1.8)\end{array}$ & loam & 3.95 \\
\hline 8. ZC & $\begin{array}{l}\text { KwaMbonambi } \\
\text { Zululand Coast }\end{array}$ & $\begin{array}{l}\text { Quaternary } \\
\text { Sands }\end{array}$ & $\begin{array}{c}1.2 \\
(0.03\end{array}$ & loamy sand & 0.76 \\
\hline 9. JK & $\begin{array}{l}\text { Jonkershoek } \\
\text { S.W. Cape }\end{array}$ & $\begin{array}{l}\text { Cape } \\
\text { Granite }\end{array}$ & $\begin{array}{c}6.3 \\
(1.4)\end{array}$ & silty loam & 1.70 \\
\hline 10. Sd & $\begin{array}{l}\text { Saasveld } \\
\text { Southern Cape }\end{array}$ & $\begin{array}{l}\text { TMS and } \\
\text { Saasveld schist }\end{array}$ & $\begin{array}{c}6.8 \\
(2.0)\end{array}$ & loam & 3.00 \\
\hline
\end{tabular}

† Estimated from the particle size distribution by a formula given by Hillel (1980)

* S.F. = State Forest $\quad$ E. Tvl = Eastern Transvaal

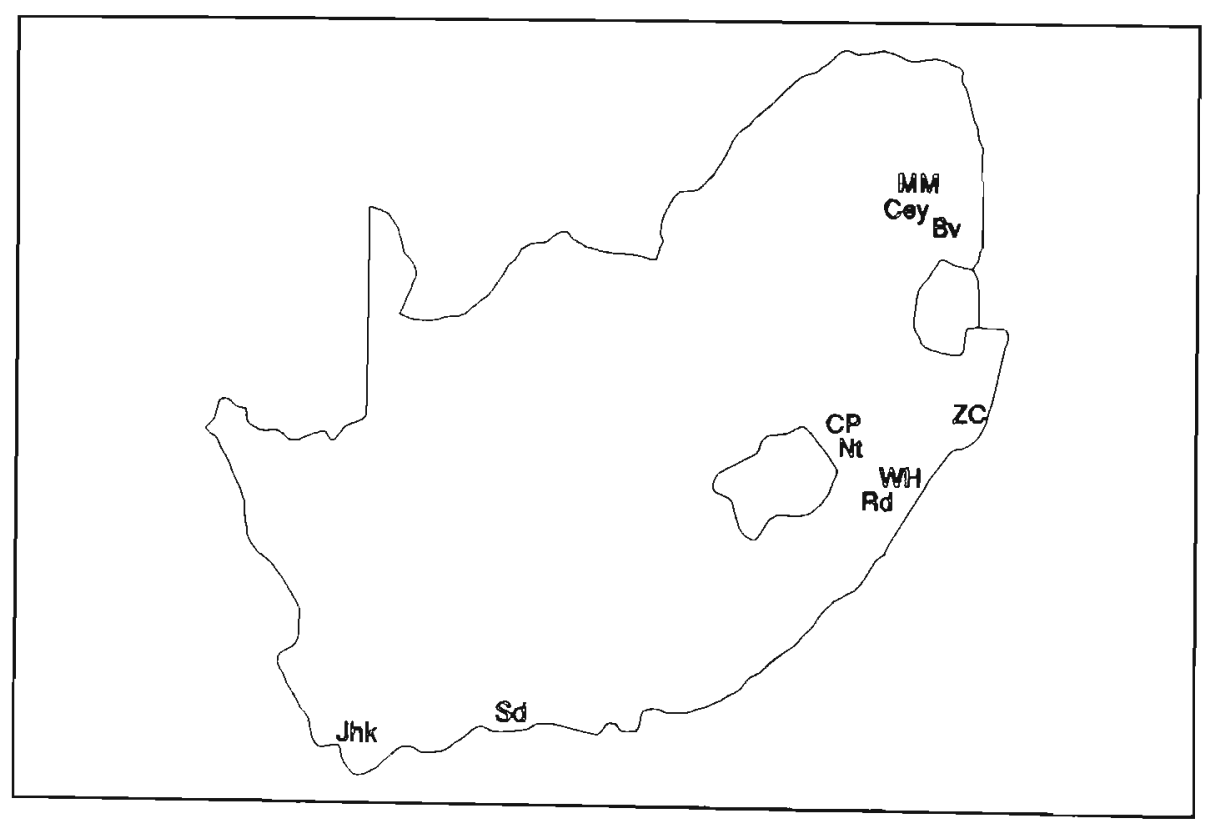

Figure 9.1 The approximate locations of the forestry sites in South Africa from which soils were sampled for repellency testing. The location codes cross-refer to Table 9.1 and the text. 
(2) The critical surface tension (CST) is the highest surface tension $\left(\mathrm{N} \mathrm{m}^{-1}\right)$ which readily wets the soil. This is measured using a range of aqueous ethanol solutions of varying molarity and hence surface tensions (completely wettable soil will be readily wet at zero molarity of ethanol). Ready wetting was defined as a penetration time of one second.

(3) Apparent advancing soil-to-water contact angle (ACA) was measured using the equilibrium capillary rise test (Section 9.1.2.2). Glass columns, $500 \mathrm{~mm}$ long with an inside diameter of $25 \mathrm{~mm}$, were coated with a thin film of paraffin wax to make the glass water repellent. Detailed but unreplicated measurements of the rate of capillary rise of water measurements were taken, as these data give a good indication of the effects of water repellency in a soil.

(4) An infiltration index (IR; King, 1981) was determined on the dry soil using a miniature ring infiltrometer. The ring was made from perspex tube with an inside diameter of $25 \mathrm{~mm}$, with the lower end of the ring was sharpened so as to displace the soil outwards. The ring was pushed $10 \mathrm{~mm}$ into the soil surface and a measured depth of water $(5 \mathrm{or} 10 \mathrm{~mm})$ was added. The depth of water absorbed (to a minimum of $5 \mathrm{~mm}$ ) was divided by the time taken for its absorption (to a maximum of 15 minutes, giving a minimum index of $5 / 900 \mathrm{~mm} \mathrm{~s}^{-1}$ ). The greater depth of water $(10 \mathrm{~mm})$ was used where the sample was known to be wettable. In terms of what it measures this test is much the same as WDPT.

Tests 1, 2 and 4 were performed three times on sub-samples of each soil, but the capillary rise tests were performed only once for each soil, of which a large enough sample was available. For tests 1 , 2 and 4 soil samples were placed in small bowls and the surface smoothed by gently patting it with the bottom of a glass beaker to reduce the gross roughness of the surface. The range of tests used provide complementary information on soil wettability.

\subsection{RESULTS OF THE WETTABILITY TESTS}

\subsubsection{Correlations Between Variables}

The correlations between the different measures of repellency in soils (the dependent variables) and between these measures of repellency and some possible predictor variables is of interest (Table 9.2) as surveys of this scope are seldom undertaken. Good, though not perfect, correlations were obtained between the different measures of repellency, indicating that while all methods may show a soil to be repellent each method often highlights a different aspect of the soil's response to wetting. The repellency index (RI) is the quotient of WDPT and CST, and apparent contact angle is derived from the height of capillary rise of water, hence the high correlations within these groups of variables is not notable. 
Table 9.2 Pearson correlation coefficients $(\rho)$ for a range of measures of water repellency and some potential predictor variables for a sample of South African forestry soils.

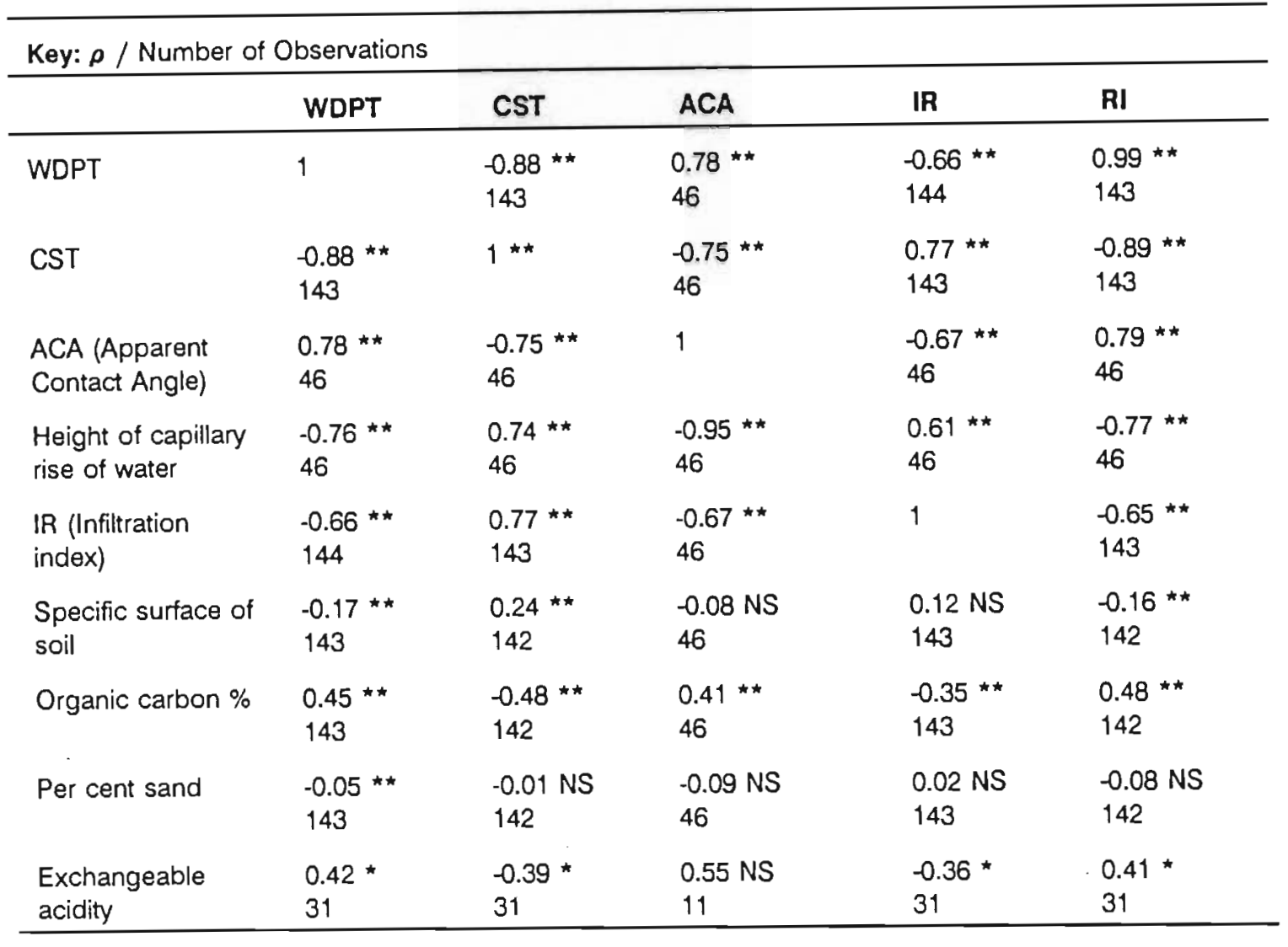

$\mathrm{RI}=$ repellency index;

${ }^{*},{ }^{* *}$ and NS denote significance levels (under Ho: $\rho=0$ ) $a<0.01,0.1$ and $a>0.1$ respectively.

Based on the hypothesis that repellency is the result of a coating on the soil particles of a hydrophobic organic substance, soil with a low specific surface (coarse texture) is expected to have a greater likelihood of being repellent. In my sample of soils this relationship is very weak; the negative correlation between surface area and repellency is close to zero even in those cases where it is significant (Table 9.2). The percentage of sand in a soil though had no bearing on the repellency rating. In short, it was found that soils of any texture could be water repellent. The level of organic carbon and exchangeable acidity were positively related to the repellency rating, displaying significant correlations with all measures of repellency (Table 9.2). It is not clear whether there is any functional relationship between repellency and exchangeable acidity; the high correlation could simply be an artefact of a high correlation between organic carbon and exchangeable acidity in my samples. 


\subsubsection{Analysis of Variance}

Analysis of variance of water repellency was performed using the GLM procedure of the SAS statistical package (SAS Institute, 1985) which is appropriate for unbalanced designs. Analysis was performed on the dependent variables CST, IR and ACA. WDPT scores provide little discrimination amongst all non-wettable soils and hence this variable has a very skewed distribution. The results of the analyses are shown in Table 9.3. Sources of variation, other than the main effects of vegetation and location, are only included in the table of results where they were significant. There was no significant interaction between location (or lithology) and vegetation, so main effects were tested with the residual of the full model. Different results were obtained with the different measures of repellency (Table 9.3).

Table 9.3 The results of the analysis of variance of three measures of water repellency of a sample of South African forestry soils.

\begin{tabular}{|c|c|c|c|c|c|}
\hline $\begin{array}{l}\text { Dependent } \\
\text { variable }\end{array}$ & Source of variation & $d f$ & SS & $\begin{array}{l}\text { Mean } \\
\text { square }\end{array}$ & $\mathbf{F}$ \\
\hline Critical & Locations & 10 & 5047 & 505 & $5.7^{\star \star}$ \\
\hline surface & Vegetation (treatments) & 5 & 7214 & 1443 & $16.2^{\star \star}$ \\
\hline \multirow[t]{4}{*}{ tension } & $\begin{array}{l}\text { Sampling within experimental } \\
\text { units }\end{array}$ & 77 & 2139 & 28 & $0.3 \mathrm{NS}$ \\
\hline & Organic carbon & 1 & 1352 & 1352 & 15.2 ** \\
\hline & Surface area & 1 & 1170 & 1170 & 13.2 * \\
\hline & Residual error & 19 & 1688 & 89 & \\
\hline \multirow{5}{*}{$\begin{array}{l}\text { Infiltration } \\
\text { index }\end{array}$} & Locations & 10 & 6.6 & 0.6 & $7.5^{\star \star}$ \\
\hline & Vegetation (treatments) & 5 & 3.6 & 0.9 & $10.8^{\star \star}$ \\
\hline & $\begin{array}{l}\text { Sampling within experimental } \\
\text { units }\end{array}$ & 81 & 3.6 & 0.1 & $0.6 \mathrm{NS}$ \\
\hline & Organic carbon & 1 & 1.0 & 1.0 & 11.7 ** \\
\hline & Residual error & 32 & 2.7 & 0.1 & \\
\hline \multirow{3}{*}{$\begin{array}{l}\text { Apparent } \\
\text { contact angle }\end{array}$} & Locations & 10 & 388 & 38.8 & $t$ \\
\hline & Vegetation (treatments) & 5 & 606 & 121.2 & 2.66 * \\
\hline & Residual error & 6 & 1002 & 45.6 & \\
\hline
\end{tabular}

† Test not valid without sampling; ${ }^{*}=(a>\mathrm{F})<0.05 ;{ }^{\star \star}=(a>\mathrm{F})<0.01 ; \mathrm{NS}=$ not significant.

In all models there was a large portion of unexplained variance. For all models (all dependent variables) vegetation type explained most variance and this was a significant effect in all models. Without replication of the ACA measures the test of location effects was not valid. For both CST and IR, location (which generally related to the geological type) was a secondary but significant effect. Replication was not a significant source of 
variation; in other words, the same vegetation type on the same lithology produced a similar repellency in the soil.

\subsubsection{The Effect of Vegetation Type}

The results from eight of the sample locations which included a eucalypt plantation and at least one other plantation tree type, show that in virtually all areas, as determined by different tests, soils under eucalypts were most repellent (Figure 9.2). Critical surface tension values (Figure 9.2a) above $0.065 \mathrm{~N} \mathrm{~m}^{-1}$ would indicate a wettable soil, while values less than $0.045 \mathrm{~N} \mathrm{~m}^{-1}$ indicate a repellent soil. By this classification grassland soils at three locations, MM, WH and ZC, two of which had sandy soils, were somewhat repellent. By contrast, eucalypt soil at only one location, Cey, was wettable, and at two others, Rd and $\mathrm{ZC}$, the soils were somewhat repellent.

A similar pattern emerges from the results of the other tests. At only one location, Cey, did eucalypt soil have a reasonable infiltration index (Figure 9.2b), and even this was much lower than the same soil beneath grassland. Except for one test, eucalypt soils had the highest apparent contact angles, which relates to the very low or negative capillary rise in the eucalypt soils (Figures $9.2 \mathrm{c}$ and 9.2d). A generalised ranking of the repellency developed under different vegetation types would be that grassland soils are wettable, pine soils are somewhat repellent, wattle soils vary from somewhat repellent to repellent, and eucalypt soils are repellent.

If the results are averaged by vegetation type (Figure 9.3), a similar pattern emerges. Here the indigenous forest soils that were sampled from the Zululand coast and the Saasveld area of the Southern Cape Province are included. The forest soils, together with the soils from wattle plantations, are the next most repellent after the eucalypt soils. The forest soils were fairly coarse-textured in the main, and their litter build-up had developed undisturbed for many years (longer than any of the other vegetation types). 


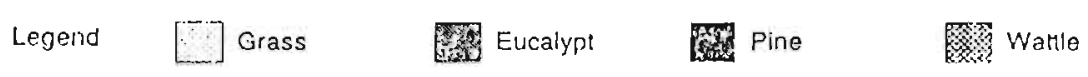
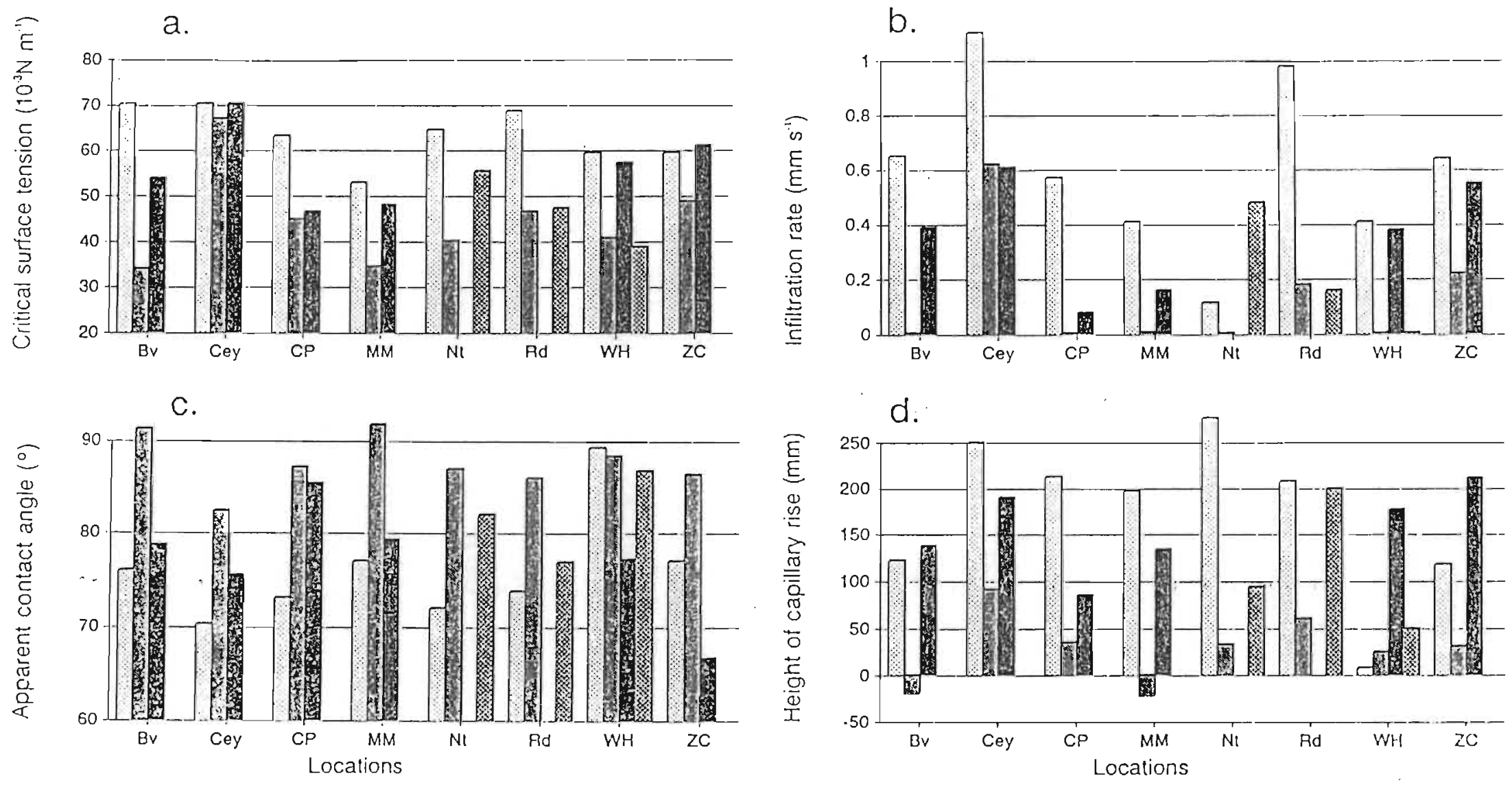

Figure 9.2

The results of four different measures of water repellency in soils from beneath four vegetation types from the forestry regions of South Africa. High values of critical surface tension (a), infiltration index (b) and height of capillary rise after 24 hours (c), and low values of apparent contact angle (d) indicate weaker repellency. (Note that only a subset of the vegetation types grow at each location.) 


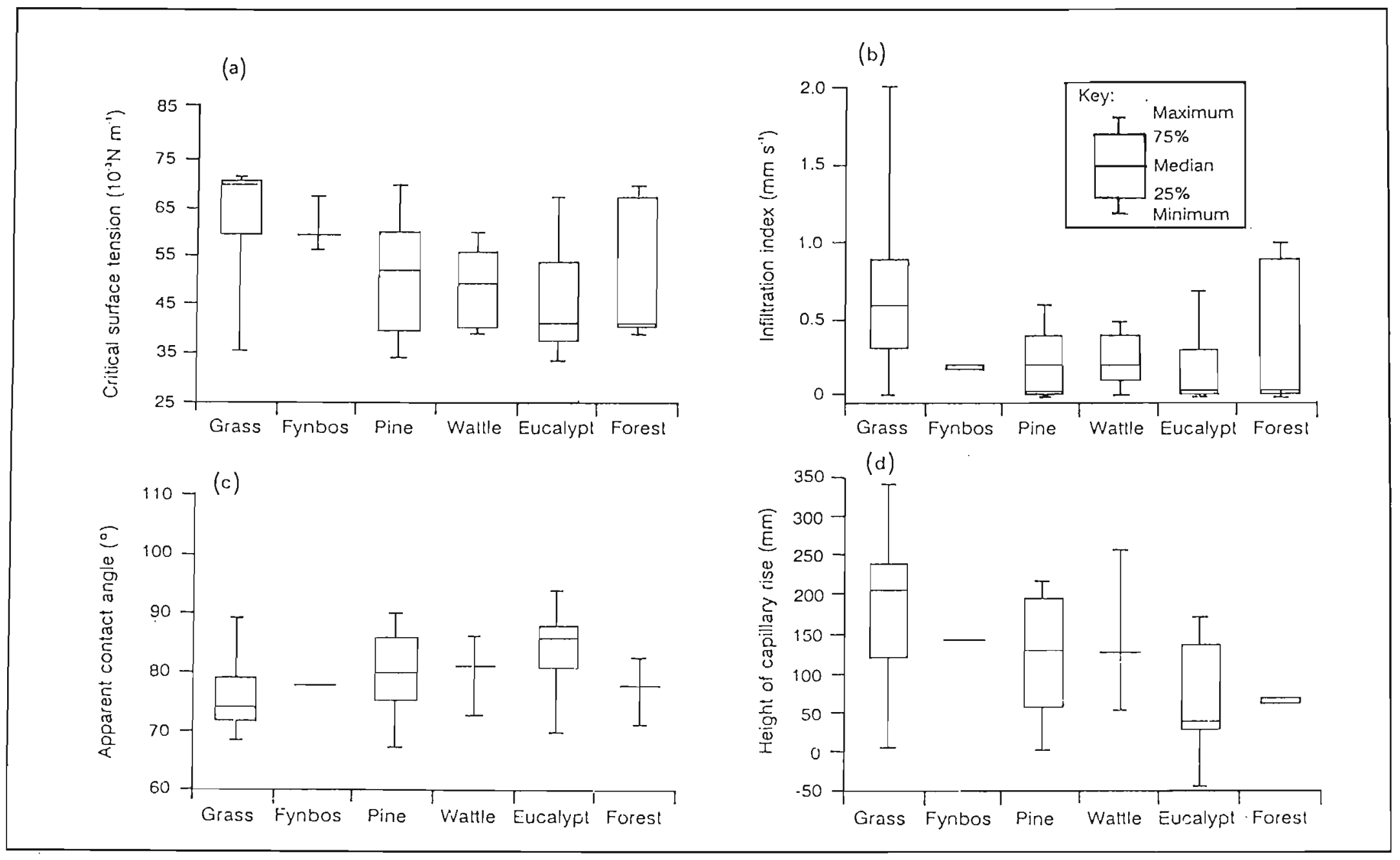

Figure 9.3 The effect of vegetation type on four measures of soil wettability averaged over all sample locations at which soils beneath the vegetation type were sampled. 
The responses of soils from fynbos sites in the Western and Southern Cape are closest to the grassland soils in being least repellent, and they also share the characteristic of being more regularly burned. This regular removal of plant litter may in part explain the weak development of water repellency. The one grassland soil which had moderate to strong repellency was from the Windy Hill (WH) site. This particular soil was coarsetextured and from a fire-refuge site (subject to little burning), allowing a build-up of plant litter over many years.

Typical of the effect of water repellent soil on soil water movement is the resistance to capillary rise. Amongst other things capillary rise is dependent on the contact angle between the soil and water. Where this angle is very high, capillary rise will be restricted. The capillary rise curves for similar soils under different vegetation types (Figure 9.4) illustrate this effect of contact angle. Actual capillary rise occurs only once water has risen above the level of the water in which the columns are standing. At both sites, Cathedral Peak (a) and Windy Hill near Wartburg (b), therefore, no real capillary rise took place in the eucalypt soils. Despite the positive head, penetration of water into the soil columns did not reach the level of the head over the two days of measurement. This resistance of water entry into the soil columns was typical of the eucalypt soils. The capillary rise in pine soil samples was also depressed below that of grassland, but to a lesser degree.

\subsubsection{The Effect of Soil Texture}

It is apparent from the correlations in Table 9.2 that soil texture does not determine repellency. Some fine-textured soils, such as the silty clay loam from MM and the silty clay at Rd (Table 9.1), were highly repellent (Figure 9.2). The silty clay loam from shales at Cey though showed no tendency to repellency. There was a tendency though for sandy soils beneath grass to show greater repellency that heavier soils beneath grass, e.g. WH and $\mathbf{Z C}$ versus $\mathbf{N t}$ and $\mathrm{Rd}$ (Figure 9.2). 
o. Cothedral Peak - sandy loam

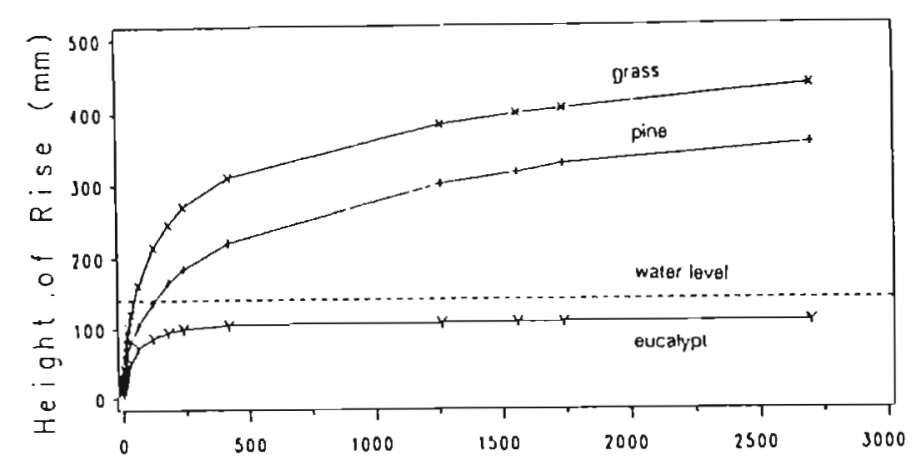

b. Windy Hill - loomy sand

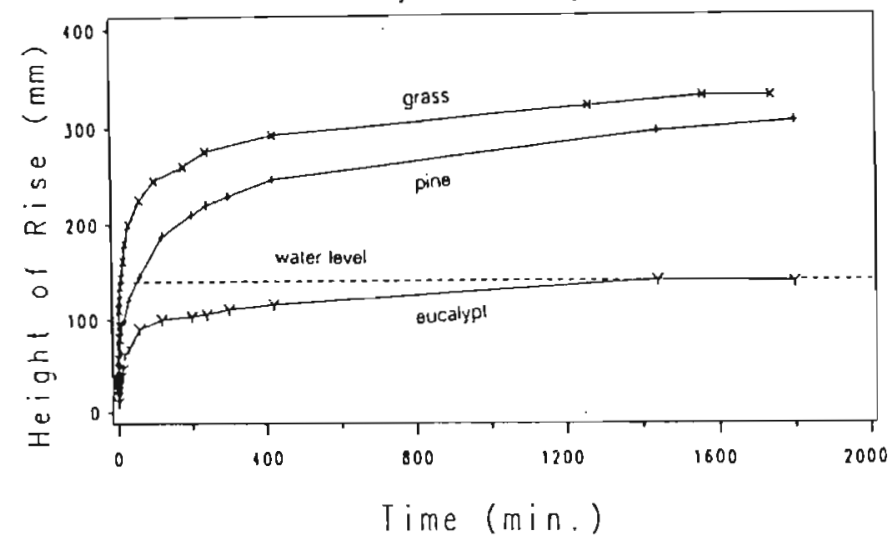

Figure 9.4 Time plots of the height of rise of water up columns of soil from two locations in Natal - (a) Cathedral Peak and (b) Windy Hill near Wartburg.

\subsubsection{Predicting the Risk of Repellency in Soil}

Apart from the strong influence of vegetation type, it is likely to be difficult to predict the probability of a particular soil being water repellent. Using the results of the above study and subjective judgement based on experience, I have produced a preliminary decisiontree (Table 9.4) which yields a risk of water repellency occurring in any South African forestry soil. This is not intended as a quantitative model, for which it is felt there is inadequate information at present, but rather as a means of conveying existing knowledge in a useful form for the field manager. 
Table 9.4 A preliminary decision-tree to estimate the probability of any particular forest soil in South Africa being or becoming water repellent.

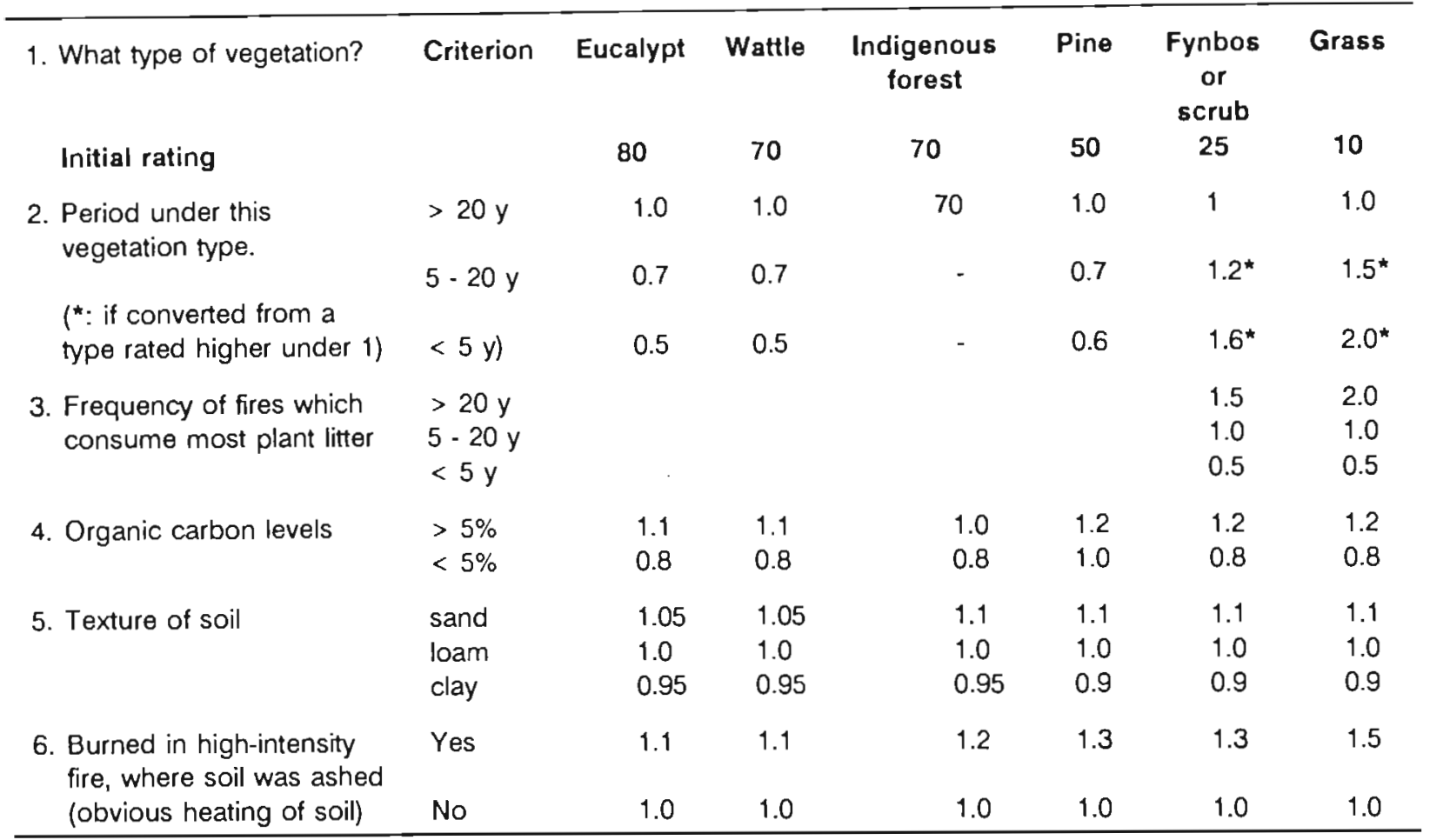

Key: Enter table by answering question 1. Modify initial rating obtained from this question by multiplying successively by the factors obtained in answer to subsequent questions in the table. If answer square is blank proceed to next question. Result is the probability $(\%)$ of serious repellency in dry soils. For example, the probability rating for an unburnt clay soil (with an organic carbon content in the topsoil of $6 \%$ ) from beneath a young pine plantation (10 years old) which previously supported grassland would be $50 \times 0.7 \times 1.2 \times 0.9 \times 1.0=37.8 \%$.

\subsection{DISCUSSION}

The results indicate that water repellent soils are a common feature of South African forestry soils, at least when in the dry state. Because repellency is more pronounced when a soil is dry, its presence may not always be noticeable in the field. Also, it is unlikely that water repellency will occur in a continuous layer in the soil. I have observed that there are usually frequent preferred points where repellency is poorly developed or absent, where infiltration and percolation can occur at high rates. Such points may be alongside rocks, disturbed soil, old root channels or other macropores. Consequently, subsoils may appear to be normally wetted after a rainstorm, while overlying soils are unexpectedly dry.

Channelling of water to preferred pathways as a result of water repellent soils may not lead to surface wash or erosion when there is a reasonable ground cover of plant litter or where the slope is gentle. Ground cover provides added opportunities for rain water to be 
detained and retained at the point where it falls, reduces the velocity of any surface flow that may develop, and can trap soil which is eroded by rainfall and overland flow.

It can be hypothesised that water repellency in the surface soils, especially in the extreme state as observed in soils under eucalypts, may channel water to preferred paths for rapid and deep percolation. Deep in the soil profile, below depths normally classed as agricultural soil, large and deep-rooting trees can exploit the water which is not available to shallowly rooting plants. Allison and Hughes (1983) found, with the aid of tracers (stable isotopes of oxygen and hydrogen), that rain on eucalypt savanna in semi-arid South Australia percolated to depths of at least $12 \mathrm{~m}$ below the surface, whilst that on adjacent agricultural lands planted to cereals with much lower water use characteristics, had not penetrated more than $2.5 \mathrm{~m}$ in the same time (17 years). The authors suggest that eucalypts channelled water into root channels which acted as macropores for water transport to the water table.

A similar situation has been observed in an experimental eucalypt planting near Greytown in the Natal midlands, South Africa. A neutron moisture meter was used to follow the advance of wetting fronts below ponded water into dry soil. In addition to the slow and gradual wetting from the surface that would have been expected, there was a simultaneous and rapid increase in wetness at the bottom of the profile (Boden, 1992). In this case the author suggests that large cracks in the soil profile, caused by the desiccating effect of the eucalypt plantation, provided the channels for the rapid transport of water.

Revegetation of sites previously supporting eucalypts may be difficult because of the persistence of water repellency in the soil. Delayed revegetation would leave the site exposed to erosion for longer. There are indications that this has been the case on certain sites cleared of eucalypt vegetation on Table Mountain in the Cape Province of South Africa (personal observation).

Research on water repellent soils in California has shown that surfactants can successfully remove the resistance to wetting of water repellent soils, and thereby improve seedling germination and growth, and reduce erosion (Osborn et al., 1964). Such treatments were not cost-effective on a large scale because of the cost of their application (aerial spraying) and their temporary effect, whereafter repellency dominated again. An alternative measure is to break up the repellent layer of soil and mix it with underlying soil. This effectively 
removes the barrier to water penetration, but is also an expensive option, and will probably not be a practical solution except for productive arable land or on sites of special value. Farmers in South Australia have reduced the effects of repellency by tilling the soil during or just after rains (King, 1974, cited by DeBano, 1981). On Devils Peak, in Cape Town, contour ditches dug to bury the bottom end of a wind-break made of shade-cloth provided an ideal entry point for surface water shed by the water repelling slopes immediately above them.

\subsection{CONCLUSIONS}

Eucalypts, wattle and indigenous forest in general, relative to other vegetation types in South Africa, induce a high level of water repellency in the soil beneath them. This is true for the range of soils sampled, and appears to occur in all the major timber production areas in South Africa. Because repellency is more pronounced when a soil is dry, its presence may not always be noticeable in the field. Also, surface storage of rain water in the plant litter on the forest floor may disguise the fact that infiltration and percolation are impeded. Consequently water repellent soil may not be a problem until canopy and ground cover are removed during clear-felling, or as a result of a fire. Once surface storage capacity is removed and the soil is exposed to drying, the site is at risk of overland flow occurring during rainstorms, leading to soil erosion and reduced soil water replenishment.

In this chapter it has been shown that water repellency is a common feature of, particularly, eucalypt and wattle plantation soils in South Africa. This is the case without the contribution of heating of soils during fires. This sets these sites apart as having a high risk for overland flow and soil erosion in situations where the sites are cleared of ground cover. It would seem that the soils beneath pine plantations have a greater potential to change to extreme repellency following fire than the other plantation types, the soils of which already show high levels of water repellency in the dry state.

In the next chapter the results of an experiment using a rainfall simulator to study the hydrological effects of fire on small plots are reported. In this study the role of water repellent soils, with and without the influence of fire and ground litter, is highlighted. 


\section{CHAPTER 10}

\section{RAINFALL SIMULATOR STUDY}

In an attempt to replicate the fire effects observed in catchment studies, a series of rainfall simulator trials were run. In this experiment two burn treatments and one hand clearing treatment were applied to three of four plots. It was expected that the burns would induce water repellency in the soils and this would result in greater overland flow and soil loss from these plots. The rainfall simulator trials were conducted in the Natal midlands, a major timber producing zone in the summer-rainfall region.

\subsection{STUDY DESIGN}

\subsubsection{The Rainfall Simulator}

The rotating-boom rainfall simulator used in this experiment is a well-known tool in agricultural research. The simulator used is essentially the same as that described by Swanson (1965), for which McPhee et al. (1983) give technical specifications and justify its use for soil loss studies in South Africa. The simulator consists of ten horizontal, rotating booms radiating outwards from a central manifold which is supplied with water by means of a vertical standpipe. On each boom $1 / 2$ U80100 vee-jet spray nozzles, which were developed to provide a water drop size distribution closely approximating that of natural rainfall in the eastern USA, are fitted to a design which ensures the most even distribution of water possible (McPhee et al., 1983). However, because of the cyclic nature of the rainfall application rates and the long cycle time, the apparatus is not strictly suitable for infiltration studies (McPhee et al., 1983). Simulated rainfall is sprayed over a circular area of $8.4 \mathrm{~m}$ radius and area of $223.8 \mathrm{~m}^{2}$. The rainfall simulator is calibrated to simulate rainfall at $63 \mathrm{~mm} \mathrm{~h}^{-1}$.

Four small plots $(10.6 \times 1.8 \mathrm{~m})$ are laid out beneath the simulator, lengthwise down the slope with a sill plate and attached collection chute installed on the lower end. 


\subsubsection{Experimental Layout}

At each of three locations, each of which was a long-established but recently felled timber plantation in the Natal midlands, two replicate sites of gentle slope $(\sim 10 \%)$ and easy access to roads and water were selected. One location was an old black wattle (Acacia mearnsii) plantation and the other two both eucalypt (Eucalyptus grandis) plantations. The characteristics of the locations are summarised in Table 10.1. At each replicate four plots were prepared, each for a single treatment. Two plots in each site were loaded with logging slash, but for practical reasons these plots were always the outer two of the four plots. One of these slash piles was chosen, at random, to be kept dry so as to cause greater soil heating upon burning. This slash plot was covered with plastic sheeting and the other left exposed. One of the remaining plots was cleared by hand of all undecomposed surface litter (to mimic a "bare fallow" treatment), and the remaining plot left as a control with its typical forestry ground cover of plant litter. Once prepared, all traffic was kept out of the plots so as not to disturb the soil surface.

Table 10.1 Site and soil characteristics of the three locations used in the rainfall simulator study of fire effects. (Standard deviations, where available, in brackets)

\begin{tabular}{|c|c|c|c|c|c|c|c|c|}
\hline Name & Location & Vegetation & $\begin{array}{l}\text { Soll } \\
\text { texture }\end{array}$ & $\begin{array}{l}\text { Topsoil } \\
\text { bulk } \\
\text { density } \\
\left(\mathrm{kg} \mathrm{m}^{-3}\right)\end{array}$ & $\begin{array}{l}\text { Organic } \\
\text { carbon } \\
(\%)\end{array}$ & $\begin{array}{l}\text { Repellency } \\
\text { rating of } \\
\text { topsoils }\end{array}$ & $\begin{array}{l}\text { Pre-fire } \\
\text { fuel } \\
\text { wetness } \\
(\%)\end{array}$ & $\begin{array}{l}\text { Pre-fire } \\
\text { soil } \\
\text { wetness } \\
(\%)\end{array}$ \\
\hline Wattle $(M)$ & $\begin{array}{l}\text { Richmond } \\
\text { Natal }\end{array}$ & $\begin{array}{l}\text { Acacia } \\
\text { meamsii } \\
\text { plantation }\end{array}$ & $\begin{array}{l}\text { silty } \\
\text { clay }\end{array}$ & 642 & 13.5 & repellent & 17 & $\begin{array}{l}54 \\
(3.2)\end{array}$ \\
\hline $\begin{array}{l}\text { Eucalypt } 1 \\
\text { (E1) }\end{array}$ & $\begin{array}{l}\text { Richmond } \\
\text { Natal }\end{array}$ & $\begin{array}{l}\text { Eucalyptus } \\
\text { grandis } \\
\text { plantation }\end{array}$ & $\begin{array}{l}\text { silty } \\
\text { clay }\end{array}$ & 739 & 13.9 & repellent & - & $\begin{array}{l}88 \\
(27)\end{array}$ \\
\hline $\begin{array}{l}\text { Eucalypt } 2 \\
\text { (E2) }\end{array}$ & $\begin{array}{l}\text { Mid-lliovo } \\
\text { Natal }\end{array}$ & $\begin{array}{l}\text { Eucalyptus } \\
\text { grandis } \\
\text { plantation }\end{array}$ & $\begin{array}{l}\text { sandy } \\
\text { loam }\end{array}$ & 1190 & 3.8 & wettable & $\begin{array}{l}14 \\
(4.8)\end{array}$ & $\begin{array}{l}25 \\
(6.4)\end{array}$ \\
\hline
\end{tabular}

The plots were selected and prepared in July and August 1989, and the burn plots burned in January 1990. The overland flow plots were prepared immediately after the burns and the rainfall simulations performed in January and February 1990.

At each site two one-hour simulated rain storms, separated by a 24-hour period, were applied to the prepared plots. A storm was stopped short of an hour if steady overland 
flow rates were achieved in all four plots before this time. Details of the storms applied at each site are given in Table 10.2.

Table 10.2 Details of the simulated rain storms at each of two sites (replicates) at three forestry locations in the Natal Midlands.

\begin{tabular}{|c|c|c|c|c|c|c|}
\hline Location & Replicate & $\begin{array}{l}\text { Mean site } \\
\text { slope (\%) }\end{array}$ & $\begin{array}{l}\text { Storm number } \\
\text { (i.e. run) }\end{array}$ & $\begin{array}{l}\text { Duration } \\
\text { (minutes) }\end{array}$ & $\begin{array}{c}\text { Storm } \\
\text { depth }(\mathrm{mm})\end{array}$ & $\begin{array}{c}\text { Mean rainfall } \\
\text { intensity }\left(\mathrm{mm} \mathrm{h}^{-1}\right)\end{array}$ \\
\hline \multirow{4}{*}{$w$} & 1 & 8.4 & 1 & 60 & 56 & 56 \\
\hline & & & 2 & 46 & 37 & 49 \\
\hline & 2 & 11.0 & 1 & 60 & 61 & 61 \\
\hline & & & 2 & 60 & 56 & 56 \\
\hline \multirow{4}{*}{ E1 } & 1 & 9.8 & 1 & 54 & 50 & 55 \\
\hline & & & 2 & 54 & 38 & 42 \\
\hline & 2 & 9.3 & 1 & 60 & 50 & 50 \\
\hline & & & 2 & 46 & 46 & 58 \\
\hline \multirow{4}{*}{ E2 } & 1 & 11.2 & 1 & 60 & $71^{*}$ & $57 \dagger$ \\
\hline & & & 2 & 60 & 56 & 56 \\
\hline & 2 & 10.0 & 1 & 60 & 56 & 56 \\
\hline & & & 2 & 60 & 58 & 58 \\
\hline
\end{tabular}

* includes natural rainfall during simulation, hence $\quad$ indicates weighted mean intensity over the hour.

The flow rate off each plot was measured and water samples taken at the chute at regular (four minute) intervals during simulated storms. From these measurements the overland flow was calculated as a volume and proportion of rainfall, and soil loss calculated from flow rate and sediment loads in the water samples. The field and calculation procedures followed were those recommended by the Division of Agricultural Engineering of the South African Department of Agriculture and Fisheries.

\subsubsection{Application of treatments}

The effort to effect different burns to the two slash pile plots in each replication was an uncertain success. The plastic sheets decayed and shredded in the wind to some extent. Mean soil wetness beneath the slash piles before burning was not significantly different between the two treatments. After burning the Richmond eucalypt site (E1) the fire crept into the soil at the first replicate and the control and bare plots were partially burnt in this way.

The temperature of the soil at different depths in the soil beneath one of the covered slash piles at this Richmond eucalypt site (E1) during the burn was recorded using three 
thermocouple probes connected to an electronic data logger. These measurements are plotted in Figure 10.1 for the full period of measurement. It can be seen that despite the effort to protect the slash pile from rain, soil temperatures did not exceed $130^{\circ} \mathrm{C}$ and consequently impacts on the soil at this site (E1, replicate 1) were not particularly notable.

The temperature over time plot (Figure 10.1) shows the initial rapid rise in soil temperatures at all depths which occurred during the active flaming phase of the slash pile burn. It is clear that heat penetration is lagged and peak temperatures damped at greater depths. During a smouldering burn phase, roughly from $13: 30$ to $14: 30$, the soil temperature at 5 $\mathrm{mm}$ depth was already cooling while at 15 and $25 \mathrm{~mm}$ temperatures continued to increase. Shortly before 15:00 a warm breeze fanned the smouldering fire and caused it to flare (resumed active flaming) for a little over half an hour. This caused temperatures near the surface to rise slowly again until a point when all water in the soil had been driven off, causing a dramatic rise is temperature at $5 \mathrm{~mm}$ depth followed by at rapid fall.

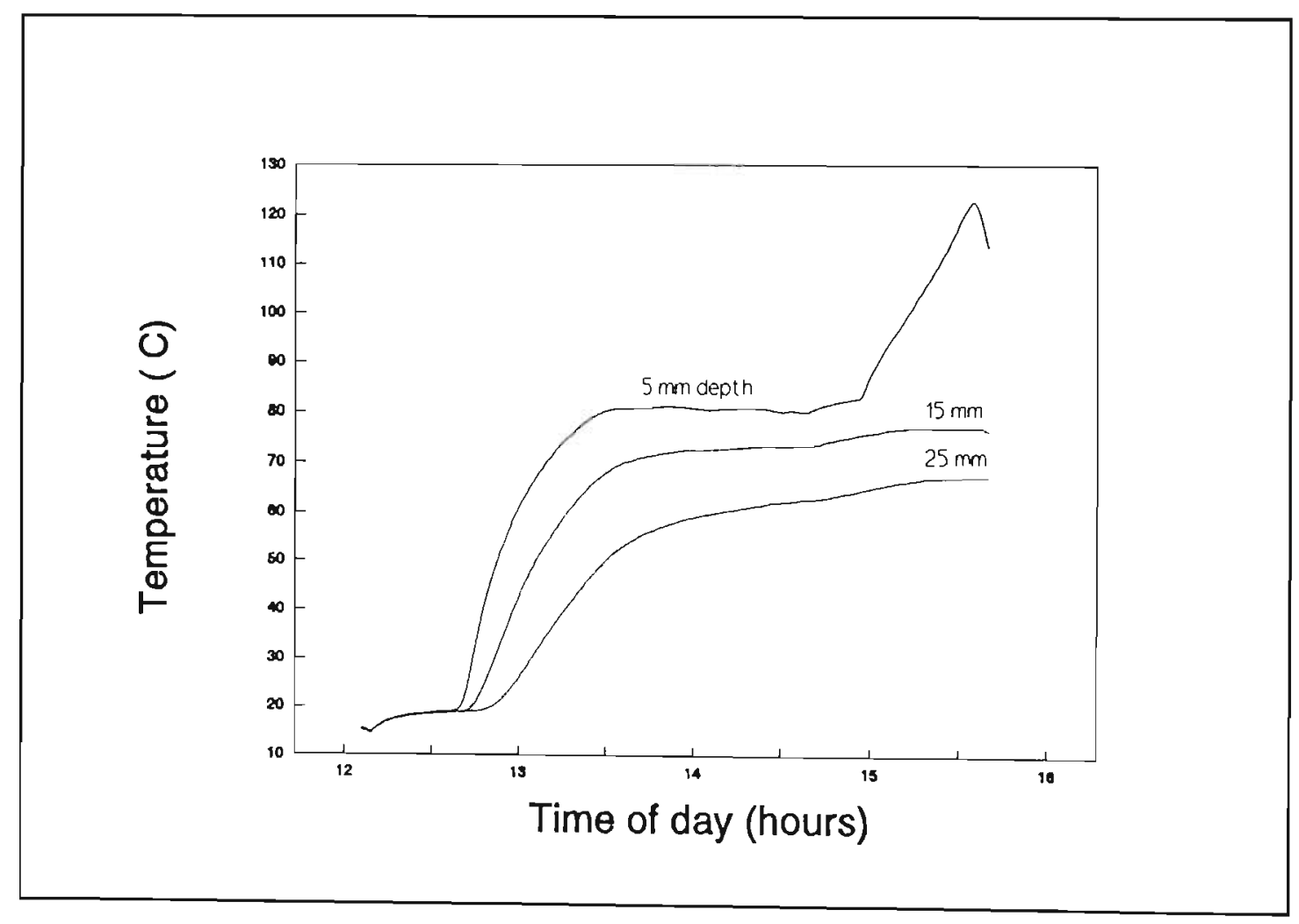

Figure 10.1 The temperature of the soil at different depths beneath a eucalypt slash pile during burning ( $E 1$, replicate 1 , near Richmond, Natal). 


\subsubsection{Problems Encountered with the Experiment}

Several problems were encountered in conducting this experiment. Mostly, these were the result of inexperience with the operation of the rainfall simulator. Consequently, the results are not of as much value as should have been possible. The most important problem was that the outside plots did not receive as much rainfall as the inner plots. Two causes are proposed:

(i) that the pump was run too slow so that the water pressure was not always as high as it should have been, and

(ii) that a spray nozzle on the outer end of one boom was faulty.

This was a serious problem because the burned plots were always on the outside, and as a result the treatment effects were confounded. Thus one cannot compare, with great confidence, the yields from the outer two plots (burned) with those from the inner two plots.

Other problems encountered included leakage of runoff water above the sill plate, causing an under-estimate of overland flow depth. Water supply at these remote sites was a logistical problem and contributed to the conservative pump speeds used.

\subsubsection{Analysis}

The variables of overland flow, soil loss and steady infiltrability were analysed, for significant differences resulting from location (blocks) and treatment, by a split plot analysis of variance (ANOVA) using the GLM procedure of the SAS statistical package (SAS Institute, 1985). This analysis was performed on data from the second run only as the first run serves to equilibrate conditions and account for differences in antecedent wetness between sites and plots. The appropriate error to test for differences between location is the mean square for replication within locations. The treatment by location interaction was not significant and was therefore dropped from the models, providing more degrees of freedom to test for treatment effects. 


\subsection{RESULTS AND DISCUSSION}

\subsubsection{Results of the Split Plot ANOVA}

The results of the ANOVA are given in Table 10.3 for the three variables of total overland flow depth, equilibrium infiltrability and soil loss. The means of these variables are summarised by location, treatment and run in Tables $10.4,10.5$ and 10.6 respectively, and are plotted in Figures 10.2, 10.3 and 10.4.

There were large differences between the different treatments at each location, and these over-shadowed differences between locations which were not significant (Table 10.3). Treatment effects were significant for the variables overland flow depth and soil loss (Table 10.3), but the same treatments did not have the same effect at different locations or sites.

Table 10.3 Results of the analysis of variance by a split plot design of three variables measured in the rainfall simulator trial.

\begin{tabular}{llrrrrl}
\hline $\begin{array}{l}\text { Dependent } \\
\text { variable }\end{array}$ & Source of variation & $\mathrm{df}$ & $\mathrm{SS}$ & $\begin{array}{c}\text { Mean } \\
\text { square }\end{array}$ & $\mathbf{F}$ & $\boldsymbol{a}>\mathbf{F}$ \\
\hline $\begin{array}{l}\text { Overland flow } \\
\text { depth }\end{array}$ & Locations & 2 & 522 & 261.4 & 0.35 & 0.73 \\
& $\begin{array}{l}\text { Replications within locations } \\
\text { Treatments }\end{array}$ & 3 & 2259 & 753.0 & & \\
& Error & 15 & 6273 & 2091.1 & 14.15 & 0.0001 \\
Steady & Locations & 2216 & 147.7 & & \\
infiltrability & Replications within locations & 3 & 1810 & 905.0 & 3.25 & 0.5 \\
& Treatments & 3 & 834 & 278.2 & & \\
& Error & 15 & 2483 & 165.8 & 1.85 & 0.18 \\
Soil loss & 2 & 4.824 & 2.412 & 0.88 & 0.5 \\
& Locations & 3 & 8.219 & 2.740 & & \\
& Replications within locations & 3 & 5.623 & 1.874 & 3.18 & 0.05 \\
& Treatments & 15 & 8.851 & 0.590 & & \\
\hline
\end{tabular}

Table 10.4 Overland flow and soil loss from the rainfall simulator plots averaged by the four treatments over three sites, two runs and two replicates, i.e. $n=12$. (The mean value is shown with its standard deviation in brackets).

\begin{tabular}{|c|c|c|c|c|c|}
\hline Treatment & $\begin{array}{l}\text { Overland flow } \\
\text { as per cent of } \\
\text { rain }\end{array}$ & $\begin{array}{c}\text { Steady } \\
\text { infiltration } \\
\left(\mathrm{mm} \mathrm{h}^{-1}\right)\end{array}$ & $\begin{array}{l}\text { Time to } \\
\text { equilibrate } \\
\text { (min.) }\end{array}$ & 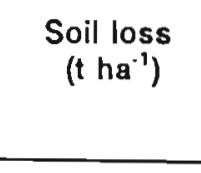 & $\begin{array}{c}\text { Soil loss per } \\
\text { mm of } \\
\text { simulated rain } \\
\left(\mathrm{kg} \mathrm{ha}^{-1} \mathrm{~mm}^{-1}\right)\end{array}$ \\
\hline Control & $\begin{array}{l}21.1^{*} \\
(14.0)\end{array}$ & $\begin{array}{l}35.5^{\star}+ \\
(14.9)\end{array}$ & $\begin{array}{l}8.2^{*} \\
(5.3)\end{array}$ & $0.34 *(0.43)$ & $\begin{array}{r}7.2 \text { * } \\
(10.6)\end{array}$ \\
\hline Bare fallow & $\begin{array}{c}48.7 \\
(24.4)\end{array}$ & $\begin{array}{l}21.2^{*} \\
(14.4)\end{array}$ & $\begin{array}{r}3.7 \\
(2.1)\end{array}$ & $2.24(2.31)$ & $\begin{array}{l}47.0+ \\
(49.6)\end{array}$ \\
\hline Burn, dry fuel & $\begin{array}{l}16.9^{*} \\
(14.6)\end{array}$ & $\begin{array}{c}36.2^{\star}+ \\
(16.6)\end{array}$ & $\begin{array}{l}17.4 \text { * } \\
(16.9)\end{array}$ & $0.61 *(0.67)$ & $\begin{array}{l}13.0^{*}+ \\
(15.2)\end{array}$ \\
\hline Burn, moist fuel & $\begin{array}{l}10.1^{*} \\
(7.6) \\
\end{array}$ & $\begin{array}{l}42.3+ \\
(14.0) \\
\end{array}$ & $\begin{array}{l}13.3^{*} \\
(12.0) \\
\end{array}$ & $0.90 *(1.79)$ & $\begin{array}{l}19.6{ }^{*}+ \\
(38.4)\end{array}$ \\
\hline
\end{tabular}

Means flanked by the same symbol $\left({ }^{*},+\right)$ are not significantly different at $a<0.05$ (Duncan's multiple range test). 
Table 10.5 Overland flow and soil loss from the rainfall simulator plots averaged by three locations over four treatments, two runs and two replicates, i.e. $n=16$.

\begin{tabular}{|c|c|c|c|c|c|}
\hline Location & $\begin{array}{l}\text { Overland } \\
\text { flow as per } \\
\text { cent of rain }\end{array}$ & $\begin{array}{c}\text { Steady } \\
\text { infiltration } \\
\left(\mathrm{mm} \mathrm{h}^{-1}\right)\end{array}$ & $\begin{array}{l}\text { Time to } \\
\text { equilibrate } \\
\text { (min.) }\end{array}$ & $\begin{array}{c}\text { Soil loss } \\
\text { (t ha') }\end{array}$ & $\begin{array}{l}\text { Soil loss per } \\
\text { mm of } \\
\text { simulated rain } \\
\text { (kg ha. } \mathrm{mm}^{\prime \prime} \text { ) }\end{array}$ \\
\hline Wattle (W) & $\begin{array}{c}22.5 \text { * } \\
(22.2)\end{array}$ & $\begin{array}{l}42.5^{\star} \\
(14.9)\end{array}$ & $\begin{array}{c}10.1^{\star} \\
(7.2)\end{array}$ & $\begin{array}{c}1.17{ }^{\star}+ \\
(1.17)\end{array}$ & $\begin{array}{c}23.8^{*}++ \\
(34.1)\end{array}$ \\
\hline $\begin{array}{l}\text { Eucalypt } 1 \\
\text { (E1) }\end{array}$ & $\begin{array}{l}33.3^{\star} \\
(27.3)\end{array}$ & $\begin{array}{l}24.2+ \\
(16.4)\end{array}$ & $\begin{array}{l}5.8 * \\
(3.1)\end{array}$ & $\begin{array}{l}1.98+ \\
(2.23)\end{array}$ & $\begin{array}{l}44.5{ }^{\star} \\
(46.1)\end{array}$ \\
\hline $\begin{array}{l}\text { Eucalypt } 2 \\
\text { (E2) }\end{array}$ & $\begin{array}{c}19.1^{\star} \\
(14.3)\end{array}$ & $\begin{array}{c}32.3^{\star}+ \\
(14.3)\end{array}$ & $\begin{array}{l}14.9^{*} \\
(17.0)\end{array}$ & $\begin{array}{l}0.16 \text { * } \\
(0.14)\end{array}$ & $\begin{array}{l}2.5+ \\
(2.0)\end{array}$ \\
\hline
\end{tabular}

Means flanked by the same symbol $\left({ }^{\star},+\right)$ are not significantly different at $a<0.05$ (Duncan's multiple range test).

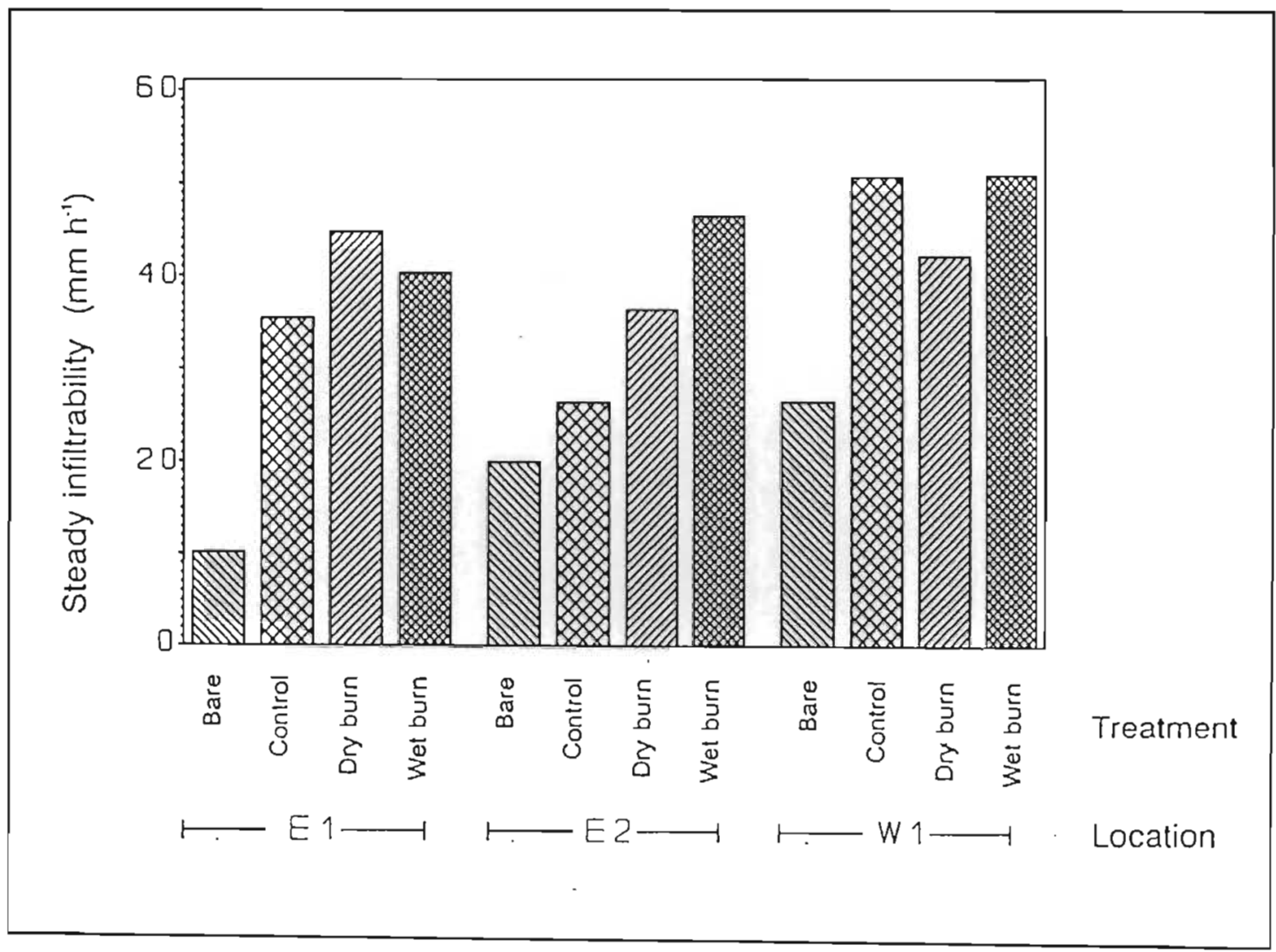

Figure $\mathbf{1 0 . 2}$ The mean steady infiltrability of two replicates of four treatments (bare, control, dry burn and wet burn) at three forestry locations in Natal. 


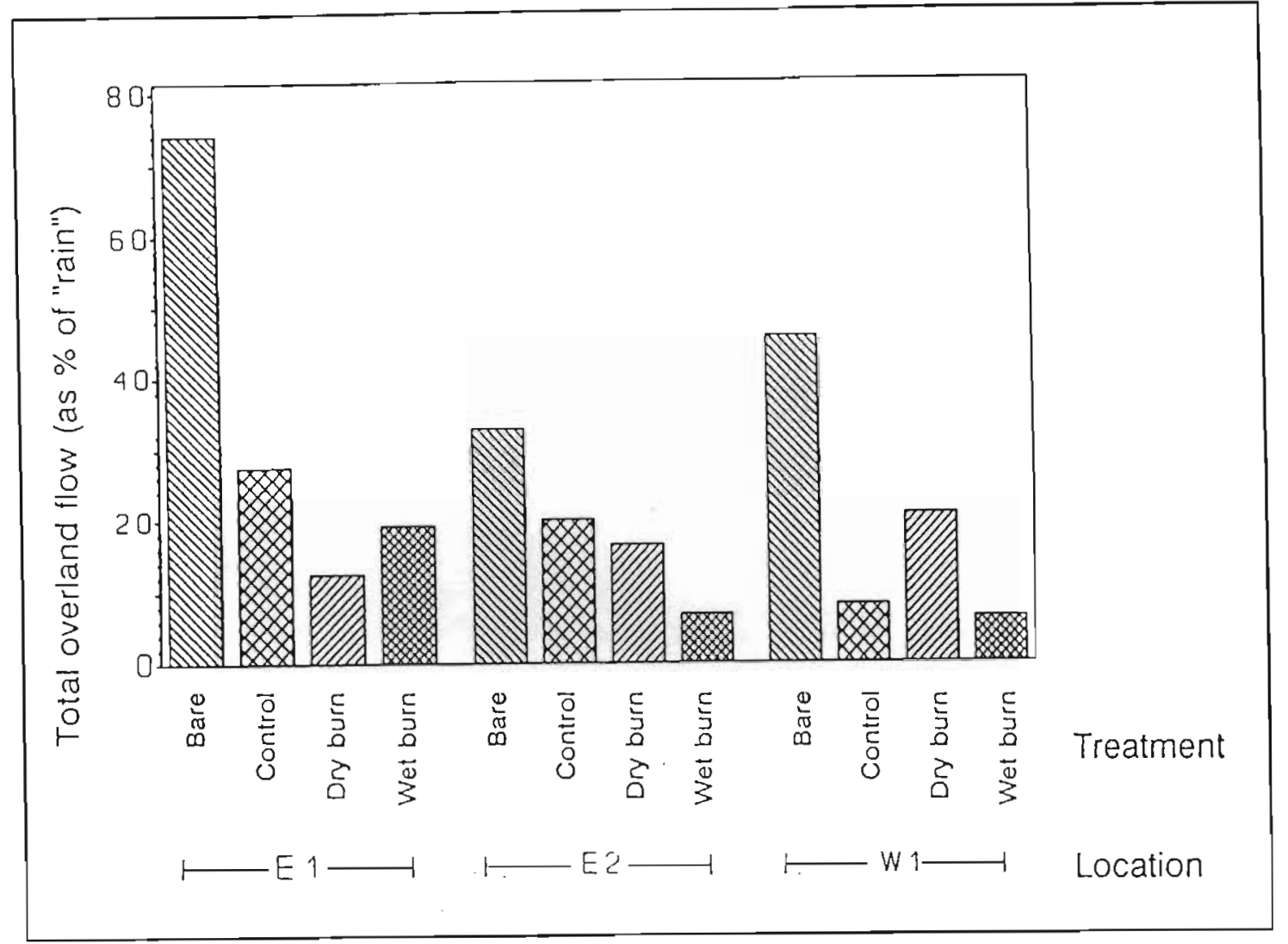

Figure 10.3 The mean overland flow depth (as a percentage of simulated rainfall) of two replicates of each of four treatments (bare, control, dry burn and wet burn) at three forestry locations in Natal.

Table 10.6 Overland flow and soil loss from the rainfall simulator plots averaged by run over four treatments, three locations and two replicates, i.e. $n=24$.

\begin{tabular}{|c|c|c|c|c|c|}
\hline Location & $\begin{array}{l}\text { Overland } \\
\text { flow as per } \\
\text { cent of rain }\end{array}$ & $\begin{array}{l}\text { Steady } \\
\text { infiltration } \\
\left(m \mathrm{~h} \mathrm{~h}^{-1}\right)\end{array}$ & $\begin{array}{l}\text { Time to } \\
\text { equilibrate } \\
\text { (min.) }\end{array}$ & $\begin{array}{l}\text { Soil loss } \\
\left.\text { (t ha' } \mathbf{a}^{-1}\right)\end{array}$ & $\begin{array}{l}\text { Soil loss per mm } \\
\text { of simulated rain } \\
\left(\mathrm{kg} \mathrm{ha}^{-1} \mathrm{~mm}^{-1}\right)\end{array}$ \\
\hline First run & $\begin{array}{r}19.7 \\
(20.7)\end{array}$ & $\begin{array}{c}40.5 \\
(14.5)\end{array}$ & $\begin{array}{c}15.4 \\
(15.6)\end{array}$ & $\begin{array}{c}1.35 \\
(2.10)\end{array}$ & $\begin{array}{c}25.3 \\
(41.4)\end{array}$ \\
\hline $\begin{array}{l}\text { Second } \\
\text { run }\end{array}$ & $\begin{array}{c}27.9 \\
(22.1)\end{array}$ & $\begin{array}{c}28.2 \\
(16.2)\end{array}$ & $\begin{array}{c}6.7 \\
\text { (3.9) }\end{array}$ & $\begin{array}{c}0.76 \\
(1.09)\end{array}$ & $\begin{array}{c}18.7 \\
(29.5)\end{array}$ \\
\hline
\end{tabular}

The one consistent effect was that the bare plot produced the highest overland flow, reflected in the lowest infiltrability, and consequently the highest soil losses (Table 10.4; Figures 10.2 10.4). At the wattle sites the dry fuel burn plots produced slightly more runoff than the other two treatments, but at the other two sites the two burned plots produced the lowest overland flow and had the highest steady infiltrability (Figures $10.2-10.4$ ). The clear soil loss results were 


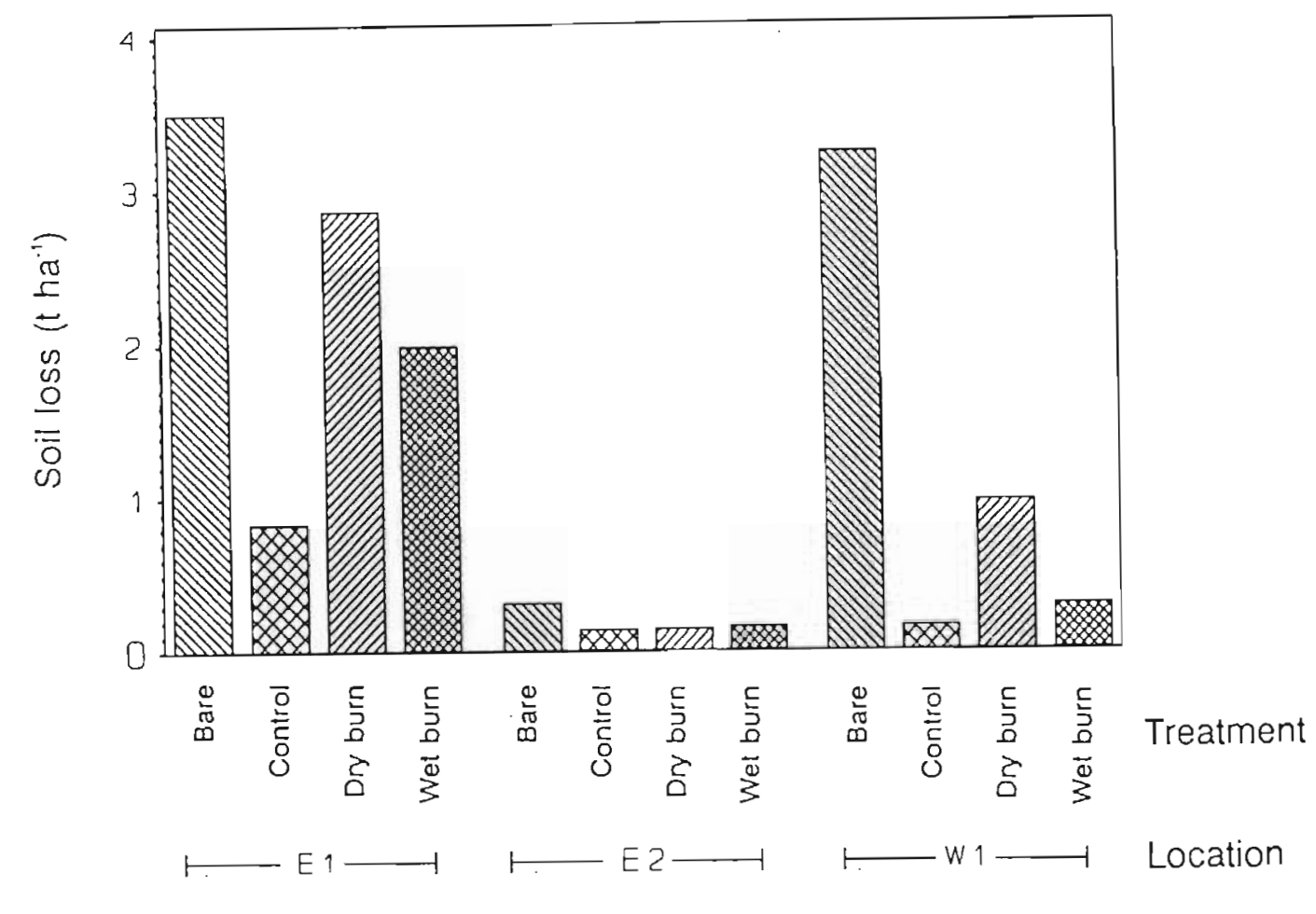

Figure 10.4 The mean soil loss of two replicates of each of four treatments (bare, control, dry burn and wet burn) at three forestry locations in Natal.

(i) that the bare plot had the highest soil loss, and

(ii) that the control plot, with a generally undisturbed cover of plantation litter, produced the least.

To some extent the relatively limited effect of the fire is attributed to the unequal spray of the rainfall simulator. This makes comparisons between the inner plots and the outer plots somewhat uncertain. But comparisons between the bare and control plots are important.

\subsubsection{Location}

The second eucalypt location (E2; Mid-Illovo) was markedly different from the other two locations (Richmond). The soil had a higher bulk density and gravel content, and was generally much more strongly aggregated, with a shallow A-horizon. No repellency effects were noticeable before or after the fire. Infiltration appeared to be limited by the physical properties of the soil. Soil loss was limited by strong aggregation which reduced erodibility. After the second run, soil profiles were cut open and were well wet through their full depth $(-400 \mathrm{~mm})$, with signs of well-developed macro-pore flow below $300 \mathrm{~mm}$. 
The soils of the first two locations were similar, with deep $(300-400 \mathrm{~mm})$ friable A-horizons with a high organic matter content (Table 10.1). The soils appeared to present ideal conditions for a high infiltrability, although they were also fairly erodible. However, at both locations the soil showed strong water repellency before the fire.

\subsubsection{Effects of Treatments}

The only obvious fire effect was that ash and some patches of soil were wettable after the fire. After the rainfall simulator runs the soil profiles were unevenly wet, with the burned plots showing the tin-roof effect (cf. Section 2.1.3.3) quite clearly in places. There were also zones in which infiltration had obviously concentrated. The soil was more erodible after the fire, hence the higher soil losses relative to those of the control plots.

At the second eucalypt site (E2) the fires did not appear to affect the soil wettability and had the beneficial effect of leaving ash and charred timber on the site as surface storage for water. The soil erodibility appeared to have been increased on at least one of the plots, relative to the control, but to a minor extent.

The consistently higher overland flow and soil loss from the bare plots was due to the lack of surface storage capacity. Overland flow was initiated early in the run and reached a steady level sooner than in the other plots (Table 10.4). Infiltration was impeded very greatly by water repellency in the soils at the two Richmond locations, and the high soil losses were due to the friable nature of the exposed soils and the high surface run-off. The shallow but largely undisturbed litter on the control plots made a more important difference than would have been expected from its appearance. By retaining and detaining water on the surface of the water repellent soils, the infiltrability of the same unburned soil was roughly doubled. By the same mechanism the wettable soil layer and fire debris on the burned plots made it possible for water to be detained for long enough to aid infiltration.

\subsubsection{First vs Second Run}

As was expected the second run of the two at each site produced overland flow sooner, and reached an equilibrium level sooner as the plot was already wet (Table 10.6). The steady infiltrability levels reached in the second run were slightly lower than those of the first run but soil loss, despite the greater volume of overland flow, appeared to be lower 
on the second run (Table 10.6). Part of the explanation for this is the shorter storms in the second run (Table 10.2), but given the high levels of overland flow recorded in the second run, the results do indicate a degree of sediment exhaustion on the plots.

\subsubsection{Role of Repellency}

The wettability of the soils did not appear to play any role at the second eucalypt location, E2. At both the Richmond locations, $E 1$ and $W$, the plantation litter had created a high level of repellency in the soils independent of the role of fire. All mineral soil was repellent to depths of around $100 \mathrm{~mm}$. Relative to the properties of a larger sample of soils (Chapter 9 ), both these soils rated as highly repellent, and the repellency was relatively persistent. The eucalypt soil had more strongly developed repellency that the wattle soil. At both Richmond locations the treatment burns removed repellency from surface soil over part of the plots, but it was not clear that repellency at deeper levels in the soil was any more severe after the fire on these treatment plots.

\subsection{CONCLUSIONS}

The experiment failed to confirm the primary hypothesis which it was expected to support, that is, to replicate the fire effects seen in catchments by inducing water repellency in soils of the burned plots. The main reasons for the failure of the experiment to support the hypothesis were

(i) poor site selection, in that the soils on which the experiment was performed were either repellent already ( $E 1$ and $W$ ) or showed little potential to develop fire-induced repellency (E2); and

(ii) the inability to keep the soils of the plots to be burned from attaining high soil wetness prior to burning, which kept soil temperatures at a moderate level during the application of the treatments.

The rainfall simulator trials showed the importance of a litter cover or natural mulch in limiting soil loss, and maintaining a high infiltrability relative to disturbed sites. The advantage the naturally mulched plot had over the bare plot, in terms of infiltrability, was not equalised even after the second high intensity storm within 24 hours. Soil loss was generally closely related to the overland flow depth and rate, yet at all three locations the 
soil loss per unit of overland flow was lower off the control plots than off the burned plots (Table 10.4 and Figures 10.3 and 10.4).

These results, taken together with those of the Ntabamhlope fire (Chapter 7), indicate that one of the more important effects of fire is to remove ground cover (especially litter, which is in contact with the ground) thereby exposing the soil to overland flow, by removing detention and retention storage. Exposing bare soil could have other negative effects (such as crust formation) in the long term, but this experiment showed that the storage capability of litter was very important. Plots with storage, through litter or wettable soil, or both, had higher infiltrability and lower soil loss than the bared plots.

The uneven generation of overland flow, even within the small $(10 \times 1.8 \mathrm{~m})$ plots illustrates the complexity of flow generation processes. The high variability between treatments and locations illustrates the need for many replicates of such experiments before general conclusions can be drawn from the results. 


\section{CHAPTER 11}

\section{CONCLUSIONS}

\subsection{REPELLENCY AS AN AGENT FOR HYDROLOGICAL EFFECTS OF FIRE}

I set out to examine the hypothesis that fire would induce water repellency in the soil (thereby increasing the probability of overland flow, the magnitude of storm-flows and water yield) and would increase sediment yields. The hypothesis was well supported in the two afforested catchments but only partially supported in the burned fynbos catchments. In the afforested catchments, water repellent soils and the resultant overland flow are seen as the main causes of fire effects because of the large amounts of soil eroded off midslope plots and the changed shape of the hydrographs which were of much the same duration before and after the fires. In the eucalypt afforested Ntabamhlope catchment, it was not clear that the general and severe water repellency in the soils was any worse as a result of the fire. In the case of the fynbos catchments the occurrence of fire-induced water repellent soils was patchy, but contributed to significant increases in overland flow and soil loss from mid-slope sites (relative to the unburned condition) for a short period after the fires. On the catchment scale though, little of the surface runoff appears to have reached the streams, with the result that the fire had little effect on the catchments' hydrological behaviour, and it is concluded that the overall mode of stream-flow generation remained unchanged. Thus it is clear that repellency does not operate alone but is one element of a complex association of factors, which together determine the response of a catchment to fire.

Water repellent soils played a role, at two of the three locations, in the generation of overland flow from small plots exposed to simulated rain. Under both wattle and eucalypt plantation types the inherent repellency of the dry soils was extreme, such that fire-induced water repellency was not a factor in the response of the plots. The important role of fire was in burning-off of repellency in the surface layer of the soil. This wettable soil (and, more importantly, any litter) provided water storage capacity which reduced overland flow and soil loss during the simulated rain-storms relative to plots with a bare surface. 
Water repellent soils, unrelated to fire, are a common feature of timber plantations in South Africa, on a wide range of soil types and textures. The vegetation type and the length of time which litter remains on the soil surface, and hence the interval between fires, are apparently important factors in the development of repellency. On the basis of these studies, the majority of timber plantations are vulnerable to erosion by overland flow following high-intensity fires which induce greater levels of water repellency in the soils and/or expose inherently repellent soils by removing ground cover.

\subsection{THE COMPLEXITY OF FIRE EFFECTS}

While the hypothesis of water repellency as an agent for altered hydrological behaviour is supported to some extent, this study highlights the fact that the hydrological response of catchments to fire is governed by numerous factors interacting with each other. It is thus difficult to predict the consequences of any particular fire, but the role of some of these factors is now clearer. Forest and catchment managers should therefore be in a better position to understand the effects of fire and to adapt the management to prevent or ameliorate the hydrological effects of fire.

The following conditions pre-dispose a catchment to a marked hydrological response to fire.

(i) Vegetation types which lead to the development of water repellent soils improve the chances of a sharp hydrological response to fire. In the two afforested research catchments the soils beneath the pines and eucalypts showed a high level of repellency, which played a part in generating overland flow in the post-fire situation. It has been shown that high levels of water repellency are a common feature of the soil of timber plantations in South Africa. Soils beneath eucalypts are particularly likely to develop water repellency. Soil beneath pines had high levels of repellency only after fire. In the fynbos, fire caused a minor increase in water repellency, which probably contributed to the observed overland flow and soil loss off plots on mid-slope sites.

(ii) A high level of soil heating, which itself is a function of fuel load, fuel and soil wetness, site and weather conditions will greatly increase the risk of a sharp response to fire. High soil temperatures were positively related to levels of induced water repellency (in the case of the pine and fynbos catchments) and to post-fire 
soil erodibility. Soil and fuel wetness can greatly affect the soil heating which takes place during fire. Hence prescribed burns which are only likely to be applied after rains are unlikely to combust fully all fuels or litter, and therefore are less likely to cause widespread serious soil heating .

(iii) The loss of ground cover due to shading out of low-growing forbs and shrubs, as occurs following canopy closure in a timber plantation, cause the site to be bare for longer after fire, by reducing the rate of plant re-growth, and thereby enhancing the risk of a hydrological response to fire.

(iv) The removal (by combustion) of plant litter from the soil surface in higher intensity fires is clearly important in reducing surface storage capacity (retention and detention) on the site, and in removing obstacles to flow of water and the transport of eroded soil particles.

(v) The roads, tracks or skid-paths, as can be expected within a managed forest or plantation, become potential extensions of the channel system after a fire, improving the probability of overland flow reaching the stream and contributing to storm-flow. Associated with overland flow is a greater likelihood of soil erosion and sediment pulses.

(vi) Wildfires may occur under any conditions, but in the hot, dry and windy conditions in which they would normally be encountered, are more likely to be high intensity burns causing a maximum of soil heating, and holding the greatest potential for hydrological effects. The Langrivier wildfire was an exception as it burned in fairly moist conditions: it was an accidental fire which occurred under conditions considered safe for the burning of fire-breaks. Prescribed burns are applied under conditions likely to produce a controllable burn with known characteristics. Fuel and weather conditions required for a controllable fire make it unlikely that soil heating effects will be as damaging during a prescribed burn as may be expected during a wildfire. The generalised distinction which is commonly made between wildfires and prescribed burns seems to be justified in terms of the risk of hydrological effects. 


\subsection{THE SIGNIFICANCE OF RIPARIAN ZONES AS BUFFER STRIPS}

None of the studies conducted as part of this thesis set out to test or demonstrate the efficiency of riparian zones as buffer strips about streams. However, the importance of riparian zones seems to have been confirmed in this study. Indigenous riparian forests in both Swartboskloof and Langrivier are not prone to fire and largely escaped the fires which burned the rest of these catchments. At Ntabamhlope the grassed riparian zone was quick to re-sprout after fire and not only was resistant to erosion itself but trapped much soil which was eroded off the higher plantation slopes. In Bosboukloof, much of the riparian forest within the plantation was burned and here its role as a sediment trap and buffer strip appeared to be diminished. Within plantations a riparian zone which is large enough to be managed and maintained in short, re-sprouting vegetation with a high basal cover would seem to be an ideal buffer against pollution, particularly by sediment, of streams.

\subsection{PLOTS AS MEANS OF STUDYING STREAM-FLOW GENERATION}

While it is important to know what is happening within the catchment as a means of understanding processes, plots are not a substitute for catchment studies, and what happens at the scale of a plot cannot be extrapolated to the scale of the catchment. The response of plots is highly variable, even under the relative uniformity of simulated rainfall. On a single rain-fed plot reasonably good relationships were established between the dependent variables (overland flow and soil loss) and the driving variables, but the response of different plots to the same rain events were difficult to predict. The area within a plot which contributes to the overland flow which actually arrives in the collecting apparatus could be the most important variable in explaining the response of a plot to rainfall. The size of this contributing area is, in turn, probably a reflection of the inherent spatial variability of soil properties controlling infiltrability and percolation rates. By averaging the plot's response by the area of the whole plot (to derive a depth of runoff or soil loss per unit area) it is likely that the highest yields will appear to be produced by the smallest plots. 


\subsection{LESSONS FOR FOREST MANAGEMENT}

\subsubsection{Preventative Measures}

The two fires in timber plantations demonstrated some of the economic consequences of fire. In both, soil losses represent a substantial loss of fertile topsoil and nutrient-rich ash which could well reduce future productivity. The cost of repairs to roads, culverts and drains was considerable. Sedimentation and flooding following the Bosboukloof fire had direct costs and posed a risk to motorists on a public road below the catchment. But for the fact that the Ntabamhlope catchment is very remote, the fire here is likely to have had similar economic consequences.

Obviously wildfires cannot all be prevented, but it is recommended that fuel management programmes be implemented to prevent extreme soil heating during wildfire. Measures can be taken to reduce the risk of severe damage by wildfire by managing fuels. Slash should not be bundled or alternatively bundles should be kept on the contour or in discontinuous heaps. Fuels could be burned under optimal burning conditions, at a frequency which limits the build-up of loads to potentially dangerous levels. Discharge from road drains and skid paths should not lead directly to streams, as this will reduce the chance of infiltration of surface water and the deposition within the catchment of eroded soils.

Once a high intensity fire has passed through a plantation, managers should be aware of the resultant risk of accelerated soil erosion and high storm-flows. Drains should be opened and maintained in good working order to prevent damage to roads and structures. Leaving slash and waste timber along the contour will impede the flow of water and trap sediments on site. Where site preparation is practised, ploughing or ripping on the contour will break through the repellent surface soil and provide a zone where water entry is not impeded. Such site preparation will also increase the surface storage capacity for rain water, reducing the risk of problems with overland flow and soil erosion.

\subsubsection{Using Fire}

Given the results of the two fynbos fires at Swartboskloof and Langrivier, the implication for catchment management is that fires can be applied outside of the extremes of the dry 
season without having a marked hydrological effect. Key provisions for successful burning were high soil and fuel wetness, and protection of the riparian zone. Critical levels of soil and fuel wetness would depend on the energy available for soil heating, as well as insulation of soil by litter. Judging from the Swartboskloof study, a mean soil wetness of $15 \%$ in the top $50 \mathrm{~mm}$ and fuel wetness of around $30 \%$ was adequate to restrict fire effects to acceptable limits. Under such conditions of sufficient wetness, soil heating, and, as a result, the combustion of surface litter and organic matter within the soil matrix, will be much reduced. These are the factors most likely to determine fire's effect on the infiltrability and percolation rates and erodibility of the soil after fire. The older the vegetation of a catchment is allowed to become the greater will be the risk of a wildfire which may cause undesirable hydrological effects. Fuel loads build up over time and water repellent soils can be expected to develop through prolonged contact between plant litter and the soil.

\subsection{SIMULATION MODELLING OF THE HYDROLOGICAL EFFECTS OF FIRE}

This simulation exercise has demonstrated the potential for using $A C R U$ as a planning tool. The magnitude of floods, or the increased size of floods following wildfire in a catchment, can be predicted with moderate success. The ability to model the effects of fire is is an important requirement as the results of this thesis show that it is clearly not safe to assume that flow predictions developed for a vegetated catchment will still apply to a catchment after a wildfire. Predictive models are of course especially useful for areas where good data are scarce, and will find particular application where forested catchments are situated above urban developments.

\subsection{THIS THESIS AS AN ORIGINAL CONTRIBUTION TO SCIENCE}

A prime requirement for the Ph.D. degree is that the work must be an original contribution to the science. The following points are made in justification of the originality of this thesis.

(i) This study provides the first scientific testing of an hypothesis to explain the variation in the hydrological effects of fire in South Africa, and introduces the phenomenon of water repellency as a causative link in fire effects in this country. 
(ii) This is the first study of water repellency, hillslope runoff and erosion and catchment response to fire within a single catchment after one fire.

(iii) Studies in this thesis represent the first complete quantification of water repellency and its associated hydrological effects in a single catchment.

(iv) Chapter 9 incorporates the first quantitative and broad geographic assessment of the water repellency of South African soils, and the role of vegetation types and other factors in its development.

(v) The thesis provides guidelines for revised management practices developed from a scientific study of the effects of fire and its causes.

(vi) In view of the above points, I consider that this thesis is a significant contribution to the understanding of stream-flow generation and soil loss in timber plantations and mountain catchments, within the given physical conditions represented. 


\section{REFERENCES}

Acocks, J.P.H., 1975. Veld types of South Africa. Second Edition, edited by D.J.B. Killick, Memoirs of the Botanical Survey of South Africa No. 40.

Adams F., Ewing, P.A. and Huberty, M.R., 1947. Hydrologic aspects of burning brush and woodland-grass ranges in California. California Division of Forestry.

Adams, S., Strain, B.R. and Adams, M.S., 1969. Water-repellent soils, fire, and annual plant cover in a desert scrub community of southeastern California. Ecology, 51: 698-700.

Albini, F.A., 1976. Applications of wildland fire behaviour models. Paper presented 1976 Fall Meeting of Western States Section, The Combustion Institute, October 1976, La Jolla, California.

Alexander, M.E., 1982. Calculating and interpreting forest fire intensities. Canadian Journal of Botany, 60: 349-357.

Allison, G.B. and Hughes, M.W., 1983. The use of natural tracers as indicators of soilwater movement in a temperate semi-arid region. Journal of Hydrology, 60: 157-173.

Anderson, H.W., 1949. Does burning increase surface runoff? Journal of Forestry, 47: 5457.

Anderson, H.W., 1976. Fire effects on water supply, floods, and sedimentation. Proceedings Annual Tall Timbers Fire Ecology Conference, 15: 249-260.

Anderson, H.W., Coleman, G.B., Zinke, P.J., 1959. Summer slides and winter scour dry-wet erosion in southern California mountains. USDA Forest Service, Pacific Southwest Forest and Range Experiment Station, Technical Paper 36.

Anderson, H.W., Hoover, M.D. and Reinhart, K.G., 1976. Forests and water: Effects of forest management on floods, sedimentation and water supply. USDA Forest Service, General Technical Report PSW-18, Pacific Southwest Forest and Range Experiment Station, Berkeley, California, USA.

Arend, J.L., 1941. Infiltration rates of forest soils in the Missouri Ozarks as affected by wood burning and litter removal. Journal of Forestry, 39: 726-728.

Atkinson, G., 1984. Erosion damage following bushfires. Journal of the Soil Conservation Service of New South Wales, 40: 4-9.

Banks, C.H., 1964. Further notes on the effect of autumnal veld burning on storm flow in the Abdolskloof catchment, Jonkershoek. Forestry in South Africa, 4: 79-84.

Bentley, J.P. and Fenner, R.L., 1958. Soil temperatures during burning related to post-fire seedbeds on woodland range. Journal of Forestry, 56: 737-740. 
Beven, K., 1987. Towards a new paradigm in hydrology. In: Water for the Future: Hydrology in perspective. Proceedings Symposium, Rome 1987. IAHS Publication no. 164: 393-403.

Bishay, B.G. and Bakhati, H.K., 1976. Water repellency of soils under citrus trees in Egypt and means of improvement. Agricultural Research Review, 54: 63-74.

Biswell, H.H. and Schultz, A.M., 1957. Surface runoff and erosion as related to prescribed burning. Journal of Forestry, 55: 372-374.

Blong, R.J., Riley, S.J. and Crozier, P.J., 1982. Sediment yield from runoff plots following bushfire near Narrabeen Lagoon, NSW. Search, 13: 36-38.

Boden, D.I. 1992. Site index studies. In: MacLennan, L. (Editor). Annual Research Report of the Institute for Commercial Forestry Research. p. 21-30. ICFR, Pietermaritzburg.

Bond, R.D., 1964. The influence of the microflora on the physical properties of soils II. Field studies on water repellent sands. Australian Journal of Soil Research, 2: 123-131.

Bond, R.D. and Harris, R.R., 1964. The influence of the microflora on physical properties of soils I. Effects associated with filamentous algae and fungi. Australian Journal of Soil Research, 2: 111-122.

Bosch, J.M., 1980. 'n Ontleding van die hidrologiese eksperimente in die Cathedral Peak opvangebiede. Unpublished M.Sc. thesis, Faculty of Forestry, University of Stellenbosch.

Bosch, J.M. and Hewlett, J.D., 1982. A review of catchment experiments to determine the effect of vegetation changes on water yield and evapotranspiration. Journal of Hydrology, 55: 3-23.

Bosch, J.M., Schulze, R.E. and Kruger, F.J., 1984. The effect of fire on water yield. In: Booysen, J. de V. and Tainton, N.M. (Editors). The ecological effects of fire in South African ecosystems. Springer-Verlag, Berlin.

Bosch, J.M., Van Wilgen, B.W. and Bands, D.P., 1986. A model for comparing water yield from fynbos catchments burnt at different intervals. Water SA, 12: 191-196.

Brown, A.A., and Davis, K.P., 1973. Forest fire - control and use. McGraw-Hill, New York.

Brown, J.A.H., 1972. Hydrologic effects of a bushfire in a catchment in south-eastern New South Wales. Journal of Hydrology, 15: 77-96.

Burch, G.J., Moore, I.D. and Burns, J., 1989. Soil hydrophobic effects on infiltration and catchment runoff. Hydrological Processes, 3: 211-222.

Campbell, R.E., Baker, M.B.J., Ffolliott, P.F., Larson, L.R. and Avery, C.C., 1977. Wildfire effects on a ponderosa pine ecosystem: an Arizona case study. USDA Forest Service, Research Paper RM-191. Rocky Mountain Forest and Range Experiment Station, Fort Collins, Colorado, USA.

Chandler, C., Cheney, P., Thomas, P., Trabaud, L. and Williams, D., 1983. Fire in forestry, Vol. 1 - Forest fire behaviour and effects. John Wiley and Sons, New York. 
Colman, E.A., 1951. Fire and water in southern California's mountains. USDA Forest Service, California Forest and Range Experiment Station, Miscellaneous Paper No. 3.

Cooper, C.F., 1961. Controlled burning and watershed condition in the White Mountains of Arizona. Journal of Forestry, 59: 438-442.

DeBano, L.F., 1966. Formation of non-wettable soils ... involves heat transfer mechanism. USDA Forestry Service, Research Note PSW-132, Pacific Southwestern Forest and Range Experiment Station, Berkeley, California.

DeBano, L.F., 1969a. Water movement in water-repellent soils. In: DeBano, L.F. and Letey, J. (Editors). Proceedings Symposium, Water-repellent soils (May 1968, Riverside, California). University of California, Riverside. pp. 61-69.

DeBano, L.F., 1969b. The relationship between heat treatment and water repellency in soils. In: In: DeBano, L.F. and Letey, J. (Editors). Proceedings Symposium, Water-repellent soils (May 1968, Riverside, California). University of California, Riverside. pp. 265-279.

DeBano, L.F., 1969c. Water repellent soils: a worldwide concern in management of soil and vegetation. Agricultural Science Review, 7: 11-18.

DeBano, L.F., 1971. The effect of hydrophobic substances on water movement in soil during infiltration. Soil Science Society of America Proceedings, 35: 340-343.

DeBano, L.F., 1981. Water repellent soils: a state-of-the-art. USDA Forest Service, General Technical Report PSW-46. Pacific Southwest Forest and Range Experiment Station, Berkeley, California, USA.

DeBano, L.F. and Conrad, C.E., 1976. Nutrients lost in debris and runoff water from a burned chaparral watershed. In: Proceedings of Third Inter-Agency Sedimentation Conference, Denver, Colorado, pp. 3-13 to 3-27.

DeBano, L.F. and Krammes, J.S., 1966. Water repellent soils and their relation to wildfire temperatures. International Association of Scientific Hydrologists Bulletin, XI Annee 2: 1419.

DeBano, L.F., Dunn, P.H. and Conrad, C,E., 1977. Fire's effect on physical and chemical properties of chaparral soils. In: Proceedings of the Symposium on Environmental Consequences of Fire and Fuel Management in Mediterranean Ecosystems, August 1977, Palo Alto, California. USDA Forest Service, Gen. Tech. Rep. WO-3, pp. 65-74. Pacific Southwest Forest and Range Experiment Station, Berkeley, California, USA.

DeBano, L.F., Mann, L.D. and Hamilton, D.A., 1970. Translocation of hydrophobic substances into soil by burning organic litter. Soil Science Society of America, Proceedings, 34: 130-133.

DeBano, L.F., Osborn, J.F., Krammes, J.S. and Letey, J., 1967. Soil wettability and wetting agents ... our current knowledge of the problem. USDA Forest Service, Research Paper PSW-43. Pacific Southwest Forest and Range Experiment Station, Berkeley, California, USA. 
DeBano, L.F., Rice, R.M., and Conrad, C.E., 1979. Soil heating in chaparral fires: effects on soil properties, plant nutrients, erosion, and runoff. USDA Forest Service Research Paper PSW-145.

DeBano, L.F., Savage, S.M., and Hamilton, D.A., 1976. The transfer of heat and hydrophobic substances during burning. Soil Science Society American Journal, 40: 779-782.

DeByle, N.V., 1973. Broadcast burning of logging residues and the water repellency of soils. Northwest Science, 47: 77-87.

DeByle, N.V. and Packer, P.E., 1972. Plant nutrient and soil losses in overland flow from burned forest clearcuts. In: Proceedings Symposium, Watersheds in Transition, (Logan, Utah, 1972). American Water Resources Association, pp. 296-307.

Dunne, T. and Leopold, L.B., 1978. Water in environmental planning. WH Freeman, San Francisco.

Dyrness, C.T., 1976. Effect of wildfire on soil wettability in the High Cascades of Oregon. USDA Forest Service, Research Paper PNW-202, Pacific Northwest Forest and Range Experiment Station, Portland, Oregon, USA.

Ellies, A., 1983. Effects of heat treatment on wettability of some soils of southern Chile (in German with abstract in English). Geoderma, 29: 129-138.

Everett, M.J., 1990. The modification and verification of a one-dimensional soil waterflow model. Unpublished M.Sc. thesis. Department of Agricultural Engineering, University of Natal, Pietermaritzburg.

Everson, C.S., George, W.J., and Schulze, R.E.., 1989. Fire regime effects on canopy cover and sediment yield in the montane grasslands of Natal. South African Journal of Science, 85: 113-116.

Finlayson, B.L. and Wong, N.R., 1982. Storm runoff and water quality in an undisturbed forested catchment in Victoria. Australian Forest Research, 12: 303-315.

GENSTAT, 1987. GENSTAT 5 Committee of the Statistics Department, Rothamsted Experiment Station, Genstat 5 Reference manual. Oxford University Press, Oxford.

Gilmour, D.A., 1968. Water repellence of soils related to surface dryness. Australian Forestry, 32: 143-148.

Gilmour, D.A. and Cheney, N.P., 1968. Experimental prescribed burn in Radiata pine. Australian Forestry, 32: 171-178.

Giovannini, G. and Lucchesi, S., 1983. Effect of fire on hydrophobic and cementing substances of soil aggregates. Soil Science, 136: 231-236.

Good R.B., 1973. A preliminary assessment of erosion following wildfires in Kosciusko National Park, NSW in 1973. Journal Soil Conservation Service New South Wales, 29: 191-199. 
Grelewicz, A. and Plichta, W., 1983. Water absorption of xeromor forest floor samples. Forest Ecology and Management, 6: 1-12.

Hammond, L.C. and Yuan, T.L., 1969. Methods of measuring water repellency of soils. In: DeBano, L.F. and Letey, J. (Editors). Proceedings Symposium, Water-repellent soils (May 1968, Riverside, California). University of California, Riverside. pp. 49-60.

Heede, B.H., Harvey, M.D. and Laird, J.R., 1988. Sediment delivery linkages in a chaparral watershed following a wildfire. Environmental Management, 12: 349-358.

Helvey, J.D., Tiedemann, A.R. and Fowler, W.B., 1976. Some climatic and hydrological effects of wildfire in Washington State. Proceedings Annual Tall Timbers Fire Ecology Conference, 15: 201-222.

Hewlett J.D., 1982. Principles of Forest Hydrology. University of Georgia Press, Athens.

Hewlett, J.D. and Bosch, J.M., 1984. The dependence of storm flows on rainfall intensity and vegetal cover in South Africa. Journal of Hydrology, 75: 365-381.

Hewlett, J.D. and Hibbert, A.R., 1967. Factors affecting the response of small watersheds to precipitation in humid areas. In: Sopper, W.E. and Lull, H.W. (Editors) Forest Hydrology, Proceedings Symposium. Pergamon Press, Oxford.

Heyward, F., 1938. Soil temperature during forest fires in the Longleaf pine region. Journal of Forestry, 36: 478-491.

Higgins, K.B., Lamb, A.J. and van Wilgen, B.W., 1987. Root systems of selected plant species in mesic fynbos in the Jonkershoek Valley, South Western Cape Province. South African Journal of Botany, 53: 249-257.

Hillel, D., 1980. Introduction to Soil Physics. Academic Press, New York.

Holzhey, C.S., 1969. Water repellent soils in southern California. In: DeBano, L.F. and Letey, J. (Editors), Proceedings Symposium, Water-repellent Soils (May 1968, Riverside, California). University of California, Riverside. pp. 31-41.

Horton, R.E., 1933. The role of infiltration in the hydrologic cycle. Transactions of the American Geophysical Union, 14: 446-460.

Hosking, J.S., 1938. The ignition at low temperatures of the organic matter in soils. Journal of Agricultural Science, 38: 393-400.

Hoyt, W.G. and Troxell, H.C., 1934. Forests and stream flow. American Society Civil Engineers Transactions, 99: 1-30.

Hudson, J., Kellman, M., Sanmugadas, K. and Alvarado, C., 1983. Prescribed burning of pinus oocarpa in Honduras - 1. Effects on surface runoff and sediment loss. Forest Ecology and Management, 5: 269-281.

Humphreys, F.R. and Lambert, M.J., 1965. Soil temperature profiles under slash and log fires of various intensities. Australian Forestry Research, 1: 23-24. 
Jamison, V.C., 1947. Resistance of wetting in the surface of sandy soils under citrus trees in central Florida and its effect upon penetration and the efficiency of irrigation. Soil Science Society of America Proceedings, 11: 103-109.

Jex, G.W., Bleakley, B.H., Hubbell, D.H., and Munro, L.L., 1985. High humidity-induced increase in water repellency in some sandy soils. Soil Science Society of America Journal, 49: $1177-1182$.

John, P.H., 1978. Heat-induced water repellency in some New Zealand pumice soils. New Zealand Journal of Science, 21: 401-407.

King, A.R., 1962. The efficiency of rural fire fighters. CSIRO Australian Chemical Research Laboratories Technical Paper no. 4, cited by Humphreys, F.R. and Craig, F.G., Effects of fire on soil chemical, structural and hydrological properties, In: Gill, A.M., Groves, R.H. and Noble, I.R. (Editors). Fire and the Australian Biota, Australian Academy of Science, 1981; pp. 177-200.

King, P.M., 1974. Water repellence - an assessment of past discovery and future research requirements. Internal publication (S26) of the South Australia Department of Agriculture.

King, P.M., 1981. Comparison of methods for measuring severity of water repellence of sandy soils and assessment of some factors that affect its measurement. Australian Journal of Soil Research, 19: 275-285.

Kleinbaum, D.G. and Kupper, L.L., 1978. Applied Regression Analysis and Other Multivariable Methods. Duxbury, North Scituate, Massachusetts, USA.

Knighton, M.D., 1977. Hydrologic response and nutrient concentration following spring burns in an oak-hickory forest. Soil Science Society of America Journal, 41: 627-632.

K.ozlowski, T.T. and Ahlgren, C.E., 1974. Fire and Ecosystems. Academic Press, New York.

Krammes, J.S. and DeBano, L.F., 1965. Soil wettability: a neglected factor in watershed management. Water Resources Research, 41: 283-286.

Krammes, J.S. and Osborn, J., 1969. Water-repellent soils and wetting agents as factors influencing erosion. In: DeBano, L.F., and Letey, J. (Editors). Proceedings Symposium, Water-repellent soils (May 1968, Riverside, California). University of California, Riverside, pp. 177-186.

Kusaka, S, Nakane,K and Mitsudera, M, 1983. Effect of fire on water and major nutrient budgets in forest ecosystems 1. Water balance. Japanese Journal of Ecology, 33: 323-332.

Lambrechts, J.J.N., Theron, A.A. and Fry, M., 1986. Detail characterization of soils under different fynbos-climate-geology combinations in South and Southwestern Cape. Project Report, Ecosystem Programmes, CSIR, Pretoria.

Langford K.J., 1976. Change in yield of water following a bushfire in a forest of Eucalyptus regnans. Journal of Hydrology, 29: 87-114. 
Leitch, C.J., Flinn, D.W. and van de Graaff, R.H.M., 1983. Erosion and nutrient loss resulting from Ash Wednesday (February 1983) wildfires: a case study. Australian Forestry, 46: $173-180$.

Letey, J., Osborn, J. and Pelishek, R.E., 1962. Measurement of liquid-solid contact angles in soil and sand. Soil Science, 93: 149-153.

Lindley, A.J., Bosch, J.M. and Van Wyk, D.B., 1988. Changes in water yield after fire in fynbos catchments. Water SA, 14: 7-12.

Lowdermilk, W.C., 1930. Influence of forest litter, run-off, percolation and erosion. Journal of Forestry, 28: 474-491.

Luke, R.H. and McArthur, A.G., 1977. Bushfires in Australia. Department of Primary Industry, Forestry and Timber Bureau, CSIRO Division of Forest Research. Australian Government Publishing Service, Canberra.

Mackay, S.M. and Cornish, P.M., 1982. Effects of wildfire and logging in the hydrology of small catchments near Eden, New South Wales. The First National Symposium on Forest Hydrology, May 1982, Melbourne, Australian Institution of Engineers. pp. 111-117.

McDonald, D.J., 1985. The plant communities of Swartboschkloof, Jonkershoek. South African Natural Scientific Programmes Report No. 104, CSIR, Pretoria.

McGhie, D.A., 1981. The contribution of the mallet hill surface to runoff and erosion in the Narrogin region of western Australia. Australian Journal of Soil Research, 18: 299-307.

McGhie, D.A., and Posner, A.M., 1980. Water repellence of a heavy textured Western Australian surface soil. Australian Journal of Soil Research, 18: 309-323.

McNabb, D.H., Gaweda, F., and Froelich, H.A., 1989. Infiltration, water repellency, and soil moisture content after broadcast burning a forest site in southwest Oregon. Journal of Soil and Water Conservation, 44: 87-90.

McPhee, P.J., Smithen, A.A., Venter, C.J., Hartmann, M.O. and Crosby, C.T., 1983. The South African rainfall simulator programme for assessing soil loss and run-off. Technical Report no. 119, Department of Environment Affairs, pp. 352-368.

Mersereau, R.C. and Dyrness, C.T., 1972. Accelerated mass wasting after logging and slash burning in western Oregon. Journal of Soil and Water Conservation, 27: 112-114.

Nänni, U.W., 1960. The immediate effects of veld-burning on streamflow in Cathedral Peak catchments. Journal of the South African Forestry Association, 34: 7-12.

Nänni, U.W., 1970. Trees, water and perspective. South African Forestry Journal, 75: 9-17.

Norton, B.E. and McGarrity, J.W., 1965. The effect of burning of native pasture on soil temperature in Northern New south Wales. Journal of the British Grassland Society, 20: 101-105.

O'Loughlin, E.M., Cheney, N.P. and Burns, J., 1982. The Bushrangers experiment: hydrological response of a eucalypt catchment to fire. Proceedings First National 
Symposium on Forest Hydrology, Melbourne, May 1982. Institution of Engineers Australia, National Conference Publication 82/6, Melbourne, pp. 132-138.

Osborn, J.F., Letey, J., DeBano, L.F., and Terry, E., 1967. Seed germination and establishment as affected by non-wettable soils and wetting agents. Ecology, 48: 494-497.

Osborn, J.F., Pelishek, R.E., Krammes, J.S. and Letey, J., 1964. Soil wettability as a factor in erodibility. Soil Science Society of America Proceedings, 28: 294-295.

Packham, D.R., 1970. Heat transfer above a small ground fire. Australian Forest Research 5: 18-24, cited by Humphreys, F.R. and Craig, F.G., Effects of fire on soil chemical, structural and hydrological properties, In: Gill, A.M., Groves, R.H. and Noble, I.R. (Editors). Fire and the Australian Biota. Australian Academy of Science, 1981; pp. 177-200.

Pase, C.P. and Ingebo, P.A., 1965. Burned chaparral to grass: early effects on water and sediment yields from two granitic soil watersheds in Arizona. Proceedings Annual Arizona Watershed Symposium, pp. 8-11.

Pearce, A.J., Stewart, M.K. and Sklash, M.G., 1986. Storm runoff generation in humid headwater catchments: 1 . Where does the water come from? Water Resources Research, 22: $12-1281$

Potts, D.F., Peterson, D.L. and Zuuring, H.R., 1989. Estimating postfire water production in the Pacific Northwest. USDA Forest Service, Research Paper PSW-197. Pacific Southwest Forest and Range Experiment Station, Berkeley, California.

Pritchett, W.L., 1979. Properties and Management of Forest Soils. John Wiley and Sons, New York.

Reeder, C.J., and Jurgensen, M.F., 1979. Fire-induced water repellency in forest soils of upper Michigan. Canadian Journal of Forestry Research, 9: 369-373.

Roberts, F.J., and Carbon, B.A., 1972. Water repellence in sandy soils of South-western Australia. Australian Journal of Soil Research, 10: 35-42.

Ronan, N.M., 1986. The hydrological effects of fuel reduction burning and wildfire at Wallaby Creek. Melbourne and Metropolitan Board of Works, Report No. MMBW-W-0015, Melbourne, Australia.

Rowe, P.B., Countryman, C.M. and Storey, H.C., 1954. Hydrologic analysis used to determine effects of fire on peak discharge and erosion rates in southern California watersheds. USDA Forest Service, California Forest and Range Experiment Station.

Rowe, P.B., Storey, H. and Hamilton, E.L., 1951. Some results of hydrologic research. In: Some aspects of watershed management in southern California. USDA Forest Service, California Forest and Range Experiment Station, Miscellaneous Paper 1, pp. 19-29.

Russell, W.B., 1983. Conservation of arable land in the USA: report on service tour. Unpublished report, Department of Agriculture and Fisheries, Natal Region, Cedara, South Africa. 
Ruyten, E.C.W.M., and de Goede-Hiensch, E.W.A., (Editors), 1988. Jaarverslag 1987 Stichting voor Bodemkartering. Wageningen, Stichting voor Bodemkartering.

Rycroft, H.B., 1947. A note on the immediate effects of veld burning on storm-flow in a Jonkershoek catchment. Journal of South African Forestry Association, 15: 80-85.

Salih, M.S.A., Taha, F.K.H. and Payne, G.F., 1973. Water repellency of soils under burned sagebrush. Journal of Range Management, 26: 330-331.

SAS Institute, 1985. SAS Users Guide: Statistics, Version 5 Edition. SAS Institute, Cary, North Carolina, USA.

Savage, S.M., 1974. Mechanism of fire-induced water repellency in soil. Soil Science Society of America Proceedings, 38, 652-657.

Savage, S.M., Martin, J.P., and Letey, J., 1969. Contribution of some soil fungi to natural and heat-induced water repellency in sand. Soil Science Society of America Proceedings, 33: $405-409$.

Savage, S.M., Osborn, J., Letey, J. and Heaton, C., 1972. Substances contributing to fireinduced water repellency in soils. Soil Science Society of America Proceedings, 36: 674678.

Savage, M.J., and Vermeulen, K., 1983. Microclimate modification of tall moist grasslands of Natal by spring burning. Journal of Range Management, 36: 172-174.

Schmidt, E.J., 1989. Simulation of sediment yield. In: Schulze, R.E., (Editor). ACRU: Background, Concepts and Theory. Agricultural Catchments Research Unit Report 35, 1989. Department of Agricultural Engineering, University of Natal, Pietermaritzburg, RSA. Chapter 11.

Schmidt, E.J. and Schulze, R.E., 1989. The Dehoek/Ntabamhlope hydrological catchments 1974 to 1989. Department of Agricultural Engineering, University of Natal, Pietermaritzburg, RSA, Agricultural Catchments Research Unit Report No. 33, May 1989.

Schulze, R.E., 1984. Hydrological models for application to small rural catchments in southern Africa: Refinements and development. Water Research Commission report $63 / 2 / 84$. Water Research Commission, Pretoria.

Schulze, R.E., 1989a. (Editor). ACRU: Background, Concepts and Theory. Agricultural Catchments Research Unit Report 35, 1989. Department of Agricultural Engineering, University of Natal, Pietermaritzburg, RSA.

Schulze, R.E., 1989b. Simulation of streamflow. In: Schulze, R.E., (Editor). ACRU: Background, Concepts and Theory. Agricultural Catchments Research Unit Report 35, 1989. Department of Agricultural Engineering, University of Natal, Pietermaritzburg, RSA. Chapter 8.

Scholl, D.G., 1971. Soil wettability in Utah juniper stands. Soil Science Society of America Proceedings, 35: 344-345. 
USDA, 1972. National Engineers Handbook, Section 4, Hydrology. USDA Soil Conservation Service. Government Printers Office, Washington DC, USA.

Van Dam, J.C., Hendrickx, J.M.H., Van Ommen, H.C., Bannink, M.H., Van Genuchten, M.Th. and Dekker, L.W., 1990. Water and solute movement in a coarse-textured waterrepellent field soil. Journal of Hydrology, 120: 359-379.

Van der Zel, D.W. and Kruger, F.J., 1975. Results of the multiple catchment experiments at the Jonkershoek research station, South Africa. 2. Influence of protection of fynbos on stream discharge in Langrivier. Forestry in South Africa, 16: 13-18.

Van Lear, D.H., Douglass, J.E., Cox, S.K. and Augspurger, M.K., 1985. Sediment and nutrient export in runoff from burned and harvested pine watersheds in the South Carolina Piedmont. Journal Environmental Quality, 14: 169-174.

Van Lill, W.S., Kruger, F.J. and Van Wyk, D.B., 1980. The effect of afforestation with Eucalyptus grandis ex Maiden and Pinus patula Schlecht. et Cham. on streamflow from experimental catchments at Mokobulaan, Transvaal. Journal of Hydrology, 48: 107-118.

Van Wagner, C.E., 1972. Duff consumption by fire in eastern pine stands. Canadian Journal of Forest Research, 2: 34-39.

Van Wijk, W.R. and De Vries, D.A., 1963. Periodic temperature variations in a homogeneous soil. In: Van Wijk, W.R. (Editor). Physics of the Plant Environment pp. 102-143. North Holland Publishing Company, Amsterdam.

Van Wilgen, B.W., Richardson, D.M., Kruger, F.J. and Van Hensbergen, H.J., (Editors) 1992. Fire in South African Mountain Fynbos: ecosystem, community and species response at Swartboskloof. Ecological Series no. 93, Springer, Heidelberg.

Van Wyk, D.B., 1977. Die invloed van bebossing met Pinus radiata op die totale jaarlikse afvoer van die Jonkershoek strome. Unpublished M.Sc. thesis, University of Stellenbosch.

Van Wyk, D.B., 1982. Influences of prescribed burning on nutrient budgets of mountain fynbos catchments in the S.W. Cape, Republic of South Africa. In: Proceedings of the Symposium on Environmental Consequences of Fire and Fuel Management in Mediterranean-type Ecosystems, June 1981, San Diego, California. USDA Forest Service, General Technical Report PSW-58. Pacific Southwest Forest and Range Experiment Station, Berkeley, California.

Van Wyk, D.B., 1983. Apparatus for sampling of streams for chemical quality and sediment. Water SA, 9: 88-92.

Van Wyk, D.B., 1986. The effects of catchment management on sediment and nutrient exports in the Natal Drakensberg. In: Schulze, R.E. (Editor.), Proceedings second South African National Hydrology Symposium, Pietermaritzburg, Sept. 1985, Agricultural Catchments Research Unit Report No. 22, p. 266-274.

Van Wyk, D.B., 1987. Some effects of afforestation on streamflow in the Western Cape Province, South Africa. Water SA, 13: 31-36. 
Scholl, D.G., 1975. Soil wettability and fire in Arizona chaparral. Soil Science Society America Proceedings, 39: 356-361.

Scott, D.F. and Van Wyk, D.B., 1990. The effects of wildfire on soil wettability and hydrological behaviour of an afforested catchment. Journal of Hydrology, 121: 239-256.

Scott, D.F. and Van Wyk, D.B. 1992. Chapter 12: The effects of fire on soil water repellency, catchment sediment yields and streamflow. In: Van Wilgen, B.W., Richardson, D.M., Kruger, F.J. and van Hensbergen, H.J. (Editors). Fire in South African Mountain Fynbos: ecosystem, community and species response at Swartboskloof. Ecological Series no. 93, Springer, Heidelberg.

Scott, J.D., 1951. A contribution to the study of the problems of the Drakensberg conservation area. Science Bulletin no. 324, Union of South Africa, Department of Agriculture.

Scott, V.H. and Burgy, R.H., 1955. Effects of heat and brush burning on the physical properties of certain upland soils that influence infiltration. Soil Science, 82: 63-70.

Scotter, D.R., 1970. Soil temperatures under grass fires. Australian Journal of Soil Research 8: 273-279.

Sinclair, J.D., 1954. Erosion in the San Gabriel Mountains of California. Transactions of the American Geophysical Union, 35: 264-268.

Singer, M.J., and Ugolini, F.C., 1976. Hydrophobicity in the soils of Findley Lake, Washington. Forest Science, 22: 54-58.

Smith, R.M. and Stamey, W.L., 1965. Determining the range of tolerable erosion. Soil Science, 100: 414-424.

Söhnge, A.P.G., 1988. The geology of Swartboskloof. South African Forestry Research Institute, Report J3/88, Jonkershoek Forestry Research Centre, Stellenbosch.

Steel, R.G.D. and Torrie, J.H., 1960. Principles and Procedures of Statistics. McGraw-Hill, New York.

Swanson, N.P., 1965. Rotating-boom rainfall simulator. Transactions of the American Society of Agricultural Engineers, 8: 71-72.

Teramura, A.H., 1980. Relationship between stand age and water repellency of chaparral soils. Bulletin of the Torrey Botanical Club, 107: 42-46.

Tiedemann, A.R., Conrad, C.E., Dieterich, J.H., Hornbeck, J.W., Megahan, W.F., Viereck, L.A. and Wade, D.D., 1979. Effects of Fire on Water: a state of knowledge review. USDA Forest Service, General Technical Report WP-10, Washington DC, USA.

Tillman, R.W., Scotter, D.R., Wallis, M.G. and Clothier, B.E., 1989. Water-repellency and its measurement by using intrinsic sorptivity. Australian Journal of Soil Research, 27: 637-644. 
Van Wyk, D.B., and Lesch, W., 1989. The effect of the Langrivier fire on water quality and sediment yield. In: Richardson, D.M. (Editor). The short-term effects of fire in Langrivier, Jonkershoek State Forest, Stelleribosch. South African Forestry Research Institute Report J.2/89, Jonkershoek Forestry Research Centre, Stellenbosch. p. 78-88.

Van't Woudt, B.D., 1959. Particle coatings affecting the wettability of soils. Journal of Geophysical Research, 64: 263-267.

Versfeld, D.B., 1981. Overland flow on small plots at Jonkershoek Forestry Research Station. South African Forestry Journal, 119, 35-40.

Ward, R.C., 1975. Principles of Hydrology. Second edition. McGraw-Hill, London.

Watson, C.L. and Letey, J., 1970. Indices for characterizing soil-water repellency based upon contact angle - surface tension relationships. Soil Science Society of America Proceedings, $34: 841-844$.

Watson, H.K. and Poulter, A., 1987. Erodibility of soils at Cathedral Peak in the Natal Drakensberg. Unpublished poster paper presented at the symposium "50 years of research in mountain catchments in South Africa ". November 1987, Stellenbosch.

Wells, C.G., Campbell, R.E., DeBano, L.F., Lewis, C.E., Frederiksen, R.L., Franklin, E.C., Froelich, R.C. and Dunn, P.H., 1979. Effects of Fire on Water: a state of knowledge review. USDA Forest Service, General Technical Report WP-7, Washington DC, USA.

Wicht, C.L., Meyburgh, J.C. and Boustead, P.G., 1969. Rainfall at the Jonkershoek Forest Hydrological Research Station. Annale, Universiteit van Stellenbosch, Vol. 44, Serie 1, nr. 1. University of Stellenbosch, Stellenbosch, South Africa. 